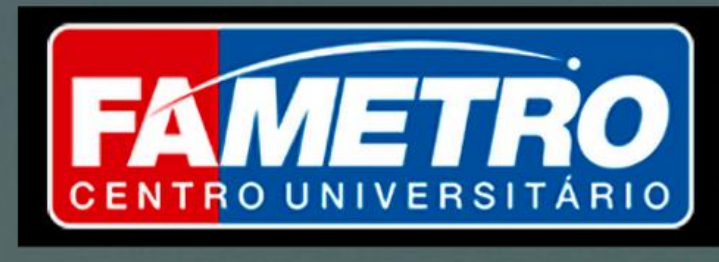

A Saúde Mental em Discussão

\title{
ORGANIZADORES
}

JULIO CESAR PINTO DE SOUZA DIEGO RAFAEL CUNHA CAVALCANTE

SUELÂNIA CRISTINA GONZAGA DE FIGUEIREDO
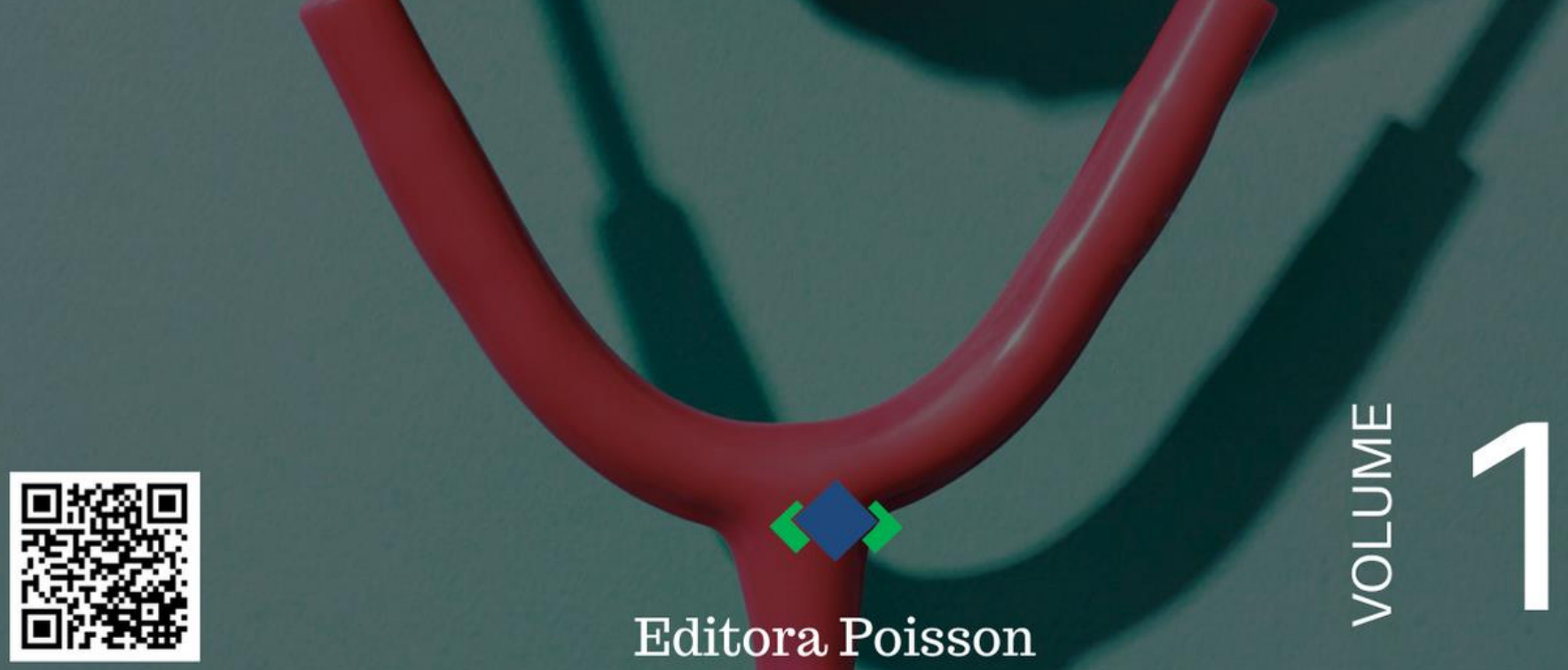
Julio Cesar Pinto de Souza

Diego Rafael Cunha Cavalcante

Suelânia Cristina Gonzaga de Figueiredo

(Organizadores)

\section{A saúde mental em discussão Volume 1}

1a Edição

Belo Horizonte

Poisson

2021 


\section{Editor Chefe: Dr. Darly Fernando Andrade}

\section{Conselho Editorial}

Dr. Antônio Artur de Souza - Universidade Federal de Minas Gerais

Ms. Davilson Eduardo Andrade

Dra. Elizângela de Jesus Oliveira - Universidade Federal do Amazonas

Msc. Fabiane dos Santos

Dr. José Eduardo Ferreira Lopes - Universidade Federal de Uberlândia

Dr. Otaviano Francisco Neves - Pontifícia Universidade Católica de Minas Gerais

Dr. Luiz Cláudio de Lima - Universidade FUMEC

Dr. Nelson Ferreira Filho - Faculdades Kennedy

Ms. Valdiney Alves de Oliveira - Universidade Federal de Uberlândia

Dados Internacionais de Catalogação na Publicação (CIP)

S255
A saúde mental em discussão - Volume $1-$
Organização: Julio Cesar Pinto de Souza
Diego Rafael Cunha Cavalcante, Suelânia
Cristina Gonzaga de Figueiredo, Belo
Horizonte - MG: Poisson, 2021
Formato: PDF
ISBN: 978-65-5866-086-6
DOI: 10.36229/978-65-5866-086-6
Modo de acesso: World Wide Web
Inclui bibliografia
1. Saúde Mental 2. Psicologia I. Souza,
Julio Cesar Pinto II.Cavalcante, Diego Rafael
Cunha III.Figueiredo, Suelânia Cristina
Gonzaga de IV. Título

O conteúdo deste livro está licenciado sob a Licença de Atribuição Creative Commons 4.0.

Com ela é permitido compartilhar o livro, devendo ser dado o devido crédito, não podendo ser utilizado para fins comerciais e nem ser alterada.

O conteúdo dos artigos e seus dados em sua forma, correção e confiabilidade são de responsabilidade exclusiva dos seus respectivos autores

www.poisson.com.br contato@poisson.com.br 


\section{Comissão organizadora}

\section{Julio Cesar Pinto de Souza}

Graduado em psicologia clinica pela Universidade Federal do Amazonas (UFAM), especialista em psicologia do esporte (Faculdades Integradas-Brasília/DF) e Mestre em psicologia (linha psicossocial) pela UFAM. Também possui especializações nas seguintes áreas: Gestão com ênfase em Administração Hospitalar (FGV-RJ) e Relações Públicas e especialidades de marketing (UVA-RJ). Participante do grupo de pesquisa Psicologia e práticas socioculturais da UFAM. Parecerista da Revista Psicologia e Saúde. Atuação na área da Assistência Social e professor de graduação e pós-graduação. Atualmente professor do Instituto Metropolitano de Ensino - IME.

\section{Diego Rafael Cunha Cavalcante}

Possui graduação em Psicologia pelo Centro Universitário Luterano de Manaus, pósgraduado em Psicologia Organizacional e em MBA em Gestão de Pessoas por Competências. Tem experiência na área de Psicologia, com ênfase em Psicologia Organizacional, T\&D, Remuneração \& Benefícios, assim como em Psicologia Experimental e Pesquisas. Docente do Ensino Superior em Psicologia desde 2010. Atualmente docente do Instituto Metropolitano de Ensino- IME.

\section{Suelânia Cristina Gonzaga de Figueiredo}

Possui graduação em Economia, mestrado em Desenvolvimento Regional e doutorado em Ciências da Educação. Atualmente é Coordenadora de Pesquisa e Extensão do Instituto Metropolitano de Ensino-IME, atuando principalmente nos seguintes temas: Sustentabilidade, Pesquisa, Iniciação Cientifica, Articulação entre Pesquisa, Ensino e Extensão. Autora do Projeto Produzir e Publicar. 


\title{
Prefácio
}

O homem, por sua natureza e desde os primórdios, sempre buscou um meio de explicar os fenômenos que ocorrem a sua volta, seja por um motivo sobrenatural ou divino ou de forma sistemática, cientifica, racional.

Na história da humanidade podemos perceber que as sociedades deram grandes saltos evolutivos através do estudo sistemático e da ciência, o qual podemos citar desde a invenção do calendário e sua grande contribuição para a sociedade agrícola, a invenção da máquina a vapor para a revolução industrial, até a invenção da inteligência artificial nos tempos mais recentes.

Naturalmente todos nós nascemos com alto grau de curiosidade sobre o mundo que nos cerca, e o papel da academia nesse contexto é o de sistematizar e estruturar essa curiosidade a tal ponto que se produza um novo saber, conhecimento, sob a realidade vivida.

Diante do exposto percebe-se o nível de importância da ciência para a sociedade, fazendo novas descobertas e encontrando novos caminhos, quando estamos a mercê de grandes catástrofes ou de situações que ameacem a continuidade da espécie humana.

Na modernidade, a academia ou ensino superior é o local primário em que se aprende e se inicia a pesquisa cientifica, que se produz conhecimento para que as gerações subsequentes possam ter melhores respostas aos problemas sociais ou ainda para ter uma melhor qualidade de vida, tanto na esfera individual quanto na esfera coletiva.

Um dos alicerces do ensino superior é a pesquisa, e o Centro Universitário FAMETRO vem buscando, com o tempo, fomentar e intensificar a pesquisa cientifica e consequentemente a publicação por parte do seu quadro docente e discente, buscando através destas devolver a sociedade benefícios e conhecimento oriundas destas produções.

Neste caderno cientifico, constam monografias selecionadas em termos de qualidade técnica e relevância social entre os alunos finalistas de 2020/2 e sob orientação e tutela do Professor Mestre Júlio César Pinto de Souza, versando sobre diversas temáticas, tais como: Luto, Gênero, Saúde Mental, Psicologia Social, Psicologia do Esporte, Arteterapia, entre outros.

\author{
Diego Rafael Cunha Cavalcante \\ Coordenador do curso de psicologia do Centro Universitário FAMETRO
}




\section{SUMÁRIO}

Capítulo 1: Luto parental em situação de perda repentina: Perda do filho 08

Adryana Mara da Silva Nascimento

DOI: 10.36229/978-65-5866-086-6.CAP.01

Capítulo 2: A condição de gênero como fator para o sofrimento psíquico em mulheres e a psicologia feminista

Ana Thayná de Matos Simplicio

DOI: 10.36229/978-65-5866-086-6.CAP.02

Capítulo 3: 0 suicídio e os fatores de risco em adolescentes

Antônia Batista Mendes de Sá

DOI: 10.36229/978-65-5866-086-6.CAP.03

Capítulo 4: As causas que levam a depressão em idosos que são abandonados pela família em instituições de longa permanência. 73

Brenda Stefany Pereira

DOI: 10.36229/978-65-5866-086-6.CAP.04

Capítulo 5: 0 uso dos mecanismos psicológicos na influência de escolha do consumidor 88

Gabriela Brito Cavalcante

DOI: 10.36229/978-65-5866-086-6.CAP.05

Capítulo 6: A contribuição da psicologia do esporte para a qualidade de vida do idoso

Gíbia Ribeiro Messias

DOI: 10.36229/978-65-5866-086-6.CAP.06

Capítulo 7: 0 homem e a ocupação: Uma discussão acerca da relação do homem com o trabalho. 


\section{SUMÁRIO}

Capítulo 8: 0 sofrimento e a superação a partir de um estudo de caso das experiências de Alexander Sozhenitsyn e Viktor Frankl

Matheus de Sá Moraes

DOI: 10.36229/978-65-5866-086-6.CAP.08

Capítulo 9: Análise psicológica da saúde mental de professores da rede pública de ensino

Paulo Melo Bernardes

DOI: 10.36229/978-65-5866-086-6.CAP.09

Capítulo 10: Arteterapia na esquizofrenia um estudo de caso 167

Daynara Souza Aparício

DOI: 10.36229/978-65-5866-086-6.CAP.10 


\section{Capítulo 1}

\section{Luto parental em situação de perda repentina: Perda do filho}

\section{Adryana Mara da Silva Nascimento}

Resumo: 0 presente trabalho visa abordar a questão do luto pela morte de um filho, quando ocorre de forma inesperada e acidental. Pessoas ao longo de suas vidas vivenciam diferentes situações de perda, que levam a um processo chamado luto, que pode ser devido à perda de um objeto, fases da vida, afetos, a morte de um ente querido, entre outros. 0 objetivo geral do presente trabalho é discutir acerca dos impactos psicológicos que acometem os pais com o luto de um filho. Para atingir aos objetivos, recorreu-se à pesquisa bibliográfica. Os resultados apontam que o luto pela perda de um filho como uma das perdas mais dolorosas e difíceis para os pais. 0 processo de luto pode ser realizado em formas diferentes, onde todas as dimensões estarão envolvidas, dependendo do vínculo estabelecido, também do indivíduo, família e do ambiente sociocultural do mesmo. Conclui-se que os pais podem experimentar diferentes sentimentos e experiências quando seu filho falece. Alguns deles podem ser conflitos familiares decorrentes de diferentes pontos de vista sobre como lidar com o luto (há quem queira falar sobre isso e quem prefira não falar). As sensações físicas temporárias associadas à fase de luto também podem se manifestar, a partir de: distúrbios do sono, fadiga, falta de energia, hipersensibilidade a ruídos ou sensação de aperto na garganta e no peito. Da mesma forma, as emoções que podem surgir temporariamente quando um filho morre são variadas e pessoais. Alguns deles podem ser: tristeza, culpa, raiva, bloqueio, ansiedade ou insensibilidade.

Palavras-chave: Luto; Morte; Psicologia. 


\section{INTRODUÇÃO}

O ser humano, ao nascer, chega ao mundo inserido dentro de um núcleo familiar, contexto onde se irá crescer atrelado ao convívio com entes familiares queridos e aprender-se-á referenciais, valores, sentimentos de amor, união e todos os alicerces necessários para ser homens e mulheres de bem. Perspectiva esta que norteia toda uma vida, sem ceder lugar para sentimentos ou premissas de falta ou perda de qualquer uma destas condições.

A morte de um filho de qualquer idade é uma experiência profunda, difícil e dolorosa. Embora o luto seja estressante sempre que ocorre, os estudos continuam a fornecer evidências de que o maior estresse, e frequentemente o mais duradouro, ocorre para pais que experimentam a morte de um filho (FRANQUEIRA et al., 2015).

Indivíduos e famílias têm muitas capacidades e habilidades que lhes permitem responder à perda interpessoal e emergir da experiência mudada, mas não quebrada. Os poucos estudos que compararam respostas a diferentes tipos de perdas descobriram que a perda de um filho é seguida por um sofrimento mais intenso do que a morte de um cônjuge ou pai. Essa conclusão deve ser considerada com cautela, no entanto, uma vez que esses estudos geralmente confundem as diferenças amostrais em idade e grau de aviso prévio (COELHO FILHO; LIMA, 2017).

A informação é importante porque, de acordo com Gomes et al. (2015), cerca de metade das mortes de crianças ocorrem durante a infância, a maioria com tempo de preparação limitado. Lesões não intencionais são a principal causa de morte em crianças de 1 a 14 anos e representam mais da metade de todas as mortes entre jovens de 15 a 19 anos de idade. Além disso, embora a taxa de mortalidade geral de crianças com 14 anos ou menos tenha diminuído substancialmente desde a década de 1950, as taxas de homicídio infantil triplicaram e as taxas de suicídio quadruplicaram. Achados recentes sugerem que os pais de crianças que morrem por qualquer causa têm mais probabilidade de sofrer sintomas de estresse traumático e experimentam problemas mais graves com desregulação emocional do que ocorre com a morte de um cônjuge.

Gomes et al. (2015) mencionam que em contraste com o passado em que as famílias poderiam ter vários filhos morrendo, a morte na infância agora é rara. As crianças devem viver até a idade adulta. Em conflito com as expectativas atuais do ciclo de vida, a morte de uma criança pode ser experimentada como a morte dos sonhos futuros dos pais, além de criar uma mudança profunda em seus papéis e funcionamento atuais. Aumentos na incidência de suicídio e homicídio em adolescentes e atos aleatórios de violência em nossa sociedade aumentaram o risco de respostas traumáticas ao estresse de familiares enlutados.

Os avanços médicos prolongaram o processo de morte de crianças e adultos, tornando a doença terminal em crianças mais longa e mais complexa, exigindo frequentemente que os pais tomem decisões difíceis sobre os cuidados no final da vida. Evidências preliminares de pesquisa sugerem que o luto familiar pode ser afetado negativamente pela incapacidade de reduzir o sofrimento durante o processo de morte da criança (FRANQUEIRA et al., 2015).

0 interesse pela temática partiu da inquietação da autora em verificar respostas ou embasamentos que apresentem como ocorre o luto em pais que perderam seus filhos de forma repentina, a fim de enriquecer a proposta ora apresentada e sem que se incorra em temas geralmente repetitivos. Embora o luto seja uma reação natural para muitos pais, os psicólogos fornecem estratégias para administrar e até superar a dor.

A relevância desta pesquisa é incentivar o olhar humanizador e acolhedor que é tão necessário aos profissionais que estão envolvidos com o processo do luto e dos parentes que precisam lidar com as frustrações, medo, culpa, tristeza, angústia, dentre outros. É com este propósito que se propõe a temática para referida pesquisa que foi fortalecida ao longo de sua construção. E, diante de todo o exposto e a busca constante do entendimento, que caminho trilhar para encontrar respostas a respeito do impacto luto parental em perdas repentinas. Desta forma, a relevância da pesquisa consiste em apresentar uma temática atual que possa servir como base para trabalhos futuros.

0 objetivo geral do presente trabalho foi discutir acerca dos impactos psicológicos que acometem os pais com o luto de um filho. Já os objetivos específicos foram: a. Identificar sentimentos que envolvem o luto dos pais na perda de um filho; b. Estudar consequências psicossociais de pais enlutados; c. Evidenciar a importância do psicólogo para o processo de luto que os pais enfrentam após a perda de um filho.

O primeiro capítulo aborda o referencial teórico, apontando os antecedentes históricos: morte e sofrimento, trauma, experiência extrema, perda-luto e o papel e a perda dos pais de uma criança. No 
segundo capítulo apresenta-se a trajetória metodológica da pesquisa bibliográfica realizada para atingir aos objetivos propostos. 0 capítulo III destaca a discussão, com tópicos que descrevem os sentimentos que envolvem o luto dos pais na perda de um filho, consequências psicossociais de pais enlutados, importância do psicólogo para o processo de luto que os pais enfrentam após a perda de um filho.

\section{REFERENCIAL TEÓRICO}

\section{Antecedentes históricos: morte e sofrimento}

O ser humano desde o início de sua vida, deve conviver tanto com o fato de sua própria morte, como a das pessoas com quem manterá um vínculo afetivo. A morte, conforme expressa Bacci (2017, p. 1), "refere-se a um conceito culturalmente e socialmente construído". Isso se refere à existência em diferentes culturas de eventos como luto, permitindo que as pessoas processem e desenvolvam sua própria morte, bem como a de outros membros da sociedade.

Para o autor Cabodevilla (2017), a forma de compreender o processo de luto será ligada à forma como a morte é tratada na cultura a que a pessoa pertence, e mudou de acordo com os diferentes tempos que o ser humano passou. Este pode ser reafirmado nas contribuições do autor Bacci, ao afirmar que "a consciência de morte e a necessidade de ritualização típica de nossa espécie aparecem com o Homo Sapiens que pintavam seus mortos e os adoravam com objetos" (BACCI, 2017, p.2).

É importante destacar as pesquisas realizadas sobre a forma como o homem tem lidado com o tema da morte em diferentes épocas, como a realizada pelo autor Ariés (2015), que em seu estudo mostra as diferentes formas como as pessoas estão relacionados à morte. Este estudo mostra as mudanças que ocorreram produzidas ao longo da história em relação aos modos de enfrentar a morte, bem como também ritos fúnebres e luto.

Ariés (2015) faz uma viagem por diferentes épocas, a primeira delas desde o século VI a XII; que ele chama de morte domesticada, desde a morte de pessoas que ocorreram em casa, em sua cama, com sua família e o moribundo que estava se aproximando, ele poderia providenciar os preparativos para o funeral dela, como também informar a família de seus desejos. Como a morte ocorreu no campo doméstico, os cerimoniais realizados eram públicos, onde os moribundos recebiam em sua cama amigos e familiares, entre outros e foi baseada na aceitação em si.

Do século XII até o final do século XVI, devido à preponderância das concepções religiosas, começa a preocupação com a própria morte, dando-lhe um sentido dramático, já que a morte seria o fim da vida e uma provação teria que ser enfrentada no final. Ao chegar ao século XVII ainda sob a influência da religião, começaram a tentar se redimir dos pecados, tentações terrenas, e o religioso passa a configurar o que são cerimônias e rituais, onde quem morre já não se expõe no seio da família, mas que devido à decomposição do corpo tais rituais e cerimônias são realizados, tirando-o de sua casa.

Então, no século XVIII, com a época do romantismo, preocupa-se com a morte do outro, de um ente querido, garantindo-se uma parte do drama. Também no final deste século a morte não é mais investida apenas pelo reino do que religioso, para se tornar um assunto médico. No século XIX, o avanço da medicina em relação à saúde e à doença, permite a existência de curas para doenças que antes destruíam populações. Isso abre caminho para o que expressou como "regulamentação médica sobrea vida e a morte optarão pelo modelo médico hegemônico da sociedade ocidental "(BACCI, 2017, p.3).

Com todas as mudanças que ocorreram neste momento, também há mudanças na relação com a morte, onde os rituais são carregados de emoção, choro e dor, conflitos que não permitem a aceitação da morte pelos familiares. Com o passar do século XX, a morte começa a ser rejeitada, escondida, não mais o moribundo recebe o lugar que ocupou nos séculos anteriores, onde soube de sua morte se preparando para o seu fim, e se a morte veio sem aviso prévio, então inesperado, foi considerado um mau presságio. Os rituais deixaram de ser feitos envolvendo a comunidade e a família; dando origem neste século a uma vida muito mais individual, em que predomine o silêncio e é melhor que as pessoas que vão morrer não saibam.

A morte na hipermodernidade é considerada por Ariés (2015) como morte dos excluídos. Isso traz consigo muita angústia e surgem dificuldades na forma de manejá-la, como na aceitação dela, e isso ocorre em relação à própria morte, como no de entes queridos, mesmo negando-a. Esta morte excluída moveu o morrer para a instituição Hospitalar, onde com base em tratamentos médicos e cuidados paliativos visam evitar a morte e, se possível, busca-se um prolongamento da vida. 
Expressões de dor em público por parte dos enlutados não são mais malvadas e nem chorar. Por isso, o luto é solitário e se torna um processo doloroso, mas rápido de resolver. Bacci (2017) levanta uma necessidade por parte das pessoas que iniciam um luto, para recorrer a assistência médica e psicológica, para lidar com o curso de sua dor, acrescentando: O luto hoje é uma doença insuportável que deve ser curada o mais rápido possível e terapias são exigidas para controlar ou eliminar a dor produzida pela morte. Não é mais uma peculiaridade humana, o sofrimento devido ao desaparecimento do sujeito amado, que deve ser o tempo.

Desde o nascimento, o ser humano como ser social está em permanente contato com outros seres humanos, formando laços afetivos que serão de extrema importância durante o curso de sua vida. A perda de um ente querido, como a morte de um filho, pode ser muito difícil aceitar para quem sofre e ainda mais quando ocorre de modo abrupto, onde as circunstâncias que o cercam são imprevistas e dolorosas; ser experiências que ocorrem de forma incontrolável, portanto, podem levar a este fato vivenciado como traumático.

\section{Trauma}

Conforme afirma Echeburúa (2019, p. 24), um trauma produz um "desconforto intenso derivado de um evento negativo, abrupto e inesperado, com consequências dramáticas e foi causado por outros seres humanos". Esses eventos excedem a capacidade de resposta do sujeito, onde se sente oprimido, superado diante dessas situações inesperadas que implicam um reajuste, um repensar uma situação de perda que perturba a realidade.

Complementando o que já foi dito por Echeburúa, Sales (2015, p. 37) faz uma definição mais ampla e entende por Trauma:

a) uma experiência que constitui uma ameaça à integridade física ou psicológica da pessoa, muitas vezes associado a emoções ou experiências de caos e confusão durante o evento, fragmentação da memória, horror, ambivalência ou perplexidade; b) que tem, geralmente um caráter indizível, incontável e percebido como muitas vezes incompreensível para os outros; c) que quebra uma ou mais das premissas básicas que constituem as referentes à segurança humana e muito especialmente as crenças de invulnerabilidade e controle sobre a própria vida, confiança nos outros, em bondade e sua predisposição para a empatia e confiança no caráter controlável e previsível do mundo; d) que questiona os esquemas do self na frente do mundo e, portanto, a estrutura pessoal. De uma perspectiva étnica e intercultural, um fato traumático é aquele que gera uma ruptura do sistema de equilíbrios que regulam as vidas das pessoas e das pessoas em seu meio.

É extremamente importante considerar como o trauma afeta a realidade da pessoa que sofre, esta experiência tendo consequências extremas na visão do mundo, em relação às mudanças e estas envolvem tanto impactos negativos quanto os impactos positivos. Em relação ao impacto do trauma, é necessário ter em mente que experiências extremas afetam a percepção que uma pessoa tem do mundo e de nós. É um modo complexo e multidimensional, e é essencial ter ferramentas que permitem estabelecer certas tipologias, respondem à pragmática do poder orientar a ação terapêutica, individual ou coletiva, sobre estes (SALES, 2015).

É necessário ter em mente que em certas circunstâncias, como a morte de um ente querido, certos sentimentos e desejos começam a ser repensados, apresentando um questionamento, onde as pessoas podem conhecer facetas e pensamentos de si mesmo previamente desconhecidos, sendo necessário que eles o conheçam e explorem o que os constitui como tais e como eles agirão em certas situações adversas. Para isso, é importante levar em consideração o conceito de identidade, pois é definido como a visão que se tem de si mesmo e a maneira como entendemos o mundo e os fatos que nos cercam, pode ser considerada uma subcategoria das premissas ou prioris noções básicas sobre o mundo. Como estes, reflete uma forma difusa, dinâmica e dialógica de si mesmo em relação aos outros (SALES, 2015). 


\section{Experiência extrema}

Sales (2015) sugere que uma experiência extrema é concebida como uma experiência de trauma, onde há um perigo significativo para a integridade psicológica e física da pessoa; também pode ser uma perda traumática e inesperada de alguém com quem houve um vínculo emocional ou uma crise, que envolve a adaptação a mudanças significativas no contexto do ciclo de vida. Isso permite um questionamento da pessoa sobre sua realidade e seu ambiente.

Em relação ao exposto, a superação de um trauma é possível, segundo Echeburúa (2019), graças à capacidade inata de adaptação com a qual o indivíduo já conta com o desejo de superação que vai além dos contratempos que eles vêm até você na vida cotidiana. Seria então essencial adquirir habilidades de sobrevivência que lhe permite enfrentar e superar situações estressantes. Essas habilidades são adquiridas durante o processo de socialização, onde cada pessoa aprenda e cresça com cada situação vivida.

Por outro lado, outras pessoas não são capazes de enfrentar situações de estresse e angústia, sendo afetado a longo prazo, não ser capaz de elaborar uma perda e continuar vivendo com dor. É necessário enfatizar que o impacto de uma situação extrema será uma consequência ou resultado da interação entre a pessoa e o ambiente familiar, social e cultural, no que é produzido (SALES, 2015).

\section{Perda-luto}

Segundo Frizzo et al. (2017), qualquer perda levará ao luto, mas a intensidade disso não vai depender do objeto perdido, mas da carga afetiva que se investe, do valor que é dado ao objeto. É possível pensar que o luto não é apenas produzido pela morte de uma pessoa, mas envolve todos os tipos de perdas significativas. 0 referido autor expõe alguns deles como: perda de vidas, de aspectos dele mesmo, objetos externos, como o tipo material, perdas emocionais como perder amizades por exemplo e perdas relacionadas ao desenvolvimento; e adiciona isso sempre que houver uma perda, haverá um processo de luto. A perda é um tipo de trauma que, por sua vez, leva a um processo de luto. É considerada uma reação normal à perda ou separação de um ser querido, onde há dor e aborrecimento, bem como tristeza e dor.

É necessário para a elaboração de um processo de luto por ter tido vínculo com a pessoa perdida afetiva, conforme afirma Tizón (2019, p. 19), luto é um termo que em "nossa cultura costuma referir-se ao conjunto de processos psicológicos e psicossociais que seguem a perda de uma pessoa com quem o sujeito enlutado, o devedor, estava psicossocialmente ligado".

Luto é um termo amplo que abrange toda a experiência de familiares e amigos na antecipação, morte e subsequente adaptação à vida após a morte de um ente querido. É amplamente reconhecido como um processo complexo e dinâmico que não necessariamente se processa de maneira linear e ordenada. Em vez disso, os indivíduos têm reações simultâneas e sobrepostas que podem ocorrer a qualquer momento durante o processo de luto da família. O luto inclui a adaptação interna de cada membro da família; seus processos de luto, expressões e experiências de luto; e mudanças em seus arranjos de vida externos, relacionamentos e circunstâncias (LANÇA et al., 2017).

Luto é um termo que se refere ao conjunto mais específico e complexo de dificuldades cognitivas, emocionais e sociais que se seguem à morte de um ente querido. Os indivíduos variam enormemente no tipo de sofrimento que experimentam, sua intensidade, duração e sua maneira de expressá-lo. 0 luto é frequentemente definido como o processo interno de adaptação do indivíduo à perda de um ente querido ou como os modos socialmente prescritos de responder à perda, incluindo sua expressão externa em comportamentos como rituais e memoriais. Tomados em conjunto, os processos de luto e luto são entendidos como uma parte normal e universal do processo de cura natural que permite que indivíduos, famílias e comunidades convivam com a realidade da perda enquanto continuam vivendo (CREPALDI et al., 2020).

O luto complicado em adultos refere-se ao luto acompanhado por sintomas de sofrimento e trauma de separação. É definido como ocorrendo após uma morte que não seria objetivamente considerada "traumática" (isto é, não resultante de um evento imprevisível e aterrorizante) e exige que a pessoa experimente níveis extremos de três dos quatro sintomas de "desconforto de separação" (pensamentos intrusivos sobre o falecido, ansiando pelo falecido, procurando pelo falecido e solidão excessiva desde a morte), bem como níveis extremos de quatro dos oito sintomas de "sofrimento traumático" (falta de propósito em relação ao futuro; dormência) desapego ou ausência de resposta emocional; dificuldade em acreditar ou reconhecer a morte; sentir que a vida é vazia ou sem sentido; sentir que parte de si mesmo 
morreu; visão de mundo destruída; assumir sintomas de comportamentos prejudiciais da pessoa falecida; irritabilidade excessiva, amargura ou raiva relacionada à morte) (KREUZ; ANTONIASSI, 2020).

Esses sintomas devem ter durado pelo menos seis meses e levar a um comprometimento funcional significativo. Como os pais de crianças que morrem correm maior risco de sintomas de estresse traumático e desregulação emocional, eles correm maior risco de luto complicado (VERZTMAN et al., 2020).

Verificou-se também que irmãos de crianças que morrem correm maior risco de problemas de externalização e internalização quando comparados a normas e controles dentro de 2 anos após a morte. O luto complicado foi menos claramente definido para as crianças, mas acredita-se que também inclua sintomas de TEPT, outras características psicológicas associadas a esse distúrbio e luto (TIZÓN, 2019).

\section{Papel e a perda dos pais de uma criança}

0 processo de conceber, dar à luz e criar filhos é compartilhado por praticamente todos os animais vivos. A experiência humana desse processo, no entanto, acrescenta muitos elementos de construção psicológica, social e de significado. Em vários estágios do ciclo da vida, homens e mulheres se relacionam com os papéis de conceber e criar filhos como essenciais para sua existência. Dos vínculos formados na família, o vínculo pai-filho não é apenas particularmente forte, mas também é parte integrante da identidade de muitos pais e filhos. Muito foi escrito sobre o significado do vínculo pai-filho como um dos principais organizadores do senso positivo de si dos pais e de relacionamentos significativos com os outros (VERZTMAN; ROMAO-DIAS, 2020; COSTA et al., 2020).

Os pais de crianças e adolescentes que morrem sofrem de uma ampla variedade de sintomas físicos e mentais difíceis. Como em muitas perdas, os sentimentos deprimidos são acompanhados por intensos sentimentos de tristeza, desespero, desamparo, solidão, abandono e desejo de morrer. Os pais geralmente apresentam sintomas físicos como insônia ou perda de apetite, além de confusão, incapacidade de concentração e pensamento obsessivo. Sentimentos extremos de vulnerabilidade, ansiedade, pânico e hipervigilância também podem acompanhar a tristeza e o desespero (COSTA et al., 2020).

Os pais enlutados evidenciam raiva como parte da reação normal à perda do filho. Isso pode ser expresso como raiva intensa ou como irritação e frustração crônica. Pode ser dirigido ao cônjuge, a outros membros da família, à equipe profissional, a Deus, ao destino ou até ao filho morto. A raiva também pode ser dirigida a si mesmo, criando sentimentos de ódio próprio, vergonha e inutilidade (TIZÓN, 2019).

As crianças assumem grande importância simbólica em termos de generatividade dos pais e esperam isso no futuro. Todos os pais sonham com o futuro de seus filhos; quando uma criança morre, os sonhos também podem morrer. Essa morte do futuro parece essencial para a intensidade das respostas de muitos pais. Três temas centrais na experiência dos pais quando uma criança morre incluem: (a) a perda do senso de competência e poder pessoais; (b) a perda de uma parte do eu e; (c) a perda de um filho. Embora a culpa e a auto-culpa sejam comuns no luto, elas são especialmente pronunciadas após a morte de uma criança. A competência de papel dos pais como cuidadora, protetora e mentora da criança é severamente ameaçada pela morte prematura (COSTA et al., 2020).

Os pais afirmam que sua dor continua ao longo de suas vidas, muitas vezes dizendo: "Fica diferente, não fica melhor". Palavras como "fechamento" podem ser profundamente ofensivas. Os poucos estudos que acompanham os pais há anos após a morte da criança apoiam o conceito de sua preocupação com a perda de filhos ao longo do ciclo da vida. A carta de Freud a um amigo sobre a perda de sua filha mais velha descreve isso eloquentemente:

Por anos eu estava preparado para a perda de meus filhos (na guerra); e agora vem o da minha filha. Como sou profundamente irreligioso, não há quem possa acusar e sei que não há nenhum lugar para o qual qualquer queixa possa ser tratada. "O círculo invariável dos deveres de um soldado" e o "doce hábito da existência" garantirão que as coisas continuem como antes. No fundo, consigo traçar os sentimentos de uma profunda mágoa narcísica que não deve ser curada (JONES, 1957, p.20 Apud BOWLBY, 2016, p. 79).

Os pais resistem à ideia de que se recuperarão da morte de seus filhos. Em vez de "recuperação" ou "resolução", que sugere um retorno ao funcionamento antes da perda, "reconciliação" e "reconstituição" foram usadas para descrever o período pós-morte, porque esses termos refletem mais adequadamente as mudanças profundas que ocorrem quando uma criança morre. Eles expressam a realidade de que mesmo o processo de luto bem-sucedido resulta em uma transformação na pessoa resultante da morte de um ente querido (TAVARES, 2020). 
Para tornar o luto compreensível, segundo Tizón (2019), é necessário estudá-lo em sua totalidade, onde é influenciada e determinada por fatores psicológicos e sociais, antropológicas e até econômicas que ocorrem como consequência de uma situação ou realidade vivida. Isso não deve ser considerado apenas como uma experiência individual, mas também coletivo, influenciado e determinado pelo cultural e social em cada momento da história. Para Tizón, é importante considerar os fenômenos mentais e comportamentos envolvidos nos processos de luto, após a perda de um ente querido.

Nesse sentido, Neimeyer (2017, p. 1) afirma: "embora a dor, a solidão e os transtornos que acompanham o luto não têm nada de "anormal", existem alguns sintomas que devem fazer que procuremos um profissional ou alguém em nosso ambiente que possa ajudar". Essas concepções mostram que embora o luto seja uma experiência de dor pessoal, é preciso que cada pessoa ao sentir busque suporte em seu ambiente mais próximo ou um profissional.

Os processos de luto e a elaboração do luto incluem tristeza, que é preciso tentar curar, elaborar e resolver a tempo de evitar danos maiores que a readaptação da pessoa ao mundo social. Conforme expresso por Tizón (2019), o luto é uma situação diacrônica, que segue um processo. Os resultados de tal processo não precisam ser negativos para a pessoa enlutada, para a dívida: uma elaboração adequada do luto tem uma série de indicadores e pode levar ao enriquecimento pessoal, crescimento individual e psicossocial, enquanto o luto impróprio levará a problemas para o desenvolvimento pessoal a nível psicológico, biológico e psicossocial.

Embora o luto possa ser vivido sozinho ou na companhia de outras pessoas, deverá cumprir etapas com características próprias, o que auxiliará o devedor a elaboração do processo de luto. Neimeyer (2017) argumenta que a pessoa quando estiver passando pela perda de um ente querido, deve cumprir certas fases do luto -tarefas-, que devem ser realizadas na íntegra, permitindo assim, com base nessas tarefas, que o devedor possa desempenhar um papel ativo na preparação de seu processo.

É muito importante que a pessoa possa realizar as diferentes tarefas, deixando escapar a expressão de dor. Por outro lado, deve estar aberto à aceitação da morte como irreparável, onde a pessoa não retornará mais e deve dar a esta pessoa um novo prêmio. Em relação às tarefas, a primeira delas é a aceitação da realidade do ente perdido. Esta tarefa refere-se à dificuldade em aceitar a morte de uma pessoa que é amada, portanto, persiste um sentimento de que a perda não é real. 0 cumprimento desta tarefa ocorre quando o sujeito pode ver que a perda aconteceu, tornando-se parte de sua nova realidade, percebendo assim a irreversibilidade do perdido. Leva tempo para ser capaz de aceitar a realidade da perda, porque se deve ter uma aceitação tanto intelectual quanto emocional, o que talvez seja o mais difícil. (NEIMEYER, 2017)

A segunda tarefa envolve ser capaz de trabalhar as emoções e a dor da perda. Neste momento, sentimentos raiva, ansiedade, culpa, dor física e emocional, tristeza, entre outros. Quanto à raiva, esta manifesta-se relacionada à irreversibilidade da perda, onde a pessoa sente raiva por não ser capaz de fazer nada para mudar as coisas; essa raiva pode ser contra ele mesmo ou outros. A ansiedade também surge em um luto, é esperado e normal que apareça e pode estar presente novamente ao longo do processo. Como disse Bowlby (2016), essa ansiedade é uma resposta da pessoa quando a figura de afeto é encontrada temporariamente ausente, mas quando essa ausência é permanente, a resposta será dor e tristeza.

Vale ressaltar que nem todos os sujeitos vivenciam a dor da mesma forma e com a mesma intensidade, a sensação de dor é única e intransferível. A terceira tarefa a que Gomes et al. (2015) se referem levanta a necessidade de se adaptar a um meio em que o falecido está ausente, o que implica adaptação a um meio onde o ente querido se foi e deixou um espaço vazio. Com o tempo, as representações negativas darão lugar às positivas e fornecerão a possibilidade de continuar com suas tarefas ou aprender outras, e buscar novas formas de lidar com o mundo. 


\section{PROCEDIMENTOS METODOLÓGICOS}

Esta pesquisa foi realizada por meio de uma pesquisa bibliográfica sistemática de literatura, em artigos científicos indexados nas bases de dados, seguindo as seguintes etapas:

[1] 1a - elaboração da pergunta norteadora (identificação do tema e seleção da hipótese ou questão de pesquisa para a elaboração da revisão sistemática);

[2] 2a - busca ou amostragem na literatura (estabelecimento de critérios para inclusão e exclusão de estudos/ amostragem ou busca na literatura).

[3] 3 a - coleta de dados (definição das informações a serem extraídas dos estudos selecionados/categorização dos estudos);

[4] 4a - análise crítica dos estudos incluídos (avaliação dos estudos incluídos na revisão integrativa);

[5] $5^{\mathbf{a}}$ - discussão e interpretação dos resultados e;

[6] 6 - apresentação da revisão sistemática, ou seja, apresentação da revisão/síntese do conhecimento).

Fonseca (2012, p. 32) salienta que "a pesquisa bibliográfica é feita a partir do levantamento de referências teóricas já analisadas, e publicadas por meios escritos e eletrônicos, como livros, artigos científicos, páginas de web sites".

Os artigos foram coletados nas bases de SciELO, Public Medline or Publisher Medline (PUBMED) e PePsico sobre os principais impactos psicológicos que acometem os pais com o luto de um filho.

Para a realização da busca utilizou-se os descritores "luto", "luto parental", "psicologia", bem como os respectivos descritores em língua inglesa.

Os critérios de inclusão foram artigos publicados entre 2015 e 2020 nos idiomas português e inglês, que descrevessem sobre os principais impactos psicológicos que acometem os pais com o luto de um filho. Todas as demais amostras foram imediatamente excluídas.

Já os critérios de exclusão foram: estudos duplicados, disponíveis só o resumo ou com a apresentação apenas do tema, estando o conteúdo indisponível e artigos pagos.

Depois da leitura dos títulos e resumos, seguiu-se a recuperação dos artigos selecionados, de acordo com os critérios de inclusão e exclusão mencionados anteriormente. Os artigos recuperados na íntegra constituíram o corpus da pesquisa.

Ao término das leituras, foi realizada, primeiramente, fichamentos e resumos acerca do que era mais importante e que comporia os resultados do Trabalho de Conclusão de Curso. Posteriormente, uma análise descritiva de dados extraídos dos estudos selecionados que foram: autor (es), ano, base de dados, objetivo e resultados.

Gerou-se um quadro que apresenta os resultados da pesquisa, utilizando-se um total de 25 artigos, 1 trabalho de conclusão, 1 dissertação de mestrado, 2 teses de doutorado e 9 livros específicos.

Foram respeitados todos os aspectos legais dos direitos autorais, conforme preleciona a Lei 9.610, a fim de dar um caráter de lisura ao processo de revisão bem como, os devidos créditos aos autores dos artigos compilados para subsidiar os resultados da presente pesquisa.

Os principais achados referentes às pesquisas analisadas podem ser evidenciados no Quadro 1 (APÊNDICE A), conforme metodologia aqui apresentada. 


\section{RESULTADOS E DISCUSSÃO}

\section{Sentimentos que envolvem o luto dos pais na perda de um filho}

Em certas circunstâncias onde há perda de pessoas, de representações mentais entre outras, reações afetivas são produzidas no indivíduo cognitivo-comportamentais que são chamados de perdas por Tizón (2019). Luto, ao contrário, é o conjunto de fenômenos que são desencadeados após uma perda. No processo de luto, há mudanças nos níveis psicológico e psicossocial, que permitem elaborar internamente a perda nas pessoas ao longo do tempo. As pessoas afetadas experimentam sentimentos de pesar, tristeza, muitas vezes há queixas de natureza somática e física.

ZwielewskiI e Sant'Ana (2016) mencionam que existem muitas formas de se perceber a morte, mas, ao se falar em luto, inevitavelmente se fala em tristeza, e a forma como as pessoas vivenciam essa tristeza precisa ser compreendida considerando prioritariamente a civilização, a cultura, a religião e a idade da pessoa enlutada. Isso decorre do fato de a morte ter diferentes significados em diferentes contextos culturais. 0 grau de parentesco, o gênero, o tipo de morte, os vínculos e os recursos internos disponíveis a cada indivíduo influenciam na sua forma de vivenciar a tristeza e a situação do luto.

Este processo também envolve luto, que é apontado por Tizón (2019) e Lopes et al. (2017) o conjunto de manifestações externas, sociais e culturais, que sustentam e dão acesso ao reajuste no mundo social após a perda, tudo isso permite ir elaborando esta situação tanto interna quanto externamente, para alcançar a aceitação da nova realidade, com o passar do tempo. Para este autor, atualmente os modos de relacionamento mudaram, o que por sua vez, implica como eles se manifestam publicamente em uma situação de luto.

As demandas da sociedade de hoje no que diz respeito ao tempo e imediatismo necessários, tanto em termos de procedimentos e tarefas como nas relações interpessoais, levam a questionar se é possível experimentar adequadamente um processo tão complexo como um luto, afirmando que "nós temos apenas o" remédio "da dissociação, negação e desistência, negação da experiência afetiva, dos processos de luto e da elaboração" (TIZÓN, 2019, p. 27).

ZwielewskiI e Sant'Ana (2016) salientam que os sintomas relacionados à perda de uma pessoa com quem se teve relacionamento próximo (luto) mais comumente relatados são: os emocionais (tristeza profunda, culpa, ansiedade e solidão), os comportamentais (falta de concentração, choro, sonhos com a pessoa falecida, o apego ainda maior a objetos pertencentes ao falecido), os cognitivos (descrença, preocupações, alucinações e confusão mental) e os físicos (falta de ar, maior sensibilidade aos ruídos, falta de energia e despersonalização).

Um luto pode ou não se tornar patológico, dependendo da intensidade e duração das reações emocionais da pessoa, conforme afirma o autor Cabodevilla (2017). Em muitos casos, existem dificuldades na resolução de um luto, com o qual Neimeyer (2017) afirma que: Luto complicado, anormal ou patológico é a intensificação do luto no nível que a pessoa está sobrecarregada, recorre a comportamentos inadequados ou permanece indefinidamente neste estado sem avançar no processo de luto para a sua resolução. Isso implica processos que não vão para a assimilação ou acomodação, mas, em vez disso, leva a repetições estereotipadas ou interrupções frequentes na cura.

Continuando com o que é expresso por Neimeyer (2017), encontramos diferentes tipos de luto. Luto crônico é aquele que tem duração indefinida, no qual não é possível chegar para concluir e a pessoa que sofre muitas vezes está ciente de que não pode realizar a culminação. Luto retardado é aquele em que a pessoa no momento da perda, manifesta uma reação emocional, que não foi suficiente, e com o passar doo tempo começa a mostrar sintomas de luto que aconteceram no passado. Esta muitas vezes ocorre quando as circunstâncias que envolvem a situação de perda fizeram com que a pessoa atrasasse seu luto.

Luto exagerado é aquele em que a pessoa experimenta um transbordamento completo de comportamentos inadequados; neste luto apresentam-se grandes transtornos psiquiátricos que aparecem após a perda, um exemplo disso pode ser depressão clínica. 0 luto mascarado ocorre quando na pessoa existem certas reações que estão ocultas, onde há sintomas e comportamentos que causam conflito nos relacionamentos, sem ser capaz de se dar conta da origem a que estão associadas ao prejuízo sofrido. Os afetados procuram equivalentes afetivos do luto ou somatizam, causando diferentes doenças psicossomáticas inexplicável na época (NEIMEYER, 2017).

Algumas pessoas não conseguem terminar seus lutos corretamente com o que um luto patológico pode ocorrer, o que muitas vezes gera problemas no emocional, bem como conflitos, somatizações, entre outros. Em relação ao luto patológico, Bowlby (2016) considera que embora compartilhe certas características 
com o luto que se realiza de forma normal, a diferença é que o patológico apresenta um exagero ou deformação das fases do luto. As variáveis patológicas do luto determinam muitas formas de alterações de saúde física, bem como saúde mental. 0 autor considera que em ditos lutos, há duas variedades a considerar, uma delas é a presença de emoções e sentimentos intensos, onde ocorrem explosões de raiva e autocensura.

Segundo o referido autor, a pessoa afetada tem dificuldades para reconstruir sua vida, apresentando depressão como o principal sintoma e frequentemente alternando com ansiedade. Por outra parte a pessoa pode ter uma reação diferente, oposta à acima mencionada, em que há uma falta de sofrimento mais ou menos prolongada de forma consciente, para que sua vida continue como se nada tivesse acontecido, também pode ser afetado por doenças físicas e psicológicas, e inexplicavelmente, abrupta, chega a apresentar uma depressão. É importante notar que nas variáveis expostas, o luto se apresenta de forma inconclusiva, não se resolve.

Para Gonçalves (2014, p. 03), a intensidade e a duração do processo de luto "são muito variáveis, não só no mesmo indivíduo ao longo do tempo ou após diferentes perdas, mas também em pessoas diferentes, após perdas claramente similares".

Bowlby (2016), partindo da contribuição de outros autores, faz uma classificação do luto patológico em crônico, deformado e eufórico. Mas considerar isso para realizar um luto normal ou patológico, existem certas variáveis que influenciam, o que ele classifica de forma geral, como fatores que afetam o curso do luto, tomando o mais significativo para luto patológico. Ele os agrupa em cinco variáveis. Em primeiro lugar, identidade e o papel da pessoa perdida, de modo que a perda de um membro significativo com quem a pessoa manteve um vínculo afetivo, como a morte de uma das figuras parental é considerado um fator de risco para luto patológico. Bem a pessoa diante da perda deve ocupar, assumir novos papéis, tanto na família como também no social, entre outros. Você terá que reorganizar sua vida tanto no nível individual como uma família, uma vez que a pessoa perdida ocupava um papel, e quando um alto grau de dependência econômica ou de bens materiais, é possível que haja uma maior afetação da pessoa que sofre a perda, visto que ela terá que assumir outras responsabilidades.

Outra perda considerada fator de risco é a morte de um filho, pois os pais não estão preparados, seria um acontecimento inesperado. 0 sexo e a idade da pessoa que sofre a perda é outro fator relevante, visto que quanto mais jovem você for no momento da perda, maior o risco de luto patológico. É possível considerar as mulheres mais vulneráveis, em relação às perdas, mas é preciso levar em consideração sua personalidade e como era o vínculo afetivo. Em relação a essa vulnerabilidade, ela pode ser reafirmada com o que foi afirmado por Echeburúa (2019), onde o trauma é vivenciado com mais frequência e mais gravidade nas mulheres, especialmente quando sofrem agressão sexual ou morte violenta de criança.

Na terceira variável, Gonçalves (2014) mostra que estão as circunstâncias e causas da perda, referindo-se ao momento em que ocorre, assim como os eventos que causaram a referida morte. Se a morte se origina de forma abrupta e repentina, como por exemplo em um acidente, os efeitos causados não serão os mesmos de quando você tem conhecimento de, por exemplo, uma doença, que permite uma preparação prévia. A morte súbita pode causar dificuldades no plano emocional, como ser, uma depressão com sentimentos de raiva, autocensura, ansiedade, entre outros; as circunstâncias que cercam a morte podem apresentar uma dificuldade para a resolução do luto.

Continuando com esse argumento, segundo a autora estão as circunstâncias sociais e fatores psicológicos da pessoa que sofreu a perda. Aqui é importante levar em consideração o ambiente da pessoa, a cultura da qual faz parte, desde as formas de considerar a morte e as maneiras de passar pelo luto variam de uma cultura para outra. Recursos com aqueles que a pessoa conta também são muito importantes, como nível educacional, econômica, social, entre outras, e o apoio que tanto os familiares quanto amigos dão nesse momento.

A quinta e última variável, segundo Echeburúa (2019), é a personalidade de quem sofreu a perda. É a variável mais importante para determinar o curso do luto; há pessoas que são mais vulneráveis do que outros em termos de personalidade. Vai depender das ferramentas disponíveis em um nível psicológico e emocional para lidar com as perdas, como ele organiza seus comportamentos em relação aos vínculos afetivos e como responde a situações que geram estresse.

No que diz respeito ao luto patológico, existem várias classificações que fazem diferentes autores; neste trabalho, apenas alguns foram levados em consideração em geral nas classificações, como um exemplo para diferenciá-lo do processo de luto que é realizado sem complicações que determinam o curso dela 
desfavoravelmente. 0 seguinte será levado em consideração em relação ao luto dos pais pela perda de um filho, como afirmam os diferentes autores.

Considerando a família como um sistema muito importante dentro de uma sociedade, a perda de um filho é muito difícil, causa muita dor aos pais, também aos outros membros da mesma como é o caso dos irmãos. Mais complexa pode se "tornar a situação em que o filho ainda fazia parte da estrutura familiar, não era independente, não havia atingido todas as suas possibilidades no processo de separaçãoindividuação" (TIZÓN, 2019, p.320).

Essa situação leva a família a passar por uma crise, com desentendimentos que eles perturbam o equilíbrio e podem causar uma falha no sistema. Assim como a perda de um membro significativo permite uma reaproximação entre os membros e eles fortalecem os laços entre si, ao longo do tempo. Para atingir o equilíbrio dessa família, é importante considerar segundo Neimeyer (2017) o impacto causado pela morte em todo o sistema, levando em consideração que embora as reações são diferentes em cada membro, a situação foi vivida por toda a família, para qual a elaboração do luto dependerá de como a família realiza o processo tornando mais fácil ou mais difícil.

\section{Consequências psicossociais de pais enlutados}

Esta seção aborda como o luto pode interferir na vida social e nos aspectos psicológicos dos pais que perderam seus filhos.

Lemos e Cunha (2015) apresentam e discutem um conjunto de reações subsequentes a uma perda, dividindo-os em quatro categorias: 1) manifestações emocionais - como sentimento de tristeza, solidão, culpa, raiva, irritabilidade, vazio, ansiedade, choque, desespero, desamparo, desilusão, desesperança, inadequação e fracasso; 2) manifestações cognitivas - ligados a pensamentos de baixa autoestima e confusão; além de dificuldades de concentração, falta de memória e dificuldade no raciocínio, que traduzem a preocupação com o bebê e constituem os sintomas mais referidos; 3) manifestações comportamentais - que refletem em agitação, fadiga, choro, isolamento e a tendência para procurar ou, opostamente, evitar estímulos associados ao bebê; e 4) manifestações fisiológicas - como aperto no peito, nó na garganta, dificuldade em respirar, palpitações, tensão muscular, náuseas, dormência, falta de energia, insônia e pesadelos. As autoras pontuam que estes diferentes sintomas são mais intensos nos primeiros meses após a perda e desenvolvem-se de maneira subjetiva, no que diz respeito à sua diversidade e intensidade.

No que diz respeito aos pais, é da maior importância reconhecer e compreender que cada um precisa elaborar seu processo antes da perda, apoiando um ao outro, e com a ajuda do meio ambiente se necessário, porque ambos os pais sofreram uma perda, "mas a experiência de luto pode ser diferente para cada um porque eles tinham um relacionamento diferente com seu filho e seus estilos diferentes de vida" (NEIMEYER, 2017, p. 32). Os pais muitas vezes se surpreendem com suas próprias respostas e necessidades, visto que este é um tipo de perda onde fases, tarefas ao resolver o processo de luto, são extremamente dolorosos e difíceis.

Echeburúa (2019), por sua vez, afirma que a perda de um filho pequeno é um estressante na vida de uma pessoa e ainda mais se a morte ocorrer em um imprevisto, como um acidente. Lopes et al. (2017) destacam que o processo de luto é lento, doloroso e afasta o enlutado das atividades que não estejam ligadas ao objeto perdido, de maneira que a devoção ao luto leva à perda de interesse pelo mundo externo

A perda de um filho segundo Echeburúa (2019) pode provocar nos pais reações psicológicas, profunda tristeza, pesar, dor e sintomas somáticos também podem aparecer como insônia, perda de apetite, entre outros. Essas reações que são presentes no luto variam em intensidade com o passar do tempo, e não marcam necessariamente a evolução dele. Existem pessoas que inicialmente têm uma reação emocional moderada, e depois eles experimentam outras emoções com maior profundidade. Pais diante da situação, usam formas de encarar a realidade, que podem variar dependendo da personalidade de cada um. A morte de um filho pode testar a estabilidade do casal e apresenta-se como um grande desafio, onde tal situação produz muito estresse e esta pode desencadear críticas de ambos os lados.

Segundo Echeburúa (2019), um fator de risco que pode desencadear um luto patológico, é a instabilidade emocional anterior dos pais. Se eles apresentarem história de depressão, transtornos de ansiedade, transtornos de personalidade, entre outros, com formas de lidar com as perdas inadequadas; correm mais risco de colapso e apresentar luto patológico em caso de morte trágica de uma criança. 
"Algumas famílias lidam com sentimentos sobre a morte de uma criança suprimindo os fatos em torno da perda" (NEIMEYER, 2017, p.31). As famílias têm diferentes maneiras de tolerar e expressar sentimentos, aquelas que lidam com isso em uma maneira mais eficaz são aquelas que podem falar abertamente sobre $o$ falecido, mas em vez disso existem outros que não podem falar livremente, dando desculpas ou desviando $\mathrm{o}$ assunto para que outras pessoas fiquem quietas.

De acordo com Bowlby (2016), existem certas fases do luto pelas quais os pais passam após a morte de um filho. Estes seriam: embotamento da sensibilidade, fase de descrença com o desejo de reverter o resultado, e fase de desorganização e reorganização da vida, conforme ela continua. Descrença quando dada assim parcial, pode ser usada para controlar afetos dolorosos, mas depende de seu grau e persistência, pois muitas vezes isso também leva a atividades em excesso, o que não é vantajoso, visto que é necessário realizar um processo para uma aceitação da nova situação, há pais que permanecem com certo grau de descrença após meses de perda.

Aqueles que conseguem realizar um processo lamentando de forma favorável, eles podem reconhecer, aceitar a nova situação e que seu filho possa retornar. Desse modo, Tizón (2019) acrescenta que embora a crise profunda e as dificuldades que esta realidade acarreta, é vivida a nível pessoal e familiar de diferentes maneiras, onde as pessoas podem, apesar da dor, continuar a viver suas vidas com uma nova inserção no meio social.

Sentimentos de desesperança, perda de vida tem sido estudados em mães e sua autoestima e a confiança de ser boa mãe, sentir-se rejeitada pelos outros, desenvolvimento dissociado do marido, sentimento de ser acusado por ele (TIZÓN, 2019).

No que se refere à reinserção no meio social, vale ressaltar o que foi levantado por Neimeyer (2017), que reforça que quando um membro importante da família morre perturbando o equilíbrio de unidade, outras alianças devem ser formadas. As manobras para formar essas novas alianças podem produzir angústia e tensão consideráveis na família. É muito importante destacar isso, levando em consideração que cada membro processará as tarefas em seu próprio ritmo e de sua maneira, tendo em vista que a vontade e a disposição serão diferentes em cada pai.

Um ponto significativo a se levar em consideração é o ponto levantado por Worder (2008 Apud NEIMEYER, 2017), segundo o qual muitas pessoas procuram ajuda física e mental, sem saber que por trás dessa sintomatologia estão presentes as consequências de um luto.

Muitas doenças psiquiátricas são a expressão de luto patológico. Essas doenças incluem, em muitos casos, estados de ansiedade, depressão, histeria e até mais de um tipo de transtorno de personalidade. A maioria dos estudos mostram que pessoas enlutadas apresentam mais sintomas deprimido durante o primeiro ano do que os indivíduos que não estão no processo de luto. Para que a elaboração do luto possa ser realizada de forma favorável, é de extrema importância o que afirma Echeburúa (2019), onde os pais devem usar estratégias de enfrentamento saudáveis, que junto com o passar do tempo serão de muita ajuda para a enfrentar a situação vivida.

É essencial que os pais sejam capazes de alcançar uma aceitação da referida perda, sua irreversibilidade, dar expressão às emoções negativas relacionadas ao que aconteceu, mas também é necessário realocar as memórias da pessoa perdida de uma forma positiva. Ser capaz de compartilhar se você pode sentir dor com os outros, sem querer esconder a tristeza, isso pode ser realizado de diferentes formas e dependendo do momento. Então, com o passar do tempo, há necessidade de pensar na pessoa falecida sem dor, culpa ou ressentimento, sem sentimento oprimido pela memória. Outro ponto significativo é que os pais devem buscar metas e projetos para suas vidas, dando-se a possibilidade de estabelecer outras novas relações que enriquecem (Echeburúa, 2019).

O luto pela morte de uma criança é um luto especial com características específicas que marca um antes e um depois na vida de seus pais, constituindo um evento inevitável. A esse respeito, Costa et al. (2020) e Crepaldi et al. (2020) apontam algumas características desse luto especial como: sentimento de culpa, maior duração do processo, dor pontual, como aquela dor intensa que aparece na frente da memória da criança que se foi, e o caráter insubstituível que o objeto assume.

Worden (2015) em sua pesquisa sobre o tratamento do luto, afirma que a culpa conquista um grande espaço na perda devido à responsabilidade que é dada a uma mãe após o nascimento de seu filho, a responsabilidade de vida, e ver o filho morto pode gerar sentimento de impotência, incapacidade e culpa.

Da seguinte maneira, Costa et al. (2020) apontam que a morte de uma criança tem diferenças no que diz respeito à dor em relação com outros lutos. García (2020) em sua tese de doutorado investigou o 
significado de perder um filho na ótica de mães e pais que sofreram esse evento. Em relação ao autor conclui que a dor, a ausência e o vazio que a morte de um filho produz é vivida tanto física quanto psicologicamente e socialmente. O luto se manifesta como um distúrbio muito óbvio carregado com perguntas e um discurso, às vezes, incoerente e desorganizado em que há ideias recorrentes sobre o evento e uma decadência física.

Por meio de sua pesquisa, García (2020) também conclui que existem diferenças entre os significados que ocorrem na elaboração do luto pelos pais e mães; nesse sentido, as mães frequentemente falam, refletem e choram mais do que os pais, que ficam calados e com o objetivo de eliminar a nostalgia. A este respeito, além de ambos os pais sofrerem a mesma perda, a experiência de luto pode ser diferente para cada um porque eles tinham um relacionamento diferente com seu filho e seus estilos diferentes de lidar.

Freitas e Michel (2015) estudaram e refletiram sobre a experiência do luto maternidade na sociedade brasileira, concluindo que a perda de um filho nunca é passada. Quando a morte de uma criança ocorre de forma inesperada e abrupta, muitas vezes, o sentimento materno de perda piora levando à não aceitação de tal evento.

Segundo Ergo e Faas (2015) a primeira reação materna diante da morte de um filho é a não aceitação. 0 pensamento inicial referente a não aceitação deriva da reflexão sobre a interrupção da ordem natural da vida: nascer, crescer, reproduzir, envelhecer e morrer. A mãe espera não estar presente para ver seu filho cumprir seu ciclo natural, no entanto, em alguns casos o ciclo natural é rompido, causando dores indescritíveis na vida da mãe enlutada pela morte de seu filho.

García (2020) expressa que perder um filho não se torna um problema, mas sim a necessidade de ter que sobreviver a ele. Frizzo et al. (2017) investigaram os processos de elaboração de lutos em mães que perderam filhos abruptamente. Nesta investigação os autores encontraram elementos comuns nos diferentes processos de luto, a saber: sentimento de culpa ao sentir que seu papel principal como protetores não era percebido, a criança é idealizada por meio do discurso onde encontra conforto, e a necessidade urgente de compartilhar sua experiência dolorosa com os colegas desde a perda do filho fere seu próprio narcisismo.

Em relação ao acima exposto, Gomes et al. (2015) investigaram a experiência de luto em uma mãe cuja filha se suicidou, afirmando que a vida da mãe muda completamente, que se culpa pela ineficiência de seu papel de criar, cuidar e proteger sua filha, perdendo suas fantasias de ser mãe e sua projeção sobre a vida de sua filha. A mãe expressa sua frustração e culpa por não ter cumprido seu papel adequadamente. A primeira característica particular que define o luto de uma mãe que perde seu filho abruptamente é um atraso no desenvolvimento deste processo. 0 prolongamento do trabalho de luto também é uma de suas características, que, juntamente com o atraso no seu preparo, podem ser decorrentes de inimaginável, impensável e antinatural desse tipo de perda.

Outra das características Tizón (2019) conclui em sua pesquisa é a dor. A este respeito o referido autor aponta que as mães descrevem a dor causada pela morte de um filho não como qualquer dor, mas uma dor que dilacera e oprime o peito, uma dor intensa caracterizada como aquela que sempre estará presente na vida dessas mulheres, que devem aprender a viver com ele. Sobre o acima, García (2020) aponta que a dor é ainda mais intensa e duradoura no caso de morte de crianças e adolescentes.

Em relação ao exposto, quando a morte é de uma criança, a morte é vista como algo injusto ou absurdo, e os pais tentam entender o que aconteceu e sentem-se culpados, a culpa que aumenta é acompanhada de reprovação quando a causa da morte for violenta ou acidental.

O acima também é evidenciado por Sales (2015), que investigou o luto antecipado e inesperado, concluindo que existem diferenças entre os dois. Para o autor, o efeito de antecipação que imprime diferenças no enfrentamento do luto em dependendo do tipo de morte, antecipada ou inesperada, súbita e / ou trágica. Nesse sentido, o autor destaca que a antecipação da perda possibilita uma maior aceitação da morte, em vez de perdas repentinas e inesperadas que requerem mais tempo para serem aceitos.

Medeiros (2016) estudou a elaboração do luto em pais que perderam um filho em um acidente de trânsito, e eles apontam que, embora a intensidade do luto por crianças falecidas diminui com o tempo, eles têm a peculiaridade de se tornar muito dolorido rapidamente ao relembrá-los. É sobre uma dor específica que se alterna com lembranças agradáveis e aquelas com essas características se prolongam no tempo.

Rolim et al. (2018) embora tenham focado suas pesquisas nos efeitos em luto por mães de filhos desaparecidos, eles concluíram que antes do desaparecimento de seus filhos (impunidade e falta de seus 
corpos) mães não foi capaz de enterrá-lo. Esta situação é transferida para um impedimento na elaboração simbólica da perda, constituindo um processo de luto "alterado"; chamado Luto na impunidade".

$\mathrm{O}$ acima aponta que o ato simbólico de sepultamento constitui um componente essencial dos ritos funerários em nossa cultura, que eles permitem a elaboração do luto em mães que perderam um filho.

O simbolismo dos rituais expresso em cerimônias públicas ou privadas permite que se aceitará a realidade da morte. Os afetados abrem o processo de despedida de seu amado. Por meio dessas cerimônias, os laços afetivos são fortalecidos, aqueles próximos a dois dão suporte moral, a expressão de emoções intensas é facilitada onde a tristeza é compartilhada e o conforto é encontrado. A perda força a revisar o mundo em busca de significados. Quebra-se todas as ilusões e expectativas criadas. Questiona-se as crenças religiosas onde caracteriza Deus como uma figura paternal e protetora. Conscientiza da falta de controle sobre os destinos, que a morte está aí ao lado e que vivemos no futuro que não tem garantia nenhuma (ROLIM et al., 2018).

As formas de lidar com os sentimentos em relação à morte do filho são muito diversas. Alguns pais mantêm o quarto do filho intacto por anos, outros o silêncio dos fatos que cercam a perda, de modo que as crianças mais tarde não sabem nada sobre seus predecessores, embora o "fantasma" do irmão falecido esteja lá o tempo todo, e o filho vivo é o encarregado de seguir uma carreira que atenda a todas as expectativas que os pais têm.

Todas as investigações citadas aqui indicam a dor e angústia gerada pela morte de uma criança, que parece romper com o esquema do ciclo de vida, marcando um antes e um mais tarde na vida de seus pais.

\section{A participação do psicólogo no processo de luto enfrentado pelos pais após a perda de um filho}

A morte é, sem dúvida, um evento estressor na vida de uma pessoa, gerador de muito sofrimento e de alterações psicológicas, fisiológicas, comportamentais e até sociais onde o enlutado está inserido. As dificuldades advindas do luto podem incapacitar e desorganizar a vida das pessoas enlutadas a ponto de não conseguirem lidar com tamanha tristeza (BASSO; WAINER, 2016). Saber diferenciar a tristeza característica de um luto normal daquela considerada patológica é importante para o profissional da área da psicologia, tanto para que o processo de intervenção seja adequado e não cause mais sofrimento quanto para que não se acabe por negligenciar os sintomas do paciente (ZISOOK; SHEAR, 2019).

Compreender as crenças do paciente que foram ativadas com a morte de seu ente querido, qual o seu entendimento sobre a morte e como ele tem enfrentado a situação da perda são elementos importantes para que o profissional da área da psicologia possa identificar os erros de pensamento e os esquemas que estão vinculados ao sofrimento do paciente na situação do luto e ajudá-lo por meio da intervenção (DATTILIO; FREEMAN, 2015).

Segundo Worden (2018), o profissional que trabalha com enlutados é atingido pela experiência de luto de seus pacientes de maneiras diferentes: o cuidado ao paciente pode trazer à consciência, por vezes de forma dolorosa, as próprias perdas do profissional que se vê impactado podendo interferir no tratamento, como também promovendo e ampliando a consciência da morte pelo cuidador.

Um possível fator de proteção que o profissional psicólogo pode contar consiste no conhecido "tripé analítico", preconizado por Freud (1919/1996). Composto por estudo da teoria, trabalho de análise e supervisão, o tripé foi idealizado no contexto da formação do analista na universidade. Tais atividades configurariam possíveis espaços de acolhimento e escuta para as questões emocionais do psicólogo, sendo as experiências emergentes dos atendimentos elaboradas e mais bem compreendidas nestes diferentes momentos de cuidado (ANDERY et al., 2020).

Segundo Carvalho e Meyer (2017), um dos papéis da psicologia diante de intercorrências como o luto é desafiar a mentalidade da morte como tema interdito, buscando identificar as vulnerabilidades e o alto risco dos pais que perderam seus filhos. Cabe à psicologia ajudar os pais e familiares a se apropriar da situação que estão vivendo, de modo que, posteriormente, eles consigam falar do fato ocorrido, assimilá-lo e, algum tempo depois, aceitá-lo. De acordo com Gesteira et al. (2016), os rituais fúnebres ajudam no processo de luto, pois a recuperação é centrada na aceitação, e o velório permite que as pessoas se despeçam e que o enlutado seja considerado como tal.

Carvalho e Meyer (2017) afirmam que conhecer os aspectos a serem enfrentados nessas situações traz a possibilidade de prestar um melhor auxílio e acompanhamento, o que se constitui em ação preventiva quanto ao desenvolvimento de dificuldades emocionais posteriores. 
Segundo Casellato (2015) em seu livro "Dor silenciosa ou dor silenciada", a mãe deve enfrentar essa situação da forma como ela e o terapeuta encontrarem, não existindo um único método de transcorrer a análise, um modo certo ou errado, já que cada indivíduo reage de forma diferente. Para Carvalho e Meyer (2017), o terapeuta deve compreender que a mãe se sente impotente quanto a essa situação e que seus sonhos e projetos foram substituídos pela dor da perda. Cabe ao profissional também trabalhar sua readaptação, identificando e resolvendo os conflitos que surgiram após a morte desse filho, valorizando os bons momentos que teve com ele, além de enfatizar a importância de retomar suas atividades e responsabilidades no lar, encorajando-a a redescobrir o prazer da vida.

Para Ramos (2016), a psicanálise atua na contramão em relação ao que é esperado pela sociedade "normatizante" e paralisante que mortifica a expressão da dor, porque suscita nela a sua própria. A escuta psicanalítica abre espaço para que a pessoa enlutada possa expressar, ao seu modo, a sua perda para que, dessa forma, ela reorganize a energia que antes era investida no objeto de amor perdido, sem que exista um tempo pré-estabelecido para isso. Porém, ela não desconsidera que existem processos de luto que demandam mais atenção por se expressarem de forma mais intensa, como é o caso do "luto patológico".

A psicanálise compreende a importância de todos os aspectos elaborados pelos autores que se debruçam no tema do luto, mas sempre entendendo que, por ser um sujeito de singularidade, a pessoa enlutada pode passar pelas diversas fases, sem que se limite por uma sequência lógica de um autor em específico e, ainda assim, caminhar na direção de um desfecho saudável (CAVALCANTI; SAMCZUK; BONFIM, 2018).

\section{CONSIDERAÇÕES FINAIS}

A morte e o nascimento fazem parte do ciclo natural dos seres vivos e são as duas únicas certezas na vida. Porém, a morte de um filho é o pior pesadelo dos pais, com o qual aprendem a conviver. Verificou-se, por meio do estudo, que a dor dessa perda não vai embora, embora possa ser transformada e integrada com o tempo. Sem esquecer que não existem receitas, orientações ou horários, porque cada caso é único e tem seu próprio processo e ritmo.

As pessoas que perdem um ente querido, no caso um filho, vivenciam um processo de luto ou adaptação que ajuda a restaurar o equilíbrio pessoal e familiar quebrado pela morte e se caracteriza por três fases: tristeza, perda e integração. Caso o filho adoeça e a morte seja esperada, o luto dos pais começa a partir do momento em que essa circunstância é conhecida. Quando o filho morre repentina e inesperadamente, ocorre um choque que adiciona caos e depressão aos membros da família. Em ambos os casos, o acompanhamento psicológico por uma pessoa com formação e experiência nas emoções, conflitos familiares e processos de luto que se geram em torno da morte de um filho é útil nesses casos.

Os estudos revelaram que os pais podem experimentar diferentes sentimentos e experiências quando seu filho falece. Alguns deles podem ser conflitos familiares decorrentes de diferentes pontos de vista sobre como lidar com o luto (há quem queira falar sobre isso e quem prefira não falar). As sensações físicas temporárias associadas à fase de luto também podem se manifestar, a partir de: distúrbios do sono, fadiga, falta de energia, hipersensibilidade a ruídos ou sensação de aperto na garganta e no peito. Da mesma forma, as emoções que podem surgir temporariamente quando um filho morre são variadas e pessoais. Alguns deles podem ser: tristeza, culpa, raiva, raiva, bloqueio, ansiedade ou insensibilidade.

Constatou-se, por meio da revisão de literatura sistemática, que o tratamento psicológico do luto é fundamental nesse tipo de perda. As pessoas terão muitas perguntas que nunca poderão ser resolvidas, muitas emoções e pensamentos que as perseguirão e as impedirão de recomeçar.

Os pais que perderam seus filhos de maneira precoce precisarão de um psicólogo para acompanhá-los nesse processo, para ajudá-los a elaborar seu luto de forma personalizada e a passar por cada uma das diferentes etapas, não para que se esqueçam do filho, mas para que possam continuar vivendo sem sua presença e sem a dor intensa do trauma que estão vivenciando.

A terapia vai dar-lhes o espaço de que precisam, junto com sua rede de apoio, para que em algum momento possam voltar a funcionar no dia a dia, mesmo que haja coisas para as quais não sejam mais as mesmas.

Este trabalho não encerra aqui, servindo como ponto de partida e continuação para que novas pesquisas sejam implementadas na intenção de alcançar novos conhecimentos acerca da temática abordada. 
[1] ANDERY, M. C. et al. A vivência do luto de psicólogos dentro das instituições. Rev. SBPH, São Paulo, v. 23, n. 1, p. 25-34, jun. 2020.

[2] ARIÉS, P. Contexto atual das relações familiares. São Paulo: Novo conceito, 2015.

[3] BACCI, P. La muerte y el duelo en la hipermodernidad. Querencia revista de Psicoanálisis, v. 13. Instituto de psicología clínica. 2017. Disponível em: http://www.querencia.psico.edu.uy/revista_nro13/pilar_bacci.htm. Acesso em: 28 jul. 2020.

[4] BASSO, L. A.; WAINER, R. Luto e perdas repentinas: Contribuições da terapia cognitivo-comportamental. Revista Brasileira de Terapias Cognitivas, v. 7, n. 1, p. 35-43, 2016.

[5] BOWLBY, J. A partida: tristeza e depressão. São Paulo: Saraiva, 2016.

[6] CABODEVILLA, I. Las pérdidas y sus duelos. Anales Sis San Navarra, v. 30, supl. 3, p. 163-176, 2017.

[7] CARVALHO, F. T.; MEYER, L. Perda gestacional tardia: aspectos a serem enfrentados por mulheres e conduta profissional frente a essas situações. Boletim de Psicologia, v. 57, n. 126, p. 33-48, 2017.

[8] CASEllato, G. Dor silenciosa ou dor silenciada? 3 ed. São Paulo: Pollo Books, 2015.

[9] CAVALCANTI, A. K. S.; SAMCZUK, M. L.; BONFIM, T. E. O conceito psicanalítico do luto: uma perspectiva a partir de Freud e Klein. Psicol inf., São Paulo, v. 17, n. 17, p. 87-105, dez. 2018.

[10] COELHO FILHO, J. F.; LIMA, D. M. Luto parental e construção identitária: compreendendo o processo após a perda do filho. PsicolArgum. v. 35, n. 88, p. 16-32, 2017.

[11] COSTA, Ana Vera et al. Growing in the shadows of suicide. Nascer e Crescer, Porto, v. 29, n. 2, p. 101-107, jun. 2020.

[12] CREPALDI, M. A et al. Terminalidade, morte e luto na pandemia de COVID-19: demandas psicológicas emergentes e implicações práticas. Estud. psicol. (Campinas), Campinas, v. 37, n.7, p. 1-9, 2020.

[13] DATTILIO, F. M.; FREEMAN, A. (Eds.). Estratégias cognitivo comportamentais de intervenção em situações de crise. Porto Alegre: Artmed, 2015.

[14] ECHEBURÚA, E. Superar um Trauma: o tratamento das vítimas de acidentes violentos. São Paulo: Saraiva, 2019.

[15] ERGO, B., FAAS, A. Logoterapia e Duelo: Uma Aproximación Teórica a La Assistência Terapêutica de Padres que Han Perdido Hijos. Universidad Empresarial Século 21, 2015.

[16] FONSECA, J. J. S. Metodologia da pesquisa científica. Fortaleza: UEC, 2012.

[17] FRANQUEIRA, A. M. et al. O luto pelo filho adulto sob a ótica das mães. Estud. psicol. (Campinas), Campinas, v. 32, n. 3, p. 487-497, Sept. 2015.

[18] FREITAS, L.; MICHEL, L. A maior dor do mundo: o luto materno em uma perspectiva fenomenológica. Psicologia em Estudo, v. 19, p. 273-283, 2015.

[19] FRIZZO, H. C. et al. Mães enlutadas: criação de blogs temáticos sobre a perda de um filho. Acta paul. enferm., São Paulo, v. 30, n. 2, p. 116-121, abr. 2017.

[20] GARCÍA, A. El significado de perder un hijo: la construcción discursiva del duelo de padres y madres. Tesis de doctorado, Universidad de la Laguna, España, 2020.

[21] GESTEIRA, S. et al. O luto no processo de aborto provocado. Acta paul. enferm., São Paulo, v. 19, n. 4, p. 462467, Dec. 2016.

[22] GOMES, Simone Santana et al. O processo de luto pela perda de um filho em uma idosa cuidadora de um paciente crônico. Psicol. hosp. (São Paulo), São Paulo, v. 13, n. 1, p. 64-90, jan. 2015.

[23] GONÇALVES, J. T. Luto parental em situações de morte inesperada: reações à perda, estratégias de coping e perceção de qualidade de vida. Dissertação (Mestrado em Psicologia). Universidade de Lisboa, Portugal 2014.

[24] KREUZ, G.; ANTONIASSI, R. Grupo de apoio para sobreviventes do suicídio. Psicol. Estud., Maringá, v. 25, n. 2, p. 71-82, 2020.

[25] LANÇA, A. M. et al. Recriando a vida: o luto das mães e a experiência materna. Psicologia: Teoria e Prática, v. 19, n. 1, p. 33-39, 2017.

[26] LEMOS, L. F.; CUNHA, A. C. Concepções Sobre Morte e Luto: Experiência Feminina Sobre a Perda Gestacional. Psicol. cienc. prof., Brasília, v. 35, n. 4, p. 1120-1138, Dec. 2015.

[27] MEDEIROS, M. D. Violência no trânsito e juventude interrompida: os impactos da 
[28] morte extemporânea no seio familiar, 2016. Trabalho de Conclusão de Curso (Curso de Psicologia). Centro Universitário Católico de Vitória, 2016.

[29] NEIMEYER, R. Aprendendo com a perda: um guia para lidar com o luto. 2017 Disponível em:

[30] http://www.ignaciodarnaude.com/masalla_experienciaspostmortem/Neimeyer,Aprender\%20de\%20la\%20 Perdida,el\%20duelo.pdf. Acesso em: 29 jul. 2020.

[31] RAMOS, S. A. As diversas faces da perda: o luto para a psicanálise. 2016. Disponível em: <http://pepsic.bvsalud.org/pdf/analytica/v5n9/07.pdf> Acesso em: 15 out. 2020.

[32] ROLIM, Gisleila da Silva et al. Análise do Luto de Mães de Crianças e Adolescentes Desaparecidos. Psicol. cienc. prof., Brasília, v. 38, n. 3, p. 507-521, Sept. 2018.

[33] SALES, P. Trauma, Culpa e Duelo: o trabalho da Psicoterapia Integradora. (2015). Disponível em: http://www.pauperez.cat/index2.php?option=com_docman\&task=doc_view\&gid=50\&Itemid=8. Acesso em: 20 jul. 2020.

[34] TAVARES, T. A. Parentalidade e filiação: os lutos necessários. Revista Lacuna, v. 1, n. 2, 2020.

[35] TIZÓN, J. Perda e Luto: Experiências, Investigação e Assistência. São Paulo: Artmed, 2019.

[36] VERZTMAN, J.; ROMAO-DIAS, D. Catástrofe, luto e esperança: o trabalho psicanalítico na pandemia de COVID19. Rev. latinoam. psicopatol. fundam., São Paulo, v. 23, n. 2, p. 269-290, June 2020.

[37] WORDEN, J. El tratamiento del duel. Asesoramiento psicológico y terapia. 142o. Barcelona: Paidós Ibérica, 2015.

[38] _ _ Terapia do Luto: manual para o profissional de saúde mental. Porto Alegre, RS: Artes Médicas, 2018.

[39] ZISOOK, S.; SHEAR, K. Grief and bereavement: What psychiatrists need to know. World Psychiatry, v. 8, n. 2, p. 67-74, 2019.

[40] ZWIELEWSKI, G.; SANT'ANA, V. Detalhes de protocolo de luto e a terapia cognitivo-comportamental. Rev. bras.ter. cogn., Rio de Janeiro, v. 12, n. 1, p. 27-34, jun. 2016. 


\section{Capítulo 2}

\section{A condição de gênero como fator para o sofrimento psíquico em mulheres e a psicologia feminista}

\section{Ana Thayná de Matos Simplicio}

Resumo: Esta pesquisa buscou compreender a condição de ser mulher em nossa sociedade e como a construção social de o que é "ser mulher" pode ter efeito sobre a saúde mental e fazer com que esta sofra psicologicamente e apresentar a psicologia feminista que é uma prática da psicologia que compreende os papéis de gênero e não os ignora, e sim utiliza destes para realizar sua análise. Com o objetivo de compreender a condição de gênero e identificar o papel da psicologia nas relações de gênero. Utilizando da metodologia de pesquisa bibliográfica sistemática foi analisado através de leitura produções sobre o tema. Através da análise e discussão levantou-se que a condição de gênero em que está inserida a mulher em nossa sociedade tem efeitos sobre sua saúde mental, tendo como consequência o sofrimento psíquico gerado pelas desigualdades enfrentadas pelas mulheres, e que a psicologia como ciência tem um papel importante para a desconstrução dessas desigualdades que geram sofrimento. A partir da introdução das relações de gênero na psicologia, houve uma fusão de psicologia e feminismo abrindo caminho para a psicologia feminista que não se compreende neutra diante das desigualdades de gênero e realiza a análise do sujeito sociocultural e como esta afeta. Ser mulher em uma sociedade construía com alicerces patriarcais como a brasileira é um fator de risco para sofrimento psíquico. Identificando o papel da psicologia nas relações de gênero.

Palavras chave: Gênero; sofrimento psíquico; psicologia feminista; mulher. 


\section{INTRODUÇÃO}

O conceito de gênero é definido pelo movimento feminista como um padrão binário em que constrói e define a forma de ser, perceber, comportar e interagir com os outros. Essa definição é limitada ao sexo e diferenças biológicas entre homens e mulheres e a partir disso é definindo o que é ser homem e mulher, qual seu papel social e valor (ZANELLO; SILVA, 2012).

0 padrão que define gênero é uma relação de poder que define quem é superior e quem é inferior, e essa hierarquia pesa sobre as mulheres que são consideradas o inferior nessa relação. A construção histórica da sociedade ocidental, possui alicerces patriarcais muito fortes, o que faz com que as mulheres tenham vivências e valores distintos dos homens, possuindo papéis sociais diferentes e ocupando um lugar de invisibilidade. Beauvoir (2016) afirma que a mulher é o diferente, a mulher é um "homem incompleto" que está preso a estrutura do corpo que é sua forma de relacionar com o mundo sendo compreendido apenas pelas especificidades corporais. A autora ainda afirma que o feminino do ser humano não é por necessidade uma mulher, as especificidades corporais e suas relações e comportamentos são pautados através dessas, e essa opressão de ser o que o corpo carrega gera sofrimento.

Esse sofrimento afeta principalmente as mulheres, por estarem em um local de inferioridade nas relações de gênero. Gerando estigmas, preconceitos e violências contra as mulheres apenas por ser mulher, e esses estigmas podem aumentar quando além de mulheres essas passam a ser negras ou indígenas entrando estigmas de raças; ou pertencentes a sigla LGBTQIA+ (Lésbicas, gays, bissexuais, transgêneros, queer, intersexuais e assexuais) os estigmas da sexualidade; quando são pobres ou moram em comunidades, são trabalhadoras entrando nos estigmas de classe. (TIBURI, 2018)

A fim de compreender essas definições sociais e seus efeitos na subjetividade humana não se pode fixar a ciência em um padrão "neutro" que não existe, a realidade não é neutra nem imparcial, os marcadores sociais de diferença afetam a existência por completo de um indivíduo, sendo significativo para o desenvolvimento de sofrimento psíquico.

0 contexto em que vivem as mulheres é um potencial para adoecimentos psicológicos, com uma história e realidade de desigualdades e violências as mulheres acabam sendo mais afetadas por doenças como a depressão (CRUZ, 2009).

A condição de gênero a que as mulheres são impostas é de grande vulnerabilidade e o feminismo entrou na ciência fazendo com que esta assumisse o papel de desconstrução da opressão social sobre as mulheres. E para a psicologia o encontro com o feminismo faz uma desconstrução do comportamento masculino e feminino naturalizados e construídos socialmente, compreendendo os papéis sociais de gênero e que estes são ensinados e não natos, que é ensinado desde a infância a performar gênero sendo homens e mulheres (PRENH; MÜNING, 2005).

Através das críticas originadas com a entrada do feminismo na psicologia surge a psicologia feminista que critica as práticas tradicionais formulando uma atuação profissional comprometida de forma política e social com a condição de gênero e enfrentando-a para proporcionar as mulheres a possibilidade de enfrentar as opressões impostas a elas, se conhecendo e empoderando.

0 presente estudo teve como objetivo geral compreender a condição de gênero e como ela afeta a saúde mental da mulher e identificar o papel da psicologia nas relações de gênero. Para tanto foi estabelecido como objetivos específicos: a) Compreender de forma histórica e social da condição de gênero; b) Identificar os fatores nessa condição de gênero que influenciam a saúde mental feminina; c) Descrever o papel da psicologia diante das relações binárias de gênero apresentando a psicologia feminista.

A justificativa para o desenvolvimento deste trabalho está relacionada ao fato de a autora ter interesse na compreensão de como o estigma social de ser mulher afeta a existência individual, a construção social que estabelece o que é ser mulher definindo padrões sociais e individuais a serem desenvolvidos. Além de marcar e oprimir as mulheres na cultura ocidental mostrando um padrão de sofrimento psíquico decorrente dessa construção, que é relacionado apenas a individualidade quando na realidade é uma condição social da condição do gênero feminino. Com o intuito de trazer essa compreensão para a Psicologia formulando a necessidade de pensar essa condição de gênero e seus efeitos na saúde mental de mulheres.

Este trabalho possui contribuições para a sociedade, academia e ciência. Essa pesquisa bibliográfica contribuirá com conhecimento sobre o assunto ao desenvolver conhecimento teórico sobre o tema que muitas vezes é esquecido durante a academia, refletindo sobre o sofrimento psíquico originado da condição de gênero e o papel da psicologia dentro das relações de gênero. A relevância para a comunidade 
científica essa pesquisa contribuirá com informações que completam os resultados de pesquisas realizadas anteriormente sobre a definição de gênero, o efeito da condição de gênero sobre as mulheres, sofrimento psíquico e a psicologia feminista. Após a leitura desse trabalho espera-se que os leitores compreendam a importância de um assunto que atravessa a vida de todos e tem grandes efeitos sobre a saúde mental e que reflitam sobre a condição de gênero, desconstruindo assim uma hierarquia de gênero que oprime e que gera sofrimento.

\section{REFERENCIAL TEÓRICO}

\section{Condição de gênero}

O conceito de gênero surge com o movimento feminista como uma categoria que descreve as interações sociais, diferente da definição anterior que se limitava apenas ao determinismo biológico implícito, reduzindo a análise do indivíduo às diferenças biológicas, do corpo, ou seja, as genitálias. A diferença entre sexo e gênero gerou as distinções de papéis sexuais e de gênero, o sexo não se refere apenas ao biológico ou a sexualidade, este refere-se aos corpos de mulheres e de homens como mediador das relações de poder de gênero (FÁVERO; MARACCI, 2016).

Senkevics e Polidoro (2012) abordam que a ciência biológica através dos estudos dos genes, anatomia e os hormônios não explica as características da cultura, não há nenhuma ligação com o biológico e as escolhas e comportamentos referido a condição de gênero. Isso não despreza a importância das disciplinas de genética e da psicologia do comportamento, mas sim faz uma consideração de que não existe esse fator que generaliza essas características aos fatores biológicos. Mas não há o reconhecimento de que o determinismo biológico constrói uma essência feminina e masculina, o ser homem e o ser mulher é aprendido através da socialização dos papéis sexuais, sendo incorporados papéis pré-definidos em pela sociedade.

Zanello, Fiuza e Costa (2015) apresentam que existia uma dicotomia entre sexo e gênero. O sexo refere-se as características biológicas ao corpo, o gênero as características socioculturais de caráter e comportamento do indivíduo. Há diferentes formas de entender as construções sociais sobre os corpos femininos e masculinos, para os autores o corpo é uma interpretação social do sexo. A espécie humana possui um corpo biológico e um corpo social que está em permanente diálogo. 0 corpo faz parte de um campo de possibilidades culturais e estas afetam a forma de expressar com corpo, ou seja, o gênero. Fernandes (2009) diz que o mundo social constrói o corpo como realidade sexuada onde é depositado princípios e características das divisões sexuais.

As interpretações, usos ou conclusões biológicas servirem de apoio para ideologias sexistas, machistas ou homofóbicas, a biologia estará, imediatamente, equivocada. Os corpos são objetos da prática social, estes se formam em estruturas sociais e possuem trajetos pessoais. 0 corpo feminino e o masculino representam seu gênero em diversas instancias da sociedade como na política, no mercado de trabalho, no esporte, na mídia, na moda, em casa no setor privado e em sua individualidade, expressado as características de ser homem e ser mulher. É inaceitável que o determinismo biológico reproduza posturas discriminatórias, para isso é necessário que o corpo seja compreendido por uma perspectiva interdisciplinar, reconhecendo suas facetas socioculturais e políticas (SENKEVICS; POLIDORO, 2012).

Segundo Zanello, Fiuza e Costa (2015), a palavra gênero refere-se à rejeição do determinismo biológico, gênero define os aspectos relacionados a normas de feminilidade e masculinidade. É necessário separar os estudos de gênero dos de sexo e sexualidade, o gênero é uma categoria social construídas através das diferenças do corpo sexuado, gênero é relacionado a estudo das coisas das mulheres. Pinheiro (2012) apresenta que os estudos de gênero estudam homens e mulheres separados é impossível, pois os papéis de gênero são impostos e pertence a um funcionamento social.

Em uma sociedade marcada pelo binarismo em que o gênero é um fator estruturante em que para torna-se pessoa é preciso torna-se mulher ou homem. 0 gênero faz parte da cultura e participa e configura os afetos, performances e características sociais que define quem deve ser e como ser quem é, como devem expressar as suas emoções (ZANELLO, 2018).

A construção de gênero é ideológica que constroem a feminilidade e a masculinidade como opostas, e essas diferenças são ditas como naturais, influenciam no comportamento e pensamentos dos indivíduos, afetam as relações sociais e criam estruturas poder social (NOGUEIRA, 1999). 
As questões de gênero refletem o modo como diferentes povos, em diversos períodos históricos, classificam as atividades de trabalho na esfera pública e privada, os atributos pessoais e os encargos destinados a homens e mulheres no campo da religião, da política, do lazer, da educação, dos cuidados com saúde, da sexualidade etc (ROHDEN et al., 2009, p.3).

A história da humanidade contribui para a construção do "estereótipo" feminino e masculino. Dentro da história humana é considerado concreto o que a divisão de tarefas e o papel as mulheres e homens ao longo da evolução tem relação direta com essa construção. As mulheres cuidando do lar e os homens do sustento e segurança desenvolveu estereótipos de capacidade e identidades que diferenciam e qualificam homens e mulheres na história que são observados até a atualidade. As imposições da sociedade determinam os comportamentos, atitudes e valores de mulheres e homens (CRUZ, 2009).

A definição de gênero presente nas mídias e em textos que orientam as políticas públicas teve origem no movimento feminista em suas teorias e em pesquisas de diversas áreas como história, sociologia, ciência política, antropologia e recentemente a psicologia (ROHDEN et al., 2009).

Zanello e Silva (2012) explicam as mudanças que o termo sofre no decorrer da história que antes era conceituado com o estudo das mulheres e suas particularidades, tornou um termo mais relacional, utilizando a expressão relações de gênero com destaques nos valores e papéis sociais associados a mulheres e homens.

Butler (2018) aborda que o gênero é uma forma de organizar socialmente os sexos e não apenas uma interpretação cultural dos mesmos. A percepção do corpo e do sexo é definida pela cultura, conceituando sexo a partir do conceito de gênero. 0 gênero não é apenas uma construção social definida a partir da diferença sexual, a diferença sexual é uma construção de gênero através das possibilidades culturais.

De acordo com Senkevics e Polidoro (2012), o gênero não produz as diferenças fixas e naturais de ser homem e mulher, este formula os significados para as diferenças. O corpo incorpora a cultura, e é compreendido a partir do contexto histórico e socioculturais em que este corpo está inserido.

Segundo Butler (2018), a divisão performativa binária de gênero, constituído no sentido em que só existe a partir do momento da sua expressão, a partir desse pensamento compreende-se que o gênero não está ligado a uma essência de um determinado corpo, mas sim construído a todo momento pela repetição de uma performance estilizada de feminilidade e masculinidade. A teoria dos papéis sociais não comtempla as diferentes formas de ser mulher e ser homem e utiliza de uma perspectiva originadas das relações de poder, seja de gênero, raça ou classe (SENKEVICS; POLIDORO, 2012).

As performances de gênero, ou seja, os padrões comportamentais e emocionais definidos para cada gênero, define binariamente o que ser mulher e o que é ser homem. De acordo com Zanello, Fiuza e Costa (2015), a experiência de gênero é alterada conforme os valores culturais presentes na sociedade que o indivíduo vive. Eles atuam como uma interpretação para os indivíduos, de si e dos outro ao seu redor e quando o assunto é sofrimento psíquico a performance de gênero não deixa de ser relevante esta também é fundamental para compreender o sofrimento psíquico pois é relevante para sua construção.

Segundo Zanello, Fiuza e Costa (2015), a construção social contém um estereótipo fortemente enraizada em um mundo simbólico que foge do controle. E este sustenta a relação de poder hierárquico de gênero, que permeia as desigualdades construindo espaços diferentes destinados a determinado gênero.

De acordo Rohden et al., (2009), existem vários exemplos sobre a hierarquia de gênero nos diversos contextos sociais, esta coloca o homem como superior, ao afirmar que as mulheres são mais sensíveis e com menor capacidade para liderar diferente dos homens que são mais lógicos e melhores para o comando. Essa inferioridade feminina é socialmente construída ao longo da história. Senkevics e Polidoro (2012) apresentam que as masculinidades e feminilidades surgem através dos conceitos da construção social do masculino e feminino estabelecendo assim um conceito de gênero, homens e mulheres são categorias sociais e culturais construídas historicamente através de símbolos, práticas e características que definem o que pertencem ao universo feminino e masculino.

Os papéis e valores atribuídos aos gêneros são antes de tudo relações de poder. Na sociedade ocidental ou oriental, a cultura é marcada pelo sistema patriarcal, onde a mulher é historicamente colocada à margem da sociedade. Segundo Zanello e Silva (2012), ainda que refletir sobre gênero é desnaturalizar as diferenças que existe e são dadas como certas, romper com a definição apenas biológica, levando a reificação do tema. Fávero e Maracci (2016) utiliza os papéis de gênero como forma de compreender as 
influências sociais e culturais presentes na categoria gênero, que irá justificar a adoção de determinados papéis.

Os papéis sociais e sua importância e funcionalidade dependem da época e cultura. Para as mulheres foi necessário avançar várias épocas para que emergisse a obrigatoriedade de se escrever a história das mulheres e tentar compreender sua passagem pelo mundo. A imagem associada à mulher ao longo da história é de inferior ao homem sempre, colocando como suas funções o cuidado, o amor e ser bonita (CRUZ, 2009).

Dentro de uma cultura com alicerces patriarcais os valores e ideais que categoriza o ser mulher e ser homem são diferentes. As categorias valorizadas nas mulheres percorrem três eixos o da renúncia sexual, características de cuidado e renúncia e beleza estética. Já os homens as categorias valorizadas são a virilidade sexual e o laborativa, ou seja, o comportamento de provedor e mantedor (ZANELLO; FIUZA; COSTA, 2015).

Essas diferenças não possuem apenas efeitos simbólicos, mas também efeitos materiais como a pressão estética que exige que meninos sejam musculosos e a menina muito magra e com curvas nos lugares e tamanhos certos. Estimulando práticas sociais como a maternidade em mulheres e está voltada completamente para mulheres um mercado e características de comportamento que condiciona apenas as mulheres pois estas engravidam e tem toda a sua construção social voltada para essa reprodução e para cuidar dela (SENKEVICS; POLIDORO, 2012).

De acordo com Rohden et al (2009), a forma com as mulheres e homens se comportam de sociedades é resultado de um aprendizado intenso sociocultural em que são ensinados a agir e se comportar conforme seu gênero. Existe uma expectativa social sobre a forma de ser mulher e ser homem, como falar, agir, andar, amar, trabalhar e entre outros.

A diferença entre homens e mulheres é nítida nos contextos privados e públicos, com um padrão de comportamento, sentimentos e valores distintos fazem com que as mulheres tenham uma significativa desvantagem em relação aos homens no âmbito público com cargos destinados para homens e mulheres, e as mulheres sempre colocadas como inferiores e sendo geralmente excluídas do mercado de trabalho (CRUZ, 2009).

De acordo com Senkevics e Polidoro (2012), a complexidade social presente em na espécie humana apresenta uma extensa rede de relações sociais com construções de sentidos e significados complexos que formam as estruturas de poder, que definem os comportamentos e valores. Não se pode definir que as ações e comportamentos são fruto dos instintos e condição biológica, nem que as construções sociais e culturais formadas pelo contexto histórico cria as características biológicas. As construções socias sobre o corpo, o sexo e o gênero refletem a condição histórica em que é realizado o pensamento cientifico são sustentadas pela biologia.

Segundo Navaz e Koller (2006), foi através do feminismo em especial a 3o onda que problematizaram as categorias consideradas fixas de gênero, essas categorias entende o sexo como como natural, binário e hierárquico, perpetuando a ideia de essencialismo masculino e feminino. Mulheres e homens possuem as mesmas capacidades, não há nada na biologia que determine comportamento e competências, porem mulheres e homens enfrentam circunstâncias diferentes, um destino que é imposto a determinado gênero e criado assim um repertorio de ações para mulheres e homens (NOGUEIRA, 2001).

Homem e mulher são antes de tudo uma categoria política em é necessária uma mudança social para descontruir as desigualdades das relações de gênero (SENKEVICS; POLIDORO 2012).

\section{Ser mulher}

Santos et al., (2016) define gênero de forma mais geral, tem sido compreendido como produto de representação, espaços, características psicológicas e comportamentais e até as expectativas que são determinadas para homens e mulheres de formas diferentes a partir da condição e diferença biológica.

Senkevics e Polidoro (2012), entendem por ser homem e mulher uma série de característica distintas que traz para a masculinidade adjetivos como a virilidade, insensibilidade e agressividade; e para a feminilidade o sentimentalismo, submissão e instabilidade emocional. Essa caracterização de gênero está presente em diversos aspectos do desenvolvimento humano, desde a infância fazem parte das brincadeiras, os meninos brincam simulando guerras, lutas e heroísmos em quanto as meninas brincam de 
boneca, casinha e beleza que simulam as tarefas de cuidado e vaidade. Essas características são ensinadas e constroem assim os comportamentos que definidos para ser homem e mulher.

De acordo com Rohden et al., (2009), gênero significa que mulheres e homens são produtos da realidade social que estão inseridos e não algo natural através das diferenças corporais. As mulheres devido a capacidade de reprodução são relacionadas a natureza e devido a essa condição em diversas culturas é relacionada a fragilidade e destinadas sempre a maternidade.

A construção da imagem feminina a partir da natureza e das suas leis implica em qualificar a mulher como naturalmente frágil, bonita, sedutora, submissa, doce, etc. Aquelas que revelassem atributo opostos seriam consideradas seres antinaturais. No organismo da mulher, em sua fisiologia especifica, estariam inscritas as predisposições ao adoecimento mental (ZANELLO, 2018, p. 21-22).

Essa visão construía a ideia de que a natureza determinava uma ordem de sexos que coloca a mulher em um lugar inferior ao homem, esse lugar é fundamentado pela ciência e a sociedade deve respeita-lo em todos as esferas sociais. Ao pensar em gênero, em mulheres e homens é necessário compreender essas categorias mutáveis, não só apenas no binarismo, mas também está subjetivada e interiorizada em cada indivíduo (SENKEVICS; POLIDORO, 2012).

Os valores e estereótipos que existem no binarismo não são questionados são apenas vividos de forma intuitiva, estes participam ativamente no processo de sofrimento psíquico, esses afetos e comportamentos podem ser percebidos como sintomas (ZANELLO, 2019).

De acordo com Alves (2017) nascer mulher dentro de uma cultura patriarcal é viver o primeiro nível de opressão, a condição de vida das mulheres por mas que tenha passado por mudanças ao longo da história como a entrada das mulheres no mundo do trabalho e a conquista de direitos contra a cultura de domínio e controle, ainda existem muitas desigualdades na experiência de ser mulher, esse nível de opressão pode aumentar devido a soma das demais marcas sociais pois essa cultura opressiva continua firme perpetuando essas desigualdades. 0 patriarcado é uma estrutura de poder político disfarçado de diferença natural, diferenciando homens e mulheres naturalizando caraterísticas que definem socialmente quem é homem e quem é mulher (ZANELLO, 2018).

Navaz e Koller (2006) descrevem que a opressão sofrida pelas mulheres é naturalizada pelo sistema patriarcal que estrutura a sociedade, esse sistema perpetuam a desigualdade entre homens e mulheres dando origem a diversas violências de gênero através da opressão e dominação sobre as mulheres.

Ser mulher significa ser alguém que não pode ser quem é, ou quem deseja ser, é ser educada para servir aos homens. Esse é o papel da mulher servir sem esperar nada em troca, é ser invisível, é ser objetificação e destinada a procriação feita para o alivio do outro. Essa e a verdade natural que o patriarcado impõe a mulher (TIBURI, 2018).

Beauvoir (2016), afirma que não há nenhum fundamento psicológico ou biológico que define o ser fêmea, a definição de gênero é criada na sociedade, são padrões da civilização. A noção binária que se tem é uma estrutura em que o feminino é construído socialmente com leis padronizadas para cada gênero, é descontextualizado politicamente, sendo separado de temas como raça, classe e dos eixos de relação de poder. E complementa afirmando que é necessária uma reformulação da noção de gênero para que essa inclua as relações de poder de forma igualitária.

Segundo Tiburi (2018), ser mulher é uma marcação que traz discriminação, exclusão acarretando em sofrimento, essa marcação vem de todo um contexto histórico em que as mulheres são inferiores e sem voz. E foi através do feminismo que essa posição feminina foi questionada e percebendo a opressão que é marca do gênero. Pinheiro (2012), aborda que as mulheres são agentes ativas na história da humanidade, com uma realidade marcada por opressões e dominação nas relações sociais. 0 feminismo busca desconstruir essas desigualdades impostas pelas relações de gênero que formam discriminações e estereótipos culturais. A frase "biologia é destino" exprime ainda uma ideia muito verdadeira para a maioria das mulheres do mundo, embora a natureza e a condição deste destino possam diferir substancialmente (NOGUEIRA, 1999 p. 7).

A opressão sofrida pelas mulheres é gerada pelo sistema de poder que transforma o sexo biológico em produtos da atividade humana, colocando as mulheres em um lugar inferior e essa noção é naturalizada na sociedade. Santos et al., (2016) mostra que os corpos de mulheres e homens não dão origem as essências e naturezas femininas e masculinas, estes surgem a partir do sistema simbólico que constrói o que é ser homem e o que é ser mulher e seus valores. Segundo Senkevics e Polidoro (2012), é através das diferenças 
percebidas biologicamente entre os sexos, esses símbolos são aprendidos socialmente e afetam vários aspectos da sociedade ocidental como a divisão sexual do trabalho, da educação, da violência e outros aspectos sociais que sofrem a influência das relações de gênero.

A imagem definida como feminina é relacionada a beleza, uma mulher deve ser bonita, magra, com traços simétricos e de preferência branca. $\mathrm{E}$ deve se manter assim independente de qualquer coisa, quando uma mulher não se encontra dentro do padrão ela é considerada menos mulher é inferior. A moralização do corpo feminino ocorre na transformação da estética para os valores éticos, pois o dever moral da mulher é cuidar de seu corpo e ser bela. Essa imposição é vivenciada como uma escolha individual quando na realidade é um modelo que é imposto culturalmente (ZANELLO; FIUZA; COSTA, 2015).

De acordo com Swain (2006), na construção dos papéis de gênero as mulheres são diferentes, sofrendo influência do dispositivo amoroso, o amor é para as mulheres o que o sexo é para os homens, sendo essa a razão do viver destes. A descrição destinada as mulheres é de ser dócil, devotada, delicada, carinhosa e amorosa. Essas exigências sociais aprisionam as mulheres ao desejo de outros, sendo estas condenadas a uma existência de impotência e invisibilidade, vista apenas como uma cuidadora e reprodutora. 0 ser mulher é relacionado a contenção sexual e o exercício de cuidados e amor com o os outros, expressos no desempenho do papel de esposa, mãe e dona de casa.

As emoções de homens e mulheres são padronizadas, adquiridas através de anos de socialização, são construidias nos primeiros anos de vida e são performadas durante toda a vida. Evidendia-se, desta forma, que a cultura é fundamental na formação dessa configuração das emoções (ZANELLO, 2018).

A ligação do universo masculino e a cultura está ligada as características definidas como masculinas como a objetividade, a racionalidade e por ser público e essas definições o colocam em uma posição de superioridade em relação ao feminino que é relacionado a natureza, ligadas ao emocional, subjetivo e um ser privado. As narrativas históricas apresentam um contexto político e público que coloca o homem como herói e como principal representante da história da humanidade, enquanto as mulheres são excluídas quase que por completo como personagens e produtoras da história (GOMES, 2011).

A partir da terceira onda do feminismo houve uma nova compreensão de gênero, com através das contribuições de Judith Butler, na qual afirma a diferenciação sexual é uma construção de gênero o fator biológico é norteado pelas possibilidades culturais (ZANELLO; FIUZA; COSTA, 2015).

De acordo com Garcia (2011), a história das mulheres foi construída pela militância feminista que buscava integra a realidade da vida das mulheres para a ciência. Foi e ainda é urgente retirar o sexo feminino da exclusão, do esquecimento e do privado. A pesar das mulheres serem vítimas de desigualdades e injustiças essas nunca deixaram de fazer parte da história estiveram presentes e participaram das lutas e revoluções ao longo da história, lutas de independência, abolicionistas e trabalhistas. E dentro dessas lutas formularam sua própria luta o feminismo.

Segundo Gomes (2011), as mulheres muitas vezes são excluídas da história, e essa preocupação vem tomando as historiadoras que passam a questionar o papel da mulher na história. Sendo através da apropriação do feminismo no contexto acadêmico a discutir gênero tem ligações diretas com o discurso das relações de poder com o foco nas opressões, violência e invisibilidade das mulheres na sociedade, formulando formas de enfrentamento das desigualdades e de emancipação. Expandindo o tema para discursões de raça, classe e sexualidade promovendo visibilidade as experiências femininas.

Segundo Santos et al., (2016), as mulheres estavam presentes desde as primeiras críticas intelectuais de Aristóteles a Freud na história a dicotomia homem/cultura e mulher/natureza é marcada por estereótipos e preconceitos em uma hierarquia de valores e poder. Essa hierarquia é sustentada pela ideia de desigualdades entre os sexos.

De acordo com Zanello, Fiuza e Costa (2015), para os estudantes de gênero é necessário compreender as mulheres, assim no plural, a ideia de gênero é substituída pelas possibilidades e diversidades de marcadores como raça, etnia, classe social, condição, localidade e sexualidade. Quando se conceitua gênero fica evidente que o sexo biológico ou a genitália não é um fator definidor do comportamento e subjetivação humana. Esses padrões são criados através da cultura é dado assim pois as diferenças genitais através do contato sexual geram outros seres. 


\section{Saúde mental feminina}

De acordo com Zanello (2018), o gênero é um importante determinante social que deve ser considerado na análise e compreensão dos processos de saúde mental. Na área da saúde mental que a vivência individual é atravessada pela condição de gênero e a saúde mental é afetada por esta, a própria experiência de um transtorno mentais é vivenciada de forma diferente para homens e mulheres. A autora ainda aborda que o homem era relacionado e identificado com à racionalidade a mulher era relacionada $\mathrm{e}$ identificada com uma figura insana, colocando a loucura em uma dupla polaridade uma como um dos erros das mulheres e as vezes visto como parte da essência feminina, a loucura quando experimentada por homens é representada de forma simbólica como feminina (ZANELLO; 2018).

A Ciência por muito tempo perpetuou essa divisão na compreensão da saúde mental e a medicina é exemplo de como a ciência colaborou por muito tempo com a construção e cristalização das relações de gênero, confirmando um padrão de comportamento gerado baseado nas diferenças corporais. Na medicina as mulheres eram inferiores, homens imperfeitos, os estudos de anatomia eram construídos na ideia de que os órgãos sexuais e reprodutivos femininos eram um pênis investido e por isso elas eram inferiores. A ciência afirmava que a natureza já havia dividido os corpos e os diferenciados agora o que restava era seguir (FERNANDES, 2009).

O sistema de atenção à saúde mental muitas vezes acaba por reforçar os papéis sociais de gênero e estigmatizar as condutas que vão contra o modelo patriarcal, o que torna as questões de gênero presentes no adoecimento psíquico invisíveis. Zanello, Fiuza e Costa (2015) ao refletirem sobre o uso de um pressuposto epistemológico feminista aponta mudanças no campo da saúde mental, mudanças no acolhimento e nas estratégias de intervenção e tratamento.

Em 2001, a OMS contrariou um modelo de explicação predominantemente biológico e reconheceu a importância de aspetos sociais ("diferenças entre os sexos") na configuração dos processos saúde-doença mental. Numa relação dialética com a dimensão biológica, o adoecimento é produzido também socialmente e isto é particularmente visível a partir de uma vulnerabilidade social feminina, haja vista que, desde uma perspectiva tradicional, a saúde mental das mulheres foi historicamente concebida estando relacionada com o seu aparelho reprodutor através de aspetos como a gravidez, o parto, o puerpério, o climatério etc (ALVES, 2017, p.4).

Com a falta da compreensão de gênero dos profissionais de saúde faz com que os serviços de saúde mental façam uma intervenção universal e indiferente a todos, não considerando fatores que como já vimos são significativos para a saúde mental e o gênero é um desses fatores. A vivência feminina é diferente da masculina por tanto o sofrimento psíquico em mulheres será diferente que em homens (ALVES, 2017).

Alves (2017) aborda que a construção de um novo modelo para a ciência que compreende a saúde mental das mulheres visualiza a condição das mulheres como de uma existência opressiva, essa opressão faz parte do cotidiano das mulheres e constrói forma de adoecimento específica para mulheres.

Conforme Zanello (2018) ao longo da história o sofrimento mental e a loucura foram objetificações na falta de razão, com a voz das mulheres silenciadas sem a capacidade de falar sobre si, a história psiquiátrica é composta de discursos de psiquiatras homens sobre a loucas mulheres, a abundância de exemplos femininos para casos psiquiátricos não é um acaso. A mesma autora comenta que o manicômio, como casa do desespero, deve ser entendido como símbolo de todas as instituições criadas pelos homens, do casamento à lei, que confinaram e confinam as mulheres, e as deixam loucas (p. 20).

Entre as patologias que atravessa a vivência feminina está a depressão que é apontada como uma condição da existência feminina, pois esta é marcada pelo silenciamento e a impossibilidade de expressa-se, implodido e gerando sofrimento psíquico relacionado a condição de gênero (ZANELLO; FIUZA; COSTA, 2015). De acordo com Cruz (2009), a compreensão da depressão e como afeta as mulheres através das relações de gênero. Dentro da comunidade cientifica procura-se explicar o sofrimento e adoecimento mental como pertencente a um único fator, mas sim com diversos fatores. 0 estudo do sofrimento mental é complexo pois é fundamental estudar os diversos contextos da vida humano como a cultura, a biologia, o social, o subjetivo e o período histórico. A autora completa afirmando que o gênero atravessa todos esses contextos a experiência de ser mulher e homem são diferentes e devem ser levadas em conta na compreensão do sofrimento e adoecimento mental.

As desigualdades de poder tem um peso significativo na saúde mental de mulheres, pois essas colocam as mulheres em um lugar abaixo dos homens, com papéis sociais voltados para o cuidado do outro, ser mãe, doméstica e se manter bela para o outro, isso somado ao trabalho público gera um expectativa muito 
grande sobre as mulheres o que a faz sentir-se cada vez mais incapaz além de colocar a mulher vulnerável a diversos tipos de violência (ALVES, 2017).

\section{Sofrimento psíquico de gênero}

Segundo Zanello, Fiuza e Costa (2015), o sofrimento psíquico é uma experiência constituída socialmente e são moldados segundo os valores e normas de gênero, com desigualdades entre homens e mulheres que geram sofrimento psíquico. Já Santos (2009) concorda e completa afirmando que o sofrimento psíquico parecer ser algo individual um conjunto de mal-estar subjetivo é na verdade uma experiência construída socialmente através dos valores e normas sociais, e o gênero está nessa construção, o sofrimento psíquico será configurado através das vivências de cada indivíduo como mulheres ou homens com padrões para cada um destes.

Apesar das vivências de sofrimento e adoecimento principalmente o mental serem considerados uma vivência extremamente individual, estes expressam fatores presentes em na construção social de valores. Santos (2009), ao problematizar gênero fica claro a necessidade de analisaras as relações de poder de gênero para assim compreender os efeitos desses no adoecimento das mulheres, sofrimento que tem sua origem no âmbito público é uma condição coletiva e não individual.

Os resultados da pesquisa de Zanello, Fiuza e Costa (2015) apontam que a experiência do adoecimento é gerada colocando mulheres e homens de forma diferente, com sofrimentos diferentes e característico de seu gênero. Os valores determinados a gêneros que está engendrado culturalmente, são tomados para si pelo indivíduo como forma de julgamento e valoração. 0 discurso de homens e mulheres revela que os fatores que geram sofrimento psíquico têm origem nos estereótipos de gênero. A fala das mulheres sobre seus sofrimentos tem base nos estereótipos de gênero, marcada por relações com a maternidade, casamento, vida amorosa, padrões de beleza, o valor que as mulheres dá a si é feito pelo olhar do outro, esta permanece em um lugar de silêncio e obediência que domina a existência feminina.

Zanello (2019), ao estudar gênero é fundamental compreender como a cultura sustenta a hierarquia que vulnerabiliza determinado grupo que pode gerar sintomas de sofrimento nesses. Para a perpetuar essa hierarquia é criado um processo dos afetos e das emoções, performances comportamentais de gênero que atravessa a vivência indivíduo.

A cultura ocidental afirma que o destino da mulher é a família, sua existência é destinada a cuidar dos outros, e está fora desse ideal quando a mulher que não aceita esse destino é considerada uma violação social e uma desnaturalização. Esse ideal é definido como dispositivo amoroso, mecanismo de subjetivação que constrói corpos-em-mulheres para que estas estejam sempre prontas a se sacrificar e colocando sua própria vivência em esquecimento e vivendo para outros (SWAIN, 2006).

Segundo Fernandes (2009), através do determinismo biológico foi construída como função social das mulheres e suas características foram limitadas a reprodução, a natureza, a fragilidade, ao cuidado e submissão. Pois era a interpretação de seus corpos.

Essa hierarquia cria estereótipos e estigmas de gênero definido por Goffman (2008) como uma referência a uma característica muito depreciativa, algo que o separa dos demais indivíduos classificando os mesmo em bons ou maus. 0 termo estigma, portanto, será usado em referência a um atributo profundamente depreciativo, mas o que é preciso, na realidade, é uma linguagem de relações e não de atributos. Um atributo que estigmatiza alguém pode confirmar a normalidade de outrem, portanto ele não é, em si mesmo, nem horroroso nem desonroso.

Segundo Zanello (2019), os comportamentos ditos masculino e feminino em que há um padrão distinto de ser, essa forma binária e essencialista coloca o homem em uma posição de superioridade devido a sua força, lógica e masculinidade. Já as mulheres são colocadas em um lugar de inferioridade por ser considerada frágil, emotiva, dócil e cuidadora. Esses padrões de comportamento devem ser seguidos e são ensinados desde o nascimento, a experiência de gênero é destinada a cada indivíduo desde o momento que os olhos são abertos, fechando assim as possibilidades de escolhas e experiências, o distanciamento deste padrão mesmo que mínimo é fortemente reprimindo socialmente, gerando discriminação e violência. Essa construção social da origem as relações de poder e faz do gênero um marcador da desigualdade social, gerando diversos problemas sociais e um deles é a inferioridade da mulher em relação ao homem que coloca está em uma posição de vulnerabilidade.

De acordo com Alves (2017), várias vezes as diferenças entre mulheres e homens já foram escritas e estudadas, as diferenças biológicas são nítidas e incontestáveis, porém os novos estudos não foca mais em 
diferenças biológicas, os novos estudo incluem as noções de gênero, entram no campo social, cultural e psicológico, e estes são os fatores influentes para regular e distinguir mulheres e homens de forma objetiva e subjetiva. Cruz (2009), análise do gênero auxilia a compreensão do fenômeno da doença mental, considerando as experiências particulares do sofrimento psíquico de cada sujeito, não esquecendo nenhum contexto em que este vive.

Os ideais de gênero fazem parte da construção do sofrimento psíquico, a definição do que é ser mulher é um limitador da existência e da individualidade e facilita o desenvolvimento de sofrimento. Seguindo esse pensamento é fundamental que pensar em estratégias de intervenção em saúde mental que compreendam e analise as especificidades das diferenças de gênero e o sofrimento psíquico desencadeado por estes (ZANELLO; FIUZA; COSTA, 2015).

\section{Psicologia feminista}

De acordo com Garcia (2011), a ciência tem a tarefa de construção de modelos que criam uma ordem dentro da sociedade, na sociedade ocidental, a ordem é feita à custa do diferente, e o diferente na cultura patriarcal é representada pelo feminino, a mulher é o outro do homem. Este pensamento foi usado como desculpa para excluir as mulheres das estruturas de poder. Como oposição a essa estrutura patriarcal opressora é que surge o feminismo. 0 feminismo é ainda é um tema novo e pouco recorrente em pesquisas. Os temas que envolvem gênero são poucos e descredibilizados e em psicologia é colocado a neutralidade da ciência em jogo, como descrito por Nogueira (1999, p.11):

$\mathrm{Na}$ psicologia assistiu-se sempre a uma grande resistência relativamente à aceitação das críticas feministas no que diz respeito aos paradigmas teóricos, possivelmente devido à ênfase positivista que dominou a disciplina, e que se fundamentava na neutralidade e na objetividade.

Na ciência o conhecimento era marcado por um ideal androcêntrico, ou seja, a padronização dos comportamentos, pensamentos e experiências era as associadas ao masculino assim assumindo o masculino como o único, esse termo é intimamente ligado ao patriarcado. Esse ideal começou a ser questionado na academia o que deu origem a uma nova perspectiva das metodologias e conceitos da psicologia, e assim desenvolvendo uma nova abordagem da ciência, voltada para a compreensão e análise das relações entre mulheres e homens. É através que do ativismo acadêmico e político surge à psicologia feminista, a partir do reconhecimento do estado de ausência das mulheres, que estas e suas experiências e problemas deveriam ser integrados na prática, teoria e investigação cientifica (NEVES; NOGUEIRA, 2003).

De acordo com Navaz e Koller (2006), a recusa para acrescentar a perspectiva política por uma construção elitizada de homens brancos nos espaços de poder e por consequência os espaços acadêmicos, para que a ciência possa compreender a vivência humana e a vivência feminina é necessário romper com essa perspectiva.

De acordo com Zanello (2018), as diferenças sexuais anatômicas só se tornaram interessante no século XVIII quando essas diferenças começaram a se tornar politicamente importantes. Na consolidação do capitalismo a transformação social constituiu um lugar especifico para as mulheres, e estes especifico para cada classe, criando assim um padrão de função da feminilidade que ainda está presente atos dias de hoje. A função da feminilidade é de sustentar a virilidade do homem, a ideia de submissão feminina como função da mulher, com a responsabilidade de cuidar e agradar a outros como o destino natural do sexo feminino.

Senkevics e Polidoro (2012) apresentam as concepções cientificas de corpo, sexo e os papéis desenvolvidos deles, nunca estiveram livres dos juízos de valores pertencentes a cultura. No século XIX as ciências médicas compreendiam o corpo feminino como incompleto, adoecido e instável, as mulheres eram consideradas "homens invertidos", existiam explicações que descreviam as genitálias femininas como uma versão invertida e imperfeita da genitália masculina, a partir dessa inferioridade justificavam a inferioridade feminina. E foi a partir desse período foi constituída a noção de que o ser humano é uma espécie bissexuada entre dois sexos que é reconhecido atualmente.

As ciências humanas vêm travando uma disputa com as ciências biológicas para desconstruir as afirmações biologistas. Por mais que exista um interesse em interpretar os aspectos biológicos considerados naturais e imutáveis há também o adentrar de movimentos sociais crescente na ciência entre esses o movimento feminista e LGTQIA+ que reivindicam uma postura científica que atenda e compreenda gênero e sexualidade, construindo assim uma sociedade mais justa e igualitária, e para isso é 
necessário desconstruir a naturalização das hierarquias e desigualdades sociais, este é um papel fundamental da ciência (SENKEVICS; POLIDORO, 2012).

Os estudos de gênero e feministas estão se desenvolvendo nas diversas áreas de ciências humanas e sociais no Brasil, consolidando estes como um campo de pesquisa amplo. As produções feministas possuem um caráter crítico e emancipatório, com o objetivo de libertar as mulheres oprimidas com a desigualdade de gênero. 0 feminismo problematiza os eixos que oprimem que estão estruturados na sociedade, buscando igualdade entre os gêneros. Os estudos de gênero ganharam força através da interdisciplinaridade entre a literatura, antropologia e psicanalise permitindo assim uma compreensão para o feminino em seus vários aspectos como social, subjetividade, representação e práticas, assim descontruindo o determinismo biológicos que definia as relações de gênero (GOMES, 2011; SANTOS et al., 2016).

Segundo Senkevics e Polidoro (2012), os estudos de gênero e de reprodução são fundamentais para a ciência já que para muitas espécies de seres vivos é necessário a reprodução sexuada para a perpetuação da espécie. Nessas espécies ocorre o dimorfismo sexual que é uma série de características anatômicas, órgãos, hormônios e comportamentos oferentes destinados a cada sexo masculino e feminino. Na espécie humana não é diferente busca-se qualidades e característica para diferenciar os sexos, naturalizando alguns aspectos e responsabilizando a biologia pelas diferenças entre homens e mulheres através da concepção do corpo e suas particularidades não considerando os aspectos culturais, sociais e políticos para essas distinções entre mulheres e homens.

0 desconforto que as relações e papéis de gênero causam nas mulheres, estas buscaram na ciência as respostas criando assim a possibilidade de contestar esses papéis em diversas esferas das pesquisas acadêmicas, com o objetivo de desconstruir as diferenças entre homens e mulheres. Isso não é diferente para a psicologia, esta cunhou a palavra gênero como construção social (ZANELLO, 2018).

Segundo Garcia (2011), a perspectiva de "gênero" está em crescimento, presente em pesquisas e nos trabalhos científicos. Não é negado o enfoque em temas de "gênero" e sua importância, porém é comum que a palavra feminismo assuste e incomode nas pesquisas, e em ambientes públicos e privados. Como se a palavra feminismo fosse perigosa, e para isso usar a palavra "gênero" é mais aceito. 0 motivo é que o feminismo ao longo da história foi tratado como um inimigo e que deve ser combatido, e isso contribuiu para que o feminismo continue até a atualidade sendo uma palavra que assusta e ausente nas pesquisadas, nas organizações de trabalho e nas políticas públicas.

Os estudos de gênero se consolidaram no Brasil nos anos 70, nos anos 80 as produções acadêmicas sobre gênero cresceram e se diversificaram, concentradas na antropologia, sociologia, história, literatura, psicanálise, psicologia, política, saúde, direito, educação, comunicação, artes, geografia e economia. Nos anos 90 começaram a surgir núcleos de estudos e pesquisas sobre as mulheres aumentando as publicações com esse tema (NAVAZ; KOLLER, 2007).

Na perspectiva do Gomes (2011), os estudos de gênero que buscavam preencher o vazio e passaram a investigar as mulheres como sujeitos históricos, como objetivo de compreender a condição feminina, analisando o cotidiano e mentalidade das mulheres, as temáticas de sexualidade, amor, medo, corpo, cuidado, as relações público e privado ganharam destaque na análise do feminino, tornando assim as mulheres sujeitos sociais que fazem parte da história.

Em todo o mundo o feminismo empunham a luta das mulheres contra todas as formas de opressão de gênero, essa luta tem se posicionado contra a dominação nas relações de gênero, lutando pela contra a dominação das relações de gênero e pela emancipação feminina, lutando por um mundo com direitos iguais para homens e mulheres. Pinheiro (2012) descreve sobre a diferença entre os gêneros gerou a discussão decisiva para a própria psicologia feminista.

De acordo com Pinheiro (2012), o feminismo surge como movimento social com objetivo de fazer frente ao sexismo, denunciando as práticas sexistas, práticas que fazem das pessoas pertencentes a determinado sexo possam sofrer com discriminação e terem seus direitos humanos violados através da falta de liberdade e uma realidade de violência. 0 movimento feminista surgiu na ciência como questionamento a respeito dos modelos teórico que eram seguidos na ciência, principalmente as relações sociais e a psicologia ciências em que o movimento feminista adentra. Povoando revisões em sua metodologia e conceitos criticando de forma cientifica os sujeitos e suas relações com o gênero. Segundo Prenh e Müning (2005), o feminismo surge como movimento de mulheres que lutam por direitos é também um fundamental campo teórico, muito fértil em suas problematizações. 
De acordo com Prehn e Hüning (2005), a segunda onda feminista é conhecida como a empirista, pois é quando surgiram as primeiras críticas visando a exclusão do pensamento sexista e androcêntricos presentes na psicologia; e a pós-modernista é a atual as vozes feministas na psicologia. No século XX o movimento feminista ressurgiu como um movimento social de grande importância, que questiona modelos teóricos seguidos nas mais diversas ciências, principalmente as que estudam as relações sociais. E a Psicologia é um dessas ciências, e na psicologia o impacto do feminismo tem sido muito significativo, provocando mudanças e revisões de metodologias e conceitos e levando a ciência a buscar novas formas de analisar e abordar os indivíduos e suas relações.

A psicologia sempre teve resistência à aceitação das críticas feministas, por ser uma ciência que busca a neutralidade e ser feminista é trabalhar em defesa do interesse de um grupo, assim a psicologia feminista seria a perca da neutralidade da ciência (NOGUEIRA, 1999).

O movimento feminista ao entra na psicologia questionou suas afirmações que antes estava presa em um ideal positivistas que possuía como concepção de sujeito a perspectiva como ser autônomo, racional e senhor da natureza e este é representado pelo homem branco e burguês. Prenh e Müning (2005), apresentam que a ciência positivista tem como ideal de racionalidade e objetividade a neutralidade que não considera a subjetividade e as lutas políticas como critério científico. Ao assumir posição política essas pesquisas parecem ir contra a ciência e as psicoterapias. Ao perpetuar a ciência como apolítica acabam por colocar as práticas a serviço da dominação patriarcal.

Para Nogueira (2001), as feministas na psicologia desafiaram todo o conhecimento sobre gêneros divergindo da ciência tradicional, questionaram os resultados de pesquisas anteriores, contribuindo para um novo pensamento sobre gênero, sobre ser mulher. Essa união do movimento feminista com a psicologia afirma que homens e mulheres sofrem influência social em suas construções socias e suas realidades são diferentes. 0 movimento feminista propôs a necessidade de considerar os interesses de determinado grupo em vez de assumir uma neutralidade, pois a ciência deve ser centrada no indivíduo e em seu contexto social, mas sempre considerando as construções coletiva da subjetividade.

Zanello (2019), para compreender o gendramento que acontece no processo de subjetivação é fundamental e compreender a cultura em que o sujeito está inserido, pois é através desta que são criados, mantidos e perpetuados a hierarquia de poder. Muitas vezes os cientistas reproduzem as "verdades" sobre a condição de gênero, reproduzindo crenças e valores de gênero, assim reproduzindo a desigualdade.

Os estudo feministas contribuíram para o alargamento da visão das ciências sociais, dentro da psicologia apresentam novas perspectivas. Nas décadas de 1960 e 1970 surgiu os estudos feministas com o objetivo de desconstrução do feminino, a ideia de essência feminina e das desigualdades sociais a invisibilidade das mulheres (ZANELLO; FIUZA; COSTA, 2015). Os estudos de gênero possuem dois aspectos são estes a promoção da mudança nas concepções de papéis de gênero a importância de desafiar e distinguir as esferas público privada, em quais são sustentadas as relações de gênero (FÁVERO; MARACCI, 2016).

Com o estudo das relações de gênero e a saúde mental ainda está no começo, o questionamento de como esse processo de subjetivação gerada tem efeito na saúde mental do indivíduo ainda é um campo novo para a ciência, quanto a estudar o sofrimento psíquico. Segundo Zanello (2019) os estudos sobre as mulheres ainda são vistos com grande desconfiança sendo estes apenas tolerados ou marginalizados para a ciência pois acabam fugindo da imparcialidade que é tão desejada na ciência, cabe as mulheres cientistas estudar seu próprio sexo.

Para Prenh e Müning (2005), na psicologia as feministas reconheceram o sexismo no desenvolvimento de pesquisas e estudos, reivindicaram uma expansão na pesquisa para incluir as experiências das mulheres e a necessidade de estudar as consequências que a opressão sofrida pelas mulheres na estrutura patriarcal para o desenvolvimento pessoal e social da mulher. Essa perspectiva feminista trouxe novos conceito e problema para gênero e as relações de poder, temas raciais e de classe também tiveram mais visibilidade. A psicologia ao adentrar no feminismo assumiu uma preocupação com o público e com o social, uma abordagem política da ciência.

Segundo Neves e Nogueira (2003), as investigadoras feministas usam a pluralidade como principal método para defender e respeitar a subjetividade e especificidade de cada indivíduo, estas construídas no social. O legado feminista para a ciência é aliar a singularidade individual e as expressões culturais, e os contextos político e social. A utilização de diversas metodologias para compreender os fenômenos sociais e psicológicos é um avanço e benefício para a ciência.

De acordo com Zanello, Fiuza e Costa (2015), a psicologia feminista percebeu a necessidade de pensar o ser mulher além das tendências essencialistas que limitam os gêneros a padrões únicos, e abrindo para as 
novas possibilidades, e estudar mulheres e homens separados. Desde a afirmação da psicologia como ciência as relações entre mulheres e homens e sua identificação na sociedade tem sido alvos de suas pesquisas com pontos de vista diferente. Na psicologia são considerados três períodos no modo de idealizar a mulher, o homem e as relações entre esses.

O primeiro período é marcado pela ausência e inferioridade da mulher, tanto como pesquisadoras e como sujeitos na pesquisa. 0 segundo período corresponde a segunda onda feminista, nesse período as mulheres entram nas academias se tornando pesquisadoras e começam a olhar para si próprias com sujeito na pesquisa, considerando as experiências femininas para dentro da ciência, as investigações geradas nessa época são nomeadas de Psicologia da Mulher; o terceiro período é o atual quando o feminismo entrou na academia, as teorias feministas passaram a estar presentes nas pesquisas e estudos da psicologia, desconstruindo conceito e estruturas arcaicas e opressoras da ciência dando voz as mulheres (SAAVEDRA; NOGUEIRA, 2006).

Ao advogar o princípio da emancipação feminina, totalmente adverso ao regime patriarcal, os/as psicólogos/ as feministas assumem a sua opção pela não neutralidade da ciência psicológica e das suas práticas e politizam os espaços terapêuticos onde se movimentam. Está tomada de posição é particularmente significativa nas situações de violência, uma vez que possibilita que as vítimas vejam validadas as suas experiências pessoais. (NEVES; NOGUEIRA, 2003, p.1)

Segundo Neves e Nogueira (2003), a psicologia feminista tem o objetivo de tentar compreender os efeitos da condição de gênero para a construção de conhecimento. A psicologia feminista crítica e se opõem a visão androcêntrica da psicologia tradicional, criando assim uma visão mais compreensiva e justa da mulher. Os autores afirmam que os valores que desafiam a neutralidade e a universalidade são adotados para a concepção das metodologias feministas e refletem em suas práticas. Diferente da psicologia tradicional a psicologia feminista não usa a padronização sobre os fenômenos humanos, mas si utiliza da visão da diversidade, com experiências distintas para cada indivíduo, analisando de uma forma mais subjetiva.

Essa abordagem vai questionar a centralização do sujeito da razão ou homem nas pesquisas, centralizando os estudos nas mulheres, reconhecendo as relações sociais, em oposição a busca por uma verdade absoluta e universal. Nogueira (2001), vendo o ser humano como parte de um sistema social e cultural em que é construída uma relação de poder através das relações de gênero. Para a psicologia o indivíduo deve ser compreendido em seus estudos como um ser construído socialmente e produto da sua época e cultura, estando presos a um sistema histórico, político, social em que não podem ser retirados e estudados de forma independente, é necessário estudar o todo.

O debate feminista faz uma crítica sobre as relações de poder que fazem parte da construção de gênero, questionando as bases que limitam as condições de gênero. Anjos e Lima (2016), descrevem que quando o feminismo entrou na psicologia observou-se que não é possível estudar o ser humano de uma forma neutra e assim assumir uma abordagem ativa socialmente e politicamente é fundamental, para que assim incluir todos de forma completa.

Toda atividade humana é política. Ao entender isso, é possível relacionar as práticas as realidades políticas em que está inserida a investigação. É necessário que ao desconstruir o padrão social opressivo desconstruindo também a ciência como apolítica, a identidade de neutralidade que a ciência possui muitas vezes acaba por negligenciar a diversidade das experiências humanas (NAVAZ; KOLLER, 2006).

A psicologia deveria utilizar a construção performativa de gênero como pressuposto cientifico com uma atitude ética e política, questionando como são construídos sujeitos diante de discursos que marcam as vivências, corpos a partir de uma noção gerada. Compreender os comportamentos performativos que são colocados em prática através da produção de corpos e gêneros distintos entre o feminino e masculino. É através dessas construções que é produzido e expresso a subjetividade, e a realidade em que estar inseridos tem origem nessa construção (ANJOS; LIMA, 2016).

Para Zanello (2019), a psicologia é necessária questionar a participação da construção de gênero na formação de sintomas de sofrimento psíquico, como a condição de gênero permite a vulnerabilidade de determinados indivíduos para estressores e sofrimento deferentes entre homens e mulheres, este é um binarismo estratégico que gera e sustenta relações de poder. Para Prenh e Müning (2005) compreende que a necessidade de pensar as construções políticas e culturais da identidade e subjetividade são pontos fundamentais para a produção da ciência psicológica. 
Ao substituir o termo de papel sexuais pelo termo papéis de gênero nos estudos psicológicos, com o objetivo de se contrapor à concepção de essencialismo e naturalização dos papéis sexuais. 0 termo gênero veio para compreender que esses papéis não são naturais e sim construções históricas das relações sociais baseada na diferença entre os sexos como modo fundamental de do significado as relações de poder. Segundo Fávero e Maracci (2016), o homem era o senhor da razão e o modelo para a ciência, já as mulheres eram associadas à reprodução, à natureza, à essência materna e cuidadora, relacionadas a uma natureza inferior, sendo colocada em um lugar como o "outro" na relação dos sexos. Esses argumentos foram usados para justificar o modelo que colocava as mulheres em um lugar de exclusão social.

De acordo com Neves e Nogueira (2003), apesar das resistências a crítica feminista entrou na academia, com o objetivo de tentar compreender os efeitos da condição de gênero para a construção de conhecimento. A psicologia feminista crítica e se opõem a visão androcêntrica da psicologia tradicional, criando assim uma visão mais compreensiva e justa da mulher. Nas pesquisas e na clínica, nos anos 70 surgiu a psicologia feminista e a partir daí as terapias feminista emergiram com o foco em estudos e trabalhos com grupos de mulheres. A terapia feminista entende a opressão existente em uma sociedade com estruturas patriarcais não deve ser entendida como responsabilidade igual para todos, o poder que existe dentro das relações de gênero oprime alguns enquanto privilegia outros (NAVAZ; KOLLER, 2007).

A ciência, às vezes, parece estar a serviço da dominação e da domesticação social, quando o seu discurso é utilizado como instrumento de legitimação e de naturalização das desigualdades e das subordinações, quer sejam de gênero, de classe, de geração ou de etnia (NAVAZ; KOLLER, 2007, p. 10-11).

De acordo com Navaz e Koller (2006), foi através dos grupos de mulheres que relatam suas vivências surgem as primeiras terapeutas feministas com fundamentos psicanalistas e humanistas repensam as práticas terapêuticas tradicionais e assim formando um novo campo a psicologia feminista. A psicologia feminista é definida como um espaço estratégico entre o feminismo e a psicologia, construindo uma crítica à psicologia tradicional. Esses grupos de discursão de suas histórias e vivencias possibilitou uma conscientização coletiva das expectativas e padrões destinados aos papéis de gênero geravam discriminação, injustiças e desigualdades para as mulheres, e assim divulgando a ideia feminista que afirma que "o pessoal é político".

A psicologia feminista é elaborada por um processo de desconstrução e reconstrução das práticas terapêuticas, esse processo trouxe a psicologia a consciência de que esta foi omissa diante das relações de poder e problemas de gênero que fazem parte da construção social do indivíduo e que afeta este, em sua compreensão de si e dos outros (NEVES; NOGUEIRA, 2003).

As práticas terapeutas tradicionais estão presas à um idealismo apolítico, ligando o sofrimento psíquico as compreensões intrapsíquicas. As terapias feministas assumem um compromisso político e social, principalmente em relação as questões de gênero e papéis sociais atribuídos a homens e mulheres. As terapias feministas focam nos fatores contextuais como as desigualdades e a opressão patriarcal como origem para o sofrimento e dificuldade individual e familiar. A terapia feminista busca confrontar os papéis de gênero enquanto as terapias tradicionais tentam normatizar e acabam perpetuando essas relações de poder. As terapias feministas validam o saber individual e as experiências singulares de cada indivíduo (NAVAZ; KOLLER; 2007).

A terapia feminista tem como principal efeito a emancipação de mulheres, as terapias tradicionais presam pela preservação de um ideal livre de valores e pensamento político, recorrendo a elaborações intrapsíquicos como explicação para as psicopatologias o que acaba reforçando os papéis de poder tradicionais. Porem as terapias feminista ressaltam a necessidade de pensar e questionar os sistemas de valores e políticos, enxergando a psicopatologia como resultado das opressões sociais, ou seja, confortando os papéis e as normas de gênero e sexualidade (NEVES; NOGUEIRA, 2003).

Uma das terapias feministas é a terapia feminista da família que busca descontruir e denunciar o sistema que mantêm as mulheres em uma posição de inferioridade, subordinação e opressão, que existem em uma sociedade patriarcal. (NAVAZ; KOLLER 2006)

Para Neves e Nogueira (2009), há quatro princípios essenciais à prática feminista na psicologia. 0 primeiro é a necessidade de da atenção e analisar a diversidade de identidades pessoais e sociais das mulheres, assim também as expectativas e comportamentos que favorecem a opressão. 0 segundo está na proposta de aumento da consciência, abrindo as possibilidades para a cliente possa enxergar as estruturas sociais sexistas, de classe e raciais que tem influência sobre sua existência e qual essa influência. 
O terceiro é a criação de uma relação igualitária entre terapeuta e cliente, encorajando a cliente a propor seus próprios objetivos pessoais e a confiança nas suas experiências individuais e na sua capacidade de julgar e avaliar sua situação, o que reduz as diferenças de poder sociais. E por fim o quarto princípio que seria a valorização da mulher, uma autoavaliação das experiências, apoiando as clientes na identificação das suas potências e valorizações pessoais.

Para Navaz e Koller (2007), as terapias tradicionais definem-se como apolítica, compreendendo o sofrimento psíquico através dos construtos intrapsíquicos por outro lado a terapia feminista assume um compromisso político coma mudança, e estas focam nos fatores contextuais como as desigualdade e opressões sociais para compreender o sofrimento psíquico. As terapias tradicionais buscam um ajustamento e normatização dos papéis definidos e prescritos socialmente contribuindo para a perpetuação das relações de poder, as terapias feministas questionam esses papéis e as normas sociais valorizando a subjetividade, as experiências individuais e coletivas, dando espaço para a diversidade, buscando romper com as relações de poder.

As terapias feministas tem o objetivo de promover a mudança social, pois desafia o sistema de diagnóstico e tratamento usados pela psicologia tradicional. Os pressupostos do feminismo aplicados a psicologia transformaram a visão da psicologia, abrindo a para analisar e discutir as desigualdades entre os sexos como um problema de saúde pública. Quando são questionadas as assimetrias de poder entre mulheres e homens é revelado um problema grave de saúde, e a intervenção deve: "fazer frente, mobilizando as estruturas de toda uma rede social de apoio que possa efetivamente, mais do que suprir carências individuais, suplantar défices institucionais enraizados" (NEVES; NOGUEIRA, 2003).

Segundo Neves e Nogueira (2003), a despatologização da condição feminina presente na psicoterapia feminista pois esta substitui os fundamentos que justificam a psicopatologia pelos constructos intrapsíquicos que muitas vezes coloca as mulheres em um lugar de culpa e responsabilidade pelo seu sofrimento, com o foco além de reduzir os sintomas recorrentes em mulheres, a abordagem feminista busca tornar as mulheres mais conscientes de suas performances sociais, desenvolvendo autonomia em mulheres.

De acordo com Gomes (2011), ao usar gênero como instrumento analítico é básico usar a questão da diferença, lembrando que as categorias de gênero não possuem unicidade ou são fixas, há múltiplas possibilidades em ser mulher ou ser homem além da categoria de gênero como raça, classe, sexualidade e etnia. O foco nos estudos de gênero é a atuação feminina com toda a sua complexidade abrindo um caminho para novas reflexões e estudos de genro.

Para Neves e Nogueira (2003), a psicologia feminista é um instrumento de mudança e ativismo social e assumindo a função fundamental de empoderamento das mulheres, desconstruindo as desigualdades de poder tanto nos contextos terapêuticos quanto nos mais amplos como os sociais, enfraquecendo uma ideia estereotipada do adoecimento mental, despatologizando a condição feminina, construindo novos modelos de avaliação e intervenção não discriminatórios e assim construindo uma realidade terapêutica e social em que a justiça, a igualdade e a liberdade façam parte das ciências e experiências de cada indivíduo.

As psicólogas feministas fazem a desconstrução e reconstrução de práticas e metodologias dominantes. A metodologia feminista oferece a criação de uma prática terapêutica alternativa para a psicologia, principalmente uma terapêutica dirigida a mulheres. Os objetivos feministas sempre foram a mudança social para as relações de poder, e essa mudança social acontece quando os grupos oprimidos seja por gênero, raça, sexualidade, etnia, classe e outros marcadores sociais, adquirem poder para legitima suas construções de realidade e nelas ser capaz de construir transformações (NEVES; NOGUEIRA, 2003).

Segundo Gomes (2011), ao desconstruir esses alicerces intelectuais e culturais que suprimiam as pesquisas sobre gênero e principalmente sobre o gênero feminino, proporciona o surgimento da história das mulheres, esse surgimento é efeito do movimento e políticas feministas que traz à tona as mulheres na ciência.

Anjos e Lima (2016) consideram a produção de conhecimento é uma luta política, reconhecer o contexto histórico, político e não essencialista é uma tarefa que deve ser compreendida na psicologia. Ir contra a esse padrão binário de gênero é lutar contra as desigualdade e violências que esse padrão gera, perceber que a psicologia não é neutra porquê as vivências não são neutras. E quando não se faz críticas a essas permitimos que pessoas sejam excluídas e discriminadas por serem minimamente contra as normas sociais a que é aprisionada a sua existência. 
Este trabalho é uma pesquisa bibliográfica, qualitativa sistemática, que busca compreender ser gerado e as consequências dessa condição na saúde mental em mulheres, e a entrada da psicologia no estudo de gênero.

A pesquisa bibliográfica é construída a partir da leitura do material como livros e artigos científicos, esse é processo fundamental em vários tipos de pesquisa, mas a pesquisa bibliográfica é desenvolvida exclusivamente com fontes bibliográficas. A vantagem da pesquisa bibliográfica está no fato de esta permitir ao pesquisador uma ampla cobertura do fenômeno e estas são indispensáveis em estudos históricos (GIL, 2008).

Para Flick (2009) a pesquisa qualitativa é muito relevante para os estudos das relações sociais devido à pluralização das esferas de vida. E essa diversificação das esferas de vida se deve a acelerada mudança social. ainda completa que os aspectos essenciais da pesquisa qualitativa consistem a escolha de métodos e teorias adequadas, variedade de abordagens, reconhecimento e análise de diferentes perspectivas e na reflexão do pesquisador a respeito de sua pesquisa. Na pesquisa qualitativa as competências comunicativas constituem o principal instrumento para a coleta de dados e de reconhecimento. $\mathrm{Na}$ pesquisa qualitativa se considera a existência de uma relação dinâmica entre o mundo e o indivíduo.

Os estudos de gênero proporcionam para os avanços fundamentais das metodologias das pesquisas qualitativas, pois esses estudos examinam os processos de construção e de diferenciação de gênero se suas desigualdades (FLICK, 2009).

Os critérios de inclusão foram as seguintes variáveis: artigos em português, textos completos com acesso eletrônico. Foram utilizadas publicações a partir de 1999, tendo em vista a dificuldade em achar referencias dos últimos cinco anos que tratassem do assunto.

A coleta de dados consistiu no acesso as ferramentas digitais de bases de dados SciELO (Scientific Electronic Library Online) e livros. Foram considerados os termos de busca: sofrimento psíquico em mulheres, saúde mental feminina, feminismo e psicologia, psicologia feminista, a condição de gênero, desigualdades de gênero e o papel da psicologia nos estudos de gênero.

Através da leitura de 28 fontes entre eles livros, artigos científicos e trabalhos acadêmicos, em português que atendem aos critérios e objetivos delimitados para esta pesquisa de construção e elaboração do pensamento cientifico sobre a condição de gênero e seus efeitos na saúde mental feminina assim como uma alternativa para a psicologia compreender e pensar nessa condição e atuando de forma ética.

Na organização do material para a elaboração da pesquisa, ocorreu em etapas de procedimentos do Trabalho de Conclusão de Curso onde foi realizado a identificação de bibliografias, análise e interpretação do material, revisão e relatório final. Na primeira etapa as literaturas selecionadas passaram por uma leitura em que foram analisadas e as que não conseguirem contribuir como objetivo do estudo foram descartadas. As selecionadas foram lidas de forma mais profundas e analítica com o objetivo de buscar respostas e a discursão dessas respostas.

Este trabalho é uma revisão e não foi submetido a avaliação do comitê de ética e pesquisa, porém respeita os aspectos éticos da pesquisa cientifica bibliografia respeitando a autoria de todos os autores como prescrito na lei 9.610/98, através do uso das normas da Associação Brasileira de Normas Técnicas (ABNT), para construir essa pesquisa.

\section{DISCUSSÃO TEÓRICA}

\section{A compreensão histórica e social da condição de gênero}

Ao analisar o contexto histórico da condição de gênero depara-se com a pergunta de como se conceitua gênero, o que é ser mulher e o que é ser homem foi possível obter o resultado de que o gênero é uma construção social do biológico, essa construção está presente desde o nascimento e acompanha até a morte, influenciando como se comportar, ser e sentir e esse padrão tem efeitos sobre a subjetivação, a forma como compreender os outros e a si mesmo.

Sobre o tema gênero, diversos teóricos estudaram essa condição e seus efeitos. Como Nogueira (1999) que define o feminino e masculino como construções ideológicas que os marcam como opostos através das características do corpo, fazendo das diferenças algo natural que determina o comportamento e pensamento individual afetando as relações sociais como valores e formas de ser sociais diferentes para homens e mulheres. Fávero e Maracci (2016) explicam que as diferenças sexuais biológicas constroem 
uma definição social para o corpo, um padrão de comportamento do sexo, o gênero representa o papel social do corpo sexuado e é o mediador das relações sociais.

A compreensão histórica da condição de gênero para Zanello e Silva (2012) tem sua origem nas relações sociais, onde é construído maneiras diferentes de ser a partir de diferenças do sexo. As autoras agregam que a construção de gênero acaba muitas vezes por reduzir a análise do sujeito aos padrões e estereótipos definidos a parti do corpo. Já para Anjos e Lima (2016) a definição de gênero surge como uma forma de desconstruir a ideia de que a biologia é o destino, compreendendo assim o gênero como uma interpretação cultural sobre o corpo sexuado, estes ainda completam afirmando que essa ideia é muito limitada por possuir apenas dois destinos deveriam existir diversas expressões assim como a diversidade cultural humana.

O conceito de gênero para Zanello, Fiuza e Costa (2015) vai além do determinismo biológico que está presente quando se usa o termo sexo e diferença sexual, no entanto a diferença sexual é um fator para a construção social de gênero, o fator biológico descoberto através das possibilidades culturais. Anjos e Lima (2016) descrevem gênero como dispositivo construído pelas relações de poder sociais, com o objetivo de condicionar o comportamento e emoções em um padrão de gênero e é nesse processo que o movimento feminista surge ao fazer críticas e questionamentos sobre a condição de gênero.

As autoras Fávero e Maracci (2016) expressam a construção dos papéis de gênero definidos para delimitar e caracterizar as funções, deveres e os valores sociais para cada sexo, definindo-os como gênero feminino e masculino. As autoras ainda completam que os papéis de gênero podem ser formas de compreender a cultura em que o indivíduo está inserido, pois como Santos et al (2016) denotam o gênero é um produto de representação social, com características psicológicas e comportamentais diferentes definidas para homens e mulheres.

Zanello, Fiuza e Costa (2015) explica o gênero como uma performance do sexo, esta acontece nas repetições de comportamentos e característica rígidas de gênero que vão se cristalizando criando a sensação de naturalização, essa performance é realizada como se essas características fossem naturais e estas não são naturais. Como Rohden et al (2009) explicam o comportamento binário ou masculino e feminino é padrão aprendido, um papel de gênero imposto socialmente, a cultura que ensina a performar gênero, desde o nascimento, e existe uma pressão e expectativa social de como deve se expressar gênero, e qualquer mesmo que mínima fuga dessa expectativa é extremamente criticada e inferiorizada.

Por uma outra perspectiva com uma pesquisa voltada para a biologia humana e a condição social influenciada pelo corpo biológico, Senkevics e Polidoro (2012) estão de acordo com as outras definições explicadas anteriormente e explica o gênero como organização social e através desta é realizada as definições de que se é na sociedade, o papel e posição social a ser desenvolvida por um determinante biológico, o sexo biológico não determina o ser homem ou ser mulher, esse ser não é natural ou biológico e sim cultural, definida pela cultura em que está inserido, aprendidos e desenvolvidos socialmente. A biologia não determina os comportamentos relacionados aos sexos. Zanello, Fiuza e Costa (2015) concluem que a repetição e performance de gênero é uma estratégia de sobrevivência porque quando este padrão não é seguido os que não seguem são punidos.

Pinheiro (2012) descreve que para compreender a condição de gênero é fundamental rejeitar o determinismo biológico que define o que é ser mulher e o que é ser homem. Butler (2018) explica que o torna-se mulher ou homem em uma sociedade binária é obrigar o corpo a conformar e performar com uma ideia histórica de mulher e homem. A autora acrescenta que não há na sociedade alguém que não sofra a marca do gênero desde seu nascimento, não há ninguém que não seja gendrado. Para autora desde que o nascimento todos são marcados pelo sexo biológico, ou seja, é pela genitália que será definido as características, gostos, comportamentos, emoções e condição social de um indivíduo. Pinheiro (2012) finaliza com a afirmação de que para compreender a condição de gênero é necessário saber a diferença entre sexo e gênero.

A diferença entre sexo e gênero segundo Santos et al (2016) está na análise de corpos sexuados e os gêneros construídos pela cultura a construção de um sistema binário de gênero em uma relação entre gênero e sexo. Ao entender que o sexo não se reduz a uma essência anatômica natural e sim a dualidade dos sexos estabelecidas através do contexto histórico e cultural. Essas construções binárias se reproduzem pelo discurso da ciência com interesses políticos e sociais da cultura que media o padrão de gênero. Para definir gênero Butler (2018) utiliza o termo performance e não reconhece a definição de que gênero como um conjunto de elementos essenciais e naturais, mas também não apenas como características culturalmente impostas. A divisão binária de gênero é performativa só existindo no momento em que é 
expressa, gênero não é uma essência de um determinado corpo e sim constituído pelas repetições da performance feminina ou masculina que é repetida a todo momento.

Butler (2018) define a estrutura binária a que todos são submetidos, e que constroem padrões definindo a vivência de gênero, dentro dessa construção é formulada também uma relação de poder entre os gêneros, a construção de gênero citada pela autora não se refere apenas a uma definição a partir da diferença corporal, a construção de gênero se dá também nas possibilidades culturais. A compreensão de gênero de Zanello, Fiuza e Costa (2015) é construída através da análise dos papéis e padrões de ser homem e ser mulher que fazem parte do funcionamento social. A experiência de gênero é definida pela cultura em que o indivíduo está inserido. A condição de gênero é fundamental para compreender fatores para o sofrimento psíquico. Em conclusão Beauvoir (2016) descreve que não existem fundamento biológico e psicológico que defina o ser mulher, essa definição é criada socialmente. Expressado bem em sua frase "ninguém nasce mulher, torna-se mulher."

O gênero para Zanello e Silva (2012) surge como uma categoria que descreve as interações sociais, se opondo a definição anterior que limitava gênero ao determinismo biológico ao mudar esses termos tornase possível abrir a visão para gênero e sua condição e particularidades, e perceber os diversos sofrimentos existentes nas vivências de gênero. Os papéis e valores atribuídos aos gêneros são antes de tudo relações de poder. Na sociedade seja ocidental ou oriental, a cultura é marcada pelo sistema patriarcal, onde a mulher é historicamente colocada à margem da sociedade.

Rohden et al (2009) concluem que o padrão de gênero é composto por uma hierarquia que define quem e o que é inferior ou superior. E a figura feminina sempre ocupa um lugar inferior nessa relação de poder, as mulheres e até homens com comportamentos definidos como femininos são depreciados. Para Zanello e Silva (2012) as relações de gênero são relações de poder, a sociedade é marcada pelo sistema patriarcal onde a mulher histórica é colocada à margem da sociedade, os papéis de gêneros definidos a mulheres é inferior aos dos homens.

Zanello e Silva (2012) contribuem ainda que refletir sobre gênero é desnaturalizar as diferenças que existe e são dadas como certas, romper com a definição apenas biológica, levando a reificação do tema. Ao analisar a condição de gênero observa-se como afeta a vivência das experiências individuais e como influência no desenvolvimento de sofrimento psíquico pois a construção social e cultural de gênero define diferenças e valores sobre os sexos, marcando um superior e um inferior, criando assim uma relação de poder que pode possuir diversos marcadores sociais o gênero é um deles. A definição atual de gênero foi concebida pela teoria feminista e abre a ciência para as possibilidades para a desconstrução das relações de poder e a exclusão que estas relações causam. De acordo com Santos et al (2016) a desconstrução dos estereótipos presentes nas experiências femininas, estas experiências recebem influência de fatores como raça, classe e sexualidade além de gênero.

Para Zanello (2019) o gênero é formado por características produzidas através de comportamentos e emoções definidas a partir do corpo sexuado. Para exemplificar essas características a autora explica os dispositivos de gênero que formam os padrão de comportamento e subjetivação esperadas pelo sexo, os dispositivos da eficácia que é o masculino com o foco na virilidade sexual e laborativa, esse dispositivo constrói o comportamento que Zanello, Fiuza e Costa (2015) definem como "comedor" o homem ativo, forte e másculo. E para as mulheres a autora Zanello (2019) afirma que foi definido os dispositivos amoroso e de maternidade que é bem explicado pela autora Swain (2006) ao afirmar que o amor é para a mulher o que o sexo é para o homem é sua razão de viver. Sendo assim a mulher deve amar e ser amada do contrário não é uma mulher. Os dispositivos de gêneros inventam e definem quem o corpo vai ser, através das diferenças biológicas classifica homens e mulheres de formas diferentes na sociedade.

\section{Fatores da condição de gênero que influenciam a saúde mental feminina}

O gênero é uma marca que atravessa diversas esferas da vida humana, e a saúde mental não é diferente, afetando homens e mulheres, porém quando observa-se a condição de gênero das mulheres percebe-se uma realidade de desigualdades, opressão e inferioridade em que as mulheres ocupam o lugar abaixo dos homens, em que uma das principais consequências dessa hierarquia é a violência de gênero, a violência contra a mulher é um exemplo da realidade cruel das mulheres. A posição social em que se encontra a mulher e de extrema vulnerabilidade para o sofrimento psíquico com um papel social construído para servir os outros, sempre vista na perspectiva de homens. Alguns autores concluem que existem relações entre a condição feminina e a origem de sofrimento psíquico como Santos et al (2016) concordam afirmando que a marca de gênero afeta todos criando uma hierarquia de gênero em que a mulher está em 
uma posição inferior ao homem, essa inferioridade destinada as mulheres gera diversas opressões, com um sistema de poder que transforma a biologia em verdade absoluta e nessa verdade a mulher é o outro.

Para Zanello e Silva (2012) existem diversas categorias que marcam a vivência do sujeito, a classe, a raça, a sexualidade e o gênero fazem parte dessas marcas. A marca do gênero feminino é a submissão, a entrega de si em favor do outro, a busca da aparência perfeita e o cuidado com os outros para os outros, a sociedade constrói um papel social de invisibilidade para as mulheres. As autoras ainda afirmam que para às mulheres é destinado o papel de renúncia, abrir mão de si mesma em cuidar do outro, e cuidar do corpo sempre buscando um ideal estético. Santos et al (2016) concorda e declara que a opressão sofrida pelas mulheres e gerada pelo sistema de poder que transforma o sexo biológico em produtos da atividade humana, colocando as mulheres em um lugar inferior e essa noção é naturalizada na sociedade.

A experiência de ser homem e ser mulher é definido pelos valores culturais gerados na cultura e fazem parte das interpretação dos outros indivíduos e de si mesma, a vivência de gênero tem influência na esfera da saúde mental, as desigualdades originadas dessas relações de poder podem gerar sofrimento psíquico especialmente nas mulheres que tem a marca da inferioridade. Zanello, Fiuza e Costa (2015) completam ainda que a vivência de gênero parece ser algo extremamente individual, mas as experiências de malestares subjetivos são moldadas por uma configuração social.

Este é também o posicionamento de Santos (2009) que afirma que o sofrimento psíquico pode parece algo individual, mas na verdade é uma condição coletiva, construída socialmente com valores e normas sociais e o gênero está nessa construção configurando o sofrimento a partir da experiência de gênero com padrões binários. Alves (2017) concorda que a marca do gênero feminino uma marca de opressão, a experiência de ser mulher é uma realidade de submissão e desigualdades, essas desigualdades estão fixas nas estruturas da sociedade patriarcal. E somente quando gênero é problematizado é possível observar essa realidade e compreender que o sofrimento psíquico em mulheres na maioria das vezes tem origem em condições coletivas e públicas e não privadas. 0 ser e suas vivências sociais da experiência de ser mulher tem uma marca que atravessa sua saúde mental, com condições completamente desiguais e opressivas.

O sofrimento psíquico é uma experiência constituída socialmente e são moldados segundo os valores e normas de gênero, com desigualdades entre homens e mulheres que geram sofrimento psíquico. Zanello, Fiuza e Costa (2015) as experiências de sofrimento psíquico são relações também sociais, quanto mais baixa a posição social e as desigualdades sociais mais aparecem os sintomas. Ao estudar gênero é essencial compreender como a cultura em que o indivíduo está inserido, sustenta a hierarquia que vulnerabiliza determinado grupo que pode gerar sintomas de sofrimento nesses. Para perpetuar essa hierarquia Zanello (2019) aponta que é criado um processo dos afetos e das emoções, performances comportamentais de gênero que atravessa a vivência indivíduo.

Zanello, Fiuza e Costa (2015) mostram que o sofrimento psíquico em mulheres é marcado por falas relacionadas a problemas em relacionamentos, frustações em casamento, maternidade, acreditar não ser amada, falta de satisfação com as tarefas domésticas, baixa autoestima devido a aparência distante do padrão e fragilidade emocional. Assim como outros marcadores além do gênero aparecem como fator para o sofrimento como raça, idade, classe, sexualidade, baixo nível de escolaridade e a submissão às situações de violência. Os transtornos mentais tem fortes características de gênero. Ao falar do sofrimento das marcas de gênero Alves (2017) conclui que é necessário que os profissionais de saúde mental compreendam gênero que muitos ainda estão presos ainda no determinismo biológico do sexo não ampliando sua visão para o fator gênero, o autor coloca que é indispensável ter uma lente de gênero para identificar as questões de gênero no sofrimento e adoecimento mental.

Para Zanello, Fiuza e Costa (2015) a construção dos papéis de gênero geram estereótipos que estão fortemente enraizados na cultura, esses estereótipos criam e perpetuam as desigualdades criadas pelas relações de poder e hierarquias de gênero, os valores culturais que formam essas relações são os padrões emocionais e comportamentais que é chamado de performance de gênero que define o que é ser homem e o que é ser mulher.

Esses estereótipos formam estigmas que é definido por Goffman (2008) como uma referência a uma característica muito depreciativa, algo que o separa dos demais indivíduos classificando os mesmo em bons ou maus. 0 termo estigma, portanto, será usado em referência a um atributo profundamente depreciativo, mas o que é preciso, na realidade, é uma linguagem de relações e não de atributos. Um atributo que estigmatiza alguém pode confirmar a normalidade de outrem, portanto ele não é, em si mesmo, nem horroroso nem desonroso. 0 estigma social das marcações do gênero são fatores 
significativos para o sofrimento psíquico as mulheres sofrem com a marca de gênero que as colocam em uma situação inferior e de vulnerabilidade.

Zanello (2019) conclui que os comportamentos ditos masculino e feminino em que há um padrão distinto de ser, essa forma binária e essencialista coloca o homem em uma posição de superioridade devido a sua força, lógica e masculinidade. Já as mulheres são colocadas em um lugar de inferioridade por ser considerada frágil, emotiva, dócil e cuidadora. Esses padrões de comportamento devem ser seguidos e são ensinados desde o nascimento a experiência de gênero é destinada desde que os olhos se abrem, fechando assim as possibilidades de escolhas e experiências, o distanciamento deste padrão mesmo que mínimo é fortemente reprimindo socialmente, gerando discriminação e violência.

Essa construção social da origem as relações de poder e faz do gênero um marcador da desigualdade social, gerando diversos problemas sociais e um deles é a inferioridade da mulher em relação ao homem que coloca está em uma posição de vulnerabilidade. Dentro desse diálogo a autora Santos (2009) afirma que os múltiplos papéis que as mulheres desempenham são significativos para as incidências de transtornos mentais e comportamentais, as mulheres são sufocadas pelos papéis de mãe, esposa, cuidadoras e educadoras, com sua função social totalmente relacionada a cuidar dos outros em que até as profissões vem com o rótulo de gênero. As mulheres também tem sua sexualidade reprimida e todas as suas escolhas relacionadas ao amor e a ser amada.

Através de estudos de Zanello, Fiuza e Costa (2015) apontam que os valores e os ideias de homem e mulher que estão inseridos em na cultura. Nas mulheres as categorias valorizadas possuem três eixos: renuncia sexual, beleza estética e características de comportamento e emoções definidas como femininas. A imagem que é sempre relacionada culturalmente as mulheres é a beleza, com um padrão de beleza inacessível para a maioria das mulheres e quando elas não alcançam esse padrão são consideradas menos mulher.

Swain (2006) define as características definidas de cada gênero como fruto dos dispositivos de gênero, o masculino chamado de dispositivo da eficácia relaciona o homem ao mundo do sexo e do trabalho para o homem ser "homem de verdade" é necessário que ele seja eficaz e tenha sucesso nessas áreas. E para as mulheres os dispositivos que as definem são o dispositivo amoroso e o materno mais voltados para o cuidado e o amor, a mulher deve amar e ser amada para ser "mulher de verdade", deve cuidar de sua aparência para isso ser sempre bonita e cuidar de todos e tudo, filhos, marido, casa e sua aparência.

Nesse contexto, entende-se que os homens também possuem um papel social de gênero com opressões em que tem que mostrar virilidade e masculinidade sem sair em nenhum momento da performance de gênero. Com esse pensamento Tiburi (2018) contribui com afirmando que o patriarcado oprime a todos, mulheres e homens porem de nível e formas diferentes. Porem nas relações patriarcais de gênero que exerce o lugar de poder é o homem e esse e autor das desigualdades e violências contra as mulheres.

A autora Fernandes (2009) declara que ao considerar que o corpo é o todo que é o que define os valores, característica e expectativas de uma mulher é violenta pois é nessa ordem que se constroem as relações de poder definindo a inferioridade ou superioridade de gênero e dando origem as diversas formas de violência.

Zanello, Fiuza e Costa (2015) concluem que a condição de gênero afeta a saúde mental, em especial para as mulheres em que a condição de gênero condena-la a uma existência marcada por desigualdades em que para que uma mulher seja considerada mulher é necessário que esta seja doce, carinhosa, recatada, amorosa e devotada. Para ser mulher as mulheres tem que se prender ao desejo do outro, uma vida presa no silencio, na impotência e invisibilidade.

Concordando Cruz (2009) afirma que as relações de gênero como um fator significativo para o sofrimento psíquico e ainda adiciona a depressão como exemplo de adoecimento de gênero em que as mulheres são associadas a depressão com os critérios diagnósticos próximos dos estereótipos femininos e distante dos masculinos formando assim uma associação. A autora ainda afirma que os estudos de gênero são fundamentais para a compreensão do sofrimento psíquico a condição de gênero é muito influente em como cada indivíduo vai sentir e a realidade que o rodeia fazendo desse um fator significativo para o surgimento do sofrimento.

Concordando com Cruz (2009), Zanello (2019) afirma que com a prevalência feminina em adoecimentos como a depressão, é necessário evitar crenças de naturalização do binarismo de gênero, existem muitos fatores que contribui para essa incidência de adoecimentos mentais em mulheres umas dessas explicações 
é a biológica que relaciona os hormônios femininos como causa para os sintomas, outro é a condição social do gênero feminino que é marcada por desigualdades e violências. Mas a autora ainda da outra explicação para essa predominância em mulheres o fato de os critérios diagnósticos em especial o da depressão apresenta sintomas muito distantes das características definidas como masculinas e próximas das femininas.

A construção social e cultural feminina descrita por Beauvoir (2016) caracteriza as mulheres através de características com a doçura, submissão, pudor, passividade, contenção e silencio, condenando-a a uma vida de invisibilidade e objetificação. Para que o termo gênero possua liberdade de interpretação seria necessário que o termo mulher e feminino e o termo homem e masculino fossem além do corpo, assim aplicados a qualquer corpo independente do sexo biológico designado.

Porém a realidade não possui essa pluralidade as classificações de gênero estão presas à uma concepção binaria do sexo. De acordo com Anjos e Lima (2016), apenas ao estudar e questionar as relações de gênero é que se torna possível abrir o caminho para as possibilidades de enxergar as mulheres como seres sociais e assim descontruir as hierarquias que colocam essas em uma situação de vulnerabilidade.

\section{O papel da psicologia diante das relações de gênero e a psicologia feminista}

Diante de todos os tópicos anteriores percebe-se a necessidade de compreender a condição de gênero na ciência em especial uma ciência como a psicologia que busca compreender o ser humano em todos os seus aspectos sociais, biológico, psicológico e histórico. Somente através dessa compreensão é possível perceber as reais condições de cada indivíduo e destruir as relações que criam e perpetuam as desigualdades gerando sofrimento psíquico. E foi assim que o feminismo entrou na psicologia através dos objetivos do movimento político e social das mulheres que formaram objetivos científicos que atendessem as suas necessidades construindo assim a Psicologia Feminista.

As autoras Santos et al (2016) afirmam que a psicologia diante das relações de gênero tem o papel de compreender e analisar as condições e consequências desses. Os estudos de gênero e feministas estão se desenvolvendo em diversas áreas das ciências humanas e sociais no Brasil, assim consolidando um campo amplo para pesquisas. As autoras acrescentam que no brasil o termo gênero foi tomado pelos estudos acadêmicos como categoria para a análise crítica das desigualdades que marcam a experiência e vivência das mulheres em relação aos homens.

Pinheiro (2012) afirma que para introduzir o papel da psicologia nos estudos de gênero é de compreender a origem do termo gênero. 0 conceito gênero como já explicado antes foi cunhado pelo feminismo com 0 objetivo de questionar o papel das mulheres na sociedade. 0 feminismo surge através da busca por uma luta que atenda às suas necessidades as mulheres montam grupos e reivindicam seus direitos e a partir dessa luta o movimento feminista percebe que também é necessário ocupar a ciência que antes era ocupada apenas por homens com estudos para homens. Diante dessa situação as mulheres ocuparam a ciência com o objetivo de compreender a si mesmas e a condição a qual são destinadas por ser mulher.

Gomes (2011) concorda e acrescenta que os estudos sobre as mulheres ainda não são bem aceitos pela ciência com a afirmação de que fogem da imparcialidade que é muito desejada pela ciência, e coube as mulheres estudar seu próprio sexo e condição. As autoras Navaz e Koller (2007) concluem que muitas vezes a ciência está a serviço da dominação social através do uso das discussões que fundamentam a naturalização da desigualdade. Fávero e Maracci concorda e acrescenta que por muito tempo o homem era o dono da razão e o modelo da ciência com representante da raça humana e a mulher estavam condenadas a ser o outro, aquele que não é perfeito.

Garcia (2011) afirma que gênero é um tema que está em crescimento na ciência, porem a entrada desse tema nos estudos ainda assustam e gera incomodo em muitas áreas. Assim como as mulheres são consideradas o diferente o outro e são inferiorizadas por isso, com suas lutas o feminismo não é diferente sempre consideradas como antinaturais. Por esse motivo quando o tema gênero vem surge muitas vezes é esquecido o feminismo que é um movimento fundamental para a construção dos estudos de gênero.

Nogueira (1999) ainda completa que gênero e feminismo é um tema muito descredibilizado na comunidade cientifica e isso não é diferente com a psicologia, com a afirmação de que esses temas retiram a neutralidade pois ao advogar a favor de um determinado grupo essa não seria mais imparcial, e a ciência acaba muitas vezes por inviabilizar vivencias diferentes do padrão.

Santos et al (2016) afirmam que aqui no Brasil os estudos de gênero e feministas estão em destaque nas ciências humanas e sociais e se tornando um campo amplo e solido para pesquisa. As pesquisas e 
produções feministas tem uma característica crítica e um objetivo emancipatório buscando libertar as mulheres das opressões presentes na sociedade patriarcal. Para Zanello (2019) os estudos de gênero ainda é algo novo na ciência, não há muitos teóricos de gênero e a maioria compartilham as mesmas opiniões e objetivos, concordando que a saúde mental tem efeito sobre a saúde mental principalmente as mulheres que estão mais vulneráveis, que é papel da ciência desconstruir as desigualdades presentes nas relações de gênero e como os estudos de genro são um campo rico para pesquisa.

A autora Santos (2009) determina que para estudar saúde mental e gênero é necessário considerar os fatos sociais que engendram os transtornos mentais fazendo com que a experiência de sofrimento psíquico seja diferente para homens e mulheres. A autora ainda completa afirmando que é fundamental compreender a masculinidade e feminilidade como relação de poder em que um é superior ao outro para assim entender as desigualdades de gênero.

Para a psicologia de acordo com Prehn e Hüning (2005) é necessário pensar as construções políticas e culturais da subjetividade pois a subjetividade é um dos pontos principais da psicologia, compreender o indivíduo além de seus sintomas e queixas, buscando entender o que no contexto social e cultural tem efeito sobre sua individualidade e sua construção social.

É comum que a ciência ao se fecha para as subjetividades acabem por reproduzir estereótipos de gênero e assim perpetuando as desigualdades. Senkevics e Polidoro (2012) concluem que ao entrar na ciência o movimento feminista reivindica uma postura cientista que atenda e busque entender as condições de gênero para assim desconstruir as desigualdades e construir uma realidade mais igualitária para as mulheres, e segundo os autores é esse o principal papel da ciência. A autora Zanello (2018) concorda e completa afirmando que psicologia feminista fornece as mulheres as possibilidades para enfrentar o padrão social questionando seus papéis e as desigualdades que lhe oprimem.

Nogueira (1999) afirma que os estudos com objetivos feministas na psicologia são diferentes dos estudos tradicionais, por questionarem todos os pensamentos anteriores sobre gênero buscando desconstruir a condição de gênero em que estão presentes, realizando uma crítica social e política, propondo uma mudança da realidade desigual gerada pelas relações de gênero.

As feministas na ciência proporcionaram uma visão mais ampla e inclusivas das condições sociais de gênero, ao reconhecer as desigualdades entre homens e mulheres e como é fundamental considerar a condição de gênero nas pesquisas e prática profissional. Zanello, Fiuza e Costa (2015) descreve que o movimento feminista trouxe a desconstrução do pensamento fixo de gênero para a ciência, trouxe a definição de instabilidade que não segue um padrão rígido de comportamento e emoções.

De acordo com Garcia (2011), a sociedade ocidental possui uma ordem em que o diferente é inferior e nessas sociedades com uma cultura patriarcal o diferente por tanto inferior é a mulher, em lugar de opressão diferente dos homens. Como o objetivo de mudar essa realidade se construiu a luta feminista a autora acrescenta ainda que a ciência tem um importante papel social como agente da mudança, com essa característica o movimento feminista entra na ciência com o objetivo de compreender quem é a mulher e questionar seu lugar na sociedade e as desigualdades desse lugar mas a entrada do feminismo na ciência não foi bem aceita e é descredibilizada pela afirmação de que essa entrada descredibiliza a neutralidade cientifica assumindo assim um lado.

Nogueira (1999) descreve que ao estudar as consequências de ser mulher em uma sociedade patriarcal percebe-se que a ciência feminista é necessária, esse olhar crítico e político é fundamental para construir uma ciência justa que atenda às necessidades sociais. Quando a ciência evidencia as relações de poder essas também compreendem os demais marcadores sociais como raça, sexualidade, classe, etnia e condição além do gênero. Segundo Gomes (2011) esses alicerces intelectuais e culturais que suprimiam as pesquisas sobre gênero e principalmente sobre o gênero feminino são desconstruídos e possibilitam que as mulheres possam contar e entender sua história, e isso só é possível através da entra do movimento e politicas feministas que traz à tona as mulheres na ciência.

Para Zanello (2019) compreender o processo de engendramento na subjetivação é fundamental compreender a cultura e época em que o sujeito está inserido, pois é no âmbito social que o engendramento acontece formando relações de poder. Para Gomes (2011) ao estudar gênero é preenchido um vazio, passando a da voz à experiências antes silenciadas como a feminina que em seu contexto histórico e social são invisíveis e diferentes. A autora considera necessário analisar as relações de gênero compreendendo que o masculino e feminino se constrói na de forma sociocultural e histórica. Usando o gênero como um instrumento de análise para compreender as diferenças e desigualdades sociais e seus efeitos na saúde mental. 
Santos (2009) concorda e conclui que ao estudar gênero observa-se a realidade da construção e expressão de gênero que estão inseridas na cultura e constrói a subjetividade assim como o sofrimento psíquico.

A autora Nogueira (1999) conclui que o feminismo a psicologia passou a reconhecer o sexismo e incluir essa realidade em pesquisa, estudos e na atuação psicológica. Com essa nova perspectiva a psicologia agora feminista entende e analisa os problemas de gênero. 0 feminismo traz um novo conceito e visão para a psicologia. A psicologia diante do tema gênero possui três períodos para compreender o ser mulher ou homem e as relações de poder e gênero esses períodos surgem junto com as 3 ondas do feminismo.

Para Saavedra e Nogueira (2006), o primeiro período inicia com ausência feminina como pesquisadoras e como indivíduos na pesquisa, o segundo as mulheres entram na ciência como pesquisadoras passando a olhar para si próprias como sujeito da pesquisa; e no terceiro período que é o atual fica marcado como o período em que as teorias feministas entraram e fazem parte dos estudos, pesquisas e práticas psicológicas, com o foco de desconstruir as estruturas arcaicas e opressoras que faziam parte da ciência e assim da voz as mulheres.

Quanto a Neves e Nogueira (2003) afirmam que como profissionais de psicologia é fundamental utilizar a ciência e profissão com o objetivo de buscar a emancipação feminina, lutando contra o patriarcado e as opressões impostas por esse sistema. Isso significa escolher a não neutralidade da psicologia, politizando as práticas e espaços terapêuticos. As autoras acrescentam ainda que a psicologia feminista é uma crítica e através dela surge uma visão justa e igualitária para as mulheres.

Navaz e Koller (2007) afirmam que a entrada do feminismo na ciência foi muito criticada, mas mesmo assim permaneceu firme e conquistou seu espaço e nos anos 70 surge a psicologia feminista que dão origem as terapias feministas com o foco em grupos de mulheres. Como princípio fundamental a psicologia feminista conclui que a responsabilidade não igual para as relações de poder, o poder que há nas relações de gênero oprime alguns e privilegia outros.

Prenh e Müning (2005) delimitam que a psicologia feminista não é uma abordagem psicológica, mas sim uma prática psicológica politizada e critica de uma sociedade desigual que oprime e excluem as mulheres. Essa prática compreende o ser humano sem uma verdade absoluta sobre esse, e sim analisando esse ser com sua construção social, política, histórica, cultural e subjetiva, entendendo que estas não estão separadas e que são diversas. A psicologia feminista faz uma desconstrução dos padrões de comportamento ditos femininos e masculinos que limitam as experiências individuais e oprime os indivíduos a uma relação de poder em que o gênero é mais uma marca da desigualdade, deixando principalmente as mulheres em situação de vulnerabilidade.

Navaz e Koller (2006) classificam a psicologia feminista como uma estratégia entre o feminismo e a psicologia que constrói uma crítica a psicologia tradicional. 0 início da psicologia feminista ocorre quando nos Estados Unidos grupos de mulheres se unem para dividir suas experiências e assim por compreender a si aos outros pela perspectiva de gênero. E é aqui que surgem as primeiras terapeutas feministas que iram repensar as práticas terapêuticas tradicionais e constroem uma nova visão a Psicologia feminista.

Prenh e Müning (2005) afirmam que a chegada do feminismo na psicologia deixou claro que não é possível estudar o ser humano de uma forma neutra e imparcial, a psicologia se desprende da neutralidade assumindo uma abordagem ativa com o foco de incluir a todos de forma completa. Diante disso as autoras Zanello, Fiuza e Costa (2015) discorrem que feminismo na psicologia repensa o ser mulher além dos limites dos padrões de gênero podendo compreender o ser homem ou ser mulher como condição social construía e perpetuada pela cultura.

Para Zanello (2019) é necessário também questionar a contribuição da construção de gênero na formação de sintoma de sofrimento psíquico pois a condição de gênero permite a vulnerabilidade em especial para as mulheres criando assim sofrimento distintos para homens e mulheres. Prenh e Müning (2005) compreende a necessidade de pensar as construções políticas e culturais da identidade e subjetividade pontos fundamentais para a produção da ciência psicológica.

Neves e Nogueira (2003) discorrem que as terapias tradicionais permanecem fixas em um ideal apolítico, sempre relacionando o sofrimento psíquico e adoecimento mental apenas a compreensões intrapsíquicas diferente das propostas das terapias feministas é a formação de um compromisso político e social, focando em fatores sociais como as desigualdades e as opressões de gênero, confronta os papéis de gênero enquanto as terapias tradicionais muitas vezes acabam por perpetuar e normalizar o que dá forças as relações de poder. 
Gomes (2011) afirma que ao analisar gênero observa-se que é necessário compreender que o feminino e masculino são formados a partir das relações e interações constituídas em um tempo e espaço, a construção de gênero é sociocultural e histórica. Afirmando que ao usar gênero como instrumento analítico preciso usar a questão da diferença, lembrando que as categorias de gênero não possuem unicidade ou são fixas, há múltiplas possibilidades em ser mulher ou ser homem além da categoria de gênero como raça, classe, sexualidade e etnia. 0 foco nos estudos de gênero é a atuação feminina com toda a sua complexidade abrindo um caminho para novas reflexões e estudos de gênero.

Para as autoras Navaz e Koller (2007) as terapias tradicionais definem-se como apolítica, compreendendo o sofrimento psíquico através dos construtos intrapsíquicos por outro lado a terapia feminista assume um compromisso político coma mudança, e estas focam nos fatores contextuais como as desigualdade e opressões sociais para compreender o sofrimento psíquico. As terapias tradicionais buscam um ajustamento e normatização dos papéis definidos e prescritos socialmente contribuindo para a perpetuação das relações de poder, as terapias feministas questionam esses papéis e as normas sociais valorizando a subjetividade, as experiências individuais e coletivas, dando espaço para a diversidade, buscando romper com as relações de poder.

Para concluir, Anjos e Lima (2016) alegam que a produção de conhecimento é uma luta política, reconhecer o contexto histórico e político de um indivíduo é uma tarefa que deve ser aprendida pela psicologia. A psicologia deve ir contra o padrão binário de gênero que geram desigualdades e violências, construindo assim uma psicologia política e não neutra, já que as realidades não são neutras, não se pode permanecer fixo em um padrão que já não representa a realidade.

Garcia (2011) declara que a ciência faz parte da política, a ciência é um campo significativo para os movimentos sociais, quando questões sociais como desigualdades e violências entram na perspectiva da ciência está assumem um papel social importante em defesa da igualdade, liberdade e direitos humanos. A ciência tem um o papel de construir e perpetuar modelos de ordem e essa ordem é feita à custa do diferente e em uma sociedade ocidental com estruturas patriarcais o diferente é a mulher e a ciência ao não incluir a condição acaba contribuindo e perpetuando essa condição de gênero.

Para as autoras Neves e Nogueira (2003) a psicologia feminista é um instrumento para a mudança social assumindo um papel fundamental no ativismo social contribuindo para que mulheres possam se empoderar, desconstruindo as relações de poder de gênero e construindo uma psicologia mais ampla e que inclua todas as vivências e indivíduos, e ao compreender a condição de gênero a psicologia desconstrói a estrutura patologizante que influência a condição feminina.

Os objetivos da psicologia feminista para Neves e Nogueira (2003) é a mudança social, rompendo com as hierarquias de gênero dando voz aos oprimidos e legitimando as construções de realidade de cada um e dentro delas fazer transformações.

Beauvoir (2016) através da afirmação "a mulher livre está apenas nascendo" isso significa que por mais que as mulheres já tenham alcançado muitos lugares através de suas lutas, reivindicaram direitos. Porem a liberdade de fato está apenas nascendo, ainda existem muitas lutas a travar para poder dizer que as mulheres possuem a liberdade, e que vivem uma realidade sem opressões, desigualdades e violências. Porém as pesquisas e estudos feministas são um caminho para essa liberdade da marcação de gênero.

\section{CONSIDERAÇÕES FINAIS}

Partindo da perspectiva dos estudos de gênero a condição de gênero é uma marca muito influente na construção humana, construção social e subjetiva. Compreender gênero é fundamental para entre a experiência do sujeito, as vivências de homens e mulheres são distintas com símbolos e significados diferentes. A construção de gênero cria uma hierarquia de poder social em que homens são superiores as mulheres gerando uma realidade de desigualdades em que a mulher é excluída, oprimida e está vulnerável a diversas situações de violências.

Dentro desse contexto essa pesquisa procurou da voz a uma realidade que muitas vezes é excluída a condição de gênero feminina. Esta pesquisadora teve a honra de apresentar uma pesquisa dentro do tema, com um posicionamento político e social feminista construir essa pesquisa e perceber que o movimento e as teorias feministas fazem parte da construção de uma ciência justa. Esta se sentiu feliz e satisfeita com a possibilidade de desenvolver um tema que para muitos pode parecer desnecessário mas através da pesquisa é possível perceber a importância do tema, e este deveria ser mais presente na academia e nos 
campos profissionais já que é algo que não tem como fugir a marca do gênero acompanha cada indivíduo e tem grande influência sobre a sua vida.

A condição de gênero é a marca do seu gênero e como ela te afeta e todas as áreas da sua vida ser, o gênero vai definir muita coisa na vida do indivíduo mesmo que esse não perceba, essa definição não é natural, é uma construção sociocultural em que a cultura em que o indivíduo está inserido vai definir e ensinar quem ele deve ser. Essa condição constrói várias desigualdades, o gênero é uma marca social da desigualdade, uma hierarquia de poder em que um possui mais poder que outro e esse outro inferior é a mulher a condição de gênero feminina é uma realidade de opressão e violência.

Diante dessa situação não é incomum que surjam sofrimentos psíquicos nessas mulheres devido as situações que fazem parte da realidade feminina. E a pergunta que ficou é onde está a psicologia diante dessa realidade de desigualdades. A psicologia por muito tempo escolheu ficar neutra diante da condição de gênero permitindo que as desigualdades continuassem, e como crítica a essa posição e como nova visão para descontruir o patriarcado surge a psicologia feminista que tem um papel social fundamental que é a desconstrução da desigualdade e violência, construindo um ciência inclusiva que procura romper com as desigualdades sociais e seus efeitos na saúde mental, considerando em especial a condição feminina que por muito tempo foi excluída da ciência e que tem um realidade mais vulnerável com constante violação de seus direitos, e como princípio fundamental presente no código de ética a atuação psicológica é embasada na declaração universal dos direitos humanos ou seja a psicologia se opõem a qualquer violação de direitos, com responsabilidade social de criticar a realidade histórica, social e cultural.

Um tema que possui uma certa dificuldade pela falta de conteúdo e pelos estereótipos que esse tema carrega. 0 tema gênero é tão escasso que por muitos é considerado novo e atual, e sim é novo é atual e é autentico, mas que tem um caminho longo na ciência está a décadas dentro das pesquisas, academias e atuações profissionais de forma discreta, mas está presente. A crítica feminista está na ciência desde a década de 70, através das questões levantada pelas mulheres e o desejo de se compreenderem e mudar a realidade destinadas a elas, as mulheres ocuparam a ciência em diversas áreas humanas, sociais e mais recente as áreas da saúde.

Essa é uma pesquisa curta com poucas referencias limitada a produções em português e como sugestões para mudanças e melhorias para esta pesquisa uma maior profundidade teórica sobre o tema, assim como uma delimitação maior podendo assim trazer a diversidade das realidades femininas diversas, e por fim na perspectiva desta pesquisado como futura psicóloga uma análise fenomenológica poderia aproveitar melhor o tema através de seus métodos e compreensão do sujeito.

A importância da temática deste trabalho é reforçada pela potência de mudança e transformação social que a entrada do feminismo na psicologia possui sendo uma crítica a estrutura patriarcal opressiva presente na cultura ocidental como a brasileira.

Por fim considera-se que a condição de gênero é um fator significativo na experiência humana, a experiência de sofrimento psíquico não é diferente esse sofrimento pode ter origem na condição de gênero em especial as mulheres que ocupam um lugar de inferioridade na hierarquia de gênero, esse tema não se encerra aqui dessa forma se faz necessário que novas pesquisas sejam realizadas e que este trabalho possa ser um ponto de partida para novas descobertas.

\section{REFERÊNCIAS}

[1] ALVES, Tahiana Meneses. Gênero e saúde mental: algumas interfaces. Working Papers série 2, no 3; CiCS. Nova - Universidade do Milho, 2017. Disponível <http://hdl.handle.net/1822/46599> Acesso em 23 out 2020.

[2] ANJOS, Karen Priscila Lima; LIMA, Maria Lúcia Chaves. Gênero, sexualidade e subjetividade: Algumas questões incômodas para a psicologia. 2016. Revista Psicologia em Pesquisa, UFJF. Volume 10, Número 2, p.49-56. 2016. Disponível <http://dx.doi.org/10.24879/201600100020059> Acesso em 12 set 2020

[3] BEAUVOIR, Simone. 0 segundo sexo: fatos e mitos - a experiência vivida, 3 ed. Rio de Janeiro: Editora Nova Fronteira, 2016. volume 1 e 2.

[4] BUTLER, Judith. Problemas de Gênero: feminismo e subversão da identidade. 16 ed. Rio de Janeiro: Editora Civilização Brasileira, Brasil. 2018. 
[5] CRUZ, Patrícia Maria Ferreira Amaral da. A depressão no feminino: 0 género e a doença como laboratório de laços sociais. 2009. Dissertação de Mestrado. Universidade do Minho, RepositóriUM. Disponível <http://hdl.handle.net/1822/10613> Acesso em 30 set 2020

[6] FÁVERO, Maria Helena; MARACCI, Inara Linn. A interlocução de narrativas: um estudo sobre papéis de gênero. Revista Psicologia teoria e pesquisa. UNB, v.32, n.2, p. 1-9. 2016 . Disponível <http://dx.doi.org/10.1590/0102-3772e322220> Acesso em 15 out 2020

[7] FERNANDES, Maria as Graças Melo; 0 corpo e a construção das desigualdades de gênero pela ciência. Physis: Revista em saúde coletiva. UERJ, v.19, n.4, p. 1051-1065. 2009.

[8] FLICK, Uwe. Introdução à pesquisa qualitativa. 3 ed. Porto Alegre: Artmed, 2009.

[9] GARCIA, Carla Cristina. Breve história do feminismo. São Paulo- Editora Claridade. 2011.

[10] Gil, Antonio Carlos. Métodos e técnicas de pesquisa social. - 6 ed. São Paulo: - Atlas, 2008

[11] GOFFMAN, Erving. Estigma: notas sobre a manipulação da identidade deteriorada. - 4 edição, Rio de Janeiro: LTC, 2008.

[12] GOMES, Gisele Ambrósio. História, mulher e gênero. Programa de Pós-Graduação em História da Universidade Federal de Juiz de Fora. 2011.

a. NARVAZ, Martha Giudice; KOLLER, Sílvia Helena. Feminismo e terapia: a terapia feminista da família - por uma psicologia comprometida. Revista Psicologia Clínica, Puc-Rio, v. 19, n.2, p. 117-131, Rio de Janeiro, 2007.

[13] NARVAZ, Martha Giudice; KOLLER, Sílvia Helena. Metodologias feministas e estudos de gênero: articulando pesquisa, clínica e política. Revista Psicologia em Estudo, UEM, v.11, n.3, p. 647-658. Maringá, 2006.

[14] NEVES, Sofia; NOGUEIRA, Conceição. A psicologia feminista e a violência contra as mulheres na intimidade: a (re)construção dos espaços terapêuticos. Revista Psicologia e Sociedade, v.15, n.2, p.43-64. 2003.

[15] NOGUEIRA, Coceição. Feminismo e discurso do género na psicologia social. Instituto de Educação e Psicologia, Universidade do Minho. 1999. Disponível < http://hdl.handle.net/1822/4117> Acesso em 12 set 2020 .

[16] NOGUEIRA, Conceição. Contribuições do contorcionismo social a uma nova psicologia do gênero. Instituto de educação e psicologia da universidade de milho-Portugal, Cadernos de Pesquisa, no 112, p. 137-153. 2001.

[17] PINHEIRO, Maria Joseilda da Silva. Gênero e feminismo no estado do amazonas: a luta por direitos dos movimentos de mulheres em Manaus. Seminário Internacional Fazendo Gênero 10, 2012.

[18] PREHN, Denise Rodrigues; HÜNING, Simone M. O Movimento feminista e a psicologia. Revista Psicologia Argumento, volume 23, número 42, p. 65-71. Curitiba - PR 2005.

[19] ROHDEN, Fabíola; BARRETO, Andreia; ARAÚJO, Leila; PADILHA, Heloisa; COUTINHO, Laura. Gênero e diversidade na escola: formação de professoras/es em gênero, orientação sexual e relações étnicos-raciais. livro conteúdo. versão 2009, rio de janeiro, CEPESC, Brasília, SPM, 2009.

[20] SAAVEDRA, Luísa; NOGUEIRA, Conceição. Memórias sobre o feminismo na psicologia: para a construção de memórias futuras. Universidade do Minho Portugal. p.113-127, 2006.

[21] SANTOS, Anna Maria Corbi Caldas dos. Articular saúde mental e relações de gênero: dar voz aos silenciados. Revista Ciência e saúde coletiva, volume 14 número 4,p. 1177-1182. 2009.

[22] SANTOS, Luana Carola dos; CARVALHO, Ana Berlado; AMARAL, Julião Gonçalves; BORGES, Larissa Amorim; MAYORGA, Claudia. Gênero, feminismo e psicologia social no brasil. análise da revista psicologia e sociedade (1996-2010). Universidade Federal de Minas Gerais. Minas Gerais - BR. 2016.

[23] SENKEVICS, Adriano Souza; POLIDORO, Juliano Zequini. Corpo, gênero e ciência: na interface entre biologia e sociedade. Revista da biologia, volume 9, número 1, p. 16-21. 2012.Disponível <https://doi.org/10.759/revbio.09.01.04> Acesso em 02 nov 2020 
[24] SWAIN, T. N. Entre a vida e a morte, o sexo. Revista Labrys Estudos Feministas, 2006. Disponível em: http://www.tanianavarroswain.com.br/chapitres/bresil/entre\%20a\%20vida\%20e\%20a\%20morte.htm.

[25] TIBURI, Marcia. Feminismo em comum para todas, todes e todos. 2 ed. Rio de Janeiro: Editora Rosa dos tempos.- BR. 2018.

[26] ZANELLO, Valeska. Saúde Mental e gênero. In: Mundos de mulheres no brasil. VEIGA, Ana Maria; NICHNIG, Claudia Regina; WOLFF, Cristina Scheibe; ZANDONÁ, Jair. Editora CRV Curitiba - Brasil 2019.

[27] ZANELLO, Valeska. Saúde mental gênero e dispositivos: cultura e processo de subjetivação. 1 ed. Curitiba: Editora Aprris 2018.

[28] ZANELLO, Valeska; FIUZA, H. Gabriela; COSTA, Humberto Soares. Saúde mental e gênero: facetas gendradas do sofrimento psíquico. Revista de Psicologia, vol.27 no.3 p. 238-246, 2015. Disponível< http://dx.doi.org/10.1590/1984-0292/1483> Acesso em 21 out 2020

[29] ZANELlO, Valeska; SILVA, René Marc Costa da. Saúde mental, gênero e violência estrutural. Revista Bioética, v.20, n.2, p.267-279. 2012. 


\section{Capítulo 3}

\section{O suicídio e os fatores de risco em adolescentes}

\section{Antônia Batista Mendes de Sá}

Resumo: 0 presente trabalho refere-se ao suicídio e aos fatores de risco em adolescentes, tendo como objetivo compreender o fenômeno do suicídio em adolescentes. Falar sobre suicídio é algo complexo, bem como os fatores que podem levar uma pessoa a cometer tal ato e quando se refere a adolescentes, essa complexidade se torna mais intensa, levando em consideração que a adolescência é um período de inúmeras mudanças, tanto biológica quanto social. Quanto à metodologia, foi desenvolvido em forma de pesquisa bibliográfica qualitativa sistemática, na qual implicam que os dados e informações necessárias, sejam obtidos através do levantamento de pesquisas bibliográficas por meio de livros, artigos científicos, sites especializados, monografias, TCCs, revistas especializadas entre outros, cujos estudos foram expressos a partir de visões específicas para geral. Os instrumentos utilizados para a realização da pesquisa foram o Google acadêmico, biblioteca virtual em saúde (BVS), Scientific Electronic Library Online SciELO. Nesta pesquisa, verificou-se que o suicídio é um problema complexo, por está relacionado a múltiplos fatores como biológicos, psicológicos, sociais, ambientais, familiares, culturais, entre outros. Enfatizando que os fatores por si só, não são suficientes para o suicídio, toda via, aliados a inércia e somados a depressão e outros fatores externos, podem gerar adolescentes mais vulneráveis e suscetíveis ao suicídio. Torna-se importante o esclarecimento sobre este fenômeno, para que se possa tanto entender os meios de prevenção, bem como dar apoio necessário e de forma assertiva aos adolescentes que se encontram em situação de vulnerabilidade.

Palavras-Chave: Suicídio; Adolescência; Transtorno; Fatores e Causas. 


\section{INTRODUÇÃO}

O estudo em questão visa abordar os fatores de risco que levam a prática de suicídio em adolescentes. Percebe-se que é um tema palpitante, pois exige critérios e principalmente especificidade, por se tratar de um tema que requer uma análise dos fatores que corroboram para desencadeamento da decisão de atentar contra própria vida. A adolescência é um período propenso aos pensamentos suicidas em virtude das mudanças que ocorrem durante a sua passagem.

Segundo a OMS (2006) existem diversos fatores complexos como: mudanças no humor, problemas sociais e comportamentais, uso de substâncias, associados a fatores como uma vida familiar conturbada, bullying, estresse, bem como baixo rendimento escolar, que podem desencadear sentimentos de desesperança e desamparo, resultando na tentativa de suicídio.

Observa-se que diversos fatores podem contribuir de forma negativa para o sofrimento psíquico na vida dos adolescentes, somam-se ainda, às várias mudanças que os mesmos vivenciam de forma abrupta, motivadas por um turbilhão de hormônios, desencadeando não só alterações físicas, como emocionais.

Por tanto, mesmo que o adolescente tenha uma boa saúde mental, as significativas mudanças que eventualmente ocorrem no período da adolescência, podem levar o adolescente a ter dificuldades de auto compreensão e um entendimento sobre o que acontecem a sua volta, como: transformações em seu processo de desenvolvimento, crise de identidade, tabus, incertezas, ansiedade, impulsividade e além de todos esses fatores estressores, se potencializados pela depressão, pode torna-lo mais vulnerável e suscetível ao suicídio.

É essencial que o adolescente perceba que há pessoas que se preocupam com os seus problemas, que se importam e que estão dispostas a lhe ajudar. Isso implica em ouvi-lo sem fazer juízos de valor, dar oportunidade para que o adolescente fale sobre as suas emoções, contribuindo para que o mesmo se sinta menos solitário e mais esperançoso.

0 estudo tem como objetivo geral, compreender o fenômeno do suicídio em adolescentes. De forma pormenorizada outros aspectos ainda como: Levantar a temática de suicídio e suas fases na adolescência; identificar os principais fatores relacionados ao suicídio em adolescentes; analisar ideação e comportamentos suicidas na adolescência; verificar o sofrimento psíquico nas manifestações suicidas em adolescente.

A escolha da pesquisa deu-se a partir da realização do estágio que ocorreu no sexto período, ocasião em que teve-se a oportunidade de ministrar palestras em algumas escolas públicas do ensino médio, a respeito dessa temática e em virtude do qual se pôde ter a percepção em relação aos seus diversos aspectos e de que os mesmos deveriam ser analisados de forma mais detalhada e com mais atenção.

No que tange à relevância para a sociedade, este trabalho demonstrou que, tanto a família, quanto a escola, precisa estar preparada, disposta e atenta aos menores sinais para lidar com a problemática e para encaminhar o adolescente a um tratamento que trará um novo olhar sobre a vida e a vontade de prosseguir. Além disso, proporcionou a reflexão sobre suicídio e também uma análise dos motivos pelos quais este fenômeno tem sido silenciado ao longo dos anos, camuflando assim, um grave problema de saúde pública no Brasil e no mundo. Falar sobre o suicídio para a sociedade implica em quebrar tabus, além de instrumentalizar pais, instituição e a sociedade como um todo a lidar com este fenômeno.

No que se refere à contribuição para a ciência, este trabalho, pode acrescentar novos conhecimentos para os acadêmicos, podendo se utilizada como nova fonte de pesquisa, agregar conhecimento aos pesquisadores e acadêmicos a cerca do tema em questão, além de poder contribuir para a elaboração de novas pesquisas científicas, aprimorando o conhecimento sobre a temática.

Quanto à importância da pesquisa para aos acadêmicos de psicologia, faz-se de extrema importância para que os mesmos ampliem o conhecimento dobre este fenômeno, para que no exercício de sua profissão o acadêmico possa saber lidar com aspectos teóricos a respeito desta problemática, podendo corroborar com a sociedade e ao meio em que estar inserido, ressaltando que os profissionais de psicologia não se devem restringir-se somente à prevenção, mas preocupar-se em como lidar com o impacto causado pelo suicídio.

Quanto à relevância para o leitor, esta pesquisa visa resgatar este tema, definir parâmetros de alerta à sociedade, aos acadêmicos, aos pais e todos os envolvidos. Ressaltando a importância em reconhecer tais fatores, para que se tenha mudança de postura e para que se possa proporcionar um atendimento adequando, transmitindo aos adolescentes a mensagem de que há sempre outras formas de solucionar os seus problemas, ressaltando que o suicídio não é uma delas. 


\section{REFERENCIAL TEÓRICO}

\section{Suicídio}

Segundo Botega (2006) o suicídio é referido pela literatura especializada, como uma demanda complexa de saúde pública, visto que, com base em estatísticas mundiais, há a ocorrência de um suicídio a cada 40 segundos. Cruz e Camargo (2017) salientam que, o termo suicídio tem origem no latim, na junção das palavras sui (si mesmo) e caedere (ação de matar), ou seja, é um ato que consiste em por fim, intencionalmente, à própria vida, é um ato voluntário em que o indivíduo, por motivos como, elevado grau de sofrimento, descontrole emocional, decepções, transtornos mentais e de ansiedade, vê na morte a solução de seus problemas.

Closs (2015) abordam que, o suicídio (de sui, a si próprio; caedere, cortar, matar), como uma deserção voluntária da própria vida; é a morte, por vontade e sem constrangimento, de si próprio. Suicida é todo aquele que deliberadamente consuma a própria morte; é o que destrói livremente a própria vida.

Borges e Werlang (2006) salientam que, a expressão suicida, se refere aos pensamentos de autodestruição e ideias suicidas, englobando desejos, atitudes e planos que o indivíduo tem para dar fim à própria vida.

Segundo Moreira e Bastos (2015) a morte é temida pela maioria das pessoas; entretanto, pode ser considerada como um alívio para aqueles que não encontram alternativas para seus problemas, e buscam por meio de comportamentos autodestrutivos, acabar com a própria vida.

\section{Suicídio na adolescência}

Segundo Faria (2014) a palavra adolescência, tem sua origem no Latim "ad" (para) + "olescere" (crescer). Por esta razão, adolescência significaria, strictu sensu, crescer para. A etimologia da palavra remete à ideia de desenvolvimento, de preparação para o que está por vir, de mudança e de transformação.

No Brasil, o Estatuto da Criança e do Adolescente (BRASIL [ECA], 1990), define o adolescente como o indivíduo entre 12 e 18 anos. A Organização Mundial da Saúde (World Health Organization - WHO, 2010), descreve esta etapa do ciclo vital como a transição entre a infância e a idade adulta e a define como o período entre 10 e 19 anos. Apesar das divergências a respeito do período exato que compreende a adolescência, esta tem sido considerada um fenômeno universal (Knobel, 1981) relata as experiências vividas nesta fase possuem fundamental importância para o desenvolvimento subseqüente (BRAGA, 2011, p.9).

De acordo com a cartilha de prevenção ao suicídio, voltada para conselheiros publicada em 2006 pela OMS, a adolescência é uma fase propensa aos pensamentos suicidas devido às mudanças, que ocorrem durante a sua passagem. Fatores complexos como as mudanças no humor, problemas sociais e comportamentais, o uso de substâncias, associados a fatores como uma vida familiar conturbada, bullying, estresse e baixo rendimento escolar, podem acarretar em sentimentos de desesperança e desamparo, resultando na tentativa de suicídio. (OMS, 2006).

Roskosz, Chaves e Soczek (2017) alegam que, os adolescentes que praticam ato suicida, estão relacionados ao histórico de doenças psiquiátricas na família, negligência ou abuso sexual na infância, baixo nível de apoio parental, problemas com a lei ou disciplinares, contato com armas de fogo, abuso psicológico por parte de colegas ou familiares, tentativa anterior e suicídio de familiares ou conhecidos.

Moreira e Bastos (2015) citam que, o momento de passagem da infância para adolescência, gera problemas existenciais, que podem levar os adolescentes a apresentarem pensamentos suicidas em baixa frequência e de forma esporádica. Isso é caracterizado como parte normal do processo de entender o significado da sua existência ou da sua morte, além disso, nessa fase, existe a dependência e a independência extremas e esses anseios podem ou não ser relatados a família. 


\section{Fases suicidas}

Berti (2010) alega que, a tentativa de suicídio no comportamento não fatal, auto infligindo é potencialmente danoso e com qualquer intenção de morrer, uma vez que uma tentativa de suicídio pode resultar ou não em um ferimento.

Conwell (2015) aborda que o ato suicida, compreende o comportamento auto infligido, potencialmente danoso, com qualquer intenção de morrer como seu resultado. Um ato suicida por resultar ou não em morte (suicídio).

Araújo, Vieira e Coutinho (2010) acreditam que existe ambivalência no comportamento dos indivíduos, pois, com a intenção de acabar com a dor psíquica em algum momento em suas vidas, se sentem confusos em relação aos seus pensamentos, com o desejo de viver ou morrer e desta forma vivem, em uma indecisão.

Daber e Baptista (2004) salientam que a impulsividade é um momento transitório, que por alguns pontos negativos, criam ideia fixa constante no dia a dia, durando alguns minutos ou horas, que é gradualmente aumentada, resultando um impulso brusco e irreversível. A impulsividade é uma característica da fase da adolescência.

Entre os adolescentes as ideações, planos e tentativas de suicídio, embora ideações e planos sejam temporários nos jovens, diferentemente ao que ocorre com os adultos. Nos adultos o papel dos transtornos mentais no comportamento suicida tem influencia maior e que entre os jovens estes tem papel menos importante. Nos jovens, o mais importante e que merece destaque é a impulsividade. Assim, conflitos ou eventos conflitantes ou estressantes podem desencadear os eventos suicidas. Muitos jovens que tentam o suicídio relatam que passaram apenas alguns minutos entre a decisão e a tentativa (FARIA 2014, p.10).

\section{Fatores relacionados ao suicídio em adolescentes}

Existem diversos fatores que podem contribuir para os adolescentes atentarem contra a a própria vida, justamente no memento de descobertas, crescimento físico e intelectual. Estudos mostram que os fatores e situações que podem levar o adolescente a cometerem o suicídio são multifacetados e podem estar associados a fatores familiares, culturais, sociais, psicológicos entre outros, contribuindo para o agravamento da saúde mental dos adolescentes.

O suicídio é um problema complexo para o qual não existe uma única causa ou uma única razão. Ele resulta de uma complexa interação de fatores biológicos, genéticos, psicológicos, sociais, culturais e ambientais. É difícil explicar porque algumas pessoas decidem cometer suicídio, por um determinado motivo. Contudo a maioria dos suicídios pode ser prevenida. Suicídio é agora uma grande questão de Saúde Pública em todos os países. Capacitar a equipe de atenção primária à saúde para identificar, abordar, manejar e encaminhar a pessoa que está em sofrimento psíquico é um passo importante na prevenção do suicídio. É importante considerar que esses aspectos, isoladamente, não são preditores do suicídio, mas as consequências deles derivadas podem aumentar a vulnerabilidade dos indivíduos ao comportamento suicida (BERTOLOTE, 2000, p.4).

Segundo Freitas e Botega (2002) no Brasil, à gravidez em adolescentes atendidas em serviço público para a realização do pré-natal, associadas a estresse, impulsividade, transtorno de humo e de personalidade, abuso sexual ou físico, violência intrafamiliar, abandono, isolamento social, transtorno mental, uso de álcool e outras drogas podem potencializar o risco ao suicídio.

Além disso, Meneghel et al, (2004) salientam que, levando em consideração as suas repercussões, a gravidez na adolescência é um fator de risco ao suicídio e que a ideação suicida está associada a depressão.

Prieto e Tavares (2005) enfatizam que, a presença de desordem psiquiátrica como esquizofrenia, uso de substâncias, transtorno de personalidade e de humor, tem demonstrado correlação com comportamento suicida. 
Conforme Braga (2011) a vulnerabilidade desencadeada pelas situações de pobreza, é uma situação social que pode contribuir para o comportamento suicida, visto que o desemprego, o estresse econômico e a instabilidade familiar aumentam o nível de ansiedade dos indivíduos.

Araújo, Vieira e Coutinho (2010) salientam que, indivíduos com histórico de suicídio na família, possuem maior risco para repetição do comportamento, verificando-se desta forma, a transgeracionalidade do comportamento suicida. Para Toro et al (2009) alegam que, fatores como, perdas recentes de um ente querido e tentativas prévias de suicídio, contribuem de forma significativa para o aumento de suicídio.

Bella, Fernández e Willington (2010) abordam as tentativas prévias de suicídio, como o fator de risco mais importante para predizer novos comportamentos suicidas em adolescentes. Mercy et al (2001) enfatizam que, o comportamento de imitação ou contágio, está relacionado ao conhecimento de uma pessoa que cometeu o suicídio e é um dos fatores que contribuem para o aumento de suicídio. Vale ressaltar que, o conhecimento de suicídio de pessoas famosas veiculados na mídia, pode contribuir para o comportamento de imitação.

Nesse sentido, Werlang, Borges e Fensterseifer (2005) alegam que, segundo alguns estudiosos, o impacto que as notícias de suicídio veiculadas através da mídia, têm sido destacadas como sendo um importante fator de risco ao suicídio.

Segundo Daber e Baptista (2004) várias pesquisas tem comprovado a existência do fenômeno suicídio, principalmente em adolescentes e adultos jovens, onde os mesmos são influenciados por divulgação de comportamento de pessoas que cometeram suicídio, ressaltando que pessoas com problema de saúde mental, estão mais vulneráveis a comportamentos de imitação.

O suicídio é um fenômeno complexo que envolve múltiplas causas e que afeta, além de suas vítimas, os sobreviventes. Envolve também profissionais de saúde e de outros setores que direta ou indiretamente lidam com o problema no seu cotidiano. A partir do funcionamento de uma rede de vigilância, prevenção e controle, é possível que vários profissionais possam compartilhar informações referentes à abordagem, ao acolhimento e ao tratamento das pessoas em situação de vulnerabilidade. Portanto, é necessária a participação de todos na sua prevenção. (MOURA, 2011, p.23).

Para Daber e Baptista (2004) pessoas que estão procurando solução para seus problemas, podem ser influenciadas através da mídia, ao se depararem com casos de suicídio, divulgados em jornais, televisão ou internet e a vulnerabilidade aumenta, quando se refere a adolescentes ou jovens com problemas psíquicos ou mentais.

Bahls e Barls (2002) enfatizam que, os casos de suicídio podem ser potencializados, se o adolescente presenciar história de suicídio de um familiar ou de pessoas conhecidas, podendo reproduzir comportamento aprendido, como forma de resolução para seus conflitos, resultando na expansão de ocorrências de suicídio através das gerações.

Kinyanda et al (2011) salientam que, as diferenças geográficas na incidência do comportamento, podem ser elucidadas pelas desigualdades de privação social e doenças psiquiátricas e esses fatores podem ser associados à história de comportamento suicida em adolescentes de diferentes zonas rurais, em virtude da dificuldade de acesso ao tratamento dessas doenças nas regiões rurais.

Kruger e Werlang (2010) também afirmam que, indivíduos que vivem em áreas rurais são mais propensos a tentarem suicídio, se comparados indivíduos que vivem nas zonas urbanas, esse resultado pode ocorrer em virtude de indivíduos que residem na zona urbana, ter mais acesso a cuidados de saúde mental e suporte social. Vale ressaltar que o isolamento social pode ser considerado um fator de risco ao suicídio.

\section{Fatores sociodemográficos}

Os fatores sociodemográficos compreendem a idade, gênero, religião, espiritualidade; fatores da esfera suicida; história de tentativas de suicídio prévias; plano suicida e acesso a meios letais. Mendonça (2015) salienta que as taxas de suicídio referentes a jovens, têm seus números acrescidos no mundo. No Brasil, ocupa o terceiro lugar, concernentes a fatores de risco para a causa de morte, tendo na impulsividade, 0 aliado aos eventos socioculturais que expõe os jovens aos transtornos adquiridos durante o processo de crescimento como pessoa. 
Para Jucáa e Vorcarob (2018) a automutilação em jovens por não se sentir parte de algum grupo social é um fator preocupante no decorrer dos anos, estes jovens adquirem formas mais eficientes para se tornar um potencial suicida. Concentrando maior índice aos 40 anos e que devido a fatores estressantes ou ambientais se torna ao seu entendimento a única solução para uma dúvida adolescente.

Segundo Conwell (2015) a morte precoce desejada por alguns idosos pode se confundir com a intenção de suicídio, mas apesar de parecer sinônimos, tem conotações diferentes podendo ter diagnósticos equivocados.

Kuczynski (2014) salienta que, o comportamento suicida na faixa etária de 12 anos, é menos provável, mas pensamentos mórbidos podem ocorrer frequentemente. 0 índice em alta, entre jovens e adolescentes é evidente, podendo ser acompanhado de impulsividades comportamentais de autodestruição.

Segundo Ribeiro (2003) o aspecto suicida identificado nos problemas situacionais no adolescente, não tem maior relevância para cometer o suicídio no adulto o risco aumenta com a idade. Com outro argumento Pinto, Alves e Maia (2015) abordam que, o fator gênero, em diversos países, tal como em Portugal, as taxas de suicídio dos indivíduos do gênero feminino são três vezes menores, entre 6 a 10 anos de idade, do que a do gênero masculino, com exceção da China.

Por outro lado, Godoy (2018) alega que, contrariamente à ideação suicida e às tentativas de suicídio, onde as mulheres lideram, principalmente após a puberdade, com uma probabilidade dez vezes maior de realizar tentativas de suicídio. Daudt, Souza e Sperb (2007) abordam que, outros fatores no aumento do suicídio entre as mulheres chinesas, podem estar relacionados com a disrupção e a marginalização da mulher, consequência da transição de uma sociedade tradicional agrária para uma sociedade capitalista e urbana.

Mendonça (2015) salienta que, ao que se refere à religião e espiritualidade, alguns estudos demonstraram uma menor frequência de comportamentos suicidários. Além da religião e espiritualidade a raça e etnia são fatores também importantes.

Daudt, Souza e Sperb (2007) abordam que, outros fatores no aumento do suicídio entre as mulheres chinesas, podem estar relacionados com a disrupção e a marginalização da mulher, consequência da transição de uma sociedade tradicional agrária para uma sociedade capitalista e urbana.

Daber e Baptista (2004) salientam que, no plano suicida, existe uma associação positiva entre um plano suicida e um método com letalidade superior, com um maior risco de suicídio. A letalidade refere-se, ao potencial de perigo de morte associado ao método utilizado; tal torna a utilização de arma de fogo, a precipitação de alturas ou o enforcamento, métodos de alta letalidade. Os indivíduos que tentam se suicidar com uma alta letalidade médica, encontram-se em risco elevado para cometer suicídio.

Mendonça (2015) alega que, o acesso aos meios letais, a acessibilidade aos meios que oferecem risco, é um importante facilitador do suicídio. Muitos dos atos suicidas em jovens demoram apenas alguns minutos entre a decisão e o ato suicida, indicando um grau elevado de impulsividade. Estes suicídios impulsivos utilizam métodos normalmente mais violentos, como armas de fogo, enforcamento e precipitação de alturas.

Logo, Moura (2011) cita que, é importante restringir o acesso a métodos altamente letais, para prevenir o suicídio nos adolescentes e adultos jovens. Em suma, a presença de armas de fogo em casa, e de outros meios letais como medicamentos e a supervisão parental inadequada aumentam o risco de suicídio.

Segundo Conselho Federal de Psicologia (2013) diversos fatores protetores que são semelhantes aos da população em geral, porém com mais relevo para os adolescentes incluem: a. Fatores familiares: cuidados parentais mantidos, coesão familiar, capacidade de envolvimento mútuo, partilha de interesses e suporte emocional; b. Fatores individuais: capacidades de resolução dos problemas, sentido de valor pessoal, abertura para novas experiências e projetos de vida e a não utilização de substâncias nocivas; e c. Fatores sociais: pertença a um ambiente escolar positivo, boa relações com amigos e colegas, boas relações com professores e outros adultos, suporte dos pares e valores culturais ou religiosos.

\section{Fatores culturais}

Closs (2015) alega que, o fenômeno suicídio, não só mobiliza as emoções coletivas de uma sociedade, como adquire uma dimensão política, ideológica e social em torno da perspectiva de vida, levando em consideração que diversos fatores de contexto não permitem que essa perspectiva seja desenvolvida plenamente. 
Segundo Cruz e Camargo (2017) os profissionais que intervêm no processo de condutas suicidógenas, tem em mente, a necessidade de observar o conjunto das emoções na história de vida pessoal e coletiva da população como um bem social indispensável.

Mendonça (2015) aborda que, o suicídio nas populações indígenas - em especial as que possuem altas taxas, talvez as maiores do Brasil, como o Guarani Kaiowá - é altamente significativo como expressão do mal estar social, mas essa situação não é exclusiva dos povos indígenas. Esse fenômeno é observado em diversos setores sociais no país.

\section{Fatores psicológicos}

Para Moura (2011) o luto, é da própria concepção do suicídio. Determinadas concepções culpabilizam as pessoas em torno do suicida, o estigmatizam, de forma que os enlutados sofrem esse estigma, sentem-se envergonhados.

Pinto, Alves e Maia (2015) enfatizam que, o abuso físico e emocional, os maus tratos que incluem o abuso sexual, físico, emocional e a negligência estão associados com a ideação suicida e às tentativas de suicídio. O abuso sexual é definido como um contato forçado ou uma conduta sexual inapropriada que envolve contato entre um adulto e uma criança.

Já para Conwell (2015) o abuso emocional é algo difícil de categorizar nas outras formas de abuso, pois é mais subjetivo inclui insultos verbais ao bem estar ou à autoestima, ou qualquer ameaça ou humilhação, entre outros, por um adulto.

Segundo Berti (2010) a negligência é definida como uma falha dos progenitores em saber quais são as necessidades físicas básicas da criança, como sejam alimentação, abrigo, segurança e supervisão, não esquecendo as necessidades psicológicas e emocionais.

Dutra (2002) salienta que, tal como os comportamentos suicidas, os maus tratos não são incomuns nas amostras comunitárias significativas. 0 abuso físico e sexual, particularmente tardio nos adolescentes, está associado fortemente a uma história de tentativa de suicídio, bem como de suicídio.

Borges, Werlang e Copatti (2008) reforçam que o abuso na infância, aumenta três vezes a probabilidade dos adolescentes ficarem deprimidos ou com comportamentos suicidas, do que aqueles sem qualquer história de abuso. Há evidências que sugerem que o abuso sexual e emocional são fatores de risco mais importantes relativamente ao abuso físico e negligência. Existe também um efeito aditivo para cada forma de maus-tratos.

0 bullying é um tipo de violência exercida entre pares em contexto escolar, ou mesmo nos arredores da escola e vizinhança, que deriva de bully que significa valentão, estando o termo relacionado com agressividade e vitimização. Tratasse de comportamento agressivo exercido por um indivíduo ou grupo de indivíduos sobre outro indivíduo ou grupo, havendo uma desigualdade de poder é realizado de forma intencional e repetitiva ao longo do tempo sem razão aparente. (ARAÚJO; VIEIRA; COUTINHO, 2010, p.13)

Segundo Assis (et al., 2006), os adolescentes que são vítimas do bullying normalmente tem dificuldades para se defenderem frente as situações agressivas que são submetidas e esse fato pode ocasionar em evasão escolar, levando em consideração que muitas vezes, as vítimas consideram a pressão insuportável. 0 bullyng é um assunto bastante divulgado mundialmente, discutidos nas escolas, em universidades, academias e em redes sociais e por suas consequências na maioria das vezes serem bastante traumáticas, faz-se necessário maior atenção e um profundo conhecimento do que seja bullyng e todos os fenômenos que o cercam.

\section{Fatores psicopatológicos}

Conforme Dutra (2002) o alcoolismo está presente em 85\% das mortes por suicídio, para cada 100 notificações, e associada com a depressão forma uma combinação fatal. A dependência do álcool tornou-se ponto de discussão, sendo citado entre as maiores causas de tentativas de suicídio.

Para Chaplin et al (2014) o consumo de álcool, tabaco e de drogas ilícitas na adolescência podem levar o adolescente à dependência química, somando-se a vários comportamentos de risco e ao desenvolvimento de sintomas emocionais e comportamentais. 
O álcool enfraquece mecanismos de controle da mente, deprimindo o indivíduo deixando-o

Mais suscetível a cometer suicídio, interagindo com a auto estima rebaixando a confiança em si mesmo, levando este indivíduo a ter incertezas do futuro, tornando mais irritado, e em alguns casos acomete automutilação e o extermínio de si próprio. Ainda discutindo sobre este assunto, o alcoolista adquire um quadro depressivo em $70 \%$ dos casos e $15 \%$ daqueles que estão inseridos em hospitais atentam contra a própria vida. 0 consumo de substâncias ilícitas impulsiona o mercado da interação social, onde a dependência química e o consumo de bebida alcoólica produzem vítimas que tem inúmeras dificuldades em conseguir uma próxima dose, tendo reflexo negativo, onde a convivência se torna insustentável para o vício e para o vínculo familiar deixando o usuário pré disposto a um ato de inexistir, um sentimento de alívio para os seus problemas e para sua família. (BERTI, 2010, p.25).

Moreira (2011) alega que, em virtude da insegurança de não satisfazer as expectativas dos pais, usuários de substâncias químicas, atentam contra a própria vida, como forma de não mais preocupar seus entes familiares sobre o uso das drogas. Os fatores de origem biológica e socioculturais, associados à depressão e ao consumo de álcool e drogas podem culminar em diversas tentativas de suicídio.

Faria (2014) aborda que, a complexidade que este assunto transcreve, teria no seu tratamento igual teor de complexidade. A negligência possibilita o aumento da dependência do consumo de substâncias entorpecentes e problema de ordem pública tem dificuldades em fazer acompanhamento do tratamento corretamente.

A doença bipolar não é apenas uma única perturbação, mas uma categoria de perturbações ao longo da vida caracterizado por um ou mais episódios recorrentes de mania, hipomania ou depressão. A perturbação bipolar na população pediátrica é um problema de saúde pública que afeta $1,8 \%$ da população nos Estados Unidos da América e, tem sido associada com taxas de suicídio entre 20 a 44\%. Os fatores de risco de suicídio nas perturbações bipolares podem ser categorizados em quatro grupos: demográficos (idade e gênero), clínicos (depressão, mania, perturbações de ansiedade, sintomas psicóticos e abuso de substâncias), psicológicos (desesperança, baixa autoestima, impulsividade e agressividade, história de ideação suicida prévia, hospitalizações psiquiátricas anteriores, entre outros) e familiares/sociais (história familiar de tentativas de suicídio, de depressão e de maus-tratos, entre outros). Nos indivíduos com perturbação bipolar, a primeira tentativa de suicídio ocorre mais prematuramente, relativamente aos indivíduos que têm uma perturbação depressiva major. (MERCY, et al, 2001, p.89).

Segundo Daudt, Souza e Sperb (2007) o gênero, também pode ser relevante nestes indivíduos, pois indivíduos do gênero feminino poderão ter um risco acrescido. Os comportamentos suicidas também estão mais associados com a mania, do que com episódios de depressão e hipomania. E os sintomas psicóticos representam também um risco acrescido de ideação suicida e plano suicida comparativamente com os jovens com perturbação bipolar sem sintomas psicóticos.

Prieto e Tavares (2005) salientam que, a esquizofrenia é a principal causa de morte prematura associada pelo suicida nos doentes com esquizofrenia, aproximadamente 2 a $5 \%$, ao contrário dos clássicos $10 \%$, cometem suicídio. Estudos revelaram uma relação fraca entre comportamento suicida e eventos de vida estressantes em doentes com esquizofrenia relativamente aos que não tinham.

Bertolote (2000) aborda que, em adolescentes com esquizofrenia, os comportamentos suicidas estão menos associados com os eventos de vida e mais com a percepção dos eventos como negativos e o impacto destes no indivíduo. Vários fatores de risco estão implicados no suicídio de indivíduos com esquizofrenia. 0 risco suicida nestes casos está associado principalmente a sintomas afetivos, a uma história de tentativa de suicídio prévia e ao número de internamentos psiquiátricos.

Conwell (2015) cita que, outros fatores de risco identificados foram idades mais jovens, a proximidade com o início da doença, a idade avançada no início da doença, gênero masculino, abusa de substâncias e o período durante e após um internamento psiquiátrico, além da má adesão ao tratamento. 
Prieto e Tavares (2005) abordam que, pessoas com esquizofrenia tem uma tendência a não transmitir a ideação suicida, que é um fator de risco comum para a maioria das outras condições psiquiátricas. Logo, os fatores de risco de suicídio conhecidos, parecem ser mais relevantes para indivíduos sem esquizofrenia.

As perturbações alimentares: é a anorexia e a bulimia nervosas, partilham muitos fatores de risco de suicídio. Nas últimas décadas houve um decréscimo no risco de suicídio para a anorexia nervosa, apesar de ainda continuar com taxas de suicídio superiores às da população em geral. Isto é atribuído a uma melhoria na detenção dos casos de anorexia nervosa que necessitavam de tratamento na seqüência da melhoria dos critérios de diagnóstico, na redução do estigma contra o tratamento das perturbações mentais, e pelo aumento dos especialistas na área das perturbações alimentares. Importa referir que as perturbações alimentares. (MOREIRA; BASTOS, 2015, p.212).

Cruz e Camargo (2017) alegam que, a perturbação de hiperatividade/déficit de atenção (PHDA) e o suicídio a PHDA refere-se a um comportamento hiperativo, desatenção, dificuldade em concentrar-se, impulsividade, num grau que é considerado inadequado para a sua idade e para o seu nível de conhecimento, que interfere com a capacidade da criança em aprender, realizar as atividades diárias, interagir com a sua família e com os outros.

Segundo Moreira e Bastos (2015) os indivíduos com PHDA, tem um risco maior para comorbilidades psiquiátricas associadas. Enquanto em crianças, os sintomas da PHDA, foram associados com perturbações de ansiedade, alterações de humor e perturbações de comportamento, em adolescentes foram associadas mais a perturbações de tiques, abuso de substância e dependência.

No entanto, para Berti (2010) existe em ambos, uma elevada prevalência em crianças e adolescentes, de ideação suicida, o que torna importante o rastreio nesta população de ideias suicidas o que consiste:

As perturbações de ansiedade, especialmente em comorbilidade com depressão, têm sido identificadas como aumentando o risco de comportamentos suicida. Além das perturbações psiquiátricas, existem características da personalidade que podem ser consideradas fatores de risco ou de proteção. Os níveis aumentados de neuroticismo, mais comum na adolescência que na vida adulta e no gênero masculino, constituem o comportamento suicida. Além deste fator, outros fatores de risco para o comportamento suicida como a ansiedade, a introversão, a agressividade, a impulsividade, a desesperança, a auto-crítica, o perfeccionismo, o sentimento de culpa e a irritabilidade. (BERTI, 2010, p.54).

\section{Ideação e comportamentos suicidas na adolescência}

Araújo, Vieira e Coutinho (2010), salientam que, a palavra ideação suicida, refere-se ao desejo consciente de morrer e a clara noção do que o ato executado pode gerar. Tendo seu início, na ideação do desejo de atentar contra a sua própria vida, podendo culminar na consumação do ato. A ideação suicida, portanto, refere-se à ideia ou ao pensamento que o individuo tem de se matar.

Werlang, Borges e Fensterseifer (2005) destacam que um importante preditor ao risco de suicídio é a ideação suicida, considerada como antecedente para a efetivação do ato suicida. Habitualmente, a decisão de praticar tal ato, pode vir precedida de manifestação de sinais relacionados à tentativa de suicídio.

Para Borges e Werlang (2006) a ideação abrange planos, atitudes e desejos que a pessoa tem sobre a própria morte e pode ser considerada um fator de risco para o suicídio efetivo quando soma-se com a depressão e a desesperança.

Segundo os pioneiros na pesquisa sobre suicídio, Werlang, Borges e Fensterseifer (2005), todo ato em que o indivíduo atenta contra a sua própria vida, independentemente da gravidade com que essa tentativa é realizada, considera-se uma ação suicida, que pode ser: ideação suicida, tentativa de suicídio e a consumação do ato, quando a tentativa é fatal.

Para Bahls (2002) a ocorrência de comportamentos suicidas entre jovens vem crescendo aparentemente nas ultimas décadas, aonde a adolescência vem ganhando destaque por ser um período de maior relação de mortes violentas. 
Braga (2011) ressalta que, após a primeira tentativa de suicídio, pode-se aumentar a probabilidade de ocorrer tentativas sucessivas culminando na consumação do ato. Desta forma, entende-se que é necessário que aja intervenção na trajetória entre tentativas e concretização da morte. Embora a morte ou a intenção de morrer seja algo tão temido, na maioria das vezes o adolescente vê a morte como alternativa para solucionar os seus conflitos.

Segundo Bastos e Moreira (2015) muitas vezes os adolescentes tem as atitudes que demonstram confronto, força, arrogância e poder, mas na realidade escondem em si, um pedido de atenção, de carinho, de limite e de proteção.

Levando em consideração a proporção com que essa problemática vem tomando entre adolescentes e jovens, se faz necessário que tanto a sociedade como a saúde pública, bem como os profissionais de saúde mental, ampliem os seus conhecimentos sobre este fenômeno, para que se possam dar mais atenção e para que se tenha melhor entendimento de como proceder diante de pessoas que se encontram em vulnerabilidade e que não conseguem administrar o seu estado emocional perturbador.

\section{O sofrimento psíquico nas manifestações suicidas em adolescentes}

Segundo Moreira e Bastos (2015) através do choque, pode-se observar sinais e sintomas físicos como aperto na garganta, mal-estar estomacal, diarreia, respiração ofegante.

Para Prieto e Tavares (2005) o alívio é um sentimento comum, quando os vínculos psicológicos e as relações cotidianas foram superficiais ou destrutivas, mas pode ser observado que esse estado pode ser seguido de um estado de choque.

Catarse é observada após o estado de choque uma etapa em que o conjunto das emoções é expresso, às vezes, de maneira incontrolável, com emoções sobrepostas - geralmente observado nos momentos relacionados ao funeral. Deve ser sublinhado que essa situação apresenta uma grande variação segundo as culturas e os tipos de rituais mortuários. A catarse pode também ser autorreprimida, mas em algum momento essa etapa estará presente. Pode ser estimulada como um momento importante para aceitação dos fatos, e clarear as dúvidas ou ajudar nas respostas que permitam elaborar o luto. Deve ser ressaltado que a catarse é também uma experiência angustiante. (BRAGA, 2011, p.61)

Faria (2014) aborda que, a depressão geralmente acontece após a descarga emocional, uma depressão nos desejos, e as emoções ficam menos intensas. Existe uma depressão reativa que é variável e depende da experiência de vida das pessoas. 0 período depressivo pode durar meses e varia segundo as respostas de cada pessoa, podendo durar anos naquelas que procuram o isolamento.

Para Ribeiro (2003) este estado deve ser entendido como uma injúria emocional e deve ser tratado nos primeiros meses, já que a ajuda externa é fundamental para superá-lo. A intervenção deve procurar evitar que se instale um quadro crônico para prevenir e impedir diversos comportamentos derivados desta situação, como autoagressivos dentre centenas de sintomas psicossomáticos (expressão física de sinais originada pelos estados emocionais).

A tristeza e a depressão têm uma similaridade sendo facilmente confundida uma com a outra. Sua distinção é baseada no exemplo de um óbito na família, após o luto a tristeza se abranda e há o recomeço, na depressão a tristeza aparece sem motivo aparente e persiste. Alguns sintomas mais comuns ás pessoas que acometem deste mal são; Distúrbios do sono caracterizado pela insônia ligada a pessoas deprimida. Distúrbios alimentares pessoas anoréxicas e que sofrem de bulimia com inapetência ou que tem apetite em excesso podem ser deprimidas. A melancolia chamada de maníaco depressivo por intercalarem euforia e tristeza, estes indivíduos sofrem por estarem sempre triste. Na autoflagelação o indivíduo poderá ter seu sistema imunológico alterado por infligir sofrimento a si próprio. (ABP, 2006, p.18).

Conwell (2015) cita que, a culpa é uma condição expressada também como sentimento, deve ser observada com cautela, considerando os paradigmas de cada cultura. Em muitas sociedades, os fatores de causalidade do suicídio podem ser atribuídos a um conjunto de causas externas. 
Faria (2014) enfatiza que, os fatores como os vínculos afetivos e outras circunstâncias na vida emocional, adotam um papel secundário, apenas associado como uma manifestação da causalidade não natural.

Raiva é uma etapa é um dos estados emocionais que podem ser considerados como uma meta que expressa de forma tumultuada no âmbito familiar, é um sintoma que indica quando a pessoa está saindo das profundezas da depressão. Os desejos agora estão sendo manifestados sem medo e já é uma manifestação saudável. A raiva é provocada e explica um conjunto de fatores que acontecem na mente: As pessoas sentem raiva por não interferir para evitar o suicídio, que é diferente do sentimento de culpa - que pode ser expressa como um sentimento autodestrutivo. (ABP, 2006, p.22).

Conforme Moura (2011) o processo e a capacidade de lidar com o problema, pode resultar em um desfecho favorável que compreende em:

Um aspecto que merece destaque, onde as pessoas que vivem e enfrentam o problema no seu dia a dia, e são elas que podem gerar ações concretas e efetivas de apoio para aqueles que estão em situação de vulnerabilidade. 0 profissional de saúde mental é a principal referência nas situações de sofrimento psíquico e, portanto, deve estar atento para o risco de suicídio. As informações podem ser obtidas através do próprio paciente ou de familiares e amigos. (p.45).

Moreira e Bastos (2015) ressaltam que, o luto por suicídio, por ser uma experiência dolorosa, difícil, traumática, cuja vivência se dá por intenso sofrimento psíquico, provoca, não raras vezes, adoecimentos físicos. Há pesquisadores que consideram que os sobreviventes ao suicídio, passam também pelo transtorno pós-traumático; eles vivenciam duas situações.

\section{PROCEDIMENTOS METODOLÓGICOS}

O presente projeto foi desenvolvido em forma de pesquisa bibliográfica sistemática, onde os dados e informações necessárias foram obtidos a partir do levantamento de autores especializados através de livros, artigos científicos TCCs, revistas especializadas, entre outras fontes. Uma pesquisa bibliográfica sistemática pode ser definida como aquela que "observa, registra, analisa e correlaciona fatos ou fenômenos (variáveis) sem manipulá-los". (JARDILINO; ROSSI; SANTOS, 2008).

Gil (2010, p.29) conceitua pesquisa bibliográfica da seguinte forma

A pesquisa bibliográfica é elaborada com base em material já publicado. Tradicionalmente, esta modalidade de pesquisa inclui material impresso, como livros, revistas, jornais, teses, dissertações e anais de eventos científicos. Todavia, em virtude da disseminação de novos formatos de informação, estas pesquisas passaram a incluir outros tipos de fontes, como discos, fitas magnéticas, CDs, bem como o material disponibilizado pela Internet.

A abordagem desta pesquisa é a qualitativa. A pesquisa qualitativa não se preocupa com representatividade numérica, mas, sim, com o aprofundamento da compreensão de um grupo social, de uma organização, entre outros. A abordagem qualitativa opõe-se ao pressuposto que defende um modelo único de pesquisa, o que pressupõe uma metodologia própria. Assim, os pesquisadores qualitativos, recusam o modelo positivista aplicado ao estudo da vida social. Preocupam-se, portanto, com aspectos da realidade que não podem ser quantificados, centrando-se na compreensão e explicação da dinâmica das relações sociais. Para Minayo (2001), a pesquisa do tipo qualitativa, trabalha com o universo de significados, motivos, aspirações, crenças, valores e atitudes, o que corresponde a um espaço mais profundo das relações, dos processos e dos fenômenos que não podem ser reduzidos à operacionalização de variáveis.

Os instrumentos utilizados para a realização da pesquisa foram o Google acadêmico, biblioteca virtual em saúde (BVS), Scientific Electronic Library Online SciELO. Estes são bancos de dados de cunho científico que apresentam a veracidade das informações, abalizando e referendando os aspectos sobre a temática, visando mostrar os fatores intrínsecos e desencadeadores do suicídio em adolescentes.

Através desses instrumentos foi feito a busca por artigos científicos, livros, monografias, TCCs, revistas especializadas entre outros. E a partir deles, foram feitas a coleta e seleção dos dados sobre o tema. 
Inicialmente foram utilizados como descritores, os seguintes termos relacionados ao suicídio: adolescência, ideação suicida, depressão, adolescente, transtornos psicológicos, sofrimentos psíquicos, fases suicidas, ansiedade, riscos, fatores e causas e prevenção ao suicídio.

Após a busca, foi realizada a leitura, a seleção e análise de informações referentes ao tema delimitado. Na sequência, foi feita a seleção dos artigos e livros de acordo com o ano de publicação, autores de áreas relacionadas, além dos periódicos que mais publicaram a respeito do tema. Posteriormente, as informações utilizadas na pesquisa foram selecionadas, possibilitando analisar intrinsecamente sobre o suicídio e os fatores de risco em adolescentes.

Em relação à ética, pode-se garantir que as autorias das informações contidas no trabalho foram preservadas por meio de referências e citações dos autores. Para a sua composição, este trabalho foi composto por 28 artigos em português, 3 em espanhol, 2 em inglês, 8 livros, 2 dissertações e 2 TCCs. Somando-se um total de 45 referências bibliográficas. Os critérios de inclusão foram artigos científicos, monografias, TCCs, revistas especializadas e livros em português, inglês e espanhol, publicados desde 2000, e que abordam o tema da referente pesquisa. Os critérios de exclusão foram artigos, livros, TCCs, monografias e revistas especializadas que não atenderam aos critérios citados a cima.

\section{RESULTADOS E DISCUSSÃO}

\section{Suicídio}

A referida pesquisa procura inicialmente através da ótica de alguns teóricos, conceituar suicídio e consequentemente o termo suicida. Na visão de Closs (2015) o suicídio é a morte por vontade e sem constrangimento, de si próprio. Cruz e Camargo (2017) apoiam esse pensamento quando afirmam que suicídio é o ato que consiste em por fim, intencionalmente, à própria vida.

Para Borges e Werlang (2006) a expressão suicida se refere aos pensamentos de auto destruição e ideias suicidas, englobando desejos, atitudes e planos que o indivíduo tem para dar fim à própria vida. Complementando essa conceituação Closs (2015) ressalta que suicida é todo aquele que deliberadamente consuma a própria morte.

Segundo Araújo, Vieira e Coutinho (2010) indivíduos que tem a intenção de acabar com a dor psíquica em algum momento em suas vidas, tiveram confusos em relação aos seus pensamentos, com o desejo de viver ou morrer, sendo assim, percebe-se que os problemas psíquicos podem levar o individuo a por fim em sua vida, não necessariamente por não desejar mais continuar a viver e sim para se livrar do sofrimento psíquico, onde na maioria das vezes o mesmo julga como sendo insuportáveis.

Com base no exposto, Moreira e Bastos (2015) destacam que, mesmo que esse fenômeno seja temido pela maioria das pessoas, o ato suicida deve-se ao fato de ser considerado como um alívio para aqueles que julgam não ter solução para seus problemas buscando por meio da morte, acabar com o seu sofrimento psíquico.

A respeito do referido fenômeno, constata-se que o aumento ao índice de suicídio é alarmante no mundo inteiro e por consequência disso, o suicídio é considerado como uma demanda complexa de saúde pública e que precisa e merece ser tratado com muita atenção e responsabilidade para que se possa dar apoio necessário às pessoas que se encontram em vulnerabilidade.

\section{Suicídio e suas fases na adolescência}

Para que se tenha um melhor entendimento sobre o suicídio na adolescência, se faz necessário entender primeiramente, sobre a adolescência, suas fases, bem como os processos de transformação e conflitos vivenciados pelo indivíduo característicos nesse período. Partindo desse princípio, Faria (2014) salienta que a etimologia da palavra adolescência remete à ideia de desenvolvimento, de preparação para o que está por vir, de mudança e de transformação.

A partir deste contexto, vale ressaltar que todos os seres vivos passam por várias fases e no que se refere aos seres vivos, sabe-se que normalmente humanos passam por quatro fases distintas que se inicia com a infância, posteriormente dar-se inicio ao processo da adolescência em seguida a fase adulta e por fim a velhice e cada uma dessas fases, possuem características peculiares de transformações, tanto ao que se refere as questões físicas, quanto as psicológicas bem como as sociais. 
No que se refere ao período exato que se compreende a adolescência percebe-se uma divergência. No Brasil o Estatuto da Criança (BRASIL [ECA], 1990), define o adolescente como o indivíduo entre 12 e 18 anos, por sua vez, a Organização Mundial da Saúde (World Health Organization - WHO, 2010), descreve esta etapa do ciclo vital, como, a transição entre a infância e a idade adulta e a define como o período entre 10 e 19 anos.

Ao que tange as transformações na adolescência, vale ressaltas que além das mudanças aparentes do corpo, ocorrido em virtude das alterações hormonais e a transição entre a infância e a fase adulta, ocorre também alterações bastante significativas cognitivas e sociais. Levando muitas vezes o adolescente a conflitos que resulte em ideações, manifestações e até mesmo a consumação do ato suicida.

Apoiando essas afirmações, Moreira e Bastos (2015) ressaltam que, o momento de passagem da infância para adolescência gera problemas existenciais, que podem levar os adolescentes a apresentarem pensamentos suicidas em baixa frequência e de forma esporádica.

Nas perspectivas voltadas ao suicídio, a cartilha de prevenção ao suicídio direcionada para conselheiros publicada em 2006 pela OMS, a adolescência é uma fase propensa aos pensamentos suicidas devido às mudanças que ocorrem durante a sua passagem. Mediante a análise de textos referentes à temática, entende-se, que no que se referem às questões emocionais, onde as mesmas se encontram confusas com ambivalência de sentimentos de amor e ódio dentro de um processo de identificação.

Todavia, vale ressaltar que dentre as transformações que o adolescente passa no decorrer de sua complexa transição destacadas pelos teóricos, uma das características da adolescência que merece ser destacada é a impulsividade.

Corroborando com o exposto, Daber e Baptista (2004) salientam que a impulsividade: é um momento transitório, que por alguns pontos negativos, criam ideia fixa constante no dia a dia, que podem ter duração de alguns minutos ou horas, que é gradualmente aumentada, resultando um impulso brusco e irreversível.

Faria (2014) enfatiza que a impulsividade merece destaque e atenção. Tais considerações são importantes, pois eventos conflitantes ou estressantes podem desencadear e resultar em eventos suicidas.

\subsection{Fatores relacionados ao suicídio em adolescentes}

Reconhecer os fatores relacionados a este evento se faz necessário tanto para familiares, amigos, quanto para os profissionais da área de saúde e em especial aos profissionais de saúde mental e para a sociedade como um todo. Pois na maioria das vezes a sociedade tem uma visão distorcida sobre a problemática e em virtude do não reconhecimento, aumenta desta forma, a resistência em dar o valor necessário que a situação exige. E esse reconhecimento é de extrema importância, pois poderá capacitar os mesmos para uma possível intervenção precoce resultando na diminuição do índice de suicídio.

Bertolote (2000) salienta que o suicídio é um problema complexo, pois não existe uma única causa ou uma única razão, resultando numa interação de fatores como: biológicos, genéticos, psicológicos, sociais, culturais e ambientais, ressaltando que tais fatores vivenciados de forma isolada, não são preditores de suicídio, mas suas consequências podem potencializar a vulnerabilidade ao comportamento suicida.

Em consonância com Bertolote, Moura (2004) salientam que o suicídio é um fenômeno complexo, que circunda diversos fatores e que atinge tanto as vítimas, quanto os que conseguem sobreviver de uma tentativa suicida. E dentre esses fatores pode-se destacar os transtornos mentais, principalmente a depressão como desencadeante de comportamentos suicidas. Pois a depressão é um distúrbio que prejudica a qualidade de vida das pessoas afetadas e consequentemente podendo ocasionar em suicídio.

Além disso, Meneghel et al, (2004) salientam que, levando em consideração as suas repercussões, a gravidez na adolescência é um fator de risco ao suicídio e que a ideação suicida está associada a depressão. Pois neste período ocorrem inúmeras mudanças orgânicas e psicológicas que ocorrem nesse processo, pois enfrentar uma gravidez indesejada na adolescência pode resultar em desespero, desamparo, desesperança, frustração, corroborando para a depressão, que é um distúrbio que prejudica a qualidade de vida das pessoas afetadas e consequentemente podendo ocasionar no suicídio.

Toro et al (2009) alegam que, fatores como, perdas recentes de um ente querido e tentativas prévias de suicídio, contribuem de forma significativa para o aumento de suicídio.

Bella, Fernández e Willington (2010) abordam as tentativas prévias de suicídio, como o fator de risco mais importante para predizer novos comportamentos suicidas em adolescentes. 
Mercy et al (2001) enfatizam que, o comportamento de imitação ou contágio, está relacionado ao conhecimento de uma pessoa que cometeu o suicídio e é um dos fatores que contribuem para o aumento de suicídio. Vale ressaltar que, o conhecimento de suicídio de pessoas famosas veiculados na mídia, pode contribuir para o comportamento de imitação.

Partindo do viés apresentado, nota-se uma convergência sobre esta temática por parte dos teóricos Daber e Baptista (2004), quando afirmam que várias pesquisas tem comprovado a existência do fenômeno suicídio, principalmente em adolescentes e adultos jovens, onde os mesmos são influenciados por divulgação de comportamento de pessoas que cometeram suicídio, ressaltando que pessoas com problema de saúde mental, estão mais vulneráveis a comportamentos de imitação.

Werlang, Borges e Fensterseifer (2005) em consonância com os autores supracitados, alegam que, segundo alguns estudiosos, o impacto que as notícias de suicídio veiculadas através da mídia, têm sido destacadas como sendo um importante fator de risco ao suicídio.

Desta forma, pode-se entender que, um comportamento de imitação é uma forma de aprendizagem observacional podendo ocorrer, por conhecer alguém que cometeu o suicídio, ou pela veiculação de notícias de pessoas famosas que cometeram o ato suicida. Percebe-se a importância desses casos não serem relatados de forma detalhada para que se minimize o comportamento de modelagem.

Em consonância com o exposto Araújo, Vieira e Coutinho (2010) enfatizam que indivíduos com histórico de suicídio na família, possuem maior risco para repetição do comportamento, verificando-se desta forma, a transgeracionalidade do comportamento suicida.

Conforme Braga (2011) a vulnerabilidade desencadeada pelas situações de pobreza, é uma situação social que pode contribuir para o comportamento suicida, visto que o desemprego, o estresse econômico e a instabilidade familiar aumentam o nível de ansiedade dos indivíduos. Sendo assim, destaca-se a importância de se entender dos efeitos que a pobreza pode ocasionar para a saúde mental e a maneira de superar tais desafios.

Segundo Bertolote (2000) a maioria dos suicídios pode ser evitada através de prevenção. E por se tratar de uma questão de saúde pública, uma das iniciativas que deve ser feita é a de capacitar equipe de atenção primária a saúda para que se possa identificar, abordar, manejar e encaminhar as pessoas que se encontram em sofrimento psíquico. Vale ressaltar que a atenção dos familiares e amigos às pessoas que se encontram em vulnerabilidade é fundamental.

Com base nas pesquisas realizadas, é notório que, o suicídio na adolescência é um fenômeno onde existem diversos eventos estressores que podem desencadear tanto a ideação suicida, quanto à tentativa e consequentemente ao suicídio de fato. Por estas razões é imprescindível a observação e a atenção a qualquer mudança de comportamento abrupto.

\section{Fatores sociodemográficos}

Os fatores sociodemográfico compreendem a idade, gênero, religião, espiritualidade; fatores da esfera suicida: história de tentativas de suicídio prévias: plano suicida e acesso a meios letais.

De acordo com Kuczynski (2014) o comportamento suicida na faixa etária dos 12 anos é menos frequente, já as ideações mórbidas, podem ocorrer com frequência com pensamentos disfuncionais.

Jucáa e Vorcarob (2018) destacam que a ocorrência de automutilação em jovens por não se sentirem pertencente a algum grupo social é um fator preocupante, pois com o passar dos anos, os mesmos podem adquirir formas mais eficazes para se tornar um potencial suicida e observa-se uma concretização desse comportamento suicida por volta dos 40 anos de idade, em virtude de fatores estressantes ou ambientais.

Conwell (2015) salienta que as mortes precoces desejadas por alguns idosos podem se confundidas com a intenção de suicídio, mas apesar de parecerem sinônimas, tem conotações diferentes podendo ter diagnósticos equivocados.

Percebe-se uma divergência de resultados ao que se refere a gênero, quando Godoy (2018) alega que as mulheres lideram o índice de ideação e de tentativas de suicídio, principalmente após a puberdade, com uma probabilidade dez vezes maior de realizar tentativas de suicídio. Pinto, Alves e Maia (2015) alegam que segundo as pesquisas às taxas de suicídio, o índice de suicídio é menor no gênero feminino do que a do gênero masculino na maioria dos países, tal como em Portugal, as taxas de suicídio dos indivíduos do 
gênero feminino são três vezes menores, entre 6 a 10 anos de idade, do que a do gênero masculino, com exceção da China.

E para explicar o alto índice de suicídio na China Daudt, Souza e Sperb (2007) enfatizam que os fatores no aumento do suicídio entre as mulheres chinesas podem estar relacionados com a disrupção e a marginalização da mulher, consequência da transição de uma sociedade tradicional agrária para uma sociedade capitalista e urbana.

No decorrer da pesquisa destacou-se dentre os fatores sóciodemográficos a letalidade. A letalidade referese ao potencial de perigo de morte associado ao método utilizado como a utilização de armas de fogo, a precipitação de alturas ou o enforcamento, métodos de alta letalidade. Diante disso, pode-se perceber que os indivíduos que tentam se suicidar com alta letalidade, em média encontra-se em risco elevado para cometer suicídio.

Mendonça (2015) ressalta que além da religião e espiritualidade, a raça e etnia são fatores importantes nesse processo, salientando que alguns estudos enfatizam que religião e a espiritualidade demonstram menor frequência de comportamento suicida, porém reforçam que a acessibilidade aos meios letais é um importante facilitador ao risco de suicídio, principalmente quando se refere aos adolescentes, pois deve-se levar em conta a impulsividade, característico da adolescência e por esta razão, atos suicidas em jovens, ocorrem de forma abrupta, contribuindo par o aumento do índice de suicídio.

Diante disto, Moura (2011) destaca a importante restringir o acesso a métodos altamente letais para prevenir o suicídio nos adolescentes e adultos jovens. Toda via há de se ressaltar que, a presença de armas de fogo em casa, e de outros meios letais (como medicamentos) e a supervisão parental inadequada aumentam o risco de suicídio. Segundo Conselho Federal de Psicologia (2013) diversos fatores protetores que são semelhantes aos da população em geral, porém com mais relevantes para os adolescentes são fatores familiares, individuais e sociais.

\section{Fatores culturais}

Para Closs (2015) na relação entre fatores culturais e o fenômeno suicídio, esses fatores mobilizam as emoções coletivas de uma sociedade adquirindo também uma dimensão política, ideológica e social em torno da perspectiva de vida, levando em consideração que diversos fatores ao que tange a esse contexto, impedem que essa perspectiva seja desenvolvida de forma efetiva.

Segundo Mendonça (2015) a expressão de mal-estar social é responsável pelo alto índice de suicídio nas populações indígenas no Brasil em especial na etnia Guarani Kaiowá, mas destaca que esse fenômeno ocorre em diversos setores sociais.

Por sua vez, Cruz e Camargo (2017) enfatiza que os profissionais de condutas suicidas acreditam que o conjunto de emoções que ocorre na historia de vida pessoal e coletiva da população é um bem imprescindível.

\section{Fatores psicológicos}

O suicídio acontece em decorrência de fatores multifacetados e os de ordem psíquica são bastante significativos, por esta razão, mesmo que os transtornos não tenham sido diagnosticados por um profissional, a atenção de familiares e amigos é imprescindível para que se tente evitar um possível suicídio. Moura (2011) enfatiza que determinadas concepções costumam culpabilizar as pessoas em torno do suicida, o estigmatizam, constrangendo-os na maioria dos casos.

Segundo Berti (2010) muitas vezes os progenitores se tornam negligentes frente ao sofrimento psíquico do filho quando os mesmos acreditam que cumprindo as necessidades básicas, como casa, alimentação e cuidados físicos são suficientes e geralmente não dão o devido valor às necessidades psicológicas e emocionais. Desta forma, entende-se a importância dos progenitores, estarem próximos aos filhos e que além dos cuidados básicos, tenha disponibilidade para uma escuta sem julgamento, tentando entender a emoção que o filho traz em cada frase verbalizada, fazendo com que o mesmo se sinta acolhido e seguro em expressar o que sente e o que pensa diante de seu sofrimento psíquico, vale ressaltar a importância de que a buscar ajuda de profissional para lhe auxiliar nesse processo quando julgar necessário. 
Para Borges, Werlang e Copatti (2008) a probabilidade de adolescentes ficarem deprimidos ou com comportamentos suicidas é aumentada quando os mesmos passam por abuso na infância e em especial ao abuso sexual, emocional e maus tratos.

Os argumentos apresentados por Borges, Werlang e Copatti (2008) convergem com os argumentos de Dutra (2002), quando enfatizam, que uma história de tentativa de suicídio na adolescência, bem como de suicídio, pode estar associada tanto a maus tratos, como abuso físico e sexual. E Pinto, Alves e Maia (2015) apoiam essa ideia quando dizem que o abuso físico e emocional, os maus tratos que inclui o abuso sexual, físico, emocional e a negligência estão associados independentemente com a ideação suicida e com as tentativas de suicídio.

Em relação ao bullyng, pode-se afirmar que as pessoas que passam por esta experiência podem ser agredidas tanto de forma individual quanto grupal, ressaltando que essas agressões podem ser de forma verbal, física e psicológica. Coutinho, Araújo e Vieira (2010) destacam que bullying é um tipo de violência exercida entre pares, em contexto escolar, ou mesmo nos arredores da escola e vizinhança e que esse termo está relacionado à agressividade e vitimização e desigualdade de poder, de forma intencional, recorrente e sem razão que justifique tal ato.

Para Conwell (2015) dentre tantos abusos que o ser humano pode sofrer, o abuso emocional é algo mais difícil de categorizar, por ser subjetivo incluído desde insultos verbais ao bem-estar ou à autoestima, ou até mesmo a qualquer ameaça ou humilhação, entre outros.

Percebe-se que dentre os vários fatores que podem desencadear o suicídio, os fatores psicológicos estão em bastante evidência. Desta forma é de extrema importância melhor entendimento sobre esta questão, para que se possa ter uma visão mais ampliada sobre esta temática e para que se possa agir de forma mais assertiva, empática e sem julgamento, no momento em que seja necessário dar atenção às pessoas com tais vulnerabilidades, com o intuito de minimizar ou impedir o suicídio.

\section{Fatores psicopatológicos}

Existem diversos fatores psicopatológicos que podem desencadear o suicídio como depressão, alcoolismo dependência de drogas, distúrbios da personalidade entre outros.

Tavares (2005), Bertolote (2000) reforça que os comportamentos suicidas, estão menos associados com os eventos de vida e mais com a percepção dos eventos como negativos, sintomas afetivos e o número de internação psiquiátrica de indivíduo com esquizofrenia.

A partir desta compreensão, Conwell (2015) complementa que há outros fatores de risco como: idades mais jovens, a proximidade com o início da doença, a idade avançada no início da doença, o gênero masculino, quando faz uso abusivo de substâncias e o período durante e após um internamento psiquiátrico, além da má adesão ao tratamento.

Dutra (2002) ressalta que a dependência de álcool tem sido bastante discutida por ser considerada uma das maiores causas de tentativa de suicídio e que segundo as pesquisas o alcoolismo está presente em $85 \%$ das mortes por suicídio para cada 100 notificações, e associada com a depressão forma uma combinação fatal. Ter conhecimento de sobre estas questões, possibilita entender a gravidade deste fenômeno.

Segundo Beti (2010) o álcool enfraquece mecanismos de controle da mente, causando o rebaixamento da autoestima, tornando o indivíduo mais suscetível ao suicídio, enfatizando que o consumo de substâncias ilícitas impulsiona o mercado da interação social, onde a dependência química e o consumo de bebida alcoólica produzem reflexos negativos e que em virtude de aliviar o seu sofrimento e o sofrimento que causa em sua família sentem desejo de por fim a própria vida. Ainda discutindo sobre este assunto, o alcoolista adquire um quadro depressivo em $70 \%$ dos casos e $15 \%$ daqueles que estão inseridos em hospitais atentam contra a própria vida.

Em consonância com Beti, Moreira (2011) enfatiza que, tanto alcoólicos quanto dependentes de drogas ilícitas, se sentem inseguros por não satisfazer as expectativas dos pais, por sua vez, cometem suicídio com o intuito de não mais preocupar seus familiares.

Faria (2014) aborda que este assunto é complexo e o seu tratamento tem o mesmo teor de complexidade. Mas infelizmente a negligência tem uma grande responsabilidade no aumento e na dependência do consumo de substâncias entorpecentes. Não se pode negar o quanto este assunto merece importância, por se tratar de problemas de ordem pública e que ainda encontram-se dificuldades em realizar 
acompanhamento no tratamento de forma adequada, bem como a forma de lidar com a problemática, para que se possa conseguir diminuição do índice de suicídio.

Também é destacado como problema de saúde pública o transtorno bipolar e Mercy, et al(2001) destacam que este transtorno tem uma categoria de perturbações ao longo do tempo um ou mais episódios recorrentes de mania, hipomania ou depressão e que os fatores de risco de suicídio nas perturbações bipolares podem ser categorizados em quatro grupos: demográficos, clínicos e psicológicos e familiares/sociais, reforçando que geralmente primeira tentativa de suicídio ocorre de forma prematuramente, relativamente aos indivíduos que têm uma perturbação depressiva major.

Daudt, Souza e Sperb (2007) complementam que o gênero feminino está mais propício a risco de suicídio nestes indivíduos onde os comportamentos suicidas estão mais associados com a mania, do que com episódios de depressão e hipomania. E enfatiza que o sintoma psicótico tem um risco de ideação suicida e planejamento suicida elevados em jovens com perturbação bipolar sem sintomas psicóticos.

Segundo Moreira e Bastos (2015) os indivíduos com PHDA, possuem mais risco para comorbilidades psiquiátricas associadas. Salientado que os sintomas da PHDA foram associados com perturbações de ansiedade, alterações de humor e perturbações de comportamento em crianças e que em adolescentes foram associadas mais a perturbações de tiques, abuso de substância e dependência.

Segundo Moreira e Bastos (2015) as perturbações alimentares como anorexia nervosa e bulimia nervosa, contribuem para o risco de suicídio, mas ressalta que na atualidade houve um decréscimo referente a essa questão apesar de ainda continuar com taxas de suicídio superiores às da população em geral. $E$ que esse decréscimo ocorreu em virtude da redução de estigma contra o tratamento e melhor atenção aos casos, que por sua vez, necessitavam de tratamento na sequência da melhoria dos critérios de diagnóstico.

\section{Ideação e comportamentos suicidas na adolescência}

A palavra ideação remete ao seu significado, que é ideia, pensamento. E quando nos referimos à ideação suicida, trata-se de pensamentos ou planos que um indivíduo tem com objetivo de atentar contra a sua própria vida.

De acordo com Araújo, Vieira e Coutinho (2010), o suicídio corresponde ao desejo consciente de por fim a própria vida, tendo a clara noção do que o ato executado pode gerar. Mas vale ressaltar que nem todas as pessoas que tem ideação suicida têm comportamentos ou consumam o ato, mas é de extrema importância que se dê atenção aos que expressam esse desejo de se suicidar.

Werlang, Borges e Fensterseifer (2005) reafirmam que ideação suicida é um importante preditor de risco para o suicídio, sendo considerado o primeiro passo para sua efetivação. Entende-se dessa forma que em geral, quando o indivíduo comete o suicídio, o mesmo não o cometeu de forma abrupta, geralmente teve uma ideação, a tentativa até concretizar o seu desejo inicial.

Segundo os pioneiros na pesquisa sobre suicídio, Werlang, Borges e Fensterseifer (2005) independente da gravidade da tentativa, todo o ato que seja para atentar contra a própria vida deve ser considerado uma ação suicida e uma ação suicida, que pode ser: ideação suicida, tentativa de suicídio e a consumação do ato, quando a tentativa é fatal.

Braga (2011) enfatiza que a probabilidade na repetição do ato, após uma primeira tentativa de suicídio é alta. Portanto, o espaço de tempo entre: ideação suicida, tentativas e concretização da morte pode oferecer um tempo propício para que ocorra uma intervenção.

Segundo Bastos e Moreira (2015) na maioria das vezes os adolescentes têm atitudes que demonstram força, arrogância confronto e poder, mas na realidade, escondem em si, um pedido de atenção, de carinho, de limite e de proteção.

Conforme Moura (2011) a capacidade de lidar com essa problemática, poderá resultar em um desfecho favorável para aqueles que estão em situação de vulnerabilidade. Desta forma, levando-se em consideração a situação de vulnerabilidade que muitos adolescentes e jovens se encontram em relação a este fenômeno, faz-se necessário que, tanto os familiares, quanto a sociedade, a saúde pública, as escolas bem como os profissionais de saúde mental, tenham bastante conhecimento, para que possam lidar da melhor forma possível com esta problemática. 


\section{O sofrimento psíquico nas manifestações suicidas em adolescentes}

Segundo Moreira e Bastos (2015) após o choque, é possível que se observe alguns sinais físicos como: aperto na garganta, mal-estar estomacal, diarreia, respiração ofegante. É imprescindível a atenção vigilante aos sinais para que se possa dar o apoio no momento que se fizer necessário.

Prieto e Tavares (2005) ressaltam que mesmo que o sentimento comum seja o alívio, esse estado também pode ser seguido de um estado de choque.

Complementando, Braga (2011) enfatiza que após o estado de choque pode ocorrer à catarse neste momento e que as emoções são expressas em alguns casos, de maneira incontrolável, comumente visto em funeral. Destaca também que a catarse pode ser repressiva e angustiante, podendo ocorrer em algum momento, contribuindo para a aceitação dos fatos, ajudando a encontrar resposta para seus questionamentos.

Faria (2014) salienta que a depressão geralmente acontece após a descarga emocional, ressalta que a depressão reativa é variável e depende da experiência de vida de cada individuo e que o período depressivo é subjetivo. Desta forma entende-se que não existe um tempo determinado para o seu termino e que esse tempo se estende para quem se isola.

Para uma melhor compreensão Ribeiro (2003) destaca que, esse estado deve ser entendido como uma injúria emocional e que para sua superação seja efetiva, se faz necessário ajuda externa. E essa intervenção deve procurar evitar que se instale um quadro crônico para prevenir e impedir diversos comportamentos derivados desse processo.

Moreira e Bastos (2015) destacam que o luto por suicídio é uma experiência dolorosa, traumática e difícil de lidar, podendo provocar sofrimento psíquico. Desta forma, percebe-se que não existe uma elaboração prévia quando se perde um ente querido e quando a morte é em decorrência de suicídio o sofrimento poderá ser ainda mais intenso, vir acompanhado de sentimento de culpa, corroborando para o desencadeamento de vários transtornos.

Através das pesquisas realizadas, pôde-se ter um melhor entendimento e ampliação do conhecimento concernente ao suicídio na adolescência. Salientando que, compreender os processos que ocorrem neste fenômeno é de extrema importância para que se possa dar melhor suporte para os indivíduos em que se encontram em situação de vulnerabilidade.

\section{CONSIDERAÇÕES FINAIS}

Este trabalho foi de extrema importância para melhor compreensão sobre este fenômeno, ressaltando que o mesmo já se tornou problema de saúde pública, em virtude dos elevados índices de suicídio mundialmente e especialmente em adolescentes.

0 acesso à temática é vasto, pois na atualidade o tema vem tendo bastante destaque, principalmente na mídia e as campanhas contra o suicídio, tem se intensificado significativamente, demonstrando a preocupação das pessoas em relação à problemática. Desta forma, torna-se de extrema importância que se dê atenção a este fenômeno, pois trata-se de um problema complexo, onde não existe uma causa única e sim uma junção de fatores que podem desencadear a ideação suicida, bem como a consumação do ato.

Os fatores de risco em adolescentes variam desde as mudanças biológicas, sociais, drogas lícitas e ilícitas, eventos estressores, problemas emocionais, violência como bullying, questões de gênero, transtornos mentais entre outros.

Através das pesquisas percebeu-se que o suicídio na adolescência trata-se de um fenômeno além de complexo, multideterminado e de ordem biológica, psicológica, cultural e sociodemográfica. Ressaltando que grande parte dos adolescentes que se suicidam tem transtornos mentais, onde na maioria dos casos, sintomas e sinais não são percebidos por familiares, amigos e muitos não são diagnosticados por não ter conseguido chegar a ter um atendimento de saúde.

Neste sentido, é perceptível a importância e a necessidade de capacitação tanto dos familiares, educadores, quanto dos profissionais da área da saúde e em especial aos profissionais de saúde mental, para que os mesmos possam ter manejo para identificarem os riscos e darem apoio aos que se encontram em situação de vulnerabilidade, pois geralmente quem pretende atentar contra a própria vida, normalmente demonstrará sinais de alerta e sintomas, destacando que, quando um indivíduo chega a ter 
ideação ou até mesmo a cometer o ato, ele não está querendo se matar e sim, livrar-se da dor e de todo o sofrimento em que está vivenciando.

Mas vale ressaltar que somente saber reconhecer os fatores de risco, não é suficiente para evitar o suicídio, faz necessário que se tenha o conhecimento dos meios de proteção contra o suicídio, para que se possa conseguir criar estratégia de prevenção, como rede de apoio tanto das escolas, como dentro do meio familiar e também ter acesso aos lugares que fazem atendimentos psicológicos e psiquiátricos voltados para esta temática e em especial.

A família tem um papel primordial e vital dentro deste contexto e principalmente ao que se refere a pai e mãe de filhos adolescentes, onde os mesmos tem uma tarefa a mais, tornando-se importe que observem os seus filhos, sendo mais participativos em suas atividades diárias, procurando fazer sempre que possível uma escuta sem julgamentos, sem estigmas, procurando entender a emoção de cada situação verbalizada e levando sempre em consideração qualquer sinal de ideação suicida, pois propiciar condições para que o adolescente verbalize o que está sentindo poderá fazer com que o mesmo além de ter uma catarse, entenda que existe solução para os seus problemas de forma saudável.

Através das pesquisas, percebeu-se que o suicídio, em especial na adolescência, é um fenômeno que vem tomando uma grande proporção na atualidade. Logo, se torna imprescindível que se tenha melhor entendimento sobre esta problemática, levando em consideração a importância de se compreender como se dá esse processo na vida do adolescente, analisando as suas fases, os principais fatores que corroboram para a efetivação deste evento, examinando desde a ideação, às manifestações que o individuo apresenta, para que se possa evitar a consumação do ato. Pois ter o conhecimento e a compreensão desde fenômeno, poderá contribuir para uma observação mais apurada e atitudes mais assertiva em especial por parte dos familiares, amigos, educadores e profissionais de saúde mental e da sociedade como um todo, contribuindo de forma significativa para que o índice de suicídio que temos na atualidade seja minimizado.

\section{REFERÊNCIAS}

[1] ARAUJO, Luciene da Costa; VIEIRA, Kay Francis Leal; COUTINHO, Maria daPenha de Lima. Ideação suicida na adolescência: um enfoque psicossociológico no contexto do ensino médio. Psico-USF (Impr.), Itatiba $\quad$ v. 15, n. 1, p. 47-57, Apr. 2010. Disponível em <http://www.scielo.br/scielo.php?script=sci_arttext\&pid=S1413-

82712010000100006\&lng=en\&nrm=iso>. Acesso em 22 Set. 2020. https://doi.org/10.1590/S141382712010000100006

[2] ASSIS, SIMONE. AVANCI, JOVIANA. OLIVEIRA, RAQUEL. Violência escolar e autoestima de adolescentes. Cadernos de Pesquisa, v. 36, n. 127, p. 35-50, jan./abr. 2006. Disponível em: http://www.scielo.br/pdf/cp/v36n127/a0336127.pdf. Acesso em: 21 abr. 2015.

[3] ASSOCIAÇÃO BRASILEIRA DE PSIQUIATRIA (ABP). Depressão, o mal do século. Rio de Janeiro (RJ): ABP, 2006. Disponível em: <http://abp.org.br/portal/clippingsis/exibClipping/?clipping=3343>. Acesso em: 02 nov. 2019.

[4] BAHLS, S. C. "Aspectos clínicos da depressão em crianças e adolescentes: características clínicas”. Jornal de Pediatria, vol. 78, n. 5, 2002.

[5] BAHLS, Saint-Clair; BAHLS, Flávia Rocha Campos. Depressão na adolescência: características clínicas. Interação em Psicologia, Curitiba, june 2002. ISSN 1981-8076. Disponível em: <https://revistas.ufpr.br/psicologia/article/view/3193>. Acesso $\quad$ em: 22 nov. 2019. doi:http://dx.doi.org/10.5380/psi.v6i1.3193.

[6] BAPTISTA, M. N. Suicídio: Aspectos teóricos e pesquisas internacionais. In: M.N. BAPTISTA (Ed.), Suicídio e depressão - atualizações. Rio de Janeiro (RJ): Guanabara Koogan, 2004.

[7] BELLA, M. E.; FERNÁNDEZ, R.; WILLINGTON, J. M. Intento de suicidioenniños y adolescentes: Depressión y transtorno de conductadisocial como patologías más frecuentes. Buenos Aires: Archivos Argentinos de Pediatria, 2010.

[8] BERTI, Fernanda Guerra. Suicídio na Adolescência: Revisão Bibliográfica. Secretária de Estado da Saúde. Programa de Aprimoramento Profissional. Trabalho de Conclusão de Curso. Marília (SP): Faculdade de Medicina Marília, 2010. Disponível em: <http://ses.sp.bvs.br/lildbi/docsonline/get.php?id=1531>. Acesso em: 2Nov 2019. 
[9] BERTOLOTE, J. M (coord.). Transtornos Mentais e Comportamentais: departamento de saúde mental organização mundial da saúde. Rio de Janeiro (RJ): Genebra, 2000.

[10] BORGES, V. R.; WERLANG, B. G. Estudo de ideação suicida em adolescentes de 13 a 19 anos. Psicologia, Saúde \& Doenças, Lisboa, v. 7, p. 195-209, 2006.

[11] BORGES, V. R.; WERLANG, B. S. G. Estudo de ideação suicida em adolescentes de 15 a 19 anos. Estudos de Psicologia, v. 11, n. 3, p. 345-351, 2006.

[12] BORGES, V. R.: WERLANG, B. S. G.: COPATTI, M. Ideação suicida em adolescentes de 13 a 17 anos. São Paulo (SP): Barbarói, 2008.

[13] BOTEGA, N. J. Suicídio e tentativa de suicídio. In: LAFER, B. et al. (Ed.). Depressão no ciclo da vida. Porto Alegre (PR): Artmed, cap. 16, p. 157-165, 2000.

[14] BRAGA, Luiza de Lima. Exposição à Violência e Comportamento Suicida em Adolescentes de Diferentes Contextos. Rio Grande do Sul (RS): UFRGS, 2011. Dissertação. Rio Grande do Sul: Universidade Federal do Rio Grande do Sul, Instituto de Psicologia. Disponível em: <https://lume.ufrgs.br/bitstream/handle/10183/49283/000836293.pdf?sequence=1\&isAll owed=y>. Acesso em: 02 Nov 2019.

[15] CLOSS, Cristiane CledirWeizenmann. Suicídio como Sintoma Social: Questões Sócio-Culturais e Psicológicas envolvidas e a Intervenção da Psicologia. Trabalho de Conclusão de Curso. Santa Rosa (RS): Universidade Regional do Noroeste do Estado do Rio Grande do Sul. Rio Grande do Sul (RS): URN, 2015. Disponível em: <http://bibliodigital.unijui.edu.br:8080/xmlui/bitstream/handle/123456789/3301/TCC\%20 Cristiane\%20Closs\%20p\%20dia\%2004.pdf?sequence=1>. Acesso em: 02 nov 2019.

[16] CONSELHO FEDERAL DE PSICOLOGIA. O Suicídio e os Desafios para a Psicologia / Conselho Federal de Psicologia. Brasília (DF): CFP, 2013.

[17] CONWELL, Yeates. Desafios para a prevenção de suicídios na idade avançada. Rio de Janeiro (RJ): Scielo [online], jun., 2015. Disponível em: <http://www.scielo.br/pdf/csc/v20n6/1413-8123-csc-20-061652.pdf>. Acesso em: 10 out 2016.

[18] CHAPliN, T. M.; Hansen, A.; Simmons, J.; Mayes, L. C.; Hommer, R. E.; Crowley, M. J. (2014). Parental-adolescent drug use discussions: Physiological responses and associated outcomes. Journal of Adolescent Health, 55(6), 730-735. https://doi.org/10.1016/j.jadohealth.2014.05.001

[19] CRUZ Mayara Peres da; CAMARGO, Nayara Santos. Suicídio - "Interfaces De Um Problema De Saúde Pública". Lins (SP): Unisalesiano, 2017. Disponível em: <http://www.unisalesiano.edu.br/biblioteca/monografias/61000.pdf>. Acesso em: 02 nov 2019.

[20] DABER, A. V. S.; BAPTISTA, M. N. Suicídio e saúde mental na mídia. In: M. N. BAPTISTA (Ed.), Suicídio e depressão - atualizações. Rio de Janeiro (RJ): Guanabara Koogan, 2004.

[21] DAUDT, P.; SOUZA, L.; SPERB, T. Amizade e gênero nos conflitos de préescolares. Rio de Janeiro (RJ): Interpersona, 2007.

[22] DOS SANTOS, Gerson Tenório; ROSSI, Gisele; JARDILINO, José Rubens L. Orientações metodológicas para elaboração de trabalhos acadêmicos..São Paulo (SP): Gion, 2000.

[23] DUTRA, E. Comportamentos autodestrutivos em crianças e adolescentes: Orientações que podem ajudar a identificar e prevenir. In: C. S. HUTZ (Ed.), Situações de risco e vulnerabilidade na infância e adolescência: Aspectos teóricos e estratégias de intervenção. Porto Alegre (PR): Casa do Psicólogo, 2002.

[24] FARIA, Ana Cristina Gomes Marques de. Suicídio na Suicídio. Pró-Reitoria de PósGraduação e Pesquisa. Programa de Pós-Graduação Stricto Senso em Psicologia. Dissertação. Goiânia (GO): Pontifícia Universidade Católica de Goiás, $2014 . \quad$ Disponível <http://tede2.pucgoias.edu.br:8080/bitstream/tede/1831/1/ANA\%20CRISTINA\%20GOM ES\%20MARQUES\%20DE\%20FARIA.pdf>. Acesso em: 02 nov 2019.

[25] FREITAS, G. V. S. BOTEGA, N. J. Gravidez na adolescência: Prevalência de depressão, ansiedade e ideação suicida. São Paulo (SP): Revista da Associação de Médica Brasileira,n.3, v.48 2002.

[26] GIL, Antônio Carlos. Como Elaborar Projetos de Pesquisa. 5. ed. São Paulo: Atlas, 2010. 
[27] GODOY, Victor Polignano. Suicídio: compreender, identificar e intervir. São Paulo (SP): Sociedade Brasileira de Neuropsicologia(SBNp), 2018. Disponível em: <http://www.hu.usp.br/wp-content/uploads/sites/406/2018/07/Cartilhasuic\%C3\%ADdio_final.pdf>. Acesso em: 02 Nov 2019.

[28] JUCÁA, Vládia dos Santos; VORCAROB, Angela Maria Resende. Adolescência em atos e adolescentes em ato na clínica psicanalítica. Artigo. Salvador (BA): Universidade Federal da Bahia, v.29, n. 2, p.246-252, 2018.

[29] KINYANDA, E.; KIZZA, R.; LEVIN, J.; NDYANABANGI, S.; ABBO, C. Adolescentsuicidality as seen in rural northeastern Uganda. Crisis, 2011. Disponível em: . Acesso em: 05 jul 2019.

[30] KRÜGER, L. L.; WERLANG, B. S. G. A dinâmica familiar no contexto da crise suicida. Rio de Janeiro (RJ): Psico-USF, 2010.

[31] KUCZYNSKI, Evelyn. Suicídio na infância e adolescência. São Paulo: USP, Psicologia USP, v. 25, n. 3, p.4246-252.

[32] MENDONÇA, Flávio Valério Moniz. Suicídio na Adolescência. Coimbra (PT): Faculdade de Medicina da Universidade de Coimbra, 2015. Dissertação.

[33] MENEGHEL, S.N.; VICTORA, C. G.; FARIA, N. M. X.; CARVALHO, L. A.; FALK, J. W. Características epidemiológicas do suicídio no Rio Grande do Sul. Rio Grande do Sul (RS): Revista de Saúde Pública, v.6 n.38, p.804-810, 2004.

[34] MERCY, J. A.; KRESNOW, M.; O'CARROLL, P.; LEE, R.; POWELL, K.; POTTER, L.; SWANN, A.; FRANKOWSKI, R.; BAYER, $\quad$ T. Is suicide contagious? A studyoftherelationbetweenexposuretothesuicidalbehaviorofothersandnearlylethal suicide attempts. New York: American JournalofEpidemiology, 2001.

[35] MINAYO, M. C. S. (Org.). Pesquisa social: teoria, método e criatividade. Petrópolis (RJ): Vozes, 2001.

[36] MOREIRA, L. C. O. BASTOS, P. R. H. O. Prevalência e fatores associados à ideação suicida na adolescência: revisão de literatura. Psicologia Escolar e Educacional, v. 19, n. 3, p. 445-453, 2015.

[37] MOREIRA, Lenice Carrilho de Oliveira; BASTOS, Paulo Roberto Haidamus de Oliveira. Prevalência e fatores associados à ideação suicida na adolescência: revisão de literatura. São Paulo: Revista Quadrimestral da Associação Brasileira de Psicologia Escolar e Educacional, SP, v.19, n.3, p.445-453, 2015.

[38] MOURA, Anna Tereza Miranda Soares de (coord.). Prevenção do suicídio no nível 27 local: orientações para a formação de redes municipais de prevenção e controle do suicídio e para os profissionais que a integram. Porto Alegre (PR): CORAG, 2011.

[39] ORGANIZAÇÃO MUNDIAL DA SAÚDE (OMS). Prevenção do suicídio um recurso para conselheiros. Genebra: OMS, 2006.

[40] PINTO, Vanessa Cristina Pires; ALVES, Joana Ferreira Cardoso; MAIA, Ângela Costa. Adversidade na infância prediz sintomas depressivos e tentativas de suicídio em mulheres adultas portuguesas. Campinas (SP): Estudos de Psicologia, v.32, n.4, p. 617-625, 2015.

[41] PRIETO, D; TAVARES, M. Fatores de risco para suicídio e tentativa de suicídio: Incidência, eventos estressores e transtornos mentais. Rio de Janeiro (RJ): Jornal Brasileiro de Psiquiatria, v.54 n.2, p.146-154, 2005.

[42] RIBEIRO, Daniel Mendelski. Suicídio: critérios científicos e legais de análise. Santa Catarina (SC): Verbo Jurídico, nov., 2003.

[43] ROSKOSZ, Flávia Laís Souza; CHAVES, Simone Küller; SOCZEK, Kelly de Lara. Suicídio na adolescência e terapia cognitivo-comportamental. Ponta Grossa (PR): Faculdade Sant'Ana, 2017.

[44] TORO, D. C.; PANIAGUA, R. E.; GONZÁLEZ, C. M.; MONTOYA, B. Caracterización de adolescentes escolarizados conriesgo de suicídio. Medellín: Revista da Facultad Nacional de Salud Pública, v.27, n.3, p.302-308, 2009.

[45] WERLANG, B. S. G.; BORGES, V. R.; FENSTERSEIFER, L. Fatores de risco ou proteção para a presença de ideação suicida na adolescência. Revista Interamericana de Psicologia, 2005. 


\section{Capítulo 4}

As causas que levam a depressão em idosos que são abandonados pela família em instituições de longa permanência

\section{Brenda Stefany Pereira}

Resumo: Esta pesquisa visa abordar as causas que levam a depressão em idosos institucionalizados visto que a causa da depressão neste trabalho é delimitado como uma consequência do abandono do idoso em asilos, ou como podemos chamar de instituições de longa permanência. 0 objetivo geral do trabalho é discutir a relação do abandono familiar e o desencadeamento da depressão em idosos. Estas instituições são vistas como casas de longa permanência aos idosos que carecem de cuidados e assistências devidas, porém quando deixados aos cuidados de outras pessoas que são desconhecidas tem como consequência ficarem suscetíveis e serem acometidos pela depressão. 0 tipo de pesquisa utilizada é a pesquisa bibliográfica qualitativa sistemática, tendo como utilização os devidos instrumentos que abrangem dados cofiáveis de cunho cientifico que permitem coletas de informações. A depressão é um tema importante, porque revela as doenças ou antipatias psicológicas das pessoas em detrimento de uma causa muito marcante. A ligação de causa e consequência que acarretam a depressão nos idosos institucionalizados são intrinsecamente ligadas, buscando-se assim entender sobre a temática com domínio e seriedade para que os leitores compreendam a importância deste projeto, pois uma vida mais saudável e expectativa de longevidade maior é o que se espera para a população idosa.

Palavras-chave: Depressão; Idoso; Instituições de longa permanência. 


\section{INTRODUÇÃO}

As instituições de longa permanência são locais que acolhem os idosos em regime integral em situação de abandono ou negligência, existem casos de suspensão temporária ou quebra de vínculo com os familiares. O índice de idosos abandonados pela família em ILPI vem crescendo cada vez mais, ocasionando no idoso algum tipo de sofrimento psíquico, pois a maioria sente-se desvalorizado nessas condições. 0 idoso institucionalizado vive uma realidade totalmente diferente da qual está habituado, pois o mesmo passa conviver com outras pessoas as quais são desconhecidas, além de gerar o sentimento de inutilidade e diante disto ocorre o desencadeamento da depressão.

A depressão é um problema frequente na sociedade e pode ser entendida enquanto sintoma no qual pode surgir nos mais variados quadros clínicos ou enquanto síndrome incluindo não apenas alterações do humor, mas também uma gama de outros aspectos, incluindo alterações cognitivas, psicomotoras. As taxas de prevalência da depressão nos idosos são três a cinco vezes maiores, sendo que na maior parte das vezes, a depressão é frequentemente não diagnosticada em idosos que se encontram institucionalizados (BROWN, LAPANE; LUISI, 2002).

As causas que levam a depressão em idosos são as mais diversas, contudo o estudo abordado neste trabalho é voltado para o desenvolvimento de pesquisa em instituições de longa permanência, como na maioria dos casos estudados, é o maior motivo da depressão cumulado com outra variável muito relevante que é o abandono pelos familiares.

0 presente trabalho visa abordar uma temática de extrema relevância para sociedade, pois o idoso foi quem proporcionou grande contribuição para o meio qual vivemos hoje, por isso, nada mais justo do que entender o porquê, como, quais as causas, consequências e pensamentos que levam os familiares e parentes próximos a abandonarem nosso anciões em instituições, e como consequência a ligação desses atos com a depressão do idoso.

Posteriormente aspectos importantes serão enfatizados quanto ao tema abordado que são as causas que levam a depressão em idosos, tendo em vista que a delimitação ocorre em idosos que são abandonados pela família em instituições de longa permanência, abrangendo o problema: quais são as causas que levam a depressão em idosos que se encontram institucionalizada. Para alcançar o objetivo geral cujo é discutir a relação do abandono familiar e o desencadeamento da depressão em idosos, foram estabelecidos como objetivos específicos: a) Apresentar o processo de envelhecimento e suas consequências biopsicossociais. b) Levantar a questão do abandono de idosos em instituições de longa permanência e as consequências causadas por esse abandono. c) Descrever o desencadeamento da depressão nos casos de abandono de idosos em instituições de longa permanência. d) Abordar os fatores que contribuem para a prevenção da depressão em idosos institucionalizados.

0 interesse pela pesquisa deu-se pelo o fato de querer levar a compreensão sobre a depressão acometida aos idosos que sofrem abandono familiar em instituições de longa permanência. Quando tratado esse tipo de problemática fica-se claro quanto o idoso necessita do amparo de seus familiares, pois o distanciamento físico e afetivo afeta diretamente a saúde psicológica do idoso diante ao meio que está inserido.

Ao abordar esse tema é possível trazer conscientização tanto para a família quanto para sociedade que o idoso precisa do acolhimento e cuidados necessários para ter uma boa qualidade de vida. Apesar de existirem diversos fatores que desencadeiam a depressão, o que chama atenção para que o assunto seja explanado é como os idosos institucionalizados estão mais suscetíveis em desenvolver quadros depressivos. É de extrema importância os familiares terem um elo significativo com idoso, pois isso que trará a melhoria e o bem-estar sem possíveis danos psíquicos. Uma vez o idoso encontrando-se em estado depressivo ele perderá a ânsia de viver e com ele todo um legado construído será deixado para trás.

Para a ciência é importante que ocorra a investigação e explicação dos fatos apontados, visto que contribuirá com diversas informações acerca da depressão no idoso institucionalizado que complementarão os resultados das pesquisas realizadas.

É importante ressaltar que no meio acadêmico será transmitido novos conhecimentos levando em consideração que o estudo propiciará aos alunos a possibilidade de perceber, na pesquisa, informações que poderão ser agregadas e aplicadas na prática. E com isto preparar os estudantes de psicologia, pois os mesmos vão estar aptos para responder questões que são de grande relevância na atualidade. 


\section{REFERENCIAL TEÓRICO}

\section{O abandono familiar e o desencadeamento da depressão em idosos}

Segundo Silva et al. (2010), cada vez mais os familiares decidem colocar seus idosos em Instituições de Longa Permanência que são opções como moradias que tratam da especialidade geriátrica buscando atender as necessidades individuais de cada idoso internado proporcionando os cuidados necessários.

De acordo com a resolução da ANVISA, ILPIs são instituições governamentais ou não-governamentais, que possui caráter residencial, sendo destinadas a domicílio coletivo de pessoas com idade igual ou superior a 60 anos, com ou sem suporte familiar, em condição de liberdade, dignidade e cidadania.

Segundo Pollo (2008) ILPI é definida como estabelecimento para atendimento integral institucional para idosos dependentes ou independentes nas atividades de vida diária, que não possuem condições para permanecer com a família ou em seu domicílio.

A terminologia ILPI foi adotada em substituição ao termo "asilo", cujo não era apropriado para descrever esses espaços sociais, porém até chegarem à definição da referida terminologia, houve várias discussões entre a sociedade civil, o Estado e as instituições que não prestavam cuidados aos idosos. Visto que o termo asilo denotava sentidos que emergem a depreciação, originando diversos preconceitos. (CRISTOPHE; CAMARANO, 2010).

Telles (2002) descreve que os motivos para a internação nas ILPIs, incluem as dificuldades das famílias em acolhê-los por falta de espaço, recursos, estrutura familiar que respeite o idoso ou por incapacidade de cuidar deles devido a situações especiais como inserção dos membros no mercado de trabalho, abandono pela família, dificuldades de encontrar um cuidador, pobreza, viuvez e opção do próprio idoso por se achar um entrave para a família.

Segundo Davim et al. (2004), as instituições de longa permanência não devem configurar-se apenas como locais que acolhem idosos abandonados pela família, mas também devem ser compreendidos como uma escolha dentro de um contexto de vida do idoso.

Para os idosos que não têm mais um vinculo com seus familiares, este acontecimento pode gerar no idoso um sentimento de exclusão quando este se encontra afastado de tudo o que fazia parte de sua vida antes da institucionalização, gerando neles um sentimento depressivo (OLIVEIRA et al. , 2011)

Segundo Manjabosco (2014) a vivência do desamparo é singular a cada sujeito e vai em função da sua organização psíquica. Portanto muitos ficam doentes mais rápidos, física ou psicologicamente, por conta desse abandono.

Além disso, segundo Born (2006) sentimentos de desamparo e abandono tende a ser gerados nos idosos residentes de ILPI causando estados depressivos. Conforme Hartmann (2012, p. 45):

Os idosos institucionalizados compreendem a transferência do lar para uma ILPI como desafio, pela radicalidade da mudança a que são submetidos. Desse contexto fazem parte sentimentos de abandono pelos filhos, de perda de liberdade, de autonomia, de identidade, de isolamento e de inatividade física, especialmente quando as ILPI contemplam exclusivamente a assistência social.

Aproximadamente $15 \%$ dos idosos apresentam quadro de sintoma depressivo, sendo que $2 \%$ destacam-se como sendo grave. Em pacientes que estão hospitalizados o índice é de $5 \%$ a $13 \%$ enquanto pacientes institucionalizados a presença é de $12 \%$ a $16 \%$ o que evidência o aumento significativo em relação o desencadeamento da depressão nesses idosos. (SIQUEIRA et al. , 2009).

O ingresso nos lares de longa permanência é feito por empurrão quando os familiares dos idosos decidem inconsequentemente, pelo seu internamento, ou mediante negociação quando os próprios idosos por viverem sós, por não quererem constituir-se um fardo para a família, ou porque estes não lhe prestam a ajuda pretendida, acolhem o internamento como inevitável ou mal menor (PAIS, 2006, p.146).

Para o idoso institucionalizado, as perdas são muitas, e isto justifica a grande incidência de estados depressivos, sentimentos de solidão e limitação das possibilidades de uma vida ativa. (DANILOW et al. 2007). 


\section{0 processo de envelhecimento e as consequências biopsicossociais}

Segundo, World Health Organization (2015) são consideradas idosas pessoas com idade cronológica acima de 60 anos se residentes em países em desenvolvimento, e acima de 65 anos, se vivem em países desenvolvidos.

O processo de envelhecimento começa desde a concepção sendo definido como um processo dinâmico e progressivo no qual há modificações tanto morfológicas quanto funcionais, bioquímicas e psicossociais, as quais determinam a progressiva perda da capacidade de adaptação do indivíduo ao meio ambiente. (DZIECHIAZ 2014, apud DANTAS; SANTOS, 2017, p. 20).

De acordo com Dantas e Santos (2017), o envelhecimento é um fenômeno natural, universal, irreversível e não ocorre de forma simultânea e igualitária nos seres humanos. Envelhecer faz parte da vida e, visto à luz dos conhecimentos atuais, não há nada que se possa fazer para alterar esse processo.

Costa (2002) ressalta que o envelhecimento é um fator inerente à vida humana, acontecerá a todos sem distinção de classe social, credo ou ideologia política. Poderemos retardá-lo ou mascará-lo, mas nunca, em nenhuma hipótese impedi-lo.

De acordo com Robergs e Roberts (2002) o envelhecimento não se limita em apenas o passar do tempo, mas são manifestações de eventos biológicos que ocorrem ao longo de um período, onde não deve ser visto como doença e sim como um processo natural, ou seja, qualquer coisa nesse planeta envelhece com o tempo, não apenas os seres humanos.

Para Spirduso (2005) o envelhecimento refere-se a um conjunto de processos que ocorrem em organismos vivos, que com o passar do tempo levam a perda de adaptabilidade, deficiência funcional, e por vez a morte.

Segundo Vono (2007) o processo de envelhecimento engloba diversos fatores ao decorrer do tempo, por exemplo, as células que compõe o organismo humano acabam envelhecendo, algumas se renovam outras não, enquanto umas reduzem em número e atuam de forma menos efetiva, no caso os neurônios. Contudo o envelhecimento deve ser avaliado não só sob ponto de vista cronológico, mas também biológico, psíquico, social.

As modificações biológicas são: as morfológicas, reveladas pelo aparecimento de rugas, de cabelos brancos e outras; as fisiológicas, relacionadas às alterações das funções orgânicas; e as bioquímicas, que estão diretamente ligadas às transformações das reações químicas as quais se processam no organismo; b) as modificações psicológicas ocorrem quando, ao envelhecer, o ser humano precisa adaptar-se a cada situação nova do seu cotidiano; c) as modificações sociais são verificadas quando as relações sociais são alteradas em razão da diminuição da produtividade e, principalmente, do poder físico e econômico, sendo a alteração social mais evidente em países de economia capitalista. (DANTAS; SANTOS, 2017, p.19)

0 envelhecimento não acontece em um mesmo ritmo nos aspectos físico, social, psicológico e cronológico. São aspectos distintos que merecem atenção em suas especificidades (OLIVEIRA, 2000)

0 conjunto de fatores que permitem ao indivíduo continuar a funcionar eficazmente tanto do ponto de vista físico como mental. Distinguem-se em três aspectos que deverão estar presentes no envelhecimento bem-sucedido: baixo risco de doenças, ou incapacidades relacionadas com a doença, funcionamento físico e mental elevado, empenhamento ativo na vida (ROWE; KANH, 2000, p.38).

As principais consequências do envelhecimento são crise de identidade, mudanças de papéis, aposentadoria, perdas diversas e diminuição dos contatos sociais (ZIMERMAN, 2000).

0 homem em desenvolvimento durante o ciclo da vida é um ser biopsicossocial, podendo sofrer influências e influenciar o ambiente em que vive num processo de adaptação, em suas relações com o mundo (RODRIGUES et al. , 2001).

Dessa forma, a idade avançada incita transformações biopsicossociais na rotina do ser humano. Além do desgaste progressivo de tecidos, órgãos e da capacidade física e cognitiva, há um acentuado processo de perdas que desencadeia turbulências emocionais e psíquicas que ocasionam profunda infelicidade e diminuem a qualidade de vida de maneira agressiva. (MACHADO et al. ,2012). 
De acordo com Harris et al. (2006) no processo de envelhecimento pode surgir a depressão em decorrência do sentimento de abandono, sendo considerada um fator primordial no desencadeamento e agravamento do declínio funcional, além de provocar um risco maior de mortalidade e suicídio. Há também exemplos de sintomas relacionados como a perda do sono, perda do prazer nas atividades habituais e sexuais.

O abandono de idosos em instituições de longa permanência e as consequências que acarretam esse abandono

O abandono é caracterizado como uma forma de violência que se manifesta pela ausência ou deserção dos responsáveis governamentais, institucionais ou familiares de prestarem socorro a uma pessoa idosa que necessite de proteção (MINAYO, 2005 p.15 apud SOUZA, 2013 p.39).

Para Carboni e Reppeto (2007), o abandono ocasiona no indivíduo sofrimento impedindo-o de conviver e permanecer inserido tanto na família, quanto em grupos, rompendo o contanto vital com o mundo, dessa forma é favorável o sentimento de inércia do corpo roubando a possibilidade de ser e de conhecer.

A institucionalização do idoso conduz a um distanciamento progressivo da família, às vezes resultando no abandono (SILVA et al. 2007).

De acordo com Benincá et al.(2005) as causas mais frequentes do abandono estão associadas ao envelhecimento, visto que esse abandono surge aos poucos, primeiramente ocorre a internação do idoso e posteriormente os familiares reduzem as visitas.

Ainda de acordo com Benincá et al. (2005) quando os idosos encontram-se em condições de internamento, tendem a enfrentar sofrimento psíquico, desvalorização por parte dos familiares além de ter que encarar a saúde fragilizada.

Para Santos (2013) a Instituição de Longa Permanência para Idosos (ILPI) é um lugar de cuidados, onde a pessoa idosa recebe assistência com vistas ao atendimento de suas necessidades físicas, mentais e sociais, como também um espaço que lhe proporcione contato com a sociedade.

Devido às condições precárias de saúde, idade avançada e até mesmo distúrbio de comportamento muitos idosos não são capazes de exercer atividades laborais. Nesses casos somando-se as dificuldades financeiras e a falta de respaldo familiar há grande possibilidade de encaminhamento desses indivíduos para instituições asilares. (FILHO et al. , 2001, p.358).

Quando passa a fazer parte do ambiente institucional, o idoso tem dificuldade de lidar com as perdas, tais como de status e de papéis sociais, tendo de enfrentar problemas de saúde e de ordem econômica, isolamento, rejeição, marginalização social,entre outras questões (TAVARES,2007).

Para Tier (2006), o idoso é relegado a uma espécie de isolamento e muitas vezes privado de suas atividades familiares e sociais, vive uma situação limitada e prejudicada, e mesmo que ele tenha monitoramento da sua saúde física, algo lhe falta, como a mobilidade social, vida afetiva e sexual, além de autonomia financeira.

Alguns sentem tensão, angústia, desespero, insegurança, e, quanto maior for o potencial para a perda desse vínculo, mais intensas e variadas serão essas reações, podendo vir a prejudicar o indivíduo. Muitos idosos sentem vergonha em dizer que foram internados involuntariamente, preferindo argumentar que a internação se deu devido a problemas de saúde ou por falta de condição da família, tentando esconder as ameaças sofridas pelos próprios familiares (CARMO et al. 2013, p.331.)

Segundo Esteves (2019), as consequências desse comportamento podem ser devastadoras para a saúde já frágil do idoso. Sem perspectivas e desanimado por se sentir abandonado, a tendência é que se desenvolva um quadro depressivo, de negação de vida. Situações assim costumam ser determinantes para o agravamento de outras doenças. 


\section{0 desencadeamento da depressão em casos de abandono de idosos institucionalizados}

Para Gerritsen et al. (2011) a depressão além de ser um quadro patológico ocasiona graves consequências que incapacita o individuo, podendo interferir no cotidiano do mesmo, até nos aspectos mais simples. As ligações entre depressão e qualidade de vida necessitam de prioridade em prol de diagnóstico preciso e tratamento precoce.

A prevalência de depressão entre os idosos pode variar muito, dependendo do instrumento utilizado e da gravidade estudada. (GAZALLE, 2003 p.26 apud SILVA et al. 2012 p.3).

Segundo Vaz (2009) as mulheres estão suscetíveis duas vezes mais a terem depressão do que os homens, podendo ser explicada tal discrepância por fatores que envolvem desde o ambiente ao suporte social na maioria das culturas.

De acordo com Plati et al (2006) uma investigação foi feita, com o intuito de avaliar a frequência de sintomas depressivos e o desempenho cognitivo de idosos institucionalizados e não institucionalizados, e foi evidenciado que as maiores taxas de sintomas depressivos são existentes entre os idosos institucionalizados.

Segundo Siqueira et al. (2009), os sintomas da depressão são variados, indo desde as sensações de tristeza, passando pelos pensamentos negativos até as alterações da sensação corporal, como dores e enjoos.

De acordo com Bergdhal et al. (2005) vivenciar a solidão torna-se um indicativo de insatisfação, sendo assim, a solidão é apontada como um dos fatores de riscos para o desencadeamento da depressão em idosos institucionalizados.

Heller et al. (2012) ressaltam que os sinais e sintomas de depressão são tardiamente reconhecidos pelos profissionais de saúde, pelos próprios doentes e pelos seus cuidadores e familiares. 0 que contribui grandemente para o sofrimento daqueles que não recebem o cuidado adequado e em tempo útil.

A consequência mais séria de depressão tardia é o aumento da mortalidade por suicídio ainda mais na velhice do que na juventude, a depressão pode conduzir ao suicídio (ROTH, 2000).

Esta situação torna-se mais grave quando se refere a idosos institucionalizados onde o cuidado deveria ser mais próximo e prontamente se deveria fazer um diagnóstico precoce. (PONCINHO et al. 2009).

A institucionalização pode ser entendida como um duplo processo, por um lado, como recurso a serviços sociais de internamento do idoso em lares, casas de repouso e afins, onde recebe assistência, por outro pode entender-se a institucionalização como vivência de perda, simbolizada pela presença de estados depressivos, significando uma das formas como o idoso sente e vive o ambiente institucional (CARDÃo, 2009, p. 18).

A escassez de cuidados médicos e profissionais assíduos nestas instituições é apontada como a possível causa para a elevada prevalência de sintomas depressivos nos idosos institucionalizados (SIQUEIRA et al. 2009).

A depressão constitui-se como a perturbação afetiva mais frequente no idoso e é, atualmente, a principal causa de incapacidade em todo o mundo. É mais comum em idosos institucionalizados e na maior parte das vezes é subdiagnosticada e sub-tratada. Uma das razões apontadas é que, por um lado, os idosos têm maior tendência para alexitimia (a incapacidade para identificar e verbalizar as experiências afetivas) e, por outro lado, os sintomas depressivos entre os idosos podem muitas vezes ser mascarados por queixas somáticas ou sintomas físicos, não sendo tratados adequadamente por serem confundidos com algum tipo de demência. (VAZ; GASPAR, 2011 p. 8)

De acordo com Stella et al. (2002) as causas que acometem a depressão no idoso são vastas, incluindo componentes onde atuam fatores genéticos, eventos vitais, como luto e abandono, e doenças incapacitantes, entre outros. Sendo assim, é preciso levar em consideração que existem situações que tornam o sujeito susceptível ao estado depressivo. 


\section{Os fatores que contribuem para a prevenção da depressão em idosos institucionalizados}

A prevenção da depressão no idoso deverá passar pela criação de serviços sociais que apostem no acompanhamento desta população, através de atividades que promovam o designado envelhecimento ativo, como: a promoção da saúde, a continuidade de exercícios físicos adequados e adaptados às necessidades, a diminuição das barreiras físicas de forma a permitir maior mobilidade, a solidariedade informal e inclusão a atividade mental, a socialização do idoso. (LEITE et al. 2006, apud, FRADE et al. , 2015).

De acordo com Strawbridge et al. (2002) os aspectos preventivos que incluem atividades físicas têm forte associação entre saúde física e fatores preventivos da depressão na velhice. Além disso, como resultado das atividades é considerável o aumento da autoestima e idosos fisicamente mais ativos.

Segundo Jagadheesan et al. (2002) existe uma grande necessidade de se manter clareza quanto aos mecanismos neurobiológicos e psicológicos quanto a recuperação do paciente depressivo.

Mather et al. (2002) afirma que a atividade física quanto praticada regularmente, contribui para que seja minimizado o sofrimento psíquico em idosos que estão depressivos.

Segundo Stella (2002) as atividades em geral, sejam de ordem física ou não, possuem grande relevância para a qualidade de vida na velhice. Sendo que o exercício físico denominado aeróbio irá propiciar alivio de estresse e tensão devido ao aumento da taxa dos hormônios que se chamam endorfina desta forma, agirá no sistema nervoso reduzindo transtornos depressivos, o que já foi comprovado através de diversos estudos.

Para Hairdar (2016) uma medida importante para a prevenção da depressão no idoso é fazer com que o idoso perceba que ainda pode ser feliz, colaborando para que encontrem a felicidade dentro de si, com suas próprias realizações. 0 incentivo para formar grupos, estudar, fazer trabalhos voluntários, cultivar amizades e frequentar lugares para lazer, fará com que se sinta bem e inserido no meio em que vive.

Ainda de acordo com Hairdar (2016) todas essas atitudes aliadas aos cuidados médicos e remédios próprios para depressão farão com que o idoso tenha uma vida com qualidade. No que diz respeito a idosos doentes, apesar das restrições existentes, o acolhimento junto ao afeto será primordiais.

De acordo com Corbella et al. (2003) quando uma pessoa sente neutralidade em um ambiente tende a sentir-se confortável. Neste sentido, referente às instituições a arquitetura pode ser instrumento terapêutico e contribuir para o bem-estar físico do paciente junto à criação de espaços que acompanhem a tecnologia e desenvolvam um convívio mais humano.

\section{PROCEDIMENTOS METODOLÓGICOS}

A metodologia utilizada foi a revisão bibliográfica qual é feita por meio de artigos científicos, sites eletrônicos, livros e revistas cientificas. A pesquisa bibliográfica tem o intuito de levantar um conhecimento disponível sobre teorias, a fim de analisar, produzir ou explicar um objeto sendo investigado. A pesquisa bibliográfica visa analisar as principais teorias de um tema, e pode ser realizada com diferentes finalidades. (CHIARA, KAIMEN, et al. , 2008).

A pesquisa bibliográfica é aquela que se realiza, segundo SEVERINO (2007), a partir do:

[...] registro disponível, decorrente de pesquisas anteriores, em documentos impressos, como livros, artigos, teses etc. Utilizam-se dados de categorias teóricas já trabalhadas por outros pesquisadores e devidamente registrados. Os textos tornam-se fontes dos temas a serem pesquisados. 0 pesquisador trabalha a partir de contribuições dos autores dos estudos analíticos constantes dos textos (SEVERINO, 2007, p.122).

A pesquisa é baseada na revisão bibliográfica sistemática que tem abordagem qualitativa onde são pesquisados nos diversos meios de instrumentos sobre o assunto abordado utilizando descritores e Palavras chave que contribuirão para que a pesquisa seja realizada. Essa descrição levará em consideração os temas da pesquisa.

O método desenvolvido é de pesquisa qualitativa que reúne dados que são coletados de forma de narrativa, como diários, questionários abertos, entrevistas e observações que não são codificadas usando 
um sistema numérico. Neste tipo de pesquisa são fornecidas informações sobre um problema ou ajuda para desenvolver idéias ou hipóteses. A pesquisa qualitativa também é usada para descobrir tendências de pensamento e opiniões.

Para elaboração desta pesquisa foram utilizadas ferramentas virtuais que abrangem: Google acadêmico, SciELO, livros, revistas eletrônicas e biblioteca virtual em saúde (BVS). Todo material citado contém dados confiáveis de cunho científico que permitem a coleta de informações para que seja realizada a pesquisa sobre o tema abordado.

Após a seleção dos documentos que foram utilizados para a elaboração da pesquisa realizou-se uma seleção das informações utilizadas através de fichamentos e resumos, esses métodos serviram para facilitar a organização da pesquisa. Posteriormente os dados coletados serviram para a construção do trabalho de forma efetiva.

Os critérios de inclusão utilizados foram: livros, artigos científicos em português e inglês para se ter uma extensão maior de conteúdos explorados, sendo que todos são estudos publicados a partir do ano 2000 . Levando em consideração que as pesquisas realizadas que não atenderam aos métodos de inclusão não foram úteis na construção deste projeto. Foram considerados os termos de busca: depressão, abandono familiar, processo de envelhecimento, consequências biopsicossociais, abandono de idosos, consequências do abandono de idosos, desencadeamento da depressão em idosos institucionalizados, prevenção da depressão em idosos institucionalizados. Além disso, a busca teve como descritores os termos: idosos, depressão e instituição de longa permanência. A coleta de dados e leitura do material iniciou no mês de setembro e seguiu até o mês de novembro, seguido das correções e sugestões do professor orientador.

0 presente trabalho reuniu o total de 52 referências pesquisadas que contribuíram para a execução sobre a temática do trabalho, sendo que a obras citadas neste TCC estão divididas abaixo:

- Foram utilizados 03 livros divididos em assuntos relacionados ao trabalho, em idioma português, publicados no período de (2002-2010).

- Os artigos científicos acessados constam nas bases de dados do Scielo e Google acadêmico. Sendo que foram 30, divididos em nacionais e internacionais (inglês) e (espanhol), disponíveis online em texto completo, entre o período (2000-2010).

- Foram utilizados 13 artigos de revistas científicas onlines disponíveis na web com temas relacionados ao estudo, entre o período (2010-2020).

- Foram utilizadas cinco dissertações de mestrado disponíveis nas bases do Google acadêmico, publicada entre (2008-2019).

- Por fim, uma monografia disponível nas bases do Google acadêmico, publicada em: (2010).

Em relação à ética é garantido não se apropriar indevidamente de pensamentos de outros, evitando plágios, sendo integro, moral e justo não adulterando as informações das fontes e mantendo a autoria claramente creditada ao verdadeiro autor através das citações e referências.

\section{RESULTADOS E DISCUSSÃO}

\section{0 processo de envelhecimento e as consequências biopsicossociais}

Para Dantas e Santos (2017) o processo do envelhecimento acontecerá de formas diferentes nos seres humanos, sendo parte primordial da vida. Costa (2002) afirma que o envelhecimento chegará a todos, sendo que alguns utilizarão meios para tentar camuflar a idade. A priori o ato de envelhecer é encarado pela a maioria das pessoas como consequência natural da vida, contudo o que às vezes passa de forma despercebida é que cada ser humano vivenciará esse processo de maneiras diferentes.

A princípio é normal que ao decorrer do processo de envelhecimento algumas pessoas sintam-se com medo, logo que $o$ ato de envelhecer remete a uma vida com limitações e consequentemente alguns agravos em relação à saúde. Diante disso, Robergs e Roberts (2002) referem-se ao envelhecimento como um processo normal que ocorre na vida, além do que não deve ser encarado como doença e visto acerca apenas da perspectiva de limitações, já que envelhecer é um processo natural, isto é, tudo que se faz existente no mundo ao decorrer dos anos envelhece, deixando claro que o acometimento da velhice não acontece apenas com os seres humanos. Por outro lado, Spirduso (2005) acresce que indubitavelmente a velhice trará uma série de consequências aos seres humanos de tal modo, que tantos os fatores biológicos 
quanto o emocional sofrerá danos como: diminuição na probabilidade de adaptar-se ao novo, presença de doenças crônicas, redução ou impossibilidade de realizar tarefas específicas, tanto laborais quanto socais, dentre outros fatores até que se chegue ao final da vida.

Dziechiaz (2014) enfatiza que o processo de envelhecimento se inicia desde a concepção sendo suscetível a passar por diversas etapas que influenciarão o indivíduo adaptar-se ao meio o qual está inserido. Vono (2017) acresce que o envelhecimento não deve ser levado apenas pela ótica cronológica reforçando que o biológico, psíquico e social faz parte desse processo. Contudo Oliveira (2000) aponta que o processo físico, social, psicológico e cronológico acontecerá de maneiras diferentes, sendo que cada um dos aspectos citados merece plena atenção individualmente em decorrência do quão significativo e importante os mesmos se fazem para que se possa encarar a velhice com mais propriedade.

Dantas e Santos (2017) explicam como ocorre às etapas biológicas, fisiológicas, bioquímicas, psicológicas junto às modificações sociais de forma minuciosa para que se haja um entendimento com maior precisão sobre todos esses processos. Rowe e Kanh (2000) ressaltam a importância de saber distinguir todos os fatores biopsicossociais, pois com isso será possível se ter uma vida menos prejudicial e mais adaptável as mudanças que por ventura surgirão.

No que concerne as consequências do processo de envelhecimento Zimerman (2000) afirma que é imprescindível que as mudanças de papéis, o fato de o idoso ter que se aposentar, as perdas as quais são submetidos junto com os afastamentos dos contatos sociais, terão um peso significativo na vida dos idosos. Rodrigues et al. (2001) refere que o homem é um ser biopsicossocial em virtude disso passará por diversas influências ao longo da vida, tendo que se adaptar-se diante as diferentes situações impostas que surgirão dia após dia, ou seja, viver é a forma como o indivíduo relaciona-se com o mundo. Para complementar Machado et al, (2012) salienta que conforme a idade vai avançando as transformações biopsicossociais vão acontecendo junto aos desgastes dos tecidos, órgãos, capacidade física e cognitiva reduzidas, resultando em indivíduos que estarão mais suscetíveis a sofrerem emocionalmente e psiquicamente.

Tratando-se das consequências no processo de envelhecimento diante ao que foi exposto pelos os autores, entende-se que o ser humano talvez nunca alcance todos os aspectos biopsicossociais em sua totalidade para somar uma vida significativamente perfeita, contudo a forma como se interpreta os acontecimentos e se vive, poderá influenciar positivamente ou negativamente no decorrer da vida de cada pessoa.

\section{O abandono familiar e o desencadeamento da depressão em idosos}

A terminologia ILPL é proveniente do termo asilo, cujo para chegar a tal delimitação foram necessárias muitas discussões acerca da importância da mudança de nome, pois o antigo termo remetia a sentidos de desqualificação, não dando ênfase ao que de fato as ILPIs gostariam de emitir em relação à prestação dos serviços de cuidados que prestariam aos idosos. As Instituições de longa permanência acolhem idosos na faixa etária dos 60 anos de idade que não possuem apoio e estrutura familiar, ou que por vontade própria buscam a institucionalização por não se sentirem protegidos e até mesmo rejeitados dentro do próprio lar. Tendo em vista que o atendimento tende a ser integral com intuito de oferecer uma vida digna e condições de longevidade buscando promover o bem-estar dos idosos. Por conseguinte, vale ressaltar que apesar das boas propostas das ILPIs, o sistema não funciona com total validez, abrindo brechas para um amontoado de descasos e ineficiência no atendimento e hospitalidade com o idoso. (ANVISA, 2015; POLLO, 2008; CRISTOPHE, CAMARANO, 2010).

Para Telles (2002) são diversos os motivos das famílias abandonarem os idosos em ILPIs (Instituições de Longa Permanência para Idosos), tais como: falta de espaço, recursos, estrutura familiar solidificada dentre outros, os quais são usados como argumentos para justificar o motivo do abandono para com o idoso. Por outro lado, Filho et al. (2001) reforça que a constituição familiar está cada vez mais dispersada, trazendo a idéia de que o abandono partirá do princípio das inúmeras possibilidades existentes de encaminhar o idoso para as ILPIs. Sendo assim, as possíveis probabilidades para encaixar os idosos em instituições, acaba por despertar o interesse dos familiares que por ventura optam ou não possuem condições de manter o idoso dentro da estrutura familiar existente.

Para Oliveira et al. (2011) a partir do momento que a família afasta o idoso de seu lar buscando instituições de longa permanência é um grande motivo que tende ocasionar além da depressão, o acúmulo de diversos outros pontos negativos que serão prejudiciais para o contentamento do idoso. Em conformidade Born (2006) afirma que os idosos residentes de ILPIs, em virtude do abandono familiar estarão sujeitos a sofrerem com estados depressivos. 0 que tende a ser um motivo impactante para a vida 
do idoso, pois no momento em que se esperar viver a plenitude da velhice de maneira leve e saudável, as expectativas são interrompidas, o que inspira tristeza pelo seu caráter doloroso.

Danillow et al. (2007) salienta que são muitas as perdas sofridas pelos os idosos ao serem institucionalizados, levando em consideração que a partir do referido momento as limitações surgem, abrindo lacunas para os sentimentos de solidão e como consequência a depressão. Hartmann (2012) expõe da mesma ideia, complementando que a compreensão dos idosos institucionalizados é vista por um contexto em que os sentimentos de abandono por parte dos filhos são totalmente potencializados, onde começa a gerar no idoso o sentido de várias perdas e inatividade. Em vista disso, faz-se necessário reforçar que a institucionalização do idoso, ainda não pode ser vista como uma alternativa favorável, pois o conjunto de necessidades e atenção que o idoso necessita para sobreviver até os últimos dias de sua vida, não são supridos totalmente.

Manjabosco (2014) expõe a idéia de que algumas pessoas adoecem mais rapidamente do que outras, devido os contextos que envolvem desde a singularidade até a organização psíquica. Por conseguinte, as singularidades e organizações psíquicas são elementos primordiais para a constituição da saúde humana, não podendo ser descartadas no processo que infere também ao adoecimento do mesmo. Siqueira et al. (2009) por sua vez, constata através de pesquisas que os idosos institucionalizados evidenciam o maior número de quadros depressivos em relação aos idosos que não são institucionalizados ou que se encontram hospitalizados. Deste modo, fica-se claro que o abandono de idosos em ILPIs é um dos agravantes que mais eclodem a depressão no idoso.

\section{O abandono de idosos em instituições de longa permanência e as consequências que acarretam esse abandono}

Silva et al. (2007) evidenciam que a institucionalização do idoso tem como consequência o distanciamento dos familiares que na maioria das vezes afastam-se gradativamente, tendo como resultado o abandono. Quando o abandono é constatado pelos idosos muitos sentimentos vêm à tona, dentre eles o sofrimento tende a ser o mais perverso, pois toda vitalidade do idoso apaga-se junto às esperanças e as possibilidades de se ter um convívio digno e respeitado pelos familiares e sociedade (CARBONI; REPETTO, 2007).

Minayo (2005) ao pormenorizar o abandono evidenciou que a prática do mesmo pode ser caracterizada como violência, uma vez que os familiares, responsáveis governamentais e institucionais começam a romper com o compromisso de prestar os cuidados, serviços e a proteção que o idoso precisa. Benincá et al. (2005) reforçam a ideia que o envelhecimento é uma das causas mais presentes quando se é falado sobre o abandono do idoso, logo que após a institucionalização do idoso os familiares perdem o interesse em visitá-los. Em vista disso, nas condições de internamento fatores agravantes tendem assolar os idosos, tais como: sofrimento psíquico, depreciação dos familiares e ter que lidar com a saúde debilitada.

Por conseguinte, Esteves (2009) afirma que são inúmeras as consequências ocasionadas na vida do idoso devido o comportamento de abandono por parte dos familiares, onde possivelmente ocorrerão quadros depressivos e perspectivas de vida reduzidas. Tier (2006) aponta que o idoso se sente postergado e o lugar onde poderia ser visto como refúgio para si acaba sendo uma prisão física e emocional, onde mesmo que haja acompanhamento de profissionais para o monitoramento da saúde, a sensação de perda prevalecerá.

No que refere às Instituições de longa permanência para os idosos, Santos (2013) expõe que devem ser prestados serviços com profissionais qualificados para os cuidados necessários com os idosos, visando oferecer atendimentos com dignidade conforme a necessidade que cada um apresenta, não se esquecendo de proporcionar espaços amplos para obtenção de contatos com a sociedade de maneira geral. Desta maneira, Tavares (2007) ressalta a importância de o ambiente institucional seguir com as normas pospostas, uma vez que os padrões não sendo atendidos serão refletidos no idoso de forma negativa.

\section{0 desencadeamento da depressão em casos de abandono de idosos institucionalizados}

Gerritsen et al. (2011) explicam que a depressão deve ser vista como um quadro patológico grave que ocasiona grande impacto na vida dos indivíduos, onde desde os afazeres mais simples geram sentimentos de incapacidade e frustrações, as atividades diárias começam a perder o sentido e a qualidade de vida consequentemente é reduzida. Por isso, faz-se necessário que a depressão seja diagnóstica imediatamente para que o tratamento devido seja feito. Contudo, o tardar do diagnóstico pode acarretar em problemas mais sérios. Heller et al. (2012) concluíram que pelo fato da demora em reconhecer os sinais e sintomas 
que a depressão evidência, o sofrimento daqueles que não recebe os devidos cuidados imediatamente é multiplicado. Considerando essa problemática Gazalle (2003) expõe que para constatar a prevalência de depressão entre os idosos é necessária a utilização de instrumentos devidos, a fim de estudar a gravidade da depressão que pode variar muito. Portanto, identificar o grau da depressão que acomete o idoso é primordial para que o tratamento devido seja feito.

Posteriormente Vaz (2009) afirma que as mulheres estão mais propícias que os homens em serem acometidas pela depressão devido à soma de múltiplos fatores que envolvem os aspectos biológicos e sociais. Nesse contexto Plati et al. (2006) iniciou uma investigação tendo como objetivo avaliar a frequência com que ocorre a depressão, o desencadeamento dos sintomas depressivos e desempenho cognitivo dos idosos que se encontram institucionalizados e aqueles que não vivem sob as mesmas condições. Em suma foi constatado que os índices de sintomas depressivos são maiores e mais frequentes em idosos que estão institucionalizados. Sendo assim, Bergdhal et al. (2005) constata através de seus estudos que a solidão concomitantemente a institucionalização do idoso são fatores de riscos que causam a depressão.

Siqueira et al. (2009) por sua vez enfatizam os sintomas depressivos onde a tristeza contínua é umas das sensações mais evidentes, seguida de pensamentos negativos que findam em alterações corporais, onde a pessoa tem sensações de enjoos e dores em partes específicas do corpo. Para Roth (2000) o fator mais agravante do diagnóstico demorado da depressão é o aumento de casos de suicídios entre os idosos.

Desta forma, Poncinho et al. (2009) refere que os idosos institucionalizados merecem mais atenção diante as necessidades que possuem, pois quando são diagnosticados e tratados a tempo, as expectativas de vida são aumentadas. Acrescentando-se da importância do diagnóstico precoce vale ressaltar quão significativo o mesmo é, inclusive os familiares e a equipe de cuidadores das instituições devem estar atentos e preparados para oferecerem todo suporte que os idosos necessitam. Conforme Siqueira et al. (2009) existe uma grande escassez de profissionais que trabalhem assiduamente em prol dos cuidados com os idosos nas instituições de longa permanência, o que é preocupante, visto que os idosos além de encararem o abandono familiar, ainda ficam à mercê de serem bem tratados ou não em um ambiente totalmente novo $\mathrm{e}$ por vez desconhecido.

Conforme Cardão (2009) a institucionalização abrange dois sentidos, sendo que por um lado pode ser vista como um recurso útil de internamento para o idoso onde será amparado com todas as regalias e serviços possíveis, por outro lado pode ser entendida como perda de viver a vida devidamente, pois o idoso tende a começar sofrer com quadros depressivos, levando em consideração a forma como ele se sente dentro do ambiente institucional. Vaz e Gaspar (2011) salientam que a depressão é um das causas que mais incapacitam as pessoas em todo o mundo, sendo frequente principalmente em idosos que se encontram institucionalizados, nesse ínterim a explicação cabível é que os idosos estão mais suscetíveis em não verbalizar o que sentem, outro fator relevante é que os sintomas depressivos costumam ser disfarçados por serem confundidos com sintomas de demência ou queixas somáticas e físicas. Em conclusão Stella et al. (2002) associa a depressão no idoso com constituintes genéticos, fatos vitais que trazem diversas modificações em suas vidas, dentre doenças que são incapacitantes. Em resumo, é extremamente necessário não desconsiderar os eventos e situações que ocorrem diante a vida que tornam os sujeitos passiveis de encarar a depressão.

\section{A prevenção da depressão em idosos institucionalizados}

Conforme Leite (2006) os idosos necessitam de serviços sociais que ofereçam amplitude para o devido acompanhamento desta população, ora que as possibilidades de um envelhecimento ativo são importantes, além de atuar como fator preventivo da depressão. Sendo assim, um conjunto de práticas devem ser realizadas que se iniciam desde exercícios físicos adaptáveis, conforme as necessidades de cada um, inclusão de mobilidade e diminuição das barreiras que interferem para qualidade de vida do idoso, Tendo em vista que esses fatores quando atuantes dentro das instituições tem intuito de prevenir futuras doenças e a depressão. Seguindo essa mesma perspectiva Strawbridge et al. (2002) afirma que a prevenção da depressão em idosos torna-se eficiente a partir do momento que são realizadas atividades físicas trazendo resultados notáveis que provocam positivamente na vida dos idosos, considerando que a saúde física refleti para o desenvolvimento da autoestima.

Jagadheesan et al. (2002) discuti a importância das necessidades dos mecanismos neurobiológicos e psicológicos diante a recuperação dos pacientes depressivos. Por outro lado, Mather et al. (2002) refere 
que quando as atividades físicas são praticadas seguindo um determinado ritmo, minimiza o sofrimento de idosos que estão depressivos.

Paralelamente ao exposto, Stella (2002) atribui que atividades desenvolvidas com idosos de modo geral, destacam-se significativamente na melhoria de vida na velhice, trazendo ênfase aos exercícios físicos que asseguram supremo desempenho no sistema nervoso central, concomitante a redução de transtornos depressivos. Hairdar (2016) complementa que quando o idoso tem a percepção de uma vida feliz, cuidados da equipe médica e utiliza medicações apropriadas, são fatores que colaboram para a prevenção da depressão. Com isso estimular o idoso dentro do ambiente de institucionalização com a inclusão de mutuas tarefas, oferecer acolhimento e afetividade faz com que o idoso se sinta de fato incluído na sociedade mesmo que em situações fora do contexto comum. Ainda por cima, quando os ambientes de institucionalização oferecem estruturas que transmitem segurança e conforto, tende a ser reconhecido pelo idoso como instrumento terapêutico possibilitando um convívio mais humano e digno (CORBELLA, YANNAS, 2003).

\section{CONSIDERAÇÕES FINAIS}

No decorrer da construção do presente trabalho foram encontradas algumas barreiras em relação às pesquisas da temática abordada, visto que apesar dos diversos meios existentes para a exploração e coleta de dados, quando se fala em depressão nos idosos institucionalizados o tema acaba que por afunilar-se, tendo em vista que é um assunto não muito abordado na atualidade.

Através do presente estudo, pode-se compreender as diferentes formas que levam os idosos a serem institucionalizados, bem como as dificuldades encontradas pelos mesmos ao serem transferidos para um lugar novo e desconhecido, cujo causa estranheza e consequências tais como a depressão em virtude das condições de vida e saúde que estarão suscetíveis a enfrentar.

No entanto, constatou-se que a institucionalização do idoso tende a ter situações em que o próprio idoso escolhe interna-se nas ILPI's, por não ter o amparo familiar necessário. Contudo, ficou-se claro que grande parte dos idosos residentes dessas instituições são abandonados pela família não somente quando deixados internados a mercê dos cuidados de outros, contudo quando os familiares se afastam gradativamente dos idosos tanto fisicamente quanto afetivamente. Evidenciando-se ainda mais a probabilidade do desencadeamento da depressão nesses idosos.

Ao longo desta pesquisa constatou-se que a depressão não é uma consequência natural do envelhecimento, existem fatores agravantes e desencadeantes por trás da história de vida da maioria dos idosos que se encontram depressivos.

Apesar das ILPI's visarem promover atendimento digno a população idosa a falta de profissionais capacitados nesses locais apresenta-se cada vez mais escassos, por vezes faltam equipes de profissionais qualificados para suprir as necessidades e realizar as intervenções que se fazem primordiais para a qualidade de vida do idoso.

Nesse sentido, baseado nas evidências que foram apontadas e discutidas sobre a depressão em idosos institucionalizados, seria imprescindível a construção de políticas públicas que visassem agir de forma mais abrangente nessas instituições, em prol do bem estar do cidadão idoso, bem como o trabalho de uma equipe multiprofissional para suprir as necessidades e realizar as intervenções que se fazem primordiais para a qualidade de vida do idoso. Dando ênfase ao trabalho da psicologia neste âmbito, uma vez que através de estratégias psicológicas seria possível que o profissional psicólogo preparasse o idoso para enfrentar os limites existentes como ajudá-los também, diante todos os conflitos que surgem durante a terceira idade.

\section{REFERÊNCIAS}

[1] ANVISA. Ministério da Saúde - Agência de Vigilância Sanitária, Resolução-RDC, N 283, de 6 setembro de 2005. [online]. Disponível em:

http://bvsms.saude.gov.br/bvs/saudelegis/anvisa/2005/res0283_26_09_2005.html. Acesso em: 03.NOV.2020

[2] BENINCÁ, C.R. FERNANDEZ, M.G. Cuidado e morte do idoso no hospital, vivência da equipe de enfermagem. Rev. Bras. de Ciênc. do Envelhecimento Humano.(Online), Passo Fundo. 2005. Disponível em: http://seer.upf.br/index.php/rbceh/article/view/27. Acesso em: 03.NOV.2020 
[3] BERGDAHL, E. et al. Depression among the oldest old: the study. International Psychogeriatric Association.[S.I],v. 17, n.4, p. 557-575,2005.

[4] BERTOLIN, G. VIECILI, M. Abandono Afetivo do Idoso: Reparação Civil ao Ato de não Amar. Rev. Eletrônica de Iniciação Científica. Centro de Ciências Sociais e Jurídicas da UNIVALI. (online), Itajaí, v. 5, n.1, p. 338-360, 2014. Disponível em: www.univali.br/ricc - ISSN 2236-5044. Acesso em: 02.MAR.2019

[5] BORN, T. BOECHAT, N. S. A qualidade dos cuidados ao idoso institucionalizado. Rev.Tratado de geriatria e gerontologia, Rio de Janeiro, v.2, p,1131-41, 2006.

[6] BROWN, M. LAPANE, K. LUISI, A. The management of depression in older nursing home residents.Journal of the American Geriatrics Society.[S.I], v.50, n. 1, p. 69-76, 2002.

[7] CAMARANO, A. A.Cuidados de longa duração para a população idosa: Um novo risco social a ser assumido.Fundação Instituto de Pesquisa Econômica Aplicada.Rio de Janeiro,p.145-162. 2010. Disponível em:

https://www.ipea.gov.br/portal/index.php?option=com_content\&view=article\&id=6586\%3Acuidadosde-longa-duracao-para-a-populacao-idosa-um-novo-risco-social-a-serassumido\&catid=265\%3A2010\&directory=1\&Itemid=1. Acesso em: 20.JUN.2020

[8] CARBONI, R.M. REPPETO, M.A. Uma reflexão sobre assistência á saúde do idoso no Brasil.[S.I] 2007. Disponível em: http://deploy.extras.ufg.br/projetos/fen_revista/v9/n1/pdf/v9n1a20.pdf. Acesso em: 03.NOV.2020

[9] CARDÃO, S. O idoso institucionalizado.Lisboa: Coisas de Ler.[S.I] 2009.

[10] CARMO, $\mathrm{H}$ et al. Idoso institucionalizado: o que sente, percebe e deseja.Revista Brasileira De Ciências Do Envelhecimento Humano, [S.I] 2013.

[11] CHIARA, I. D. et al. Normas de documentação aplicadas à área de Saúde.[S.I].Editora E-papers, 2008.

[12] COSTA, M. A. Cuidar idosos: Formação, prática e competências dos enfermeiros. 2006. (Dissertação de mestrado). (Instituto Politécnico de Bragança), para obtenção do titulo de mestre em Educação Social.

Disponível em:https://bibliotecadigital.ipb.pt/bitstream/10198/6863/1/Relato\%cc\%81rio\%20final.pdf. Acesso em: 05.OUT.2020

[13] CORBELLA, O. YANNAS, S. Em busca de uma arquitetura pata tópicos conforto ambiental. Universidade do Texas, editorial revan. 2003. Disponível em: https://sustentarqui.com.br/livro-em-buscade-uma-arquitetura-sustentável-para-os-trópicos. Acesso em: 14/01/2021

[14] COUTINHO, M.P. GONTIÉS, B. ARAÚJO, L.F. SÁ, R. C. N. Depressão um sofrimento sem fronteira: representações sociais entre crianças e idosos. Psicol. USF,[S.I]. v.8, n.2, p.182-91,2003.

[15] DANILOW, M. Z, et al. Perfil epidemiológico, sociodemográfico e psicossocial de idosos institucionalizados do Distrito Federal. Comum. Ciênc. Saúde. Brasília, v.18, n1, p. 9-16, 2007 Disponível em: https://www.scielo.br/scielo.php?pid=S180998232012000100016\&script=sci_arttext\&tlng=pt. Acesso em: 01.SET.2020

[16] DANTAS, H.E; SANTOS, S. A. Aspectos biopsicossocias do envelhecimento e a prevenção de quedas na terceira idade. [S.I]Editora, Unoesc, p. 19-330, 2017.

[17] DAVIM, R.M.B. et al. Estudo com idosos de instituições asilares no município de Natal/RN: Características socioeconômicas e de saúde.Rev. Latino-Americana de Enfermagem, vol. 1, n.3, p.518-524. 2004.

[18] DZIECHCIAZ, M. FILIP, R. Biological psychological and social determinants of old age: Bio-psychosocial aspects of human aging. Annals of Agricultural and Environmental Medicine; v. 21, p. 835-8, 2014.

[19] ESTEVES, G. Abandono familiar pode ter consequências graves em idosos.Tecnosenior. (online) Porto Alegre. 2019. Disponível em: https://tecnosenior.com/abandono-familiar-pode-ter-consequenciasgraves-em-idosos/. Acesso em: 12. SET.2020

[20] FRADE, J. BARBOSA, P. CARDOSO, S. NUNES, C. Depressão no idoso: sintomas em indivíduos institucionalizados e não-institucionalizados. 2015. (Artigo de investigação). Disponivel em:http://www.scielo.mec.pt/scielo. php?pid=S0874 028320150 00100005\&script=sci_arttext\&tlng=en. Acesso em: 05.SET.2020 
[21] GAZALlE, F.K, HALLAL, P.C, LIMA, M.S. Depressão na população idosa: os médicos estão investigando. Rev Bras Pisquiatr. v.26, p. 145-9.2004.

[22] GERRITSEN, D. SMALBRUGGE, M. TEERENSTRA, S. et al. Act in case of depression: The evaluation of a care program to improve the detection and treatment of depressio.n in nursing homes: Study protocol.PMC Psychiatry, v.11,p.91,2011. Disponível em: https://www.ncbi.nlm.nih.gov/pmc/articles/PMC3123630/. Acesso em:05.NOV.2020.

[23] HAIDAR, C. Depressão na terceira idade: saiba como prevenir. Boa Vontade. 2016. Disponível em:https://www.boavontade.com/pt/dia-dia/depressao-na-terceira-idade-saiba-como-prevenir. Acesso em: 10.NOV.2020.

[24] HARRIS T., COOK, D. G., VICTOR, C., DEWILDE, S., BEIGHTON, C. Onset and persistence of depression in older people results from a 2-year community follow-up study. Age and Ageing, v. 35, p. 2532, 2006. Disponivel em: https://academic.oup.com/ageing/article/35/1/25/33371. Acesso em: 03.NOV.2020.

[25] HARTMANN, J. A. S. Depressão em idosos institucionalizados. Tese de doutorado. Centro de Ciências da Saúde. Universidade Federal de Pernambuco. Disponível em: https://repositorio.ufpe.br/handle/123456789/326. Acesso em:20.NOV.2020.

[26] JAGADHEESAN, K. CHAKRABORTY, S.SINHA, V,K. NIZAMIE, S.H. Effects of exercise on depression in old age. British Journal of Psychiatry. 2002. Disponível em:

https://www.scielo.br/scielo.php?script=sci_arttext\&pid=S1516-44462016000300247. Acesso em: 15.JUN.2020.

[27] LIMA, M. S. et al. Depressão. In: KNAPP, P. Terapia cognitivo-comportamental na prática psiquiátrica. Porto Alegre: Artmed. 2004.

[28] MACHADO, ROSILEIA et al.0 envelhecimento e seus reflexos biopsicossociais. Unisuam. [S.I]. (online). v.2, n.1,2012. Disponível em: http://apl.unisuam.edu.br/revistas/index.php/cadernosunisuam/article/viewFile/116/301. Acesso em: 20.NOV.2019

[29] MANJABOSCO, R. O desamparo na velhice. Universidade Regional do Noroeste do Estado do Rio Grande do Sul, Departamento de Humanidades e Educação, Rio Grande do Sul, 2014. Disponível em: https://bibliodigital.unijui.edu.br:8443/xmlui/bitstream/handle/123456789/2654/rosa\%20manjabosco \%20-\%20tcc.pdf?sequence=1\&isAllowed=y. Acesso em: 20.DEZ.2020.

[30] MATHER, A.S. RODRIGUEZ, C. GUTHRIE, M.F. et al. Effects of exercise on depressive symptoms in older adults with poorly responsive depressive disorder. Randomized controlled trial. British Journal of Psychiatry,[S.I]. v, 180, p. 411-415, 2002.

[31] MINAYO, M. C. Pesquisa Social: Teoria, método e criatividade. 29. ed. Petropolis: Vozes, 2010.

[32] OLIVEIRA, E. R.; GOMES, M. R. ; PAIVA, K. M. Institucionalização e qualidade de vida de idosos da região metropolitana de vitória - ES. p.518 - 523, 2011.

[33] OLIVEIRA, R. C. S. Terceira idade: do repensar dos limites aos sonhos possíveis. São Paulo: Paulinas, 2000.

[34] Pais, J. M. Nos Rastos da Solidão - Deambulações Sociológicas.Porto: Ambar. 2006.

[35] PLATI, M.C.F. COVRE, P. LUKASOVA, K. MACEDO, E. Depressive symptoms and cognitive performance of the elderly: relationship between institutionalization and activity programs.Rev Bras Psiquiatr. V.28, n.2, p.118-21. 2006.

[36] POLLO, S.H.L. Instituições de longa permanência para idosos-ILPIS: desafios e alternativas no município de Rio de Janeiro. Rev. Bras. Geriatr. Gerontol. v.2, p.11, 2008.

[37] PONCINHO, $\mathrm{M}$ et al. Clinical and psychometric validation of geriatric depression scale for Portuguese elders.Clinical Gerontologist. v. 32, n.1, p. 223-236, 2009.

[38] RIEDEL, H. S. G., WEYERE S., KONIG, H. H., \& LUPPA, M. Depression in old age: Challenge for aging societies. Nervenarzt. v. 83. n.11, p. 1373-1378.

[39] ROBERGS, R. A. ROBERTS, S. O. Princípios fundamentais de fisiologia do exercício para aptidão, desempenho e saúde. São Paulo. 2002. Disponível em: 
http://bases.bireme.br/cgibin/wxislind.exe/iah/online/?IsisScript=iah/iah.xis\&src=google\&base=LILACS \&lang=p\&nextAction=lnk\&exprSearch=657415\&indexSearch=ID. Acesso em: 20.NOV.2020.

[40] ROTH, S. Aspectos clínicos, biológicos y sociales de las depressiones en la terceira edade. Actas españolas de Psiquiatria. v.28, n.7. p.337, 2000.

[41] ROWE, J. W. KAHN, R.L .Successful aging.New York: Dell Publishing .2000.(Dissertação de mestrado). (Instituto Politécnico de Bragança), para obtenção do titulo de mestre em Educação Social. Disponível em:https://bibliotecadigital.ipb.pt/bitstream/10198/6863/1/Relato\%cc\%81rio\%20final.pdf. Acesso em: 05.OUT.2020

[42] SANTOS, N.O. Família de idosos institucionalizados: perspectivas de trabalhadores de uma instituição de longa permanência. 2013. (Dissertação de mestrado). (Universidade Federal de Santa Maria) (UFSM, RS), para obtenção do título de Mestre em Enfermagem. Disponível em: http://coral.ufsm.br/ppgenf/Dissertacao_Naiana\%200liveirados\%20Santos.pdf. Acesso em 02.0UT.2020

[43] SEVERINO, A.J. Metodologia do Trabalho Científico. São Paulo: Cortez, 2007.

[44] SILVA C. A. CARVALHO, L. S. SANTOS, A. C. MENEZES, M. R. Vivendo após a morte de amigos: História oral de idosos. Rev. Texto \& Contexto Enfermagem,[S.I]. v. 16. n1, p.97-104, 2010.

[45] SIQUEIRA, GISELA ROCHA de et al. Análise da sintomatologia depressiva nos moradores do Abrigo Cristo Redentor através da aplicação da Escala de Depressão Geriátrica (EDG). Ciênc. saúde coletiva [online].vol.14, n.1, p. 253-259, 2009.

[46] SPIRDUSO, W. W. Dimensões físicas do envelhecimento. Tradução Paula Bernardi. Barueri: Manole, 2005.

[47] STELLA, F. et al. Depressão no Idoso: diagnóstico, tratamento e benefícios das atividade física. Motriz, Rio Claro, v. 8, n.3, p. 91-98, 2002.

[48] STRAWBRIGDE, W.J. DELEGER, S. ROBERTS, R.E. KAPLAN, G. Physical Activity Reduces the Risk of Subsequent Depression for Older Adults. American Journal of Epidemiology, v. 156, n. 4, p. 328-34, 2002.

[49] TELLES, F. P. Causas da inserção de idosos em uma instituição asilar. Rev Enferm.(Online) v.6, n.1, p. 135-43, 2002. Disponível em:

https://www.scielo.br/scielo.php?pid=S180998232012000100016\&script=sci_arttext\&tlng=pt. Acesso em: 01.SET.2020

[50] TIER, C. G. Depressão em idosos residentes em uma Instituição de Longa Permanência (ILP). 2006 (Dissertação de Mestrado). (Fundação Universidade Federal do Rio Grande do Sul), para obtenção de Mestrado em Enfermagem. Disponível em: https://www.scielo.br/scielo0016\&script. Acesso em: 05.OUT.2020

[51] VAZ, S. A. Depressão no Idoso Institucionalizado: Estudo em idosos residentes nos lares do distrito de Bragança. 2009. (Artigo de Investigação). Disponível em:

http://www.scielo.mec.pt/pdf/ref/vserIIIn4/serIIIn4a05.pdf. Acesso em: 05.NOV.2020.

[52] VONO, Z. E. Enfermagem gerontológica: atenção á pessoa idosa. São Paulo: Senac, 2007.

[53] WORLD HEALTH ORGANIZATION. Ageing and health. Fact sheet n. 404, 2015. Disponível em: http://www.who.int/ mediacentre/factsheets/fs404/en/ Acesso em: 05.0UT.2020

[54] ZINNEMANN, G. I. Velhice: aspectos biopsicossociais. Porto Alegre: Artmed, 2000. 


\section{Capítulo 5}

\section{O uso dos mecanismos psicológicos na influência de escolha do consumidor}

\section{Gabriela Brito Cavalcante}

Resumo: Com o desenvolvimento do mercado de consumo, as empresas buscaram por técnicas que destacassem seus produtos em relação ao que o mercado oferecia, percebendo na psicologia os mecanismos necessários para atingir de forma persuasiva 0 público-alvo. A partir disso, o objetivo central deste trabalho é compreender como os estudos psicológicos são utilizados na formulação de campanhas para influenciar na tomada de decisão do consumidor. Para alcançar a temática delineada, foram estabelecidos como objetivos específicos a investigação da relação entre o consumo e as técnicas de persuasão utilizadas, a discussão sobre o uso dos recursos emocionais na influência da tomada de decisão e a descrição de como as mensagens subliminares são propulsoras de comportamentos. A pesquisa realizada apresenta critério qualitativo, através da leitura sistematizada dos materiais, caracterizada por pesquisa bibliográfica. Constatou-se que, atualmente, a sociedade está focada no consumo assíduo de bens de fácil acesso, pautado no imediatismo, e que esse comportamento é baseado na influência ativa do marketing e da publicidade na interferência na tomada de decisão, utilizando de técnicas que interferem no consumismo. Com isso, as mensagens subliminares estão presentes nos mais variados segmentos e apresentam a capacidade de sugestionar na escolha, agindo na estrutura inconsciente do público-alvo. As respostas comportamentais de compra apresentam maior eficácia quando existe uma conexão emocional, com base nisso, as divulgações buscam construir correlações positivas sobre o produto vendido.

Palavras-chave: Consumo; Marketing; Publicidade; Subliminar; Persuasão. 


\section{INTRODUÇÃO}

Com o início da Revolução Industrial, surgem as primeiras fábricas e a produção em massa. Para lidar com o desenvolvimento econômico e mercadológico, os fabricantes passam a utilizar técnicas que destaquem seus produtos em relação à concorrência. Se antes a publicidade exercida pelas empresas tinha o intuito de informar, na era industrial passa a atuar com teor persuasivo no ato da compra.

A partir dos estudos elaborados sobre o comportamento do consumidor, tornou-se possível para a área do marketing moldar os produtos conforme as necessidades dos consumidores. Baseado no trabalho realizado entre o marketing e a divulgação, exercido pela publicidade a nível persuasivo, um método eficiente no controle e manipulação do comportamento é elaborado.

Duas manobras fundamentais são desenvolvidas na publicidade: o uso do apelo emocional e do apelo simbólico. No apelo emocional, a persuasão é atingida a partir de imagens ou textos associados a valores, mitos, ideias e composições simbólicas, para que alcance a estrutura cognitiva do público, influenciando no comportamento. E no apelo simbólico, se utiliza os símbolos para influenciar na percepção, nos sentimentos e, consequentemente, no comportamento, independente de definições ou explicações conscientes.

Outro fator existente na publicidade é o uso das mensagens subliminares, comumente disseminada nos meios de comunicação. De nível imperceptível, desenvolve-se no inconsciente de quem atinge, influenciando nas escolhas e nas decisões tomadas, principalmente, no comportamento do público.

A partir das questões levantadas sobre a influência na tomada de decisão dos consumidores, este trabalho teve como objetivo geral compreender como os estudos psicológicos são utilizados na formulação de campanhas para influenciar na tomada de decisão do cliente. Para alcançar o objetivo geral foram estabelecidos como objetivos específicos: a. Investigar a relação entre o Consumo e as técnicas de persuasão utilizadas; b. Discutir sobre o uso dos recursos emocionais na influência da tomada de decisão; e c. Descrever como as mensagens subliminares são propulsoras de comportamentos desejados.

O interesse despertado para que a referida temática fosse abordada, deve-se ao fato de que a autora buscou compreender, a partir de uma visão crítica, o mercado e as suas demandas consumistas que estão em constante crescimento e competitividade, que embora estejam em constância no cotidiano, pouco é investigado e criticado, mas que influencia profundamente no poder de escolha do consumidor.

Cientificamente, a presente pesquisa visou contribuir com o desenvolvimento de um material que explore o uso dos estudos psicológicos no desenvolvimento do marketing de produtos e empresas, pensados para conquistar o público - alvo desejado. No âmbito acadêmico, buscou-se fornecer um material científico que possa ser usufruído por quem tenha interesse em elaborar pesquisas relacionadas a temática, levando-se em consideração a pouca exploração dos objetivos estabelecidos, em contrapartida do desenvolvimento do consumo na sociedade.

E na perspectiva social, planeja-se que seja beneficiado o público que deseja compreender como suas pretensões e comportamentos são formulados, e como podem contornar a persuasão exercida por tais ferramentas, além de contribuir para que os desenvolvedores de campanhas explorem de forma assertiva o mercado consumidor.

\section{REFERENCIAL TEÓRICO}

\section{Psicologia do consumo: marketing e divulgação}

Segundo Justo e Massimi (2017), em uma perspectiva histórica, pode-se corroborar o surgimento do marketing e da psicologia do consumidor a partir da Revolução Industrial na Inglaterra, em 1780, e à publicação dos fundamentos da teoria econômica de Adam Smith, ambos movimentos ocorridos na Europa, que resultaram no crescimento econômico dos Estados Unidos. A publicação do livro A Riqueza das Nações, do ano de 1776, de Adam Smith, atuou como um dos elementos para modificar as relações comerciais e, consequentemente, os ambientes, pois ensinava que o aumento do lucro privado seria a base para a riqueza coletiva. A publicidade torna-se crucial nesse processo de desenvolvimento econômico. Muniz (2004) afirma que no contexto da Era Industrial, a publicidade passa a ter um novo objetivo: adquire um caráter persuasivo. Se no período pré-Industrial o objetivo exercido pela publicidade era de informar o público sobre o produto oferecido, na Industrialização, com o desenvolvimento dos mercados, 
a publicidade passa a ser mais ativa no comportamento de consumo.

E a partir da década de 60, pontua Paixão (2012), surge a necessidade de um estudo específico para compreender o comportamento do consumidor, advindo do crescimento da competividade no mercado. As empresas possuem como objetivo o desenvolvimento de estratégias para melhorar o mercado, proporcionado pelo entendimento a respeito do comportamento de compra. E compreender o comportamento do consumidor, proporciona para a área do Marketing a possibilidade de moldar determinadas empresas para que satisfaçam as necessidades do público-alvo, partir do processo de sondagem ou da análise das necessidades e desejos.

Fontenelle (2008) aborda que o behaviorismo e a psicanálise foram as principais abordagens da psicologia para a compreensão do comportamento do consumidor. No behaviorismo, J. Watson, após a carreira acadêmica nos princípios da ciência comportamental, inclinou seus estudos para a agência de advertising norte-americana, com o intuito de destrinchar as barreiras no entendimento sobre o ato de compra. Posterior a isso, a pesquisa motivacional, de base psicanalítica, surge como método de compreensão dos desejos humanos. Sabendo-se que a psicanálise teve seu início na área para aplicar as contribuições a respeito do inconsciente na relação indivíduo e consumo.

Nery, Torres e Menezes (2012) explanam que a publicidade, como principal ferramenta do marketing, torna-se um método eficiente no controle e manipulação do comportamento do consumidor. Utilizando-se do termo "novo" para persuadir o consumidor à ideia de que o produto ou serviço anterior é velho e precisa ser substituído. Fazendo um paralelo com o que Bauman (2007) chamaria de Sociedade LíquidoModerna de Consumidores; a publicidade compactua para a "cultura agorista" caracterizada, principalmente, pela renegociação do significado do tempo, priorizando a satisfação imediatista e renovável. Consumir não pode ser compreendido como um ato neutralizado, pois está diretamente relacionado com a disputa pelo o que é produzido, levantando conflitos mais enraizados da sociedade, como a desigualdade social e a forma de distribuição de "coisas" fabricadas.

É possível, inclusive, associar o surgimento de um movimento de consumidores, com o um grupo oriundo de Nova York, em 1891, que se autodeclararam New York Consumers League. No entanto, como afirma Guazzelli (2010), o objetivo principal desse grupo era constituído de uma noção bem diferente de consumismo dos atuais, pois se baseava na listagem de itens produzidos por empresas que respeitassem os seus funcionários, lutando contra a exploração nas fábricas, conduzindo os consumidores a uma compra mais consciente. Para Bauman (2007), o consumo é um comportamento quase que inato aos seres que compõe uma sociedade, podendo ser realizado por motivos "no automático" e em outros momentos de forma planejada e fundamentada. Sendo um comportamento que é desenvolvido desde início da vida em sociedade.

Em Psicologia das Massas, Le Bon (1895) explica que existem as multidões e multidões psicológicas. As multidões psicológicas não são baseadas em aglomerações de pessoas em um mesmo espaço físico, mas sim em aglomerações em pensamentos. Pessoas que de alguma forma se unem em um mesmo viés de pensamento estão compondo uma multidão.

O homem em sociedade, enfatiza Freud (2011), sucumbe aos desejos do coletivo, embora esse coletivo necessite de um "ser" maior que os domine. Correlacionando ao consumo, pode-se compreender que o consumismo é um "movimento" que define os padrões sociais de consumo a serem seguidos.

\section{Apelo emocional nas campanhas publicitárias}

A propaganda como principal meio de propagação mercadológica, como explicam Costa, Patriota e Angelo (2017), é difundida através dos meios de comunicação. Expondo como objetivo a divulgação de informação a respeito de produtos, serviços e ideias através de apelos e estratégias persuasivas. Ou seja, a publicidade agrupa manobras que misturam informação e persuasão com o objetivo de influenciar os sentimentos e o comportamento do público a que se destina. Compreendendo a tomada de decisão como resultante da influência da estrutura cognitiva e das crenças do indivíduo quando exposto ao objeto em questão.

Sauerbronn, Ayrosa e Barros (2009), elucidam que pesquisas realizadas nas últimas décadas apontaram que as emoções possuem um influente papel nas experiencias de consumo. 0 autor explana que o marketing enxergou na psicologia cognitiva a sua ferramenta fundamental para explorar e manejar à tomada de decisão. 
A partir da perspectiva de que a preferência de um indivíduo surge através de um fluxo de acontecimentos: o consumidor processa a informação, seguida pela avaliação cognitiva e afetiva e resultando no comportamento de compra. Na história do marketing abordou-se dois principais mecanismos de publicidade: racional e emocional. A publicidade racional baseia-se na explicação da utilidade do produto, pautado em uma comunicação direta com o público. Essa abordagem não atrai diretamente a atenção dos clientes, principalmente se o público estiver buscando por entretenimento, pois não possuem o objetivo em adquirir algum produto, tornando-se uma informação desnecessária. Com isso, Vakrasas e Ambler (1999) apud Huertas (2005) explicam que entre os modelos de divulgação utilizados existe o voltado para o estímulo da emoção pura. Esse modelo está voltado exclusivamente para as respostas emocionais e o uso da familiaridade dos sentimentos gerados na publicidade. Nessa modalidade existe a consciência de que a divulgação é o foco da mensagem, deixando a mensagem em si de lado. Isso ocorre a partir da mera exposição de elementos como sensação de bem-estar, felicidade e demais sentimentos e sensações propagadas através da mensagem.

Cardoso (2005) apud Lopes (2015) aborda que na manobra do apelo emocional, a publicidade se utiliza de valores, mitos, ideias e composições simbólicas, independente da finalidade, através de estímulos visuais ou por produção textual. É um componente fundamental, pois a persuasão está atrelada ao emocional do público atingido, influenciando no comportamento, no caso, no ato de compra. A publicidade emocional possui mais êxito no que diz respeito a captar a atenção do público em comparação a publicidade racional. Por que a emoção faz parte das decisões que são tomadas e dos comportamentos realizados. A partir da emoção, a publicidade pode transmitir a sensação de familiaridade para o público que consome o material.

A construção de uma sofisticada estratégia simbólica de comunicação, torna-se suficiente para a manipulação comercial. "Os símbolos afetam diretamente a percepção, os sentimentos e o comportamento. Eles não dependem de definições ou explicações conscientes” (KEY, 1996, p. 192). Para o autor, a mídia utiliza de forma intencional o uso de simbolismos para atingir a tomada de decisão do público. Explica que o simbolismo mais utilizando para atingir a essa manipulação são as ideias voltadas para a sexualidade e reprodução humana, pois atingem o desenvolvimento do comportamento neurótico e psicótico. A publicidade, embora utilize a vida cotidiana para explorar seus cenários, detém de um caráter mais otimista e convidativo, mostrando como as pessoas se vislumbram. Dudley (1999) apud Cunha e Sauerbronn (2013) explica que a publicidade apresenta personagens em papeis que transmitam sensualidade, perpassando a imagem de maior sociabilidade e sucesso, potencializando o reconhecimento do produto em questão. Desta forma, a publicidade faz o uso de informações com conotação sexual, com o objetivo de persuadir à ideia de que o consumo dos produtos resultará no mesmo efeito sexual e atrativo como o apresentado pelos personagens.

\section{Mensagens subliminares}

Mlodinow (2013) relata que grande parte do comportamento humano está relacionado aos estímulos inconscientes. Diferente dos estudos de Freud, o novo inconsciente, como cita o autor, está relacionado ao convívio e sobrevivência social, distante da ideia em que relacionava aos desejos sexuais parentais. 0 novo inconsciente está corroborado à comportamentos inatos, resultantes de fluxos de percepções, sentimentos e pensamentos, fusionados em planos conscientes e inconscientes.

Em comunicação, Amon et al. (2010) aborda que a mensagem subliminar pode ser compreendida como uma forma de propaganda subliminar, onde as pessoas são manipuladas e induzidas a apresentarem um comportamento de compra, através de mensagens escondidas e mascaradas. Funcionam a partir da percepção inconsciente, ocorre abaixo da percepção, tendo acentuada vantagem, pois o receptor não é capaz de exercer uma escolha.

Segundo Pullino (2016), a mensagem subliminar é comumente disseminada nos meios de comunicação, a partir das campanhas publicitárias e das propagandas políticas. Trabalha no inconsciente de quem consome o material. No caso do consumidor, age na influência para o ato de compra, a partir da exposição do telespectador à mensagem que não pode ser percebida de forma consciente. Agindo como uma mensagem invisível, atrelada ao que é perceptível.

As mensagens subliminares foram desenvolvidas nos anos 50. Em 1957, conforme relata Machado et al. (2002), na ocasião em que o consultor de marketing, James Vicary, alegou ter descoberto o uso de mensagens estrategicamente escondidas com o objetivo de influenciar no comportamento humano. Afirmando que durante a exibição do filme Férias de Amor, em um cinema de Nova Jersey, expôs os telespectadores a mensagens que influenciaram diretamente no aumento de vendas de pipocas e na 
bebida Coca-Cola. Por serem transmitidas num baixo nível de percepção, não são captadas pelos sentidos humanos e são executadas no subconsciente. "O que dizem os especialistas é que mensagens desse tipo nos são enviadas de forma oculta, abaixo dos limites da nossa percepção consciente, e que vão influenciar nossas atitudes, escolhas e motivar a tomada de decisões posteriores" (NERY; SILVA, 2007, p.218).

A partir da percepção dos enxertos subliminares, de nível inconsciente, torna-se quase impossível esquecê-los. É na memória que ocorre um dos principais impactos desencadeados pelos estímulos subliminares, influenciando no comportamento. Acredita-se que a memória abrange o armazenamento tanto de nível consciente quanto inconsciente. "Na superfície, os anúncios parecem inocentes, inofensivos e até insípidos. Eles são elaborados para serem assim percebidos. No entanto, os anúncios não são inocentes. A memória inconsciente tem uma enorme capacidade de armazenagem" (KEY, 1996, p.61).

Junior (2009) aborda a existência do modelo AIDA como explicação para o efeito da mensagem subliminar no receptor. Segundo o autor, as mensagens subliminares passam por componentes como: atenção, interesse, o desejo e a ação. Aborda que a atenção é um componente fundamental na influência, pois quanto maior a atenção concentrada do indivíduo a um determinado fator, maior será o nível de influência exercido sobre ele, sendo a ponte para persuasão. Quando o componente publicitário prende a atenção do consumidor, inicia a segunda etapa, a peça publicitária depende da análise do que é apresentado para o telespectador para que seja despertado o interesse e assim, iniciar a persuasão publicitária.

Após a mensagem ser captada, anterior à ação da compra, ela necessita ser alvo de desejo do potencial comprador. Kotler (1986) apud Junior (2009) explica que o despertar do desejo vai além da ação racional, pois também relaciona-se diretamente com o emocional do indivíduo, através dos componentes da campanha, como cores, formatos, sonoridades etc., sendo nesse momento que a campanha se utiliza de tais fatores influencia na escolha. No entanto, manobras como atrair a atenção, despertar o interesse e influenciar no desejo não são suficientes sem a ação. mais do que levado ao ato de usufruir por algo e manejar dinheiro em função disso, levar um indivíduo a exercer determinado comportamento está relacionado ao convencimento das vantagens e benefícios em elucidados pela campanha publicitária.

\section{0 inconsciente na publicidade}

A psicanálise recebe a sua primeira forma enquanto campo de investigação com as formulações realizadas por Sigmund Freud, considerando o pai da Psicanálise. Freud foi um médico, nascido no ano de 1856, em Viena. Iniciou a sua carreira como investigador, descobrindo a estrutura gonadal das enguias e, posterior, no campo da fisiologia, direcionando seu interesse pelo estudo do sistema nervoso, a priori, de certos peixes, como pontua Zimerman (2007). Freud nascerá em uma época onde a medicina estava inteiramente voltada para análise das estruturas biológicas, quase descartando-se o que era entregue como psicologia pelos filósofos.

Dentre as contribuições realizadas por Freud, Brandt (2018) explana que a relacionada com a temática da influência de tomada de decisão, considera-se o conceito de inconsciente. Freud, em seu trabalho em Viena, observa o aparecimento de quadros patológicos sem vestígios orgânicos, o que chama sua atenção e do colega chamado Josef Breuer. Ambos passam a discutir sobre a possibilidade de existência de um campo inconsciente do sistema psíquico dos pacientes que apresentavam os sintomas. Relata-se então, a existência de duas consciências, onde ambas apresentam pouca ou nenhuma comunicação, mas que influenciam diretamente no comportamento exercido pelos indivíduos: consciente e inconsciente.

No documentário The Century of the Self, Curtis (2002), a partir da teoria de Edward Bernays, comenta que para as grandes corporações é possível manipular o desejo das massas de adquirir bens que não necessitam, bastando associar os bens de consumo aos seus desejos inconscientes. A partir da satisfação dos desejos individuais de cada pessoa, era possível despertar um comportamento dócil, pois estariam felizes. "Foi o início do "eu" consumista que viria a dominar o nosso mundo moderno (CURTIS, 2002).

Ataíde (2011) aborda que um exemplo mostrado no documentário de como essa ferramenta começou a ser utilizada foi a inserção do público feminino no mercado tabagista. Até então, as mulheres se mostravam resistentes ao consumo do cigarro e seus afins. Bernays afim de modificar esse cenário, buscou nas formulações de seu tio Freud, a possível razão para tal, e descobriu na seção de "símbolos típicos", no capítulo VI do "A interpretação dos sonhos", que o cigarro é um símbolo do poder masculino, inconscientemente associado ao pênis. Com a descoberta, Bernays resolveu alterar essa imagem através da publicidade, associando o uso do cigarro a um desafio feminino ao poder masculino, mostrando, a partir de personagens, mulheres poderosas e autossuficientes fumando. $\mathrm{E}$ um fenômeno de massas ocorre: mulheres começam a fazer parte do mercado consumidor de tabaco. 
As representações internas e inconscientes apresentam representações simbólicas e abstratas. Esses símbolos desempenham influência emocional de difícil explicação racional, pois ultrapassando as interpretações, transformam-se em signo. Os símbolos apresentam conotação emocional, evocados por nomes ou imagens, possuindo conotações especiais além do significado evidente e convencional. "Representa ou substitui o objeto e tem um aspecto inconsciente, não precisamente definitivo" (CREPALDI, 2005, p. 3-4).

Freud (2011) aborda sobre o caráter "extraordinariamente" influenciável e crédulo que uma massa possui, em suma, não possuindo reflexão crítica frente aos acontecimentos e formulações propostas. Citando que o indivíduo pensa em imagens que evocam outras por associação, em um estado de livre devaneio, adentrando na postulação de que o indivíduo, estando em sociedade, desvencilha-se com maior facilidade de suas próprias aquisições, cedendo à instintos coletivos.

Le Bon (1895) a partir dos estudos formulados, acreditava que a raça prevalecia no indivíduo, o homogêneo pelo heterogêneo, onde componentes inconscientes que seriam comuns a todos prevaleciam, tornando-se operantes. Estando em sociedade, o indivíduo segue o que lhe é concebido como verdade maior, influenciado pela massa, pois todo sentimento e comportamento é contagioso, ao ponto de que sua subjetividade é posta de lado para ceder aos interesses coletivos, ou o que seria denominado como padrão.

\section{PROCEDIMENTOS METODOLÓGICOS}

A presente pesquisa apresenta caráter qualitativa, caracterizada por pesquisa bibliográfica. A pesquisa qualitativa tem como principal foco a compreensão geral de um grupo social em relação a um determinado assunto levantado. Os pesquisadores que optam por tal método, têm como objetivo compreender a explicação por trás de determinado fenômeno e o que pode ser realizado a respeito, sem que haja a necessidade de quantificação dos valores como prova de fidedignidade (GERHARDT, SILVEIRA, 2009).

Para Fonseca (2002) a pesquisa bibliográfica é o método que utiliza como embasamento, o levantamento de referenciais teóricos previamente analisados e publicados, a fim de copilar o máximo de informação para a estruturação da temática a ser abordada, possibilitando que o pesquisador utilize o que já fora explorado a respeito do assunto escolhido.

No tratamento das informações foi utilizado a leitura sistematizada do material desejado, sendo livros, artigos ou teses, observando a metodologia utilizada, dando importância também, para o referencial teórico usufruído pelo autor. A partir disso, consegue-se resumir os tópicos de seu interesse, tanto quanto o conteúdo a ser utilizado em seu trabalho (FROHLICH; DORNELES, 2011).

Tendo em vista a escassez de material com embasamento científico correspondente à temática, não se especulou um limite exato de anos de publicação, no entanto, foi priorizado materiais correspondentes à atualidade. Sendo as fontes obtidas nos idiomas português e inglês, com o intuito de abranger a viabilidade de obtenção de material para a referida pesquisa. Abordaram-se 21 livros, 29 artigos científicos, 4 teses, 1 blog especializado e 1 documentário. Sendo eles, em maioria, no idioma português, salvo o documentário abordado e um livro. Dentre os descritores utilizados estão: persuasão, publicidade, marketing, divulgação, subliminar, consumo e consumismo. Utilizando as seguintes plataformas para pesquisa: Scielo - Scientific Electronic Library Online, uma biblioteca eletrônica que possui um acervo selecionado de periódicos científicos; o Google Acadêmico, uma ferramenta disponibilizada pela Google para a pesquisa de publicações cientificas; o Portal da CAPES (Coordenação de Aperfeiçoamento de Pessoal de Nível Superior), disponibiliza textos integrais de artigos de revistas cientificas brasileiras e internacionais; BDTD - Biblioteca Digital Brasileira de Teses e Dissertações, reunindo um acervo com diversas publicações de trabalhos acadêmicos; dentro outros, sempre preservando as autorias dos respectivos materiais.

O levantamento de dados também foi explorado na Biblioteca do Centro Universitário - FAMETRO, localizado na Avenida Constantino Nery, número 3204 - Chapada, em Manaus - AM.

\section{RESULTADOS E DISCUSSÃO}

Neste capítulo serão apresentados os resultados obtidos a partir da pesquisa bibliográfica realizada sobre o uso dos mecanismos psicológicos na influência de escolha do consumidor. Para melhor compreensão os resultados foram divididos em três tópicos: 0 primeiro tópico "Vida para Consumo: Relação entre sociedade e consumo, teve como objetivo abordar, sob uma perspectiva histórica, o desenvolvimento das 
relações de consumo na sociedade. No objetivo do segundo tópico "Mecanismos persuasivos utilizados na formulação de campanhas" foi discutir sobre a transformação da publicidade como ferramenta de divulgação, utilizando a persuasão nas suas formulações para influenciar nas escolhas de consumo. Por fim, o terceiro tópico "A influência na tomada de decisão do consumidor" teve como objetivo descrever como as mensagens subliminares são aplicadas, de forma inconsciente, no comportamento dos consumidores, e o uso das conexões emocionais no desenvolvimento das divulgações.

\section{Vida para consumo: relação entre sociedade e consumo}

Bauman (2007) é conhecido com um dos principais autores que abordam sobre o consumismo. A partir de suas teorias, compreende-se a sociedade consumista como a composição de membros que possuem comportamentos influenciados por um estilo idealizado de existir. Corroborando ao que aborda Bauman, o autor Bittencourt (2011) explora que o consumo é uma atividade básica da condição existencial do ser humano, caracterizando pela busca por materiais simbólicos para a condição de existência. No entanto, ao extrapolar esse comportamento de manutenção da existência, caracteriza-se o consumismo. A partir disso, a sociedade consumista pode ser compreendida como um fator que reforça apenas um estilo de vida, excluindo as demais variações, iniciado ainda nos primeiros anos de vida.

No período conhecido como modernidade, a sociedade era construída e persuadida à obediência às normas e à conformidade, levando à existência de uma vida monótona e da idealização de amor pelo trabalho, e posterior a isso, na era pós-moderna, a sociedade consumidora exerce um caráter persuasivo, que surge desde à infância, extrapolando a perspectiva em que o foco de controle deixa de ser os corpos e passa ser a "administração do espírito" (BAUMAN, p. 42, 2007). Se na sociedade moderna o corpo era o objeto de uso para o controle social e o espirito administrado para se tornar vulnerável, na era pósmoderna, o objeto de controle é o espírito, para que o controle social parta de princípios intrínsecos, ou "de dentro para fora", agindo como controle social atrelado ao controle mercadológico. Com isso, Harari (2019), ao explorar o contexto de consumo através da história, aborda que na pré-moderna as relações de riquezas e gastos não estavam interligadas com o investimento em produção, uma vez que os mais ricos estavam mais interessados no gasto improdutível das riquezas e os mais pobres sobreviviam de estocagem.

Já na modernidade e pós-modernidade observa-se o oposto, os mais ricos necessitam movimentar suas riquezas através dos investimentos, e os mais pobres vivem em função dos gastos, em suma, por produtos ou serviços improdutíveis, alimentando a produção de produtos de vida curta, impulsionados pela indulgência. Freud (2011) compara a massa a um rebanho dócil, que necessita de um "senhor", um domador, pela necessidade de obediência e controle. Aliando a isso, Le Bon (1895) explica que uma multidão vai além de pessoas ocupando o mesmo espaço físico. A multidão compreende-se por indivíduos que, ao anularem a sua singularidade, passam a ocupar um mesmo plano psicológico no compartilhamento de ideais e comportamentos. Entende-se que a sociedade influenciada pelo consumismo pode ser comparada à domação de espírito, a partir de um possuidor que detenha o poder sob "um rebanho", que esteja à espera de um ser ou padrão que o influencie e o domine, compartilhando de um mesmo ideal.

Um dos grandes marcos da humanidade foi a transição do homem produtor para o homem consumidor. Bauman (2007) define a sociedade de produtores como uma fase "sólida" da modernidade, regida pela segurança. 0 objetivo era a construção de bens sólidos e seguros, que fossem duradouros e resistentes ao tempo. A ideia era "tamanho é poder". Sucedeu-se a era das grandes fábricas e dos exércitos de massa, assim como das estratégias de dominação com o intuito da manutenção da disciplina e da subordinação. Com as ideias de segurança e solidez, estudos postulados por Bittencourt (2011) abordam que na evolução do homem em sociedade pode-se transpor a nomenclatura homo sapiens para homo consumens, pois esse "novo" tipo de homem está focado no consumo assíduo de bens materiais que estejam facilmente ao seu alcance. Se antes o homem buscava pela solidez dos bens com o objetivo de fornecer segurança, atualmente, é justamente a ideia do fácil acesso e substituição que os conforta e os remete a sentimentos de sociabilidade e estabilidade.

Mas a transição dessa concepção da "sociedade dos produtores" para a nova configuração da sociedade, apresenta uma mudança extremamente significativa no comportamento e nos desejos do indivíduo. Bauman destaca que este ambiente existencial se tornou conhecido como "sociedade de consumidores" e distingue-se por uma reconstrução das relações humanas a partir do padrão, e a semelhança, das relações entre consumidores e os objetos de consumo (SILVA, 2011, p.2). 
Após a sociedade de produtores, surge o que viria a ser denominado por Bauman (2007) sociedade líquido-moderna de consumidores. Adotando os termos "cultura agorista" e "cultura apressada" caracterizados, principalmente, pela renegociação do significado do tempo. 0 tempo deixa de ser cíclico e linear como comumente se desenvolvia nas outras épocas e sociedades. Baudrillard (1970) relata que é preciso abandonar a concepção de que se vivencia a era da abundância, onde todas as necessidades podem ser saciadas com facilidade e exatidão, pois, quanto mais se produz mais se sublinha, distanciando-se do que seria a abastança. Vivencia-se uma sociedade consolidada pela exatidão do agora. As gerações passadas, enquanto o pêndulo direcionava à segurança, construíam seus ideais sob os alicerces de bases sólidas e duradouras. Atualmente, enquanto sociedade líquido-moderna, direciona-se os ideais à necessidade de liberdade e à satisfação imediatista e transmutável. Enquanto consumidores, tende-se a descartar e substituir pautados na sensação de imediatismo, pois sabe-se que algo surgirá para substituir e que haverá outras opções ao alcance.

\section{Mecanismos persuasivos utilizados na formulação de campanhas}

A partir do crescimento do mercado consumidor, Oliveira (2018) explica que a oferta cresce independente da demanda, onde o consumidor não necessitava esperar pela fabricação de um determinado produto. A variedade de mercado se consolida e as marcas são uma importante criação para personalização dos produtos e serviços, visando a diferenciação frente a inundação de demanda semelhante no mercado. Como ferramenta de divulgação, Gomes e Kury (2013) salientam que é na segunda metade do século XX em que o marketing inicia a sua funcionalidade nas empresas, possuindo o objetivo básico de promover, a partir da publicidade, as novidades do avanço tecnológico da época. Por se tratar de produtos inovadores, não existia o caráter competitivo, nem a necessidade de um determinado público-alvo; a simples divulgação era suficiente para despertar o interesse de compra. Chauvel (2001) citado por Santos (2008) destaca, ainda, que o cenário de ruptura do controle social sob o comércio fora fundamental para o aparecimento do marketing, pois rompendo a necessidade de organização social sob a produção, surge uma demanda crucial: a necessidade de um elo entre comerciantes e compradores.

Observa-se então que o marketing, embora atualmente tenha forte caráter persuasivo, surgiu com o objetivo da venda racional, a partir do pressuposto de informar o público sobre os produtos e serviços disponibilizados. Todavia, com as mudanças industriais e com as consequências apresentadas posterior às guerras, a demanda de mercado surge com uma demanda maior do que o necessário no mercado, manifestando a necessidade de se destacar frente ao mercado.Atem (2009) elenca que há quem acredite que o primeiro grande persuasor da história foi a serpente, ao levar Eva, no paraíso, a comer o fruto proibido, correlacionando-se a ideia apresentada por alguns publicitários de que o desejo já se encontra no indivíduo, e eles apenas os satisfazem.No entanto, o autor aborda que é no período moderno, com a expansão da demanda de bens de consumo e com a liberdade individual, em que em que a economia se volta para a valorização do indivíduo e a ideia de progresso, onde a publicidade aprece mais desinibida.

A partir da publicidade, sabe-se que existe muito mais por trás de uma informação do que ela aparenta. Guéguen (2010) aborda que, atualmente, as pesquisas sobre a cognição e o comportamento do consumidor tem o conhecimento de que não se processa as informações recebidas sem antes alterá-las. Compreendendo que a racionalidade no processo de informações é apenas um viés utópico. Leeuwen e Baaren (2016) exploram que diariamente somos bombardeados por informações que tentam nos influenciar em alguma tomada de decisão. E que, felizmente, não possuímos a capacidade cognitiva de processar todas as informações, todavia, mesmo com toda a demanda, algumas informações conseguem influenciar mais do que outras, na maior parte das vezes de forma inconsciente.

Segundo Ferreguet (2009) apud Febra (2016) a publicidade é considerada um espelho psicológico, pois utiliza as idealizações do público para elaborar suas campanhas. Explica ainda, que ao observar que deseja algo, o consumidor direciona seu comportamento e seu desejo à realização da "lacuna" existente. Compreende-se que enquanto seres sociais estamos predispostos a participar das multidões psicológicas e vulneráveis às influencias nas tomadas de decisão. No dia a dia, recebemos variados estímulos preenchidos de ideais utópicos, mas desejados, de estilo de vida, de comportamento e de consumo. Estando mergulhados em afazeres e em atividades, por vezes maçantes, busca-se por prazeres de fácil acesso e alcance, estando no ato da compra um grande escape para alcançar um prazer imediatista.0 que explicam Leeuwen e Baaren (2016) é que existem 3 principais vieses de necessidades explorados pelas campanhas publicitárias: necessidades sistêmicas, necessidades sociais e necessidades do eu.

As necessidades sistêmicas corresponde à carga genética mais primitiva da espécie, estando relacionada ao componente que está fora do controle pessoal. As campanhas utilizadas para atingir tal nível de 
necessidade, apresentam informações que são processadas antes mesmo de serem compreendidas e interpretadas, antes da informação se tornar inteligível. Nas necessidades sociais, carrega-se o caráter social na genética, correspondente a necessidade estar em convívio com outras pessoas, de aceitação e respeito, um dos aspectos mais explorados pelos publicitários. E a necessidade do eu, está interligada diretamente à saciedade das necessidades seja de segurança, de ter boa saúde ou uma boa renda, abordando, na publicidade, na forma de técnicas que projetem a ilusão de um futuro seguro e estável. Moderno (2000) aborda que a persuasão, nas campanhas publicitárias, é emitida através de componentes emotivos e inconscientes.

No âmbito emotivo, está relacionado aos sentimentos e emoções transmitidos com o objetivo de influenciar diretamente no comportamento de quem é atingido, sendo os estados emocionais voltados para a excitação e felicidade são os mais utilizados. Já na persuasão inconsciente há a influência dos instintos, sugestões e demais aspectos que transmitam a influência sedutora instigando desejos de posse. Componentes como apelo sexual, instinto de autoconservação, instinto de oposição, de poder e instinto material são utilizados.

\section{A influência das cores na percepção}

Dentre os sentidos utilizados no processo de persuasão a visão é imprescindível, pois através dela o público tem o primeiro impacto sob a peça de influência na tomada de decisão, sabendo disso, os publicitários utilizam a visão como uma importante ferramenta nesse processo. Fujisawa (2006) explica que a visão tem o objetivo de averiguar possíveis periculosidades no campo do indivíduo, é o instinto de morte sempre em alerta. No entanto, a visão também é responsável por captar tudo que está ao redor do receptor, e é nesse momento que cada componente vai ser fundamental para prender a atenção e influenciar no processo de persuasão.

Com isso, para Farina, Perez e Bastos (2006) a cor é considerada um importante componente no processo de consumo, por se tratar de um código universal, um conhecimento quase que hereditário. Se usada de forma estratégica, torna-se didática, de fácil compreensão, superando empecilhos idiomáticos. É através da coloração que o produto tem a sua primeira oportunidade para se destacar frente aos demais concorrentes, sobressair na percepção do consumidor, para depois o convencer ao ato da compra. As cores e a embalagem são os vendedores silenciosos.

Citando a cor que pode ser considerada o símbolo da publicidade, Heller (2014) classifica o vermelho como a mais utilizada na propagação de informação, mesmo que forma obsoleta. Nos anos de 1950, o vermelho era utilizado como símbolo da luta pela vida, com o passar do tempo, começou a ser usado como destaque no campo da publicidade. Porém, ao contrário do que se imagina, uma mensagem que está escrita em vermelha tem mais chances de ser ignorada do que uma que possui uma composição mais simples e textual e a explicação é simples: o vermelho foi tão explorado que se tornou obsoleto na percepção humana. Embora desperte a atenção do consumidor, são poucas as chances de ser consumida até o final. 0 vermelho ainda, dificilmente pode ser usado de forma criativa, o que ocasiona no tédio em imediato, a cor é o que é e entrega apenas isso.

Para Lam (2001) apud Palma (2013) as cores quentes, como o vermelho e amarelo, são mais propensas em agradar visualmente do que as cores frias, como azul e o violeta. A cor vermelha, no espectro das cores, é uma cor que está mais externa, sugerindo que seja o motivo para ser considerada uma cor que dispõe de maior atração visual. A cor é um componente fundamental na influência de escolha do consumidor, segundo estudos realizados para Revista do Jornal Expresso (2012) citado por Palma (2013), a cor é considerada a principal motivação que influencia na escolha de um produto (85\%). Sabendo disso, as marcas, no processo de divulgação, compreendem que uma escala de cor utilizada de forma assertiva, pode influenciar em $80 \%$ o percentual de vendas do determinado produto ou serviço.

As cores podem influenciar na percepção em relação ao tamanho e ao peso de uma estrutura, conforme afirma Heller (2014). Um exemplo é a cor preta, geralmente é associada a produtos e estruturas mais pesadas em comparação à cor branca. No entanto, essa manipulação ou associação possui uma explicação palpável. Caixas feitas de papelão são utilizadas para transportar objetos mais leves, devido a sua estrutura, em contrapartida, para transportar objetos mais pesados são utilizados, na maioria das vezes, caixas de madeira que possuem uma coloração mais densa. Antes de considerar que a cor pode ter caráter persuasivo, a experiência do alvo deve ser levada em consideração, no entanto, percebe-se que as cores podem transmitir sensações quando utilizadas associadas à contextos e sentimentos. 


\section{A interferência sonora no comportamento de consumo}

Após os recursos visuais, a audição é reconhecida como um significativo componente na tentativa de manipulação do comportamento de compra. Herter (2010) explica que a audição vem sendo utilizada principalmente na ambientação de lojas e supermercados. Constatou-se que a ambientação musical segue os componentes da dimensão física, emocional e de preferência, estando elas relacionadas ao volume, ritmo e velocidade, e a emocional e de preferência abrangem ao gosto e subjetividade do cliente. Cada segmento de mercado vai utilizar a musicalidade conforme o objetivo que espera alcançar, se desejam que o consumidor passe mais tempo na loja e, consequentemente, consuma mais, irão utilizar músicas mais lentas para gerar uma ambientação mais calma, se a loja possui um padrão alto dos produtos ofertados então investiram em músicas que remetam ao clássico e sofisticado.Para Guéguen (2010) a dimensão física da música, aliada ao contexto, influencia no comportamento desempenhado no ambiente e no consumo em si. Se os estabelecimentos buscam transmitir a ambientação do local através da música tocada, desejando que os clientes apresentem um comportamento mais calmo e com um nível de conversação menos barulhento, devem investir em música ambiente. No entanto, se desejam que os clientes fiquem agitados e consumam com maior rapidez, principalmente bebidas alcoólicas, devem buscar por músicas altas e que despertem a agitação psicomotora. Enquanto a preferência, Noth (1998) apud Guéguen (2010) constatou, através de estudos, que música clássica e o pop são os estilos que demandam maior influência positiva nos clientes, seja em relação as vendas ou na avaliação sobre o valor a ser pago. Inclusive, os donos de bares e boates possuem interesse em disponibilizar músicas em um ritmo mais rápido, porque nesse ambiente sonoro o consumo dos clientes é feito de maneira mais rápida e em maior volume.

Em um contexto diferenciado, Nittono e seus colaboradores (2000) apud Guéguen (2010) constataram que o desempenho durante o desenvolvimento de desenhos simples era compatível com o ritmo da música utilizada, se a melodia era mais lenta, levava um tempo maior, em contrapartida, se o ritmo era acelerado, o desenho levava menor tempo para ser finalizado. Em suma, compreende-se que as músicas sugestionam tanto no comportamento de compra quanto na conduta desempenhada pelo cliente, não se trata de uma ferramenta exata, e sim de uma variável experimentada e constatada que influência no desempenho de consumo exibido.

\section{Influência na tomada de decisão do consumidor}

Como na mitologia grega, em que Zeus adverte Narciso sobre o perigo em vislumbrar incansavelmente a sua imagem refletida na água, Key (1996) refere-se à publicidade como um espelho utópico de perfeccionismo. Na publicidade, a imagem e a mensagem, em suma, correspondem a um padrão ilusório de realidade, construído para propagar sensações positivas. Necessita-se desmitificar que a publicidade age conforme os interesses e bem-estar do consumidor, a divulgação publicitária possui um objetivo simples: persuadir ao comportamento de compra.

O consumidor, embora não saiba, não pensa por si mesmo. As pessoas tem a liberdade para consumir o que desejam, mas são livres para querer o que querem?Para Mlodinow (2013), o inconsciente é a estrutura fundamental dos seres vivos, uma vez que os organismos não humanos podem viver sem o consciente, é impossível viver sem o inconsciente. Enquanto a mente consciente processa algo entre dezesseis e cinquenta bits por segundo, a estrutura inconsciente armazena todas as informações que estão ocorrendo ao redor do receptor, sem que ele mesmo o perceba. Sabendo disso, a estrutura inconsciente é uma ferramenta explorada na elaboração de publicidades para a indução a um determinado comportamento ou conduta, sem que o receptor tenha consciência da motivação exata que o levou ao ato.

Para que uma peça publicitária desperte maior interesse na esfera consciente, o uso do apelo emocional é aplicado como manobra de associações psicológicas. Lopes (2015) aborda que a publicidade emocional busca transmitir a familiarização para o público, pois uma divulgação que apresente apenas aspectos racionais, será, em maioria, apenas informativa, não captando o interesse necessário para persuadir ao consumo. Nas divulgações realizadas, a base para a criação e o sucesso do induzimento está na capacidade de atingir os possíveis desejos do consumidor. Para isso, os marketeiros e publicitários, investigam meios de atingir as necessidades existentes, projetos ideias, irreais, mas sonhados por quem é atingido. 
Conforme cita Machado et al. (2002), o objetivo central das mensagens subliminares é a manipulação psíquica de quem as percebem. A manipulação é feita através de inserção de imagens, palavras ou ideias que não podem ser identificadas conscientemente pelo consumidor, anulando a possibilidade de escolha de aceitar ou rejeitar. Influenciando na tomada de decisão, resultando no consumo para a satisfação de uma necessidade incompreendida.

Segundo Key (1996), as estratégias subliminares são divididas em seis técnicas. Na inversão de figura/fundo, distingue-se a figura e o fundo, enquanto a atenção consciente foca na figura, a inconsciente capta todos os elementos do fundo. No embutimento de imagens, são adicionados enxertos às propagandas, ou seja, inserção de imagens ou formas pelo uso de luz e sombra ou pela substituição de formas e contornos. No duplo sentido é trabalhado a ambiguidade da mensagem, geralmente correlacionado com aspectos sexuais. A projeção taquistoscópica, ocorre a partir da projeção de flashes em telas de cinema ou mesa de luz para projetar imagens e palavras em alta velocidade, imperceptíveis à nível consciente. Na luz de baixa intensidade e som de baixo volume, utiliza-se a inserção de palavras imperceptíveis ao olho nu, sendo a palavra sex (sexo) muito utilizada. A iluminação e som de fundo é comumente empregada em filmes, buscando reforçar as informações processadas conscientemente, e sempre que invadem a percepção consciente, agem como distração, prejudicando a percepção.

Com isso, Abreu (2017) explica que as mensagens subliminares são responsáveis pela indução de comportamentos e na interferência das decisões inconscientemente do público-alvo, pois tudo que não é processado de forma perceptível pelo homem, se armazena no nível inconsciente, podendo permanecer a vida toda. Sem dúvidas, uma técnica que tira todo poder decisório de quem executa o comportamento induzido.

Para Key (1996), o homem enquanto telespectador e alvo da publicidade manipulativa, não pensa por si mesmo, apenas reflete em seu comportamento o que é induzido pelas técnicas subliminares. Cita que os comportamentos impulsivos como fome, sede, necessidades sexuais e de conforto e desejo de maternidade são os mais atingidos pelas técnicas subliminares. Embora os impulsos, quando expostos às mensagens, tenham origem nesses estímulos externos, não são percebidos de tal forma, e sendo interpretados oriundo de componente interno.

Utiliza-se em grande parte, a associação dos comportamentos impulsivos, como fome e necessidades sexuais, pois estão conectados no cérebro. A velocidade é um importante aspecto pensado na formulação da publicidade, realizando a divisão: maior quantidade de informação por menor tempo de exposição. Para contornar o efeito da mensagem subliminar, os consumidores necessitam treinar a capacidade de análise da peça publicitária, a partir do relaxamento da consciência e ampliando a exposição à mensagem.

Brussio (2017) relata que é na concepção de arquétipo que se observa a construção de padrões, sendo esse, concebido com o objetivo de referenciar um modelo de algo material ou imaterial. Enquanto sociedade, observa-se a existência de diversos padrões pré-estabelecidos, e os consumidores, enquanto rebanho, como compara Freud (2011), os acompanha, em diversos momentos, sem compreender de fato o que os motiva, e nesse momento, visualiza-se a ação do inconsciente coletivo. A persuasão é canalizada principalmente através do uso de símbolos, a priori, já existentes na hereditariedade inconsciente, relacionados a impulsos comportamentais, atrelado à necessidades intrínsecas. Embora o consumo seja de caráter individual, o consumidor necessita pertencer à sociedade, e utiliza do consumo para isso.

Em síntese, o uso das técnicas subliminares na propagação de comportamentos de consumo, possui como limite apenas a criatividade humana. Conforme afirma Calazans (1992), diariamente novas técnicas são descobertas e usadas, além de aperfeiçoamento das manobras já existentes, em uma infinidade de possibilidades, seja através de áudios, imagens, vídeos, cores, abrangendo todos os sentidos. As tecnologias que surgem já são concebidas como componente subliminar. As empresas multinacionais investem, em diversas mídias, mensagens que propagem o consumo de seus serviços e produtos, tudo de forma subliminar.

\section{Recursos emocionais na influência de escolha do cliente}

Bragaglia (2013) define como enganosa toda publicidade que assemelhe o consumo a uma espécie de fetiche, associando estados emocionais ou sentimentos ao consumo. A associação fantasiosa que constrói em sua divulgação, não possui nenhuma relação com o resultado do uso imediato do produto ou à função para qual foi desenvolvido. 
Na sociedade de consumo, como explicam Souza e Lima (2012), o público anseia pela personalização dos produtos e serviços através de símbolos e histórias que proporcionem humanização. Utilizar-se de ferramentas de pesquisas de mercado se tornou obsoleto. A contemporaneidade necessita que a cultura esteja intrínseca em cada serviço, os consumidores necessitam criar um elo entre o produto e sua necessidade, e através disso a persuasão é realizada.

Para o autor Bragaglia (2014), o consumidor, cada vez mais, busca pelo preenchimento emocional a partir do consumo. Com isso, os profissionais da área estão investindo na construção de estórias e na disseminação de estados emocionais que nada têm haver de fato com o desempenho do que é ofertado. Esse processo de assimilação ocorre através dos mecanismos de identificação e de projeção. Na identificação o consumidor busca por aspectos que remetam certa familiaridade com sua história de vida. A projeção, seguindo a formulação psicológica, trata-se de transpor aspectos próprios para uma outra pessoa ou objeto, no consumo está relacionado à ideia de que ao adquirir o que é divulgado, obtenha-se a sensação ou estado emotivo propagado.

Levy (1959) apud Miranda, Pepece e Mello (2015) elenca que um consumidor, ao ser persuadido por uma divulgação, não está apenas buscando o que o serviço ou produto pode lhe proporcionar, mais do que isso, ele busca, atrelado a esse consumo, por significados pessoais e coletivos que o ato lhe proporcionará. 0 jogo simbólico perpassa não somente pela influência da carga inconsciente, seja coletiva ou particular, mas ainda, pelo o que esse símbolo pode representar enquanto componente social. Cada indivíduo vai processar os conceitos de forma individual, mas com uma mesma carga de compartilhamento simbólico seja de origem inconsciente seja quando situados em um mesmo grupo social.

As respostas comportamentais apresentam maior eficácia quando existe uma conexão emocional. Segundo Hamid (2013), os consumidores dispõem de maior atenção quando apresentam um elo entre si e a marca ou produto. Sabendo disso, a divulgação é desenvolvida com base no desenvolvimento de conexões, através de mecanismos profundos que despertem a autorrealização, significado existencial ou crenças pessoais e culturais. Com isso, existem três técnicas utilizadas no marketing para a relação afetiva entre produto e consumidor: o condicionamento clássico, o afeto para com a publicidade, e a mera exposição.

$\mathrm{Na}$ publicidade, a partir do condicionamento clássico, unido o produto que será divulgado (estímulo condicionado) junto de uma imagem apelativa e um componente que evoca a resposta emocional positiva (estímulo incondicionado), o afeto tem papel fundamental na relação de consumo, principalmente quando os produtos não são familiares aos consumidores, e a exposição, baseia-se no pressuposto de que o público tende a gostar de um determinado objeto quando criam a familiarização.

McCracken (1990) explana que a elaboração de personificação em torno de produtos e serviços, resulta em uma construção de vida baseada na busca por transferências de significações, no entanto, sem êxito, gerando o sentimento de fracasso tanto individualmente quanto coletivamente. Torna-se um ciclo pela busca por resultados e padrões inexistentes. Essa inconstante e incansável busca atrela-se ao anseio pela necessidade de pertencer ao um grupo social, executar um comportamento que remeta a sensações positivas ou a obtenção de um status social. 0 consumidor torna-se escravo de uma engrenagem que vende, não somente um item "utilitário", mas que também, propaga o ideal de que ele apenas atingirá estados emocionais satisfatórios se existir enquanto membro ativo do consumo.

\section{CONSIDERAÇÕES FINAIS}

Ao chegarmos no final deste trabalho, consideramos que ele apresenta uma tentativa de compreensão de como o mercado utiliza os estudos psicológicos na formulação de suas campanhas para influenciar à tomada de decisão, embora compreenda que a temática apresenta reflexões que devam ser aprofundadas futuramente. No entanto, consideramos que os objetivos elaborados para o desenvolvimento do trabalho foram abordados e alcançados.0 mercado e suas demandas consumistas, que estão em constante crescimento e competitividade, empenham-se no uso de técnicas que manipulem o comportamento do público-alvo, influenciando no poder de livre escolha, sem que o consumidor tenha conhecimento da intervenção. 0 processo de divulgação vai além da propagação de produtos e serviços, busca-se a interferência a nível inconsciente do que se consome. Nenhum elemento é inserido em vão; as cores, os sons, o jogo de luzes, a entonação dos anunciantes. Todo elemento possui uma função significativa: persuadir ao comportamento de compra.

Acredita-se que os objetivos postulados foram alcançados, a partir da metodologia escolhida, embora seja importante ressaltar a escassez de material sobre a temática, principalmente no idioma português, visto que a publicidade está em todos os lugares, influenciando nossos comportamentos e o direito de querer o 
que desejamos de fato.Faz-se necessário analisar e compreender a relação entre sociedade e consumo. Para isso, devemos contemplar as ações enquanto ser atuante na sociedade e identificar o que verdadeiramente significada cada consumir, cada produto adquirido de forma supérflua, além de analisar de forma crítica os limiares éticos na influência de escolha do consumidor. Para assim, desligarmos o automático, que agora compreendemos que não se trata de um automático, mas da interferência mercadológica em nossos comportamentos e psique.

Observando a escassez de material que aborde as temáticas reunidas neste trabalho, é sugerido maior atenção cientifica para área da psicologia do consumidor, por ser tratar de um âmbito de estudo que atinge toda a sociedade enquanto comportamento universal. Ao elaborar estudos que abordem o uso dos componentes emocionais e das mensagens subliminares nas formulações de campanhas de divulgação, atua na prevenção do consumo compulsivo, assim como proporciona a possibilidade de elaborar estratégias mais assertivas, que tanto satisfaçam a engrenagem do mercado quanto deixem claro para o público os seus verdadeiros objetivos e intenções.

\section{REFERÊNCIAS}

[1] ABREU, C. M. DE. Publicidade: responsabilidade civil nas relações de consumo. Revista Vianna Sapiens, v. 7, n. 1, p. 28, 8 nov. 2017.

[2] AMON, D; GUARESHI, P., A; ROSO, A; VARONESE, M. Psicologia Social e comunicação publicitária: uma análise crítica. Ciências Sociais Unisinos, v. 46, n. 2, p.178-186, maio/agosto 2010.

[3] ATAÍDE, GLAUBER. Publicidade e Psicanálise. IFD Comunicação. Brasil, 24, janeiro de 2011.

[4] ATEM, Guilherme N. Persuadere: uma história social da propaganda. In: MACHADO, M.B. (Org.). Publicidade e Propaganda: 200 anos de história no Brasil. Novo Hamburgo: Feevale, 2009.

[5] BAUDRILLARD, JEAN. A sociedade de consumo. Lisboa: Editions Planete, 1970.

[6] BAUMAN, Z. Vida para consumo. Rio de Janeiro: Zahar Ed., 2007.

[7] BITTENCOURT, R. N. Os dispositivos existenciais do consumismo. Revista Espaço Acadêmico, v. 10, n. 118, p. 103-113, 6 dez. 2011.

[8] BRAGAGLIA, Ana Paula. Publicidade excludente e suas implicações éticas. Observatório da Imprensa, v. 749, n. 772, 2013.

[9] BRAGAGLIA, Ana Paula. Publicidade excludente e outros apelos emocionais: reforçando o estereótipo "feliz é quem consome". Verso e Reverso, São Leopoldo, v. 28, n. 67, p. 2-14, 2014.

[10] BRANDT, J., A. Psicanálise de Freud Explicada. São Paulo: Zagodoni, 2018.

[11] BRUSSIO, J.; B. Um estudo sociológico da moda sob o arquétipo do consumo obsoleto. UFMA (Universidade Federal do Maranhão), 2017.

[12] CALAZANS, F. Propaganda subliminar multimídia. Rio de Janeiro: Summus Editorial, 1992.

[13] COSTA, M., F.; PATRIOTA, A., L., M.; ANGELO, C., F. Propagandas de apelo emocional e utilitário: efeitos na atitude do consumidor e na percepção do brand equity de um celular Samsung. Universidade Federal de Pernambuco, Recife, 2017.

[14] CREPALDI, LIDELI. A publicidade no divã: análise psicanalítica dos anúncios televisivos da Chevrolet. In: Congresso Brasileiro de Ciências da Comunicação, n. 28, 2005, Rio de Janeiro. Anais -São Paulo: Intercom, 2005.

[15] CUNHA, L.D.; SAUERBRONN, J.F.R. Um experimento sobre o efeito de apelos sexuais em propagandas reais de cerveja sobre aintenção de compra e atitude frente à propaganda de jovens adultos. Sociedade Contabilidade e Gestão,v. 8; n. 3, 2013.

[16] FARINA, M.; PEREZ, C.; BASTOS, D. Psicodinâmica das cores em comunicação. São Paulo: Editora Edgard, 2006.

[17] FEBRA, R. S. P. Técnicas Persuasivas na publicidade- o destaque à nacionalidade. Porto: s.n., 2016.

[18] FONTENELLE, I., A. Psicologia e marketing: da parceria à crítica. Arquivos Brasileiros de Psicologia, v. 60, n. 2, 2008.

[19] FONSECA, J. J. S. Metodologia da Pesquisa Científica. Fortaleza: UEC, 2002. 
[20] FREUD, S. Psicologia das Massas, Análise do Eu e Outros Textos (1920-1923). Obras Completas Volume 15. São Paulo: Companhia das Letras, 2011.

[21] FROHLICH, E., R.; DORNELES, S., B., B. Elaboração de Monografia na Área de Desenvolvimento Rural. Universidade Aberta do Brasil - UAB/UFRGS - Porto Alegre; Editora da UFRGS, 2011.

[22] FUJISAWA, Marie Suzuki. A exploração dos cinco sentidos como forma de persuasão e estímulos ao consumo. Comunicação \& Inovação, v. 7, n. 13 p. 30-38, São Paulo, 2006.

[23] GERHARDT, T., E.; SILVEIRA, D., T. Métodos de Pesquisa. Porto Alegre: Editora da UFRGS, 2009.

[24] GOMES, M.; KURY, G. A Evolução do Marketing para o Marketing3.0: O Marketing de Causa. In: XV Congresso de Ciências da Comunicação na Região Nordeste -Mossoró -RN -2013 Disponível em: http://portalintercom.org.br/anais/nordeste2013/resumos/R37-0945-1.pdf. Acesso em: 22 nov. 2019.

[25] GUAZZELLI, D. A. Código de Defesa do Consumidor: o direito do cidadão alicerçado na informação. Organicom, São Paulo, v. 7, n. 12, 2010.

[26] GUÉGUEN, NICOLAS. Psicologia do consumidor: para compreender melhor de que maneira você é influenciando. São Paulo: Editora Senac, 2010.

[27] GUSTAVO LE BON. Psicologia das multidões. Presses Universitaires de France, 1895.

[28] HAMID, FATIMA. O efeito dos estados de espírito e emoções na publicidade: o caso Ikea. IADE-U Instituto de Arte, Design e Empresa, 2013.

[29] HARARI, Y. N. Sapiens - Uma Breve História da Humanidade. 45. ed. Porto

[30] Alegre, RS: L\&PM, 2019.

[31] HELLER, EVA. A psicologia das cores: Como as cores afetam a emoção. Editorial Gustavo Gili, Barcelona, 2014.

[32] HERTER, Márcia Mauro. O efeito da música nas intenções de comportamento do consumidor. Porto Alegre, 2010. Universidade Federal do Rio Grande do Sul. 2010.

[33] HUERTAS, Melby Karina Zúñiga. Atitude do consumidor frente à propaganda: um estudo sobre os apelos racionais e emocionais da propaganda na indústria farmacêutica. 2005. Tese (Doutorado em Administração) - Faculdade de Economia, Administração e Contabilidade, Universidade de São Paulo, São Paulo, 2005.

[34] JUNIOR, R., F. Limiar: uma visão publicitária sobre os limites da percepção. Universidade de São Paulo: Escola de Comunicações e Arte, 2009.

[35] JUSTO, C., S., P., B.; MASSIMI, M. Contribuições da Psicologia para Área do Marketing e do Conceito de Consumidor: Uma Perspectiva Histórica. Revista Psicologia e Saúde, v. 9, n. 2, p. 107 120, maio/ago. 2017.

[36] KEY, W., B. A era da manipulação. 2 ed. São Paulo: Scritta, 1996.

[37] LE BON, GUSTAVE. Psicologia das multidões. Pensadores Delraux, 1895.

[38] LEEUWEN, A., V; BAAREN, V. Persuasão na publicidade: 33 técnicas psicológicas de convencer. São Paulo: Gustavo Gili, 2016.

[39] LOPES, M., C., C., F. A importância da publicidade emocional no marketing viral. Viseu, 2015.

[40] MACHADO, D., C; MAGRON, M., L., R; SILVA, S., N., P. Mensagem subliminar - Um mergulho no inconsciente humano. Congresso Brasileiro de Ciências da Comunicação. XXV. Salvador/BA. Anais... 2002. Disponível em: http://publica.fesppr.br/index.php/publica/article/download/140/41. Acesso em: 21 nov. 2020.

[41] MCCRACKEN, G.; D. Culture and Consumption: New approaches to the symbolic character of consumer. Indiana University Press, 1990

[42] MIRANDA, A. P. C.; PÉPECE, O. M. C. Existe mais entre o consumidor e suas posses do que supõe a nossa vã filosofia: Uma revisão crítica sobre o consumo simbólico. Congresso nacional de ciências da comunicação, 2000, Manaus. Anais... Manaus: Intercom, 2000. Disponível em: http://www.portcom.intercom.org.br/pdfs/c8975d022a1511f57e777d3bdab9676a.pdf. Acesso em: 21 nov. 2020. 
[43] MLODINOW, L. Subliminar: como o inconsciente influencia nossas vidas. Rio de Janeiro: Zahar, 2013.

[44] MODERNO, M.; C.; S. Mecanismos psicológicos da publicidade e do marketing. Millennium, 2000.

[45] MUNIZ, E. Publicidade e propaganda - origens históricas. Caderno Universitário, n.148. Canoas: ULBRA, 2004.

[46] NERY, M., B., M.; MENÊSES, C., S.; TORRES, T., K., S. Um breve ensaio da psicologia acerca do comportamento consumista na sociedade atual. Interfaces Científicas - Humanas e Sociais, Aracaju, v.01, n.01, p. 53-62, out. 2012.

[47] NERY, V. C. A.; SILVA, N. C. Propaganda subliminar: Um estudo sobre a sua interpretação. OPSIS, v. 7, n. 8, p. 217-232, 31 mar. 2007.

[48] OLIVEIRA, Mario Cesar Pereira. Apontamentos sobre a História da Publicidade Mundial. In: Sociedade Brasileira de Estudos Interdisciplinares da Comunicação. 92(Intercom) 41ํㅜ Congresso Brasileiro de Ciências da Comunicação, 2018, Joinville, SC. Anais (online). Disponível em http://portalintercom.org.br/anais/nacional2018/resumos/R13-1974-1.pdf Acesso em: 21 nov. 2019.

[49] PALMA, I.; M. A cor e a publicidade. Instituto Superior de Ciências Sociais e Políticas da Universidade Técnica de Lisboa, 2013.

[50] PAIXÃO, M., V. A influência do consumidor nas decisões de marketing. Curitiba: Ibpex, 2012.

[51] PULLINO, J. O lado oculto da comunicação publicitária: as mensagens ocultas e subliminares e a ilicitude de seus efeitos sobre o consumidor. [S.I.], 2016.

[52] CURTIS, A. The Century of the self. USA: British Broadcasting Corporation, 2002.

[53] SANTOS, D. Fidelização de Clientes. 2008.

[54] SAUERBRONN, J. F. R.; AYROSA, E. A. T.; BARROS, D. F. Bases sociais das emoções do consumidor uma abordagem complementar sobre emoções e consumo. Cadernos EBAPE.BR, v. 7, n. 1, art. 11, p. 169$182,2009$.

[55] SILVA, André. A Sociedade Contemporânea: A Visão de Zygmunt Bauman. Revista Nexi, 2012. Universidade Católica de São Paulo. 2011.

[56] SILVA, A., B., B. Mentes consumistas: do consumismo à compulsão por compras. - São Paulo: Globo, 2014.

[57] SOUZA, L., P.; LIMA, M., Y., G. A influência dos arquétipos na sociedade de consumo. VIII ENPECOM, 2012. Disponível em:

https://eventos.ufpr.br/enpecom/enpecom2016/paper/downloadSuppFile/289/71. Acesso em: 21 nov. 2020

[58] ZIMERMAN, David E. Fundamentos psicanalíticos: teórica, técnica e clínica: uma abordagem didática. Porto Alegre: Artmed, 2007. 


\section{Capítulo 6}

\section{A contribuição da psicologia do esporte para a qualidade de vida do idoso}

\section{Gíbia Ribeiro Messias}

Resumo: 0 envelhecimento é uma fase com limitações para qualquer indivíduo, e a Psicologia do Esporte tem se dedicado a desenvolver práticas que possam contribuir para a diminuição dessas limitações. Este trabalho tem por objetivo compreender as contribuições da Psicologia do Esporte para a qualidade de vida do idoso. 0 tipo de pesquisa utilizado foi a pesquisa bibliográfica qualitativa e sistemática. Para esta pesquisa foram utilizados livros encontrados na biblioteca da FAMETRO, bem como trabalhos acadêmicos encontrados nas plataformas SCIELO e Google Acadêmico. Com base na pesquisa foi possível observar que a população idosa tem crescido cada vez mais, e que é um público que não tem o hábito de praticar atividades físicas, por isso tem vivido o envelhecimento com dificuldades, percebidas tanto física quanto psicologicamente. A Psicologia do esporte tem se mostrado eficaz pois baseia sua intervenção terapêutica em atividades físicas, o que gera importantes contribuições para a qualidade de vida do idoso, pois estimula funções cognitivas relevantes, como a memória e a linguagem; e gera menor risco para doenças cardiovasculares, doenças crônicas, além de menor incidência à ansiedade, depressão, etc. Este trabalho, portanto, contribuiu com uma nova pesquisa acadêmica voltada para a área, além de beneficiar a sociedade como um todo, que tem necessidade de propostas de intervenção terapêuticas que possam assistir aos idosos.

Palavras-Chave: Psicologia; esporte; qualidade de vida; idoso; contribuições. 


\section{INTRODUÇÃO}

A velhice não pode ser definida por critérios únicos, pois são diversos os fatores que influenciam na idade de um determinado indivíduo. 0 idoso é aquele que tem várias idades: a idade do corpo, da sua história genética, da sua parte psicológica e da sua ligação com a sociedade (ZIMERMAN, 2000).

Ou seja, para se falar em qualidade de vida para o idoso, deve-se adotar múltiplos critérios de caráter biológico, psicológico e sociocultural. Vários elementos são determinantes ou indicadores de qualidade de vida na velhice: saúde biológica, satisfação, controle cognitivo, competência social, produtividade, atividade física, eficácia cognitivo, status social, renda, continuidade de papéis familiares e ocupacionais e continuidade de relações informais em grupos primários (NERI, 2009).

Além disso, a Psicologia do Esporte, é a ciência que estuda a relação entre o esporte, tanto profissional, como amador (o que inclui as atividades físicas simples), e o bem-estar da pessoa a que se aplica tal ciência, no caso desta pesquisa, o público alvo foi o idoso. "O psicólogo do esporte estuda, identifica e compreende teorias e técnicas psicológicas que podem ser aplicadas ao contexto do esporte e do exercício físico" (PINHO, 2016, p. 37). Para esta pesquisa, tratamos do elemento atividade física como promotor de qualidade de vida durante a velhice, tema que, na ciência psicológica, é investigado pela Psicologia do Esporte

Por isso, a partir da necessidade de se trabalhar os problemas do envelhecimento, foi proposto como objetivo geral compreender as contribuições da Psicologia do Esporte para a qualidade de vida do idoso. Para isto, foram propostos como objetivos específicos: a) estudar as condições físicas e psicológicas do idoso brasileiro; b) levantar as atividades desenvolvidas pela Psicologia do Esporte para a melhoria da qualidade de vida da pessoa idosa e; c) discutir sobre os benefícios oferecidos pela Psicologia do Esporte para a qualidade de vida do idoso.

Portanto, falar de envelhecimento é falar de um tema extremamente contextual, visto que todos chegaremos a essa etapa do ciclo da vida. Pensar sobre o idoso, é pensar na discussão aplicando para a nossa realidade, pois todos temos um idoso na família ou próximos a nós. Por isso a visibilidade para este tema ser tão necessária.

Além disso, a população idosa tem crescido significativamente, no decorrer dos anos. Também é um público que merece uma atenção especial, pois passa por essa etapa com muitas dificuldades, limitações, concomitantemente com doenças próprias da idade, dentre muitos outros fatores que fazem com que a velhice seja uma etapa delicada da vida humana.

Por isso, a presente pesquisa vem contribuir para que a sociedade possa contar com novas pesquisas capazes de dar suporte aos indivíduos nesta etapa da vida, cujas limitações se tornam marcantes e geram problemas. Além disso, esta pesquisa traz para a sociedade a possibilidade de novas atividades e implementações dentro de políticas públicas voltadas para a população, que cada vez mais tem necessitado de um olhar humanizado para os grupos sociais.

Além disso, quanto ao âmbito acadêmico, ainda são poucos os trabalhos de pesquisa realizados sobre o tema, visto que houve certa dificuldade de se encontrar bibliografias que tratem do assunto. 0 que tornou este trabalho extremamente importante para o enriquecimento da pesquisa em Psicologia do Esporte, pois agrega conhecimento na área, trazendo novas informações a respeito do tema, haja visto que este é um ramo das ciências psicológicas que ainda é muito novo, se levarmos em consideração os anos de surgimento da Psicologia e precisa de uma quantidade maior de trabalhos voltados para a área.

\section{REFERENCIAL TEÓRICO}

\section{0 envelhecimento}

A velhice é uma etapa da vida com características e necessidades específicas, o que exige dos profissionais da saúde, em geral, técnicas de intervenções direcionadas à pessoa idosa, partindo do reconhecimento de suas próprias manifestações emocionais conscientes e inconscientes (EIZERIK et al, 2007).

A compreensão do processo de envelhecimento humano não requer apenas o entendimento da palavra na concepção linguística do termo, do qual podemos dizer que envelhecer é chegar pouco a pouco a um período mais avançado da vida ou, perder a jovialidade, a beleza, além das significativas perdas das habilidades cognitivas. [...] 0 processo de envelhecimento humano deveria considerar o estudo de diversas variáveis presentes na vida dos indivíduos 
como: biológicos, físicos, econômicos, familiares e, principalmente, pessoais e socioculturais (DÁTILO; CORDEIRO, 2015, p. 19).

Além disso, na velhice, a estrutura sináptica do cérebro, torna-se menos densa e menos eficiente, o que resulta na desaceleração gradativa da velocidade das sinapses, o que gera um retardamento no tempo de reação em várias tarefas diárias (BEE, 2001).

Atividades como escrever, amarrar os sapatos, levam mais tempo. Adaptar-se às mudanças de temperatura ou iluminação, também levam mais tempo. Até mesmo atividades que envolvam palavras, que geralmente mostram pouca mudança com a idade, ainda assim são realizadas de maneira mais lenta (BEE, 2001).

Ou seja, não existe um parâmetro para se definir ou medir o envelhecimento, ele é variável e único a cada indivíduo. E cada ser humano vive este ciclo da vida, de maneira única, pois todas as suas experiências, hábitos, aprendizados, emoções, e todas as suas relações interpessoais vão definir, direta ou indiretamente, como será o processo de envelhecimento em sua vida.

Entretanto, o que se pode afirmar, com certeza, é que o envelhecimento chega para todo e qualquer indivíduo, e traz consigo mudanças físicas e psicológicas que marcam esta fase. 0 que exige uma assistência profissional, no decorrer desse processo, afim de que o ciclo se torne menos radical e sofrível, o possível.

Além disso, "verifica-se um progressivo envelhecimento da população, produzido pela coexistência dos progressos da medicina com a crescente redução das taxas de natalidade" (EIZERIK et al., 2007, p. 170).

"A população global está envelhecendo. Em 2008, quase 56 milhões de pessoas no mundo tinham 65 anos ou mais, o incremento anual liquido é de mais de 870 mil por mês. Até 2040 , projeta-se uma população total dessa faixa etária de 1,3 bilhão. Estima-se que em 10 anos pessoas com 65 anos ou mais pela primeira vez estarão em maior número que crianças de 5 anos ou menos" (PAPALIA; FELDMAN, 2013, p. 572).

Em contrapartida, "há uma escassez de profissionais devidamente treinados na área de saúde mental que possa atender os idosos, e essa escassez provavelmente aumentará na mesma proporção que a estimativa de aumento da população mais velha" (PAPALIA; FELDMAN, 2013, p. 589).

O que demanda da ciência, a necessidade de novas pesquisas e estudos que possam atender ao público idoso, além de técnicas de intervenção na área da saúde mental que atendam à essa necessidade. E exige do mercado, profissionais preparados em todas as áreas da saúde física e mental, para o atendimento a este público que tem aumentado.

\section{O esporte e a qualidade de vida na terceira idade}

Vários estudos identificaram três componentes principais do envelhecimento bem-sucedido: (1) anulação da doença ou de incapacidade relacionada à doença, (2) manutenção elevada das funções psicológica e cognitiva e (3) engajamento constante e ativo em atividades sociais e produtivas. Os idosos bem-sucedidos tendem a ter apoio social, emocional e material, o que contribui para saúde mental; e enquanto permanecem ativos e produtivos não se consideram velhos (PAPALIA; FELDMAN, 2013, p. 611).

Ter qualidade de vida, não implica apenas nas variáveis orgânicas, mas é estar bem em todos os aspectos da vida, de forma global, sendo eles: pessoal, familiar, social e profissional (SILVA, 2009). Portanto, qualidade de vida é um tema complexo, abstrato, subjetivo, com diferentes aspectos, sem definição consensual que atualmente tem tido ampla importância atualmente (CAMBOIM et al, 2017).

Percebe-se que os idosos que possuem incapacitações físicas que o impedem de realizar atividades físicas regulares, apresentam uma maior propensão ao declínio mais acelerado em várias funções físicas ou mentais, devido à carência de atividades físicas (BEE, 2001). "Mesmo entre adultos mais idosos que vivem com escassez de recursos, cujo risco genérico de saúde deficiente é elevado, os hábitos individuais de saúde estão relacionados à doença" (BEE, 2001, p. 543). Além disso, os idosos que se sentem doentes ou incapacitados estão menos direcionados à atividade física, sendo eles exatamente os mais propensos à hospitalização (BEE, 2001). 
Considera-se que variável mais significativa seja o exercício físico, sendo associado não apenas à longevidade, como também à melhor manutenção das várias funções físicas (BEE, 2001, p. 543). "Estudos em nível mundial demonstram o perfil da população inativa fisicamente como sendo mais prevalente em mulheres, idosos, indivíduos de baixo nível socioeconômico e escolaridade" (MACIEL, 2010, p. 1027).

"Mais do que qualquer coisa, o exercício físico parece ser até mesmo mais importante nos anos posteriores, do que em estágios anteriores. Quando se é jovem, você lida com o sedentarismo. Seu corpo irá funcionar com eficiência, mesmo que você negligencie" (BEE, 2001, p. 543).

Quanto aos benefícios, pode-se afirmar que "o exercício regular pode fortalecer o coração e os pulmões e diminuir o estresse [...] Além disso, pode melhorar o estado de alerta mental e o desempenho cognitivo, aliviar a ansiedade e a depressão moderada e promover sentimentos de controle e bem-estar" (PAPALIA; FELDMAN, 2013, p. 588).

\section{Psicologia do esporte}

A Psicologia do Esporte é uma área da Psicologia que vem ganhando espaço ao longo dos anos. "Em 1985 foi reconhecida como um campo da Psicologia e teve sua disciplina específica sendo ofertada pelas primeiras vezes em algumas universidades brasileiras no final da década de 90. Em 2007 foi reconhecida pelo Conselho Federal de Psicologia como especialidade do psicólogo" (PINHO, 2016, p. 1).

Além disso, "a Psicologia do Esporte integra a investigação, a consultoria clínica, a educação e atividades práticas programadas associadas à compreensão, à explicação e à influência de comportamentos de indivíduos e de grupos que estejam envolvidos em esporte de alta competição, esporte recreativo, exercício físico e outras atividades" (VIEIRA et al, 2010, p 392).

O psicólogo do esporte estuda, identifica e compreende teorias e técnicas psicológicas que podem ser aplicadas ao contexto do esporte e do exercício físico, tanto em nível individual - o atleta ou indivíduo praticante - como grupal - equipes esportivas ou de praticantes de atividade física. Sua atuação é tanto diagnóstica, desenvolvendo e aplicando instrumentos para determinação de perfil individual e coletivo, capacidade motora e cognitiva voltada para a prática esportiva, quanto interventiva atuando diretamente na transformação de padrões de comportamento que interferem na prática da atividade física regular e/ou competitiva (PINHO, 2016, p. 37).

0 conceito de Psicologia do Esporte pode variar de acordo com a finalidade à qual se aplica a ciência, ou seja, não existe um conceito fechado para a mesma. Além disso, as áreas de atuação são inúmeras e atendem aos mais variados públicos. Entretanto, essa amplitude de conceitos e técnicas reforçam a importância dessa ciência para a sociedade, e implica também na necessidade cada vez maior, de estudos e pesquisas que possam dar base a essa área da Psicologia.

Pois "a prática desportiva pode servir como uma forma de estimulação tanto como social e física, mas também emocional. A promoção de hábitos que possam ser realizados de maneira saudável pode ser instrumento para a diminuição de afetos negativos, como angústia, estresse, hipertensão, entre outros" (PINHO, 2016, p. 18).

O esporte recreativo: que visa o bem-estar e aumento de qualidade de vida para todas as pessoas. É praticado de maneira voluntária e com conexões com os movimentos de educação permanente e com a saúde. 0 psicólogo, nesse caso, atua na primeira linha de análise do comportamento recreativo de diferentes faixas etárias, classes sócias econômicas e atuações profissionais em relação a diversos motivos, interesses e atitudes (PINHO, 2016, p. 8).

Além disso, "o exercício físico somado a outros tipos de tratamento para pessoas com doenças mentais graves pode aliviar diversos sintomas psicológicos secundários, como baixa autoestima e auto eficácia, além do isolamento social elevado" (RICHARDSON et al, 2005, apud PINHO, 2016, p. 19).

\section{PROCEDIMENTOS METODOLÓGICOS}

Como método de investigação desta pesquisa, optou-se por utilizar a pesquisa bibliográfica sistemática e qualitativa, que se utiliza de toda a bibliografia já publicada sobre o tema. Com a finalidade de um contato 
com tudo o que já foi escrito (MARCONI; LAKATOS, 2010). Ou seja, "os textos tornam-se fontes dos temas a serem pesquisados. 0 pesquisador trabalha a partir das contribuições dos autores dos estudos analíticos constantes dos textos" (SEVERINO, 2007).

A pesquisa bibliográfica permite criar um banco de dados rico em informações sobre o tema escolhido. Tais informações são devidamente selecionadas e direcionam a pesquisa para um resultado rico em dados sistemáticos e relevantes sobre o tema. Enriquecendo ainda mais o meio acadêmico sobre o qual a pesquisa vem tratar.

Posteriormente, foi feita a seleção da bibliografia a ser utilizada, que seguiu o critério de pertinência ao tema. Após isso, foi feita a organização dos assuntos a serem discutidos, e finalmente, a discussão dos resultados da pesquisa.

Este estudo buscou compreender não apenas do que se trata a Psicologia do Esporte, mas principalmente a importância do tema para a sociedade, seus benefícios para os idosos e como aplicar, de maneira prática, tal atividade, sendo também uma importante fonte de pesquisa acadêmica.

Quanto ao material utilizado para a pesquisa, foram selecionados artigos e livros, relacionados ao Envelhecimento, Psicologia do Esporte e Qualidade de Vida do Idoso. Todo o material utilizado foi selecionado de acordo com sua relevância ao tema, e caráter científico, de maneira a dar suporte e segurança para a pesquisa.

No total, foram utilizados 8 livros encontrados na biblioteca da Faculdade Metropolitana de ManausFAMETRO; além de 20 artigos, encontrados na plataforma SCIELO e Google Acadêmico. Todos devidamente embasados do conteúdo pertinente ao tema proposto à pesquisa.

\section{RESULTADOS E DISCUSSÃO}

\section{As condições psicológicas e físicas do idoso brasileiro}

As condições psicológicas e físicas do idoso brasileiro perpassam por questões históricas que culminaram na deficiência de políticas públicas que visem estimular a prática de prevenção da saúde do idoso. Além de que o assistencialismo a pessoa idosa é uma prática recente, o que não acompanhou o aumento significativo desta população no país e no mundo.

Além disso, "no Brasil estima-se que nos próximos 20 anos a população de idosos poderá alcançar e até mesmo ultrapassar a cifra dos 30 milhões de pessoas, o que representará aproximadamente $13 \%$ da população" (MENDES, 2005, p. 423). "Entre os fatores que cooperaram para o crescimento da população idosa no mundo estão: a industrialização, a urbanização, os avanços da tecnologia, da medicina e do saneamento básico e mudança de hábitos pela população, como por exemplo, o ato de lavar as mãos antes das refeições, levando a redução do número de doenças" (SILVA, 2009, p. 21).

No Brasil, a velhice já foi considerada um status social. 0 número de idosos era menor devido às condições que desfavoreciam a longevidade, eram mais valorizados pelos mais jovens, significavam símbolos de respeito, experiência de vida [...] Pode-se considerar que a perda de status dos idosos está relacionada com o surgimento do capitalismo, onde a produção de bens ganha valor. Nesse sistema, valemos mais pelo que produzimos do que pelo que somos, ou seja, a sociedade tende a rejeitar o indivíduo na medida em que ele perde a condição de produzir força de trabalho (BATISTONI, 2009).

Entretanto, a sociedade não está preparada para esse aumento da população idosa, visto que a qualidade de vida não tem acompanhado a evolução populacional. (MENDES, 2005).

Nota-se que o envelhecimento populacional é um fenômeno mundial que provoca grandes desafios à Saúde Pública, tendo em vista a dificuldade de adequação dos serviços a essa nova demanda, tanto quanto à disponibilidade de estrutura física e tecnologias específicas, quanto à escassez de profissionais capacitados a trabalhar com idosos, assim como devido ao universo fisiopatológico e psicossocial singular que esse público representa (BRITO et al, 2013, p. 162).

O aumento exponencial de idosos promove significativo impacto socioeconômico e nos sistemas de saúde, o que torna fundamental que a pessoa idosa permaneça saudável e independente pelo maior tempo 
possível (SOUSA, 2014). Além disso, existe a fase da aposentadoria que apesar de trazer descanso ao idoso, muda toda a sua rotina o que torna uma dificuldade a mais neste período, gerando angústia nesse período (MENDES, 2005). Por isso, "há uma ruptura com o passado, o homem deve ajustar-se a uma nova condição que lhe traz certas vantagens, como o descanso, lazer, mas também graves desvantagens como desvalorização e desqualificação" (MENDES, 2005, p. 424).

Por isso, deve-se encarar a velhice com uma fase normal da vida e não como uma fase improdutiva para que haja mudanças significativas quanto ao papel e importância dos idosos na sociedade brasileira (SILVA, 2009). Pois existe uma premissa histórica de que o idoso era incapaz de se beneficiar de intervenções psicológicas, o que contribuiu para que políticas públicas fossem pouco voltadas para o idoso (BATISTONI, 2009).

Entretanto, tais políticas públicas governamentais têm procurado criar estratégias de atendimento aos idosos tais como, Centros de Convivência - espaço destinado à prática de atividade física, cultural, educativa, social e de lazer, como forma de estimular sua participação no contexto social que se está inserido (MENDES, 2005).

Em contrapartida, é possível afirmar que "as limitações do sistema de saúde pública brasileiro e o rápido processo de envelhecimento apontam para a necessidade de se redefinirem as políticas deste setor, com vistas à necessidade de geração de recursos e de construção de infraestrutura que permitam um envelhecimento ativo" (BRITO et al, 2013, p. 162). Além do mais, acreditava-se também que os problemas psicológicos na velhice eram consequência da inabilidade do idoso em aceitar o seu passado, excluindo ser proveniente do estresse ou inabilidades para enfrentar problemas que se associam às mudanças relacionadas ao envelhecimento (BATISTONI, 2009).

A partir disso, salienta-se que "apesar da criação de novas leis de amparo a velhice, que evidenciam uma preocupação com esta crescente faixa etária, pouco tem sido feito para viabilizar o exercício dos direitos assegurados por estas leis. Ainda é muito parca a atuação governamental efetiva, voltada para este segmento da população" (MENDES, 2005, p. 424). Sobre isso, é possível notar mudanças nos programas e políticas de saúde públicas no Brasil voltadas à população, apesar dessas dificuldades que atualmente o país enfrenta (CAMBOIM et al, 2017). Além disso, a dificuldade de os idosos estabelecerem um estilo de vida fisicamente ativo também constitui um desafio para a implantação de políticas públicas e o avanço em termos de promoção da saúde (SOUSA, 2014).

Pois quando se fala em atividades físicas, a realidade do Brasil e do mundo ainda é bastante precária, apesar de todo o conhecimento que vem sido explorado pelos veículos de comunicação e pelas campanhas governamentais, de que a prática da atividade física é benéfica para a saúde do indivíduo, e pode reduzir os efeitos do envelhecimento.

"Em relação aos programas mundiais de promoção de saúde, os cientistas enfatizam cada vez mais a necessidade da atividade física como parte fundamental, pois neste novo milênio a inatividade física é considerada o principal problema de saúde pública" (BRITO et al, 2013, p. 170). Pois o envelhecimento saudável associado à prática de atividade física requer atenção dos profissionais da saúde no âmbito da atenção primária, formulação de ideias e campanhas que possam chegar ao conhecimento do público idoso e atraí-lo para participar desses programas (CAMBOIM et al, 2017).

Uma das grandes dificuldades para a expansão dos Programas de Atividades Físicas para idosos, sem dúvida, seria a falta de profissionais capacitados para atender ao público em questão, mas que facilmente poderia ser resolvida, pois a Política Nacional do Idoso prevê a possibilidade de articulação de entidades governamentais com organizações não governamentais para viabilizar a capacitação de recursos humanos (BRITO et al, 2013, p. 170).

Além disso, o próprio idoso carrega consigo a falsa ideia de que a velhice o impossibilita de realizar suas atividades físicas, por considerarem-se limitados e inaptos fisicamente. Sobre isso, afirma-se que muitos idosos acreditam não serem capazes de realizar as atividades físicas propostas em Psicologia do Esporte, alegando serem velhos demais (GUIMARÃES et al, 2016). Por isso, a inatividade física nesse grupo ainda é predominante, pois os indivíduos consideram-se frágeis, têm medo de sofrer quedas, não tem orientações e estímulos por parte da família, comunidade ou profissionais da saúde, para o desenvolvimento de atividades ou exercícios físicos regulares (CAMBOIM, 2017).

Entretanto, com os indivíduos vivendo mais, é necessário determinar a amplitude e os mecanismos em que a atividade física pode melhorar a saúde, capacidade funcional, qualidade de vida e independência dessa população (SOUSA, 2014). Pois, segundo "o envelhecimento populacional é um evento que aborda as 
mais diversas discussões sobre saúde pública no que tange às esferas de domínio político, econômico, cultural e social, sendo um direito do idoso envelhecer com qualidade de vida participando ativamente na sociedade com dignidade e respeito" (CAMBOIN, 2017, p. 2417).

Então, pode-se afirmar que o idoso brasileiro encontra primeiramente, inativo quanto à prática de atividades físicas, pois não tem o hábito de se exercitar, culpa a velhice ou outras limitações por não ser ativo. Além disso, o mesmo encontra-se também desamparado pelo sistema público, visto o crescente aumento da população idosa, em concomitância com o despreparo do governo de assistir a essa população, através de políticas públicas voltadas para a estimulação da prática de exercícios físicos.

Tais fatores fazem com que os idosos se encontrem em uma situação de sedentarismo, ou seja, fisicamente inativo e consequentemente, mais adoentado. Daí a importância de se promover novas atividades voltadas para a manutenção da qualidade de vida do idoso.

\section{Atividades desenvolvidas pela psicologia do esporte para a melhoria da qualidade de vida do idoso}

Como dito, a Psicologia do Esporte é uma área considerada nova dentro da Psicologia. E juntamente com a Filosofia, Antropologia e Sociologia do Esporte, integram as ciências do Esporte (RUBIO, 2005).

Implicada em seus primórdios com aspectos mais biológicos, hoje, a Psicologia do Esporte vem estudando e atuando em situações que envolvem motivação, personalidade, agressão e violência, liderança, dinâmica de grupo, bem-estar de atletas caracterizando-se como um espaço onde o enfoque social, educacional e clínico se complementam (RUBIO, 2005, p. 60).

Pois, apesar de trabalhar diretamente com os fatores cognitivos dos indivíduos, a Psicologia do Esporte, que é muito próximo da atividade física e do lazer, sendo inclusive componente curricular dos cursos de Educação Física, mantém-se distante da Psicologia enquanto 'ciência mãe' (RUBIO, 2005).

Além do conhecimento específico em Psicologia, como o uso de instrumentos de diagnóstico e modelos de intervenção, espera-se e exige-se que o profissional tenha um vasto conhecimento das questões que permeiam o universo do esportivo, individualmente, como noções de anátomo-fisiologia e biomecânica, e específicas do esporte, como as modalidades esportivas, bem como dinâmica de grupos esportivos (RUBIO, 2005, p. 62).

Além disso, nota-se que "a prática regular de exercícios físicos pelos idosos melhora a expectativa de vida dos mesmos em relação aos idosos de vida sedentária, em virtude da perda de massa muscular ocorridos com o passar dos anos" (SANTOS; JUNIOR, 2014, p. 42). Além do mais, a prática da atividade física é determinante para as condições de saúde, funcionalidade e qualidade de vida do idoso (SOUSA, 2014).

Por isso, "alguns estudiosos começaram a repensar a Psicologia do esporte deslocando-a de um modelo de habilidades individuais e passaram a observar a necessidade de uma aproximação com a Psicologia social para a compreensão e explicação desse fenômeno complexo e abrangente que é a atividade física e esportiva" (RUBIO, 2007, p. 310).

Portanto, define-se quatro campos de aplicação da Psicologia do Esporte. São eles:

a) esporte de rendimento: o psicólogo atua analisando e transformando os determinantes psíquicos que interferem no rendimento do atleta e/ou grupo esportivo; b) esporte escolar: o psicólogo busca compreender e analisar os processos de ensino, educação e socialização inerentes ao esporte e seu reflexo na formação e desenvolvimento do praticante; c) esporte de reabilitação: o psicólogo trabalha na prevenção e intervenção em pessoas portadoras de algum tipo de lesão decorrente da prática esportiva, ou não, e também com pessoas portadoras de deficiência física e mental; d) esporte recreativo: visa o bemestar para todas as pessoas. É praticado voluntariamente e com conexões com os movimentos de educação permanente e com a saúde. 0 psicólogo, nesse caso, atua na primeira linha de análise do comportamento recreativo de diferentes faixas etárias, classes - sócio econômicas e atuações profissionais em relação a diferentes motivos, interesses e atitudes (SAMULSKI, 1992, apud RUBIO, 2007, p. 64). 
Por isso, abordaremos neste trabalho o esporte recreativo, voltado para a pessoa idosa, como método de promoção de qualidade de vida. Pois, "a elaboração de programas de atividades físicas com os mesmos que objetivem aumentar o desempenho da valência física nesta fase da vida será imprescindível para o aumento da qualidade de vida dos mesmos" (SANTOS; JUNIOR, 2014, p. 42)

Pois, essas atividades físicas não são atividades habituais do dia a dia e têm relação com lazer, bem-estar, então é preciso uma força de vontade por parte do idoso para que seja exercida, uma escolha sua para uma mudança de hábito que promova qualidade de vida no seu envelhecimento (KANASHIRO; YASSUDA, 2010). Por isso, as atividades físicas representam ações mais complexas e estão ligadas à automotivação, visto que não representam ações essenciais para a sobrevivência do indivíduo, pois são atividades ocupacionais, de lazer, voluntariado, atividades físicas, entre outras (KANASHIRO; YASSUDA, 2010).

Portanto, as atividades físicas desenvolvidas com os grupos de idosos sempre se iniciam com alongamentos, buscando grandes e pequenos grupamentos musculares (GUIMARÃES et al, 2016). Além disso, costumeiramente são realizadas também atividades lúdicas promovendo a participação do grupo e interação entre os senescentes (GUIMARÃES et al, 2016, p. 447). Além disso, observa-se que por meio das práticas de atividades físicas e lúdicas as pessoas com limitações vivenciam suas qualidades, emoções, sentimentos, convívio social e independência (GUIMARÃES; ROCHA; MACIEL; ADÃO, 2011).

Entretanto, quanto aos exercícios físicos em si, estes são realizados utilizando movimentos básicos simulando exercícios diários como "varrer", ou segurar em uma barra de apoio no corredor da instituição, levantando e sentando por dez vezes, por exemplo (GUIMARÃES et al, 2016). Além disso, costuma-se também trabalhar com dinâmicas de grupos referentes à memória, noção temporal e relações interpessoais, incentivando a comunicação entre idosos e psicólogo (GUIMARÃES et al, 2016).

Por isso, pode-se perceber que muitos são os meios de se trabalhar com idosos, através de inúmeras atividades, tanto esportivas como lúdicas, que possam promover uma mudança de hábitos em suas vidas. São atividades que promovem melhorias significativas para sua saúde como um todo, tanto física, quanto psicológica. Além disso, são responsáveis pela maior interação social entre os idosos que naturalmente já sofrem durante essa fase difícil que é o envelhecimento.

Portanto, essas atividades precisam ter um acompanhamento de profissionais dispostos a trabalhar juntamente com idosos, a partir de suas limitações, os encorajando a manter hábitos saudáveis. Permitindo que os mesmos encarem o envelhecimento de maneira menos sofrível possível.

\section{Os benefícios da psicologia do esporte para qualidade de vida do idoso}

A prática da atividade física é com certeza, um dos principais fatores para o envelhecimento saudável. Um estudo longitudinal, envolvendo 1321 idosos independentes, mostrou que além da idade, a ausência da prática de atividade física regular também é preditiva de limitações nas atividades de vida diária (KANASHIRO; YASSUDA, 2010). "A prática de atividade física é um benefício indispensável à saúde corporal e mental, principalmente na terceira idade, quando a capacidade funcional sofre declínio e o organismo enfraquece tornando-se suscetível ao desenvolvimento de doenças" (COMBAIM et al, 2017, p. 2416).

Além disso, o envelhecimento é um processo dinâmico e progressivo, no qual se percebem alterações morfológicas, funcionais, bioquímicas e psicológicas, que determinam a perda na capacidade de adaptação do indivíduo ao ambiente, o que o torna mais vulnerável a doenças (SOUSA, 2014). 0 que torna fundamental a prática de atividade física para o envelhecimento com menores riscos de doenças.

Observa-se que a maior prática de atividades no dia a dia está associada a menor declínio cognitivo e funcional, sentimentos de bem-estar e redução no risco de mortalidade (MENEC, 2003). Além disso, afirma-se que as atividades físicas são intervenções primordiais no processo de envelhecimento, e contribui para uma maior qualidade de vida (GUIMARÃES et al, 2016).

Essas atividades quando estruturadas e planejadas, oferecem benefícios que são relevantes para evitar, minimizar e até mesmo reverter o declínio físico, psicológico e social comuns ao processo de envelhecimento (SOUSA, 2014).

A evolução tecnológica aumentou muito os problemas de saúde decorrentes de maus hábitos alimentares e a diminuição de esforço físico no cotidiano das pessoas. Este fenômeno desencadeou investigações que comprovaram a eficiência da atividade física, para fornecer um reequilibro físico e mental para a 
vida da humanidade. Com isto abre-se uma nova área de atuação dos estudiosos da Psicologia do Esporte (EPIPHANIO, 2005, p. 72).

Além disso, os exercícios físicos podem propiciar benefícios à diminuição das doenças crônicas degenerativas que, atualmente, acometem os idosos, por exemplo, doenças cardíacas, acidente vascular cerebral, doenças respiratórias crônicas, diabetes, deterioração visual e auditiva (GUIMARÃES et al, 2016). Entretanto, a dificuldade em participar das atividades avançadas pode não indicar perda funcional atual, porém risco de perdas funcionais futuras mais importantes (PAIXÃO; REICHENHEIM, 2005).

Os exercícios físicos foram iniciados para promover uma aproximação dos idosos na tentativa de identificar suas carências e realizar a proposta de contribuir na autonomia funcional para realização das atividades da vida diária e melhoria na qualidade de vida, minimizando os efeitos das doenças crônicas degenerativas, bem como prevenindo os demais agravos da saúde física e psicológica que ocorrem com a senilidade" (GUIMARÃES et al, 2016, p. 450)

"O sentido pessoal no esporte auxiliou os atletas a superarem crises e perdas ao longo da vida, e com isso obtiveram progressos no desenvolvimento numa fase que se iniciam ou que se percebem maiores declínios e perdas" (ALMEIDA, 2011, p. 238). Nesse sentido, descreve-se a atividade física como "coadjuvante na melhoria da qualidade de vida, embora ressaltem a importância de se considerar as limitações do indivíduo e a valorização do seu potencial nas atividades propostas" (GUIMARÃES; PASCOAL; CARVALHO; SACRAMENTO, 2012).

Além disso, "os programas direcionados ao envelhecimento precisam conter caráter sócioeducacional, no qual a velhice não seja encarada sob o viés de declínio das funções orgânicas e da vitimização do sujeito idoso, mas sim na busca de contribuir para sua atualização cultural e participação da vida em sociedade, de forma autônoma e constituindo-se um ser agente no contexto em que vive" (VENDRUSCOLO et al, 2011).

Os indivíduos possuem capacidade de aprender e, a partir desses aprendizados, constroem um conhecimento que permite se adaptarem a qualquer dificuldade que possa apresentar, pois possuem no grupo de amigos um apoio importante, assim como no treinador ou no próprio médico, que permite crescimento e desenvolvimento no esporte (ALMEIDA, 2011, p. 238).

Além disso, após as atividades físicas grupais, os idosos aprenderam melhores maneiras de lidar com o outro e aperfeiçoar suas relações sociais, desenvolvendo valores pessoais, e aprenderam a conviver com situações adversas e aprimoraram sua forma de enfrentar desafios (ALMEIDA, 2011). Pois, o esporte produz nos indivíduos efeitos positivos no processo de desenvolvimento social, tanto em idosos sadios quanto em indivíduos com algum tipo de patologia. Além disso, o esporte parece ainda proporcionar maior contato com outras pessoas, permitindo maior inserção social (ALMEIDA, 2011).

Diante disso, " brincar em grupo estimula as relações e a competição, e é por meio desse relacionamento que as pessoas estabelecem vínculos entre si" (GUIMARÃES et al, 2016, p. 450). Portanto, "o esporte pode e deve ser utilizado como uma ação social, pois é benéfico à saúde, é prazeroso, e ainda pode ser uma perspectiva de futuro profissional. Não há dúvidas quanto a melhoria de vida que a prática esportiva, bem acompanhada, pode trazer a qualquer ser humano" (EPIPHANIO, 2005, p. 71).

"Os atletas possuem as características de independência na condução de suas próprias necessidades, de autonomia com relação a sua prática esportiva e de controle das suas perdas a partir do aprendizado que desenvolveram com elas" (ALMEIDA, 2011, p. 238). Além disso, a atividade física potencializa as ações musculares dos indivíduos, estimulando seus membros a fim de resgatar a autoestima, autonomia, reconhecendo e diminuindo as limitações próprias da idade, destacando a importância de manter-se ativo fisicamente (GUIMARÃES et al, 2016).

Portanto, "os exercícios físicos e as atividades lúdicas apresentaram resultados como a estimulação da memória remota e recente" (GUIMARÃES et al, 2016, p. 449). Além disso, "a atividade física e o esporte promovem em seus praticantes uma aprendizagem contínua, quando o indivíduo vê algum significado na atividade" (ALMEIDA, 2011, p. 236).

Entretanto, quanto aos benefícios psicológicos, programas de exercícios físicos para idosos, além de contribuir para a melhoria de aspectos biológicos e físicos, favorecem a satisfação com a vida, reduzem a solidão, estimulam a autoconsciência corporal, o que propicia a retomada da interação com o mundo (CASTRO et al, 2016). 
Além disso, a atividade física pode trabalhar as emoções, desenvolver a afetividade, estimular a convivência, diminuir o nível de ansiedade e de angústia, além de exercitar as funções psíquicas e cognitivas (GUIMARÃES et al, 2016). Pois "os atletas, por estarem em permanente contato com o novo, desempenhando atividades, aprendendo coisas diferentes, mantêm papéis sociais que lhes sejam significativos, de modo a manterem o sentido de vida" (ALMEIDA, 2011, p. 238).

Por isso, "o estilo de vida mais ativo proporcionado por intervenções de exercícios físicos em idosos também colabora para equilíbrio psicoafetivo e reduz índices de depressão e ansiedade favorece a melhoria na autoestima e motivação, como destacado pelos participantes" (CASTRO et al, 2016, p. 287). Além disso, "podem reduzir os fatores estressores, minimizando a ansiedade e a angústia presentes no cotidiano, uma vez que, nesse espaço, a expressão de sentimentos e a comunicação são favorecidas por meio da formação de grupos" (GUIMARÃES et al,2016, p. 446).

Portanto, pode-se considerar que a Psicologia do Esporte é uma área da Psicologia importantíssima para a promoção de saúde entre os indivíduos, e principalmente quando se trata da população idosa. Pois são inúmeros os benefícios para a promoção da qualidade de vida, os quais foram citados neste trabalho.

Pois, os idosos praticantes de atividades físicas adoecem menos e/ou mais tardiamente de doenças crônicas, cardiovasculares e fisiológicas, tornando-os mais ativos fisicamente, beneficiando a si próprio e a sociedade como um todo, pois idosos mais saudáveis se hospitalizam com menos frequência, por exemplo.

Além disso, quando o idoso é praticante de atividades físicas, o mesmo torna-se por ser mais saudável psicologicamente, pois a atividade física o deixa mais disposto e mais feliz. Além de permitir maior interação com os grupos de outros idosos, fazendo com que o mesmo socialize mais e estimule habilidades importantes como linguagem, raciocínio, memória, dentre outros. Tais fatores fazem com que idosos se tornem menos vulneráveis a doenças como depressão, ansiedade, etc. Que são doenças que costumam afetar a população idosa, devido às limitações já citadas, que vêm juntamente com o envelhecimento. Por isso, é correto afirmar que a Psicologia do Esporte, juntamente com as atividades pertinentes à área de atuação para a população idosa, é um fator crucial para a promoção da qualidade de vida entre os idosos.

\section{CONSIDERAÇÕES FINAIS}

A Psicologia do Esporte é uma área relativamente nova dentro da Psicologia, por isso ainda são poucas as pesquisas e discussões sobre a área dentro da ciência. Muito caminho ainda se tem a percorrer para que a Psicologia do Esporte tenha o espaço devido dentro da pesquisa científica.

Além disso, sabe-se que as faculdades ainda não têm em sua grade obrigatória a disciplina. Ou seja, um psicólogo formado não tem conhecimento sobre a área, a não ser que, por recursos próprios, tenha procurado estudar a respeito.

Percebeu-se durante a discussão do trabalho que um psicólogo do Esporte, além de entender o funcionamento psíquico de um idoso, deve ter conhecimentos aprofundados sobre o funcionamento fisiológico do indivíduo, devido as atividades que o mesmo desenvolve, durante a prática da atividade física.

Quanto à execução da pesquisa, percebeu-se também que houve certa dificuldade para encontrar bibliografia relacionado ao tema. Tal dificuldade deve-se ao fato já relatado, de que esporte se trata de uma área nova para a Psicologia, o que faz com que trabalhos acadêmicos voltados para a Psicologia do Esporte, tenham sido feitos em um período de tempo recente também. Tal carência em bibliografia foi notada principalmente quanto às atividades físicas em si, pois foi observado que eram poucos os trabalhos ou livros que descrevessem ou elucidassem detalhadamente sobre as atividades que são realizadas dentro de um atendimento voltado para o idoso ou grupo de idosos. Este problema não impediu que a pesquisa fosse realizada com êxito, apesar de sua notória presença.

Portanto, vale ressaltar a importância de novas pesquisas voltadas para a área da Psicologia do Esporte, para que a mesma possa ter cada vez mais espaço dentro das ciências psicológicas. E este trabalho se propôs a contribuir, sendo mais uma dessas pesquisas voltadas para a área, trazendo novas informações sobre o tema de forma sistemática e precisa.

Entende-se que é necessário que as faculdades de psicologia e educação física incluam em suas grades a Psicologia do Esporte, visto que os benefícios discutidos que são claros para a qualidade de vida de qualquer indivíduo, e principalmente do idoso. Pois, como já dito, a população idosa tem crescido e precisa 
do suporte dos profissionais de Psicologia para que possam direcionar melhor o atendimento, objetivando a qualidade de vida da pessoa idosa.

Por fim, considera-se satisfatória a realização da pesquisa, visto ser rica em informações sobre o tema proposto, sendo clara sua contribuição para o público em geral, sociedade e comunidade acadêmica. Pois todos podem contar com importante fonte de informações sobre a relação direta que existe entre a qualidade de vida do idoso e a prática da atividade física.

Portanto, pode-se então afirmar que os objetivos foram alcançados, visto que a literatura oferece provas concretas sobre a importância da Psicologia do Esporte para a qualidade de vida do idoso. De maneira que os benefícios são múltiplos, e são percebidos tanto no caráter físico, quanto no caráter psicológico da pessoa idosa.

\section{REFERÊNCIAS}

[1] ALMEIDA, S. T. Envelhecimento bem-sucedido e as aprendizagens no esporte competitivo: uma forma de adaptação de atletas que praticam corrida. Revista Brasileira de Geriatria Gerontologia, Rio de Janeiro, v. 14, n. 22, p. 233-239, 2011.

[2] BATISTONI, S. T. Contribuições da Psicologia do Envelhecimento para as práticas clínicas com idosos. Psicologia em Pesquisa, São Paulo, v 3, p. 13-22, 2009.

[3] BEE, H. O ciclo vital. 7. ed. Porto Alegre: Artmed, 2001.

[4] BRITO, M. C. et al. Envelhecimento Populacional e os Desafios para a Saúde Pública: Análise da Produção Científica. Revista Kairós Gerontologia. São Paulo, v. 16, p.161-178. 2013

[5] CAMBOIM, F. E. et al. Benefícios da atividade física na terceira idade para a qualidade de vida. Revista de Enfermagem UFPE online, Recife, v. 11, n. 6, p. 2415-2422, 2017.

[6] CASTRO, M. R. et al. Jogos recreativos para a terceira idade: uma análise a partir da percepção dos idosos. Revista Brasileira Ciências do Esporte, Maranhão, v. 38, n. 3, p. 283-289, 2016.

[7] DÁTILA, G. M.; CORDEIRO, A. P. Envelhecimento Humano: diferentes olhares. São Paulo: Cultura Acadêmica, 2015.

[8] EIZERIK, C. L. et al. 0 ciclo de vida humana: uma perspectiva psicodinâmica. Porto Alegre: Artmed Editora, 2007.

[9] GUIMARÃES. A. C. et al. Atividades grupais com idosos institucionalizados: exercícios físicos funcionais e lúdicos em ação transdisciplinar. Revista Pesquisas e Práticas Psicossociais, São João del-Rei, v. 11, n. 2, p. 443-452, 2016.

[10] GUIMARÃES, A. C., ROCHA, G. B. D., MACIEL, M. G., ADÃO, K. D. S. Pensando as práticas de intervenção dos discentes do curso de licenciatura em Educação Física na Associação de Pais e Amigos dos Excepcionais (Apae) do Município de São João del-Rei/MG. Revista Pesquisas e Práticas Psicossociais, São João del-Rei, v. 6, p.149-154, 2011.

[11] KANASHIRO, M. YASSUDA, M. Estudo da Adaptação e Aplicabilidade do Questionário Perfil de Atividades de Adelaide em Idosos de uma Comunidade Nipo-brasileira. Psicologia: Reflexão e Crítica, São Paulo, v. 24, n. 2, p. 245-253, 2010.

[12] LAKATOS, E. M., MARCONI, M. A. Técnicas de pesquisa: planejamento e execução de pesquisas, amostragens e técnicas de pesquisa, elaboração, análise e interpretação de dados. 7. Ed. São Paulo: Atlas, 2010.

[13] MACIEL, M. G. Atividade Física e funcionalidade do idoso. Revista de Educação Física. São Paulo, v.16, n.4, p.1024-1032, out./dez, 2010.

[14] MENDES, M. R. et al. A situação social do idoso no Brasil: uma breve consideração. Revista Acta Paul Enfermagem, São Paulo, v. 18, n. 4, p. 422-426, 2005.

[15] MENEC, V. The relation between everyday activities and successful aging: A 6-year longitutinal study. Journal of Gerontology: Social Sciences, Manitoba, v. 58, n. 2, p. 74-82, 2003.

[16] NERI, A. L. Qualidade de vida e idade madura. 8. ed. São Paulo: Papirus, 2009. 
[17] PAIXÃO, C. M. REICHENHEIM, M. E. Uma revisão sobre instrumentos de avaliação do estado funcional do idoso. Cadernos de Saúde Pública, v. 21, n. 1, p. 7-19, 2005.

[18] PAPALIA, D. E., FELDMAN, R. D. Desenvolvimento Humano. Porto Alegre: AMGH, 2013.

[19] PINHO, H. C. A Psicologia E O Psicólogo Do Esporte: Uma Formação Necessária. Instituto de Psicologia, $\quad$ Brasília, $2016 . \quad$ Disponível em: https://repositorio.unb.br/bitstream/10482/20801/1/2016_HugoSoaresPinho.pdf> Acesso em 4 set. 2020 as $19: 42$.

[20] RUBIO, K. Ética e Compromisso Social na Psicologia do Esporte. Psicologia, Ciência e Profissão, São Paulo, v. 27, n. 2, p. 304-315, 2007.

[21] RUBIO, K. A Psicologia do Esporte: Histórico e Áreas de Atuação e Pesquisa. Psicologia, Ciência e Profissão, São Paulo, v. 19, n. 3, p. 60-69, 2007.

[22] SANTOS, F. S. JUNIOR, J. L. O Idoso e o Processo de Envelhecimento: Um estudo sobre a qualidade de vida na terceira Idade. Id Online Revista de Psicologia, Crato, v. 8, n. 24, p. 34-55, 2014.

[23] SEVERINO, A. J. Metodologia do Trabalho Científico. 23. ed. São Paulo: Cortez, 2007.

[24] SILVA, V. Velhice e envelhecimento: qualidade de vida para os idosos inseridos nos projetos do sesc-estreito. 2009. Trabalho de Conclusão de Curso (Bacharelado em Serviço Social) - Universidade Federal de Santa Catarina, Florianópolis, 2009. Disponível em: < http://tcc.bu.ufsc.br/Ssocial287076.pdf> Acesso em: 7 set. 2020.

[25] SOUSA, F. C. Prática de Atividade Física em Idosos: autoeficácia, benefícios e barreiras percebidas. 2014. Dissertação (Mestrado em Educação Física) - Universidade de Brasília, Brasília, 2014. Disponível em: < https://repositorio.unb.br/bitstream/10482/16719/1/2014_FabianyCalixtodeSousa.pdf> Acesso em: 7 set. 2020 .

[26] VENDRUSCOLO R, et al. Programas de atividade física para idosos: apontamentos teóricometodológicos. Pensar a Prática, Goiânia, v. 14, n. 1, p. 1-13, jan./abr. 2011

[27] VIEIRA, L. F. et al. Psicologia Do Esporte: Uma Área Emergente Da Psicologia. Psicologia em Estudo, Maringá, v. 15, n. 2, p. 391-399, abr./jun., 2010.

[28] ZIMERMAN, G. I. Velhice: Aspectos Biopsicossociais. Porto Alegre: Artmed, 2000. 


\section{Capítulo 7}

\section{O homem e a ocupação: Uma discussão acerca da relação do homem com o trabalho}

\section{Lucas de Sá Moraes}

Resumo: 0 modo como o homem se relaciona com o trabalho diz muito sobre si, sobre suas vivências e o contexto em que vive. Diversos povos se relacionam de maneiras diferentes com o trabalho, sendo castigo para alguns e dádiva para outros. Porém, este fenômeno não é algo remoto no tempo, até hoje encontram-se maneiras de compreender o trabalho e se relacionar com tais atividades. Partindo desse princípio, o presente estudo tem como objetivo geral discutir a maneira que o homem se relaciona com seu trabalho, o que é denominado psicodinâmica do trabalho, a partir da compreensão que o próprio homem tem sobre o labor e o valor do trabalho no contexto ao qual está inserido. 0 que se pôde constatar a partir da pesquisa, é que o trabalho não é somente um meio para sobreviver, pois possui um significado maior na vida do homem. Sendo causa de sofrimento ou um meio de se obter sentido na vida, o trabalho tem um papel de extrema importância na vida dos que o executam, pois proporciona um valor social ao homem, ao passo que este valor contribui para a crença de dignidade e utilidade perante si e a sociedade em geral. 0 tipo de pesquisa utilizado neste trabalho foi uma pesquisa bibliográfica, qualitativa e sistemática, que permitiu um acesso maior aos materiais desenvolvidos na área.

Palavras-Chave: Homem; trabalho; valor social; psicodinâmica do trabalho. 


\section{INTRODUÇÃO}

0 tema central desta pesquisa é a relação que o homem estabelece com o trabalho, partindo desde a concepção de trabalho à compreensão da civilização ocidental sobre a atividade laboral, bem como as influências na vida do indivíduo nos aspectos físico, mental e social, tendo como objetivo geral discutir como o homem se relaciona com o trabalho. Quanto aos objetivos específicos foram estabelecidos: a. Descrever o modo em que o ser humano lida com o trabalho; b. Identificar os fatores que influenciam na saúde mental do indivíduo; e c. Identificar o valor social do trabalho na vida do indivíduo.

Ao pensar como o homem se relaciona com o trabalho, é possível que o pensamento seja movido aos tempos das cavernas, do imaginário popular, em que tais espécies trabalhavam para sua própria sobrevivência. Porém, bastante tempo depois, isto ainda pode ser visto.

Com o passar do tempo, o trabalho foi ganhando características novas, o que por sua vez, dava uma compreensão diferente das pessoas acerca do tema. No contexto grego antigo, o trabalho era primeiramente visto como uma forma de manter a espécie (BENDASSOLI, 2011), porém, era também uma forma de aproximar o humano ao divino, como afirma Vernant (1990) apud Bittencourt (2010). Dessa forma torna-se fácil compreender as diversas roupagens que o trabalho assumia em um mesmo contexto.

Embora citado somente o contexto da Grécia antiga, esta discussão abordará como eram vistas as atividades laborais no contexto medieval a partir de uma visão religiosa, e como esta visão perdurou por tanto tempo na civilização do Ocidente, mesmo após a Idade Média.

Além de considerar como o homem compreendia o trabalho, é preciso levar em conta como ele se relaciona a partir de tal compreensão, tendo em vista que esse é o foco deste estudo, portanto, as visões de teóricos da psicologia e sociologia estarão presentes apresentando os efeitos dessa relação, seja positiva ou negativa. A partir das discussões sobre o sentido de vida advindo do trabalho, o valor social do trabalho e o sofrimento a partir do trabalho, será melhor de identificar os fatores fundamentais da psicodinâmica do trabalho tendo como base grandes teóricos que abordaram sobre o tema, como Viktor Frankl que identifica o trabalho como meio de transceder e com isso encontrar sentido na vida; Hannah Arendt que utiliza de dois termos para descrever o homem em sua atividade, são eles animal laborans e homo faber, e coloca o trabalho como condição humana.

A relevância desta pesquisa para a ciência se dá pela contribuição para a atuação do psicólogo nas áreas organizacionais, de trabalho e gestão de pessoas. 0 entendimento da relação do homem com o trabalho facilita a atuação do psicólogo em diferentes campos de atuação, além dos já citados, pode ser pensado até mesmo no contexto clínico, dependendo da demanda existente. No entanto, como será abordado de forma mais profunda posteriormente, a relação homem x trabalho não acontece somente no âmbito laboral, mas é levada para fora desse ambiente também. Dessa forma, a partir do momento que se tem conhecimento dos fenômenos advindos deste tipo de situação, é permitido ao profissional uma atuação concreta e clara.

Além da contribuição específica para a ciência da psicologia, a pesquisa realizada possui aspectos positivos para a sociedade. 0 conhecimento adquirido permite uma visão diferenciada a respeito do tema, possibilitando que a sociedade de modo geral tenha em mente que a psicodinâmica do trabalho possui tanto influências positivas, quanto negativas na vida do indivíduo, contribuindo dessa forma, para a manutenção da saúde mental e conhecendo fatores de risco à mesma.

Por fim, a sua contribuição para a academia tem parte devido ao projeto que levará o nome da instituição consigo, e possibilitará o acesso de estudantes e professores à seu acervo de trabalhos de conclusão de curso, permitindo o uso em demais projetos.

Este trabalho foi elaborado a partir de diversas leituras, trabalhos anteriores em âmbito acadêmico e vivências pessoais que permitiram considerar estudar tal tema e compreender melhor este fenômeno, além de contribuir para o crescimento do acervo de pesquisas sobre a psicodinâmica do trabalho.

\section{REFERENCIAL TEÓRICO}

\section{0 trabalho}

Primeiramente é importante esclarecer alguns termos que serão utilizados no presente trabalho, pois podem ser causas de diferentes interpretações acerca do tema. Lhuilier (2006) Apud Enriquez (2014) aponta para a seguinte questão, nunca se deve confundir os seguintes termos, trabalho assalariado, atividades e emprego, portanto, quando o tal projeto se refere a trabalho, este não será compreendido de forma reduzida. Com trabalho, estão relacionadas as atividades desenvolvidas a partir da motivação do 
indivíduo, ou seja, atividades que despertem o interesse do sujeito para sua realização, desde um emprego, algo formal, até mesmo o simples ato da prática de atividades funcionais em um centro de convivência para idosos.

As atividades citadas por Eriquez (2014) se diferenciam de lazer pelo fato de possuirem papel idêntico ao do trabalho assalariado, dando identidade e função social ao indivíduo. 0 presente estudo no entanto, não se limitará a somente uma visão acerca do trabalho, todavia, abordará a relação do homem com a ocupação, sendo desse modo, incluídas as atividades funcionais, os serviços do emprego, a labuta e o trabalho criativo.

A palavra "trabalho" na língua latina é oriunda de tripalium, um objeto de tortura (GLINA; ROCHA, 2012). Do grego origina-se work, usado no inglês, advindo de érgon, e tem-se o no idioma alemão werkam, que pode ser entendido como jogos ou diversão (GLINA; ROCHA, 2012). Desse modo fica mais fácil compreender como simples atividades possuem papel identico ao trabalho, visto que na língua alemã, a palavra trabalho pode ser entendida também na forma de diversão, pois trata-se de uma ocupação.

\section{0 homem x trabalho}

Sobre a relação do homem com o trabalho, Weil (2005) destaca alguns pontos do fator humano no ambiente laboral, são eles: a adaptação do homem ao trabalho; a adaptação do trabalho ao homem; e adaptação do homem ao homem. Zanelli (2010) afirma que o homem é transformado e transforma também o ambiente de trabalho, este pensamento pode ser vinculado ao primeiro e segundo ponto da relação do homem com o trabalho, de adaptação ao trabalho e adaptação do trabalho. 0 terceiro ponto diz respeito ao ambiente de trabalho baseado no respeito mútuo entre os demais trabalhadores (WEIL, 2005).

0 que Weil (2005) afirma quando destaca os fatores humanos nas organizações é confirmado por Schimidt (2010) ao utilizar da teoria sociodramática de Moreno para apontar características das relações humanas no trabalho a partir do conceito de criatividade-esponeidade. Este conceito se aplicado à psicodinâmica do trabalho, permite pensar que no que se refere à postura do trabalhador no ambiente laboral, isto não é estático, pois está em constante adaptação ao meio (WEIL, 2005).

Além do simples fato do homem adaptar-se ao trabalho e adaptar o trabalho a si, é visível que mesmo com as constantes transformações no trabalho, ambientes estressantes que desgastam e colocam em risco a saúde mental e física do trabalhador, ele exerça seu trabalho com qualidade por inúmeros fatores. De forma clara e objetiva, o homem exerce seu trabalho, podendo a este ser atribuído significado positivo ou negativo. Prazer e sofrimento são resultados do trabalho.

Para essas e outras questões, se pretende abordar as patologias do trabalho, como estresse e burnout, bem como utilizar da visão de Viktor Frankl para entender o modo que o homem encontra sentido em seu trabalho, mesmo que por vezes seja extremamente doloroso. Esta ótica será utilizada também como um comparativo com os conceitos de animal laborans e homo faber de Hannah Arendt.

Comparar os conceitos de homem como um ser transcendente por meio do trabalho relatado por Kroeff (2011) ao assim citar Frankl, contraria o pensamento de Arendt (2005) que acredita ser condição humana o trabalho, porém, a relação que o homem estabelece com o trabalho não permite dizer que isto transcende sua existência. Arendt estabeleceu dois termos a serem uilizados paa descrever o homem no trabalho, são eles: animal laborans e o homo faber, e estas duas "espécies", se assim se pode dizer, utilizam do trabalho como sobrevivência e outra como meio para algo, não tendo o fim em si.

Miguez (2015) aponta para algo importante no que diz respeito ao pensamento de Hannah Arendt, o trabalho corresponde à criação da vida artificial e artefatos, e por este motivo não possui finalidade em si mesma. 0 ponto que Arendt (2005) considera importante na relação homem e trabalho, é o qual não se pode dissociar a existência humana do trabalho, pois de acordo com sua própria obra, o trabalho é a condição humana.

Indo mais a fundo nesse ponto da condição humana do trabalho, Peterson (2018) aborda sobre a mesma questão, o trabalho de fato é a condição da exitência humana, no entanto, não próprio dos humanos. 0 ponto que Peterson (2018) quer chegar aproxima-se com o pensamento de Frankl (2018), ao destacar a importância de se ter uma tarefa a cumprir e conferir sentido à execução do trabalho. Neste ponto, a noção que Peterson e Frankl têm sobre trabalho se aproximam ao considerarem o trabalho como condição humana a partir de seus aspectos. 
Frankl (2018) por sua vez, contraria o entendimento de Arendt (2005) a respeito do animal laborans e do homo faber. Não é considerável para a teoria do psiquiatra austríaco que o homem seja incapaz de transcender na realização de um ato, o trabalho. 0 trabalho é para Frankl um meio de encotrar sentido na vida (FRANKL, 1987), que por sua vez é transcender, característica principal do existir (FRANKL, 2018).

0 trabalho, portanto, estaria intrínsicamente ligado à existência humana, como bem afirma Demo (2006) ao comentar que "será trabalho também o não-trabalho, porque se viver é trabalhar, deixar de trabalhar ainda é viver e, portanto, trabalhar. Por uma confusão apressada, tendemos a não ver trabalho no lazer, na diversão, no esporte." (p. 9)

A partir disso Demo (2006) exemplifica o trabalho em um modo diferente, além do qual se está acostumado a entender. É trazido por ele uma característica do trabalho bastante interessante, a vida como trabalho. Peterson (2018) aborda o trabalho como sacrifício, sendo o adiamento da gratificação, contudo, na sentença de Demo (2006) é possível traçar um paralelo entre ambos pelo fato de entenderem o peso do trabalho na vida. Isso é bem visto quando é dito que viver é trabalhar.

Por esse motivo, tanto Demo (2006), quanto Peterson (2018) compreendem o fardo do trabalho, o que para alguns seria entendido como labuta, referente ao trabalho pesado, sofrido.

\section{Sofrimento no trabalho}

Quando se pensa em sofrimento a partir do trabalho logo se volta para os tempos de revolução industrial, em que jovens, crianças, homens e mulheres trabalhavam pesado e sem direito algum. Contudo, não descartando o sofrimento das pessoas dessa época, hoje também se tem uma forma de sofrer característica do período em que vivemos, por assim dizer. É preciso compreender o homem a partir de sua era e não desprezar suas vivências.

Heloani e Capitão (2003) alertam que o trabalho não necessariamente é causa de doenças, porém, pode servir como um estímulo para o desenvolvimento delas. Desse modo, quando se pensa em sofrimento e patologia advinda do trabalho, nos leva a pensar em burnout, que se trata do estresse laboral.

O estresse é a reação do sujeito frente a um estímulo que lhe causa tensão emocional (HONORATO; MACHADO, 2019), não sendo necessariamente somente no ambiente de trabalho, já o burnout, significa combustão e este sim se limita ao estresse em decorrência do trabalho (VIEIRA; RUSSO, 2019).

O burnout trata-se de um acúmulo de eventos estressores, que consiste no indivíduo chegar ao limite de suas faculdades mentais e físicas. Esse acúmulo não permite que o trabalhador desenvolva seu papel, como bem afirma Zanelli (2010), o sujeito não vislumbra uma finalidade na execução de suas tarefas, comprometendo seriamente sua saúde mental.

\section{A psicologia na relação homem x trabalho}

Muito mais do que as teorias por trás da psicodinâmica do ambiente laboral, este trabalho tem por objetivo descrever o modo de relacionamento, as interferências do ambiente laboral no ambiente familiar e suas influências na saúde mental do indivíduo. Por este motivo se abordará sobre a visão da psicologia nestes aspectos a partir de autores que já abordam sobre o tema. Para descrever esta visão, é preciso fazer uma divisão nas áreas relacionadas à psicologia industrial e organizacioal, o que é visto em Zanelli (2002) ao separar esta área em subcategorias como: Psicologia Pessoal; comportamento organizacional; ergonomia; aconselhamento de carreira e vocacional; desenvolvimento organizacional e relações industriais (ZANELLI, 2002). A pretensão de Zanelli (2002) ao dividir o estudo da psicologia organizacional nestes tópicos, é necessariamente ressaltar os diversos aspectos da psicodinâmica do trabalho, do mesmo modo que Weil (2005) destacou.

Desse modo, não se entende a relação do homem com o trabalho a partir de uma ótica mecanicista, pelo contrário, considera-se a dinâmica estabelecida no ambiente laboral e se leva em conta a influência na vida do indivíduo. Dall'Bello (2019) afirma que as atividades que o sujeito exerce no trabalho são dotadas de sentido, e isto se observa como consequência da relação de troca que o homem etabelece em sua ocupação, ao ponto que Zanelli (2014) concorda com tal afirmação ao dizer que o caráter dinâmico do trabalho possui característica emancipadora.

O papel da psicologia no estudo da relação que o homem estabelece com o trabalho, não diz respeito somente ao campo patológico, ou seja, das doenças advindas do ambiente de trabalho. Contudo, um bom 
campo a ser estudado é o valor social que o homem adquire a partir do trabalho, havendo a possibilidade de ser estudado até por outras ciências, como a sociologia.

Na Grécia antiga, já poderia ser compreendido como era visto o trabalho e seu valor social, em um artigo sobre o valor do trabalho para Hesíodo, poeta grego, Bittencourt (2010 p. 87) afirma que "Valoroso e virtuoso não é apenas o herói que se dispõe a pegar em armas, mas também quem na vida árdua e disciplinada do campo produz com o fruto de seu trabalho aquilo que é essencial para a pólis."

A partir disso, já se torna possível vislumbrar o que os gregos de outrora consideravam do homem que trabalha, era algo valoroso, ou seja, possuía valor a obra executada, pois de acordo com Vernant (1990) apud Bittencourt (2010) pelo trabalho são instituídas novas relações entre os homens e os deuses, o que caberia considerar que o trabalho purificava o homem, o dando mérito para receber graças divinas (BITTENCOURT, 2010).

Este seria um dos objetos de estudo de uma psicologia que se importa com a integralidade do ser humano e sua relação com o trabalho, afinal, o relação estabelecida pelo homem com sua atividade, não é apresentada somente em ambiente laboral.

\section{Valor social do trabalho}

Um dos pontos a se destacar no pensamento de Hesíodo é o de trabalho valoroso, dito por Bittencourt (2010), partindo deste pensamento, caberia destacar que valor o trabalho dá à vida do homem. Schimidt (2010) utiliza do conceito de espontaneitade e criativiadade da teoria sociodramática de Moreno para exemplificar este fator, pois o papel que o homem exerce no trabalho está ligado ao valor que ele dá ao homem.

A realização de uma atividade se exercida de forma mecânica, sem espontaneidade acaba por criar emoções superficiais (SCHIMIDT, 2010), e neste caso o valor que esse trabalho traria a essa pessoa seria algo negativo. Se levar em conta o valor a partir de tribos indígenas, será visto que o papel que eles desempenham em sua aldeia diz muito sobre a identificação deles com os demais. Homens e mulheres são ensinados desde cedo a executar determinadas tarefas que o valorizam socialmente (TORRES, 2007).

\section{PROCEDIMENTOS METODOLÓGICOS}

Para este trabalho foi utilizado o método qualitativo de pesquisa, que segundo Neves (1996), este tipo de pesquisa costuma ser direcionada em seu desenvolvimento, além de não numerar ou medir eventos. Afirmação importante se levado em conta o objeto de estudo da pesquisa, pois um evento dessa amplitude pode ser melhor compreendido se analisado a partir das partes nele envolvidas, considerando todos os pontos de vista (GODOY, 1995), neste caso em específico, as partes foram as visões de cada autor que contribuíram para o enriquecimento da discussão em sua totalidade.

0 trabalho foi produzido a partir de uma pesquisa bibliográfica, que trata-se de um levantamento do acervo de pesquisas já analisados, permitindo ao pesquisador conhecer o que já foi estudado anteriormente (ARAUJO et al, 2020). Com isso foram utilizadas plataformas digitais que permitem acesso aos materiais já desenvolvidos, como Scielo, Bvs, BvsPsi e revistas de estudos acadêmicos, além dos próprios sites das universidades para o acesso às dissertações. Foram utilizados 30 (trinta) artigos, 15 (quinze) livros, 3 (três) trabalhos acadêmicos e 1 (um) material digital com imagens e textos.

A análise dos materiais foi realizada de acordo com os objetivos a serem alcançados, portanto, cada artigo, livro ou trabalho acadêmico foi recolhido e analisado a fim de atingir os objetivos deste estudo.

Para inclusão dos materiais da pesquisa, foram considerados obras clássicas e novas que permitem comparações e mesmo um corpo sólido à pesquisa. Os idiomas dos textos não foram delimitados, cabendo ao pesquisador discriminar a relevância da obra para sua utilização na pesquisa. 0 número de materiais utilizados em língua estrangeira foi de apenas um.

Não foi estabelecido um período do tempo como limite de data para a utilização dos materiais, tendo sido o único critério de uso a relevância para a pesquisa. 


\section{RESULTADOS DE DISCUSSÃO}

\section{A relação homem x trabalho}

Ao longo do tempo, a relação do homem com o trabalho sofreu alterações importantes, a dinâmica do trabalhar e o "realizar algo" variaram de acordo com o tempo e contexto em que estavam inseridas, pois diferentes culturas atribuem diferentes significados ao trabalho. No contexto grego, o trabalho era associado primeiramente à sobrevivência, como afirma Bendassolli (2011), era um meio de manutenção da espécie. O poeta grego Hesíodo, por sua vez, salientava a dupla definição de trabalho, sendo o "érgon" (trabalho criativo) e o "ponos" (labuta sofrida) (BITTENCOURT, 2010), porém, no mesmo contexto havia uma outra concepção, que era o trabalho manual, o artesanato, tendo também a filosofia e as artes (BENDASSOLLI, 2011), obviamente, aos que podiam.

De acordo com Bendassolli (2011), parte desse pensamento se perpetuou. A arte e a filosofia foram preservadas, entretanto, o trabalho já não era somente para a sobrevivência, mas também para o cultivo da alma (BENDASSOLLI, 2011). Nos primórdios da Idade Média, a relação que o homem tinha com o trabalho era a partir de um senso religioso que guiava aquele contexto, graças ao monaquismo, estilo de vida que pregava a contemplação, oração, penitência e trabalho.

Dois dos grandes nomes do monaquismo são, Santo Agostinho, filósofo e bispo da Igreja Católica e São Bento, criador da Ordem de São Bento (OSB), ou Beneditinos. De acordo com Aquino (2009), Santo Agostinho criou um modo de viver que inspirou as diversas famílias religiosas, e pode-se dizer que a sociedade em geral daquele contexto. 0 próprio escreveu o folheto "De opere monachorum", que significa "sobre o trabalho dos monges" (AQUINO, 2009), este opúsculo se baseava nos dizeres do Apóstolo São Paulo, "quem não quer trabalhar, que não coma" (AQUINO, 2009).

Isto se aproxima do conceito de "Ora et Labora", lema da Ordem de São Bento (OSB), que em sua tradução significa "rezar e trabalhar". Era este o estilo de vida dos monges e pilar da vida monástica, como afirma Dias (1998), e que São Bento sublinhava a importância do trabalho, trabalho físico, manual, que era desprezado pelos romanos (DIAS, 1998).

A partir disso, é possível identificar a função do trabalho para os monges, era muito mais do que a simples realização do serviço para a sobrevivência, mas também a preservação das virtudes contra os males espirituais, que de acordo com Bendassolli (2011), o monge trabalhava para evitar o ócio e o tédio. Ora, para quem assim deseja fugir da ociosidade, que para os monges significa um prato cheio para a tentação, o trabalho era a melhor solução.

Saindo do período medieval, entrando nos tempos modernos, têm-se duas visões acerca do trabalho que são opostas, mas possuem algo em comum. 0 trabalho no contexto nórdico e no contexto latino. De acordo com Demo (2006) o trabalho nos países nórdicos é visto de forma positiva, como um desejo de realizar algo produtivo e que portanto, acrescentaria diretamente um significado à vida de quem o exerce (DEMO, 2006). Entretanto, no contexto latino, o trabalho por vezes é visto de forma sacrificante, por vezes como um castigo (DEMO, 2006), e é exercido com insatisfação, porém, não necessariamente isento de sentido. Glina e Rocha (2012) afirmam que o trabalho sempre foi conflituoso, e fazem uma referência à bíblia ao dizer que o homem foi sentenciado a comer o pão com o suor do próprio rosto (GLINA; ROCHA, 2012), com isso, significa dizer o trabalho seria a condição primária da existência humana. Do mesmo modo que França e Rodrigues (2009) corroboram com tal pensamento, ao considerarem que os primeiros a habitarem a terra receberam o castigo de trabalharem para se manterem.

A similaridade dessas ocupações nos diferentes contextos está na realização do serviço, embora seja realizado pela dor ou prazer, ainda assim é realizado. Posteriormente será visto o papel da motivação da execução do trabalho e como o homem busca realizá-lo de forma a dar sentido à sua existência.

O psicanalista canadense Peterson (2018) faz uma analogia acerca do trabalho também a partir de uma referência bíblica, que de certo modo corrobora com toda visão ocidental do trabalho. Ele entende o trabalho como consequência da queda do homem, de sua fraqueza, portanto, de seu pecado. E esta fraqueza humana levou o homem a compreender algumas de suas características fundamentais, a vulnerabilidade e a morte (PETERSON, 2018). 0 trabalho portanto, adiaria o fim, e pelo sacrifício do serviço se teria os benefícios da vida eterna. Veja que essa visão que acabou por moldar a civilização ocidental, ainda é presente até os dias atuais. 0 trabalho possui uma característica de tornar o ser humano digno de algo, seja para ele temporal ou eterno, é por meio da obra e/ou ação que ele poderá desfrutar de seus próprios anseios (PETERSON, 2018; ARENDT, 2008 Apud MIGUEZ, 2015). Como bem afirma Codo (1997), o trabalho é a forma do homem atribuir significado à natureza, esta característica seria algo completamente humano, não podendo ser transferida ao animal, por exemplo. 
É válido afirmar que por meio do trabalho, o homem é submetido a todo tipo de estímulos estressores, como bem afirma França e Rodrigues (2009) no entanto, mesmo com estes estímulos, o homem assim o exerce, pois esse mesmo trabalho pode ser fonte de satisfação e realização (FRANÇA ; RODRIGUES, 2009). Diante disso, as ideias levantadas sobre o trabalho permitem questionar que, seja por dor ou prazer, como o ser humano lida com o trabalho? Desde a labuta fatigante até o trabalho criativo.

\section{A natureza humana do trabalho}

De forma clara e objetiva, o homem exerce seu trabalho, podendo a este ser atribuído significado positivo ou negativo. Prazer e sofrimento são resultados do trabalho. Glina e Rocha (2012) trazem a etimologia da palavra "trabalho", que na língua latina se origina de tripalium, um objeto de tortura. Do idioma grego origina-se work, no inglês, advindo de érgon, e tem-se o alemão werkam, que pode ser entendido como jogos ou diversão (GLINA; ROCHA, 2012).

Codo (1997) ao citar da obra de Friedman e Neville (1962) "Tratado da sociologia do trabalho", considera o trabalho como uma característica da espécie humana. Embora não seja propriedade única e exclusivamente dos seres humanos, pois os animais trabalham, porém por eles não é atribuído significado algum em suas práticas. Para Pinheiro e Monteiro (2007), o trabalho constitui um sentido na vida para muitas pessoas, visto que alguns passam até mais tempo em suas atividades profissionais do que fora delas.

Arendt (2005) utiliza dos termos para tratar da condição humana acerca do trabalho, animal laborans e homo faber, que trata da relação do homem com a ocupação, seja ela a sofrida labuta ou o trabalho criativo e prazeroso. Se pretende fazer uma comparação dos dois termos utilizados por Arendt (2005) com a visão do psiquiatra Viktor Frankl sobre o trabalho e a importância que ele estabelece na vida do homem. Portanto, neste capítulo será abordada a visão Frankliana do homem e sua ocupação, fazendo um comparativo com os conceitos de animal laborans e homo faber de Hannah Arendt.

Hannah Arendt na sua obra "A condição humana" afirma que esta condição está ligada ao que a toca ou a relação duradoura que é desenvolvida com ela (KONRATH, 2014). A condição humana não é somente desenvolvida pelas coisas naturais, mas também pela vida ativa do homem, que a nenhum é possível escapar, pois faz parte da natureza humana (ARENDT, 2005). A vida ativa consiste na labuta, o trabalho e a ação (KONRATH, 2014). É possível notar que há portanto, uma diferença entre labor e trabalho. Miguez (2015, p.132) salienta que

o trabalho corresponde à criação da vida artificial, à criação de artefatos, e por isso não tem finalidade em si mesma, como meio que é para se construir um objeto, algo distinto da atividade da mesma: "a condição humana do trabalho é a mundanidade.

Fiorati (1999) partindo da mesma perspectiva de Arendt, revela que o labor, aquilo que Hesíodo chamava de ponos, é a condição do ser se manter vivo. Utiliza-se o conceito de animal laborans, que é o animal que trabalha. Consiste em dizer que é o homem que trabalha para sobreviver e esta é uma característica inerente do corpo humano. Há o conceito de homo faber, que por sua vez, consiste no homem que trabalha criando (FIORATI, 1999). No entanto, como visto, esta criação não se justifica em si mesma. Estas definições assemelham-se ao que na Grécia antiga conheciam como érgon e ponos.

De acordo com Correia (2013) a vida humana é nutrida pelo trabalho, ele traz em sua obra o mesmo pensamento de Arendt ao falar sobre a vida ativa do animal laborans. 0 próprio ato de viver é trabalhoso e o animal laborans está condicionado biológicamente a realizar o trabalho (CORREIA, 2013). É o que afirma também Arendt (2005) ao dizer que não é possível escapar de tal condição, pois é natural. Embora para alguns autores a condição do homem que trabalha para sobreviver, sendo este o conceito de animal laborans, seja natural e livre de qualquer possibilidade de escapatória de tal condição, não parece ser uma perspectiva propriamente humana, pelo contrário, escraviza o homem e o aprisiona em uma condição da qual parece um tanto quanto contraditória.

Tal concepção enxerga o trabalho apenas como um meio de sobrevivência para o animal laborans, como afirma Correia (2013 p. 210)

a atividade do trabalho não humaniza, não singulariza nem transcende a necessidade sem o auxílio da capacidade reificadora do homo faber, hábil na produção de objetos, dentre os quais cabe destacar as ferramentas e os 
instrumentos que vêm ao auxílio do animal laborans em sua liberação do aprisionamento ao imperativo da necessidade.

Esse é um ponto relevante, pois somente o homo faber, ou seja, a visão do homem produtor, a mesma que Hesíodo tinha sobre o ponos, o trabalho criativo, que o homem é capaz de produzir seus instrumentos e ferramentas, além de um simples desejo sobrevivência (CORREIA, 2013).

A ideia de um ser não transcendente parece ser uma impossibilidade para Frankl (2018) que afirma que trascender a si é a essência do ato de existir. Frankl mesmo já alertara sobre o valor do trabalho para a construção de um sentido para a vida, e que para ele nada existe que capacite tão bem o ser humano para a superação de dificuldades como a consciência de se ter uma tarefa a cumprir (FRANKL, 2018).

0 animal laborans portanto iria de encontro com o entendimento de Frankl, que discordara de um ser humano condicionado e sem capacidade de transcendência, entretanto, o homo faber, poderia talvez, ter similaridades com o entendimento do psiquiatra austríaco sobre o ser humano e sua relação com o trabalho, pois o trabalho ultrapassa a questão da simples sobreviência.

Poderia até certo ponto, se analisado de forma rasa e superficial, pois Kroeff (2011) destaca um ponto chave da teoria de Viktor Frankl, que é o conceito de autotranscendência. Significa dizer que o homem transcende a si mesmo ao "sair de si" e se orientar a algo ou alguém (KROEFF, 2011), desta forma, o trabalho seria um meio de transcender-se. Entretanto, o trabalho do homo faber nesse ponto, em nada se parece com o homem transcendente de Frankl, pois como bem afirma Arendt (2005)

A perplexidade do utilitarismo, que é a filosofia do homo faber, por assim dizer, é que ele fica aprisionado na cadeia sem fim dos meios e dos fins sem jamais chegar a algum princípio que pudesse justificar a categoria, isto é, a própria utilidade. (p. 189)

Desse modo, é possível compreender como a noção de homo faber diverge do conceito de homem transcendente de Frankl, pois para o psiquiatra austríaco, o homem não está aprisionado em sua tarefa, mas utiliza-se dela como um meio de se obter sentido à sua existência (FRANKL, 1987).

\section{0 animal, o humano e o direcionamento ao sentido pelo trabalho}

Em meio às diferentes abordagens sobre a condição humana do trabalho, fatores que levam o ser ao sentido, a essência de sua existência e tantas outras condições que permitem a comparação do homem com o animal, há uma analogia que parece um tanto quanto esclarecedora a respeito.

Uma formiga por exemplo, não consegue, devido à sua natureza, depositar sentido ao recolher pedaços de folhas, embora o faça com maestria. Pois não é próprio da formiga esta característica, mas é próprio dela recolher os pedaços de folhas. Peterson $(2018$, p. 208) utiliza a mesma analogia com castores, ao assim dizer

Às vezes os animais agem como se estivessem trabalhando, mas apenas estão seguindo os ditames de sua natureza. Castores constroem barragens. Fazem isso porque são castores, e castores constroem barragens. Enquanto estão construindo uma represa, eles não ficam pensando: É, mas eu preferiria estar nas praias do México com a minha namorada.

De modo descontraído e com um senso literário, Peterson (2018) na verdade distingue a capacidade de atribuir um sentido no serviço, sendo essa uma característica propriamente humana. Desse modo, ao ser humano é dada a oportunidade de depositar sentido em quaisquer que sejam as atividades desenvolvidas. Como dito por Frankl (1987), a busca do sentido é a motivação principal do homem, sendo somente dele a responsabilidade para encontrá-lo.

Nota-se que o trabalho também possui uma característica determinante de identificar o indivíduo a partir dele. Como foi possível observar, os animais são identificados pelas suas atividades, e ao homem isto também se encaixa.

A analogia presente no texto de Peterson (2018) ao citar os castores, faz com que seja possível direcionar isto ao ser humano, torna-se vísivel a identidade dos povos a partir do trabalho. Segundo Torres (2007), na etnia Ticuna, os índios possuem um papel a desenvolver. Ao atingir a menarca, à mulher é ensinado artesanato, pois entende-se que para casar precisa saber produzir as louças e os demais materiais. Ao 
homem isto também vale, é ensinada a caça e a pesca, pois se não o souber realizar, não está preparado para o casamento (TORRES, 2007).

É interessante notar que o trabalho neste contexto possui a característica de dar valor à existência humana, ora, se tal pessoa não exerce tal função, há a possibilidade de sentir-se não pertencente daquela tribo, não havendo sentido em sua vida.

Um dado interessante é que o Enriquez (2014) não considera o trabalho como algo propriamente humano, alegando que as sociedades arcaicas trabalhavam pouco (ENRIQUEZ, 2014), e de fato tem razão. 0 trabalho não é algo humano, pois como visto, os animais executam diferentes formas de trabalhos. Entretanto, este mesmo animal, não tendo racionalidade alguma, não poderá de nenhum modo achar no trabalho um próposito para se viver, pois isto sim é exclusivamente humano.

A característica humana presente na execução de um serviço, não está necessariamente em sua execução, mas sim na motivação do homem ao realizar seu trabalho. Toda alegria e frustração advinda do trabalho são humanas, o que diferencia nesse aspecto, do trabalho realizado pelos animais.

\section{Influência do trabalho na saúde mental}

\section{0 trabalho como meio de dar sentido à vida}

De acordo com Enriquez (2014), o trabalho por muito tempo foi considerado quase como uma obrigação do ser humano, por muito tempo foi visto como uma forma de dignificar o homem. No entanto, é comum que a noção de trabalho seja vista de forma cansativa, seja por insatisfação ou outro motivo qualquer. Partindo desse ponto será possível investigar como para alguns autores isto dignifica o homem. Ou melhor, como isto dá sentido a vida do homem.

0 primeiro ponto a ser considerado na realização do trabalho, é a motivação do indivíduo, a força que o homem deposita para a realização de algo. Zanelli (2014) afirma que a motivação é um processo psicológico básico, se trata da ação quando dirigida a algo, relacionada a vontade, portanto dependente do interesse do ser humano. 0 sentido no entanto, está diretamente ligado à motivação. Já para Frankl (1987), a busca de sentido é a motivação principal para o homem, sendo de total responsabilidade deste de encontrar um sentido para sua vida e então satisfazer-se. Para este teórico, é possível encontrar sentido por três vias

Criando um trabalho ou praticando um ato; 2. experimentando algo ou encontrando alguém; 3. pela atitude que tomamos em relação ao sofrimento inevitável. A primeira, o caminho da realização, é bastante óbvia. A segunda e a terceira necessitam de uma melhor elaboração (FRANKL, 1987, p.76).

0 trabalho é o primeiro ítem citado por Frankl, que diz que é óbvia sua contribuição para a busca de sentido. Dessa forma este capítulo propõe-se a investigar como o ser humano passa a ter um sentido na vida a partir do trabalho.

Dall'Bello (2019) considera que os sentidos e significados advindos do trabalhos constituem uma construção multidimensional, pois derivam da interação do sujeito com o ambiente de trabalho a qual estão inseridos. Neste contexto, a possibilidade de troca de experiências, interesses e valores surge com naturalidade, havendo uma interação sadia e que contribui para a saúde mental do sujeito, e logicamente para a manutenção da organização. Nesse ponto, concorda também Zanelli (2010), ao assim afirmar que as atividades de trabalho que são dotadas de sentido, podem ser vistas com pontencial emancipador, se for coerente com o conjunto de valores do de quem o exerce. Sendo assim, o trabalho tem a capacidade de agregar positivamente à vida do sujeito, partindo do pressuposto de que lhe foi atribuído um sentido para ser realizado.

Correlacionando com o conceito anteriormente citado do animal laborans, o trabalho é uma condição fundamental para o homem, é por meio deste que há uma interação com a natureza, grupos e gera função social (DALL'BELLO, 2019), é também o meio pelo qual se sobrevive. Analisando o que Frankl diz a respeito do trabalho, faz-se necessário pensar o motivo do trabalho ser tão importante assim para dar sentido à vida do homem, de modo mais claro, se o trabalho tem a capacidade de significar algo ao ser humano, por que o homem sofre no ambiente de trabalho?

0 adoecimento pelo trabalho se dá por inúmeros fatores que serão abordados posteriormente, no entanto, é preciso compreender que para Frankl, o homem é capaz de dar sentido à sua vida mesmo em situações adversas, pois é uma característica do ser humano, logo, em ambientes de trabalho com condições 
precárias, ainda assim ao ser humano seria possível atribuir sentido frente a esse sofrimento. Isso implicaria dizer que

Não devemos esquecer nunca que também podemos encontrar sentido na vida quando nos confrontamos com uma situação sem esperança, quando enfrentamos uma fatalidade que não pode ser mudada. Porque o que importa, então, é dar testemunho do potencial especificamente humano no que ele tem de mais elevado, e que consiste em transformar uma tragédia pessoal num triunfo, em converter nosso sofrimento numa conquista humana (FRANKL, 1987. p. 77).

Um trabalho desgastante, sofrido, poderia por sua vez ser um meio para o homem dar sentido à sua vida, a partir do momento que o homem se doa por algo, há o que Frankl (2018) chama de transcendência, com isso o ser humano se direcionaria a um sentido, algo a se realizar, ou seja, seu trabalho.

\section{O sofrimento a partir do trabalho}

Mens sana in corpore sano. Esta frase em latim significa dizer "mente sã e corpo são", é compreensivél supor que a mente quando sadia permite ao corpo estar sadio também. A mesma frase deve ser aplicada ao contexto do trabalho, não obstante, assim não a seja.

Salvador e Filho (2011) afirmam que viver com dignidade necessita de vida saudável, integridade e um trabalho que permita integração social de qualidade, porém não é isso que se vê. Mesmo passando o período da revolução industrial, o trabalho exploratório e cansativo ainda é presente. Desse modo, o sofrimento, seja ele psiquíco ou corpóreo pode se manifestar, e da mesma forma que a mente sã contribui para o corpo são, o corpo enfermo contribui para uma mente enferma, aeger mens corpus infirmum.

De acordo com Zanelli (2010) a sociedade da pós-indústria, na constante demanda por adaptações, acaba por exigir certas reações do sujeito que por vezes prejudicam a sua racionalidade e extirpam a saúde daqueles que têm dificuldades para enfrentar pressões

Com isso, Zanelli (2010) quer dizer que por meio das mudanças no ambiente de trabalho, o homem é constantemente exigido, no entanto, por vezes não é capaz de suportar as pressões advindas das transformações neste meio, causando assim, sofrimento ao trabalhador.

Lhulier (2009) apud Bendassolli (2011) aponta os modos de sofrimento no trabalho, que são divididos em três categorias, são elas: patologia de atividades impedidas, patologias de solidão e patologias de violência. Não que esses sejam os únicos modos de sofrimento no trabalho, porém a partir deles será possível compreender como a relação do homem com o trabalho pode ser em muitos casos causadora de dor. As atividades impedidas para Lhulhier (2009) apud Bendassolli (2011) dizem a respeito da sobre-carga no trabalho, o estresse e burnout entrariam nesta categoria. 0 clima que o trabalho proporciona influencia na saúde do trabalhador, qualquer situação em que não há controle no trabalho pode vir a causar desconforto e problemas à saúde do indivíduo, como afirma Giannini et al (2012).

Ainda abordando a questão dos problemas advindos do trabalho em condições ruins, Heloani e Capitão (2003), alertam para um fator importante e que:

$\mathrm{Na}$ realidade, ao contrário do que muitos possam supor, a organização do trabalho não cria doenças mentais específicas. Os surtos psicóticos e a formação das neuroses dependem da estrutura da personalidade que a pessoa desenvolve desde o início da sua vida (p. 102).

Desse modo é possível supor que o trabalho não necessariamente causa certas patologias, mas pode ser um ambiente propiciador e atuar como gatilho para certas limitações na vida do indivíduo devido ao nada incólume contexto de trabalho.

Outra categoria que Lhulier (2009) apud Bendassolli (2011) cita em seu estudo, se trata das patologias de solidão, que consiste na individualização das ações no trabalho, prêmios por metas individuais, trabalhos por setores, perdendo por sua vez a coletividade na execução das tarefas. Já a terceira e última categoria diz respeito à violência e maus tratos no ambiente de trabalho. Neste caso é verificada relação de poder entre os superiores e subordinados, e que vence quem for mais forte (BENDASSOLLI, 2011), obviamente se sabe quem é o mais forte em uma hierarquia. 
O sofrimento no trabalho é causador de dor, seja física ou psiquíca, De Barros e De Barros (2007) ao analizarem as obras de Dejours sobre saúde e trabalho, fazem a seguinte constatação: de que o trabalho prazeroso é aquele em que o trabalhador é parte essencial de sua produção, e que o sofrimento e a dor advém em decorrência do sentimento de inutilidade e desqualificação por não usufruirem de suas habilidades criativas. 0 mesmo fator que Dall'Bello (2019) afirmara ao dizer que

no modelo capitalista o trabalho descaracteriza a imagem de ser um artesanato, uma obra do homem, uma extensão de si e a projeção de sua criatividade. 0 homem não participa mais do destino que é dado ao seu trabalho, não vê mais o produto final, não se sente criador de sua obra (p. 26).

Este fator acaba por impactar a vida do trabalhor que pode não reconhecer seu trabalho, afinal, nem mesmo o produto nas mãos dos clientes ele vê, pois a execução das tarefas são divididas por setores.

O ponto a se destacar nas formas de sofrimento elencadas acima está na compreensão de mudança no trabalho. 0 trabalho em conjunto passa a ser um trabalho individual, separado por setores, com chefes em cada setor, com pouca integração, trabalhos repetitivos, etc. Backes (2012) alerta sobre o desprezo às ações individuais e a competitividade exacerbada leva o trabalhador ao sofrimento, contribuindo com a ideia de Flach (2009) que afirma que a competição e as mudanças no trabalho aumentam as chances de sofrimento por parte do trabalhador. Este sofrimento se manifesta de diversas formas possíveis, causando estresse, e varia de pessoa para pessoa.

\section{O desgaste da labuta: estresse e burnout}

Estresse advém da física, e siginifica quão deformado está um corpo quando então é submetido a grandes esforços (FRANÇA; RODRIGUES, 2009). O estresse, portanto, é a resposta do indivíduo frente a um estímulo que causa tensão e excitação emocional (HONORATO; MACHADO, 2019), como dito anteriormente, essa resposta irá variar de pessoa para pessoa, pois o estímulo não é recebido da mesma forma por todos, embora sejam eventos estressores similirares. Sendo o estresse a reação do organismo a um evento causador de excitação, torna-se possível compreender que o estresse não necessariamente é algo negativo, embora seja automaticamente associado a isso pelo senso comum, é o que afirmam Calais, Andrade e Lipp (2003) Apud Noronha e Fernandes (2008).

As concepções errôneas acerca da palavra acabam por se generalizar até mesmo no meio científico, para Vieira e Russo (2019) o estresse é amplo e seu significado está presente tanto na população geral, quanto no meio científico, contudo, se tratando do estresse laboral, ou seja, o estresse em decorrência do trabalho, se delimita e é utilizado o termo burnout que em sua tradução literal siginifica "combustão completa" (VIEIRA; RUSSO, 2019), o termo também é compreendido como explosão. Desse modo, o estresse laboral, entendido como burnout seria o desgaste físico e emocional do sujeito no ambiente de trabalho. França e Rodrigues (2009) darão uma afirmação concisa acerca do burnout, que é fruto de situações de trabalho. Uma reação emocional a situações de estresse no trabalho (FRANÇA; RODRIGUES, 2009).

Vieria e Russo (2019) explicam as características da síndrome de burnout, nesses casos há exaustão emocional; despersonalização ou cinismo e baixa realização pessoal. Tais característica não surjem abruptamente, leva-se um tempo para que o acúmulo de eventos estressores fermentem para que aja a combustão (burnout), se é permitido a analogia. Com o burnout, há a incapacidade de voltar a desempenhar tal função com êxito como anteriormente, não havendo sentido algum na tarefa a ser realizada, com isso, atividades impostas ao trabalhador que por sua vez, não consegue vislumbrar sua finalidade colocam em risco sua sanidade mental (ZANELLI, 2010).

Um estudo realizado por Melek (2017) com mineradores, analisou as condições de trabalho na qual eles estavam inseridos e apontou fatores que pontencialmente causariam danos a vida do trabalhador. 0 alto grau de risco do trabalho nesses casos pode por si só gerar ansiedade no sujeito e lhe causar tensão, mesmo sem estar a exercer sua função. Além dos possíveis danos, foram listadas doenças decorrentes da função destes trabalhadores, como distúrbios pulmonares, dificuldades respiratórias, tosse e sensação de sufocamento (MELEK, 2017) Apud (NERY et al., 2009; LOYOLA et al., 2010; GRABER et al., 2012; MORB, 2012; REY; ROSALES, 2012; KNIGHT et al., 2015; CABRAL; PEREIRA; ALVES, 2012).

Embora este caso citado esteja tratando de uma profissão específica, o estresse não está presente unicamente nestas condições, mas em qualquer outra atuação do indivíduo, sejam distúrbios na voz em professores, como bem analisado por Giannini et al (2012) ou a sobrecarga em profissionais da saúde, traballho realizado por De Marco et al (2008). 
Outro fator que merece destaque na questão do sofrimento pelo trabalho, é o estresse a partir da elevada tensão devido à grandes exigências e baixo controle (ZANELLI, 2010). Com baixo controle, Zanelli (2010) refere-se à insegurança a respeito da permanência em tal emprego e as condições de trabalho.

\section{A visão da psicologia na relação homem x trabalho}

Para Zanelli (2014), a psicologia do trabalho constitui-se de uma preocupação para além da organização, sobretudo para as questões de saúde do trabalhador, pois uma vez doente, atingiria todo o funcionamento organizacional.

No Brasil, a psicologia do trabalho nasce no período de redemocratização, na década de 80 , fase de abertura política e com a forte presença dos sindicatos e movimentos com ênfase na saúde do trabalhador (ARAÚJO; BARROS, 2019). A presença de psicólogos e demais profissionais da saúde em órgãos sindicais aumentou a visibilidade desta área e contribuiu para sua expansão, que tem por interesse compreender e lidar com questões relacionadas ao comportamento humano e sua interação no ambiente de trabalho (ZANELLI, 2014). A partir disso, o modo como o homem se relaciona no trabalho e a partir do trabalho se torna objeto de estudo psicologia do trabalho.

Anos mais tarde, com o advento das tecnologias e mudanças no trabalho, é compreendido que tais mudanças tecnológicas implicam diretamente na saúde do trabalhador (ELIAS; NAVARRO, 2006). Com a atualização dos serviços e as adequações às necessidades da sociedade conteporânea, ocorre mudanças na organização, tais mudanças permitem identificar como os trabalhadores lidam com as transformações organizacionais e a influência disso em seu comportamento. A partir da luta pela saúde do trabalhador e as mudanças no ambiente de trabalho, a prática do psicólogo começa por se diferenciar da área clínica, havendo uma divisão entre psicologia clíncia e psicologia da saúde (ARAÚJO; BARROS, 2019).

Estas transformações no trabalho levaram Ribeiro e Leda (2018) a questionarem as repercussões das mudanças na subjetividade do trabalhador e como o trabalhador tem enfrentado o processo de intensificação do trabalho. Ribeiro e Leda (2018) afirmam que as mudanças no trabalho estabeleceram vínculos empregatícios mais fracos e relações frouxas, e que diante de tais circustâncias, o trabalhador busca qualquer meio para sobreviver (RIBEIRO; LEDA, 2018). Para casos como esse, Trindade (2012) afirma que atuação da psicologia na empresa é também de identificar os comportamentos desadaptativos, afim de preveni-los com antecedência. 0 psicólogo do trabalho iria investigar os fatores determinantes para o sofrimento e comportamentos desajustados na organização, além de considerar as características positivas que contribuem para a manutenção de um sentido de vida e valor social do trabalho na vida do trabalhador.

\section{Valor social a partir do trabalho}

Seguindo a analogia de Peterson (2018) e Torres (2007) ao citar as atividades que dão identidade aos povos da etnia ticuna, é possível a partir disso compreender outra característica importante do trabalho, que é do papel social nele presente.

Sampaio e Galasso (2009) ressaltam fatores ambientais ligados ao trabalho ao mencionar um estudo acerca do estresse no ambiente de trabalho. Um desses fatores presentes no estudo diz respeito ao papel do trabalhador na organização e sua identificação com sua função exercida.

Schimidt (2010) realizou um estudo que leva em consideração o valor social do trabalho, como este dá sentido e identidade à vida do homem, por meio da perspectiva sociodramática de Levy Moreno. Nesse estudo, um dos pontos importantes sobre o papel desenvolvido pelo trabalhador no ambiente laboral e que não é considerado saudável, é a padronização do trabalho. Os exemplos de profissões que padronizam sua atuação é a de comissário de bordo e atendente de telemarketing, que devem transmitir segurança e um certo grau de felicidade e satisfação, mesmo que não estejam vivendo isso (SCHIMIDT, 2010). Desse modo, o trabalhador não desempenha o papel que deseja, o que acaba por transmitir uma emoção artificial, propiciando adoecimento (SCHIMIDT, 2010). Esta situação tem ligação com o que relatam Sampaio e Galasso (2009) ao citarem os estudos sobre estresse laboral, pois o trabalhador pode por vezes não se identificar com sua função. Para muito além do papel exercido pelo trabalhador, no processo de produção, o homem influencia e se deixa influenciar pelo trabalho, como afirma Zanelli (2010), desta maneira, há uma relação de troca entre o homem e o trabalho do qual exerce. 
Fischer et al (2003) apud Schimidt (2010) menciona os problemas de trabalhadores noturnos, por exemplo, pois têm a possibilidade participar de eventos reduzidas, bem como menos momentos com a família, gerando dificuldades no convívio, do mesmo modo que Pinheiro e Monteiro (2007) citam sobre os trabalhadores que passam por vezes mais tempo em seu trabalho do que no âmbito familiar. Há também a questão de que diversos trabalhadores estão levando consigo problemáticas vinculadas ao ambiente de trabalho, e ocupando seu tempo com tais questões (ZANELLI, 2010), esta forma de trabalho pode se tornar prejudicial para o relacionamento interpessoal do indivíduo.

Partindo agora de um evento atual, o ano de 2020 foi um ano atípico para a população mundial em vista da pandemia do novo coronavírus, porém, a pandemia trouxe consigo um novo olhar acerca do trabalho, considerando que além das perdas humanas, os impactos no nível econômico continuam a acontecer (GIL, 2020). Com isso, o trabalho neste período de quarentena e lockdown viu-se flexibilizado ou até paralizado em alguns casos, o que afeta diretamente ao trabalhador também.

Pedrozo (2016) apresenta a noção de trabalho como fenômeno da existencialidade humana e dignificador de quem o executa. Essa perspectiva não dignifica somente o trabalhador, pois não interfere somente em sua vida privada, afinal o indivíduo não é um ser de relações particulares, intrapessoais, mas sim interpessoais, influenciando portanto, diretamente no seu contato com os demais, em especial sua família. 0 emprego atualmente perdeu espaço no seu campo formal e regulamentado, abrindo caminho para o emprego informal, é o que diz Montali (2003) ao afirmar que houve uma piora na qualidade do trabalho, e que o emprego industrial passou a ser substituído por ocupações autonômas. E continua afirmando que

[...] a reestruturação produtiva e o baixo nível de atividade econômica elevaram as taxas de desemprego e promoveram precarização das relações de trabalho (MONTALI, 2003. p. 125).

Tal afirmativa permite considerar que embora o trabalho tenha mudado ao longo do tempo, o que é normal, ainda assim há a compreensão de que realizá-lo é assumir um papel de dignidade perante a sociedade.

\section{CONSIDERAÇÕES FINAIS}

A discussão realizada possibilitou compreender o papel do trabalho na vida do ser humano, pois tanto suas características positivas, quanto negativas, apresentam certa influência no pensar e no agir do indivíduo, tendo grande efeito nos apectos físicos e psicossociais.

Pôde ser constatado que o modo como o homem lida com as atividades diárias do trabalho estão ligadas também ao contexto em que o mesmo está inserido, em virtude dos diversos determinantes que contribuem para a constituição pessoal de cada indivíduo e a cultura de cada local. Embora se tenham variadas compreensões sobre o trabalho, é evidente que da mais antiga era até a contemporaneidade, o trabalho sempre se apresentou como uma forma de dignificar o homem em sua vivência. Por mais doloroso e sofrido que seja, é possível encontrar pessoas que se orgulham por ter uma tarefa a ser realizada diariamente, pois é a custa disso que vivem, tanto no sentido material, de adquirir recursos para sobreviverem, quanto no sentido mais particular, aos que consideram o trabalho uma forma de dar valor à vida.

Entende-se que seria de grande valia para os estudos nessa área, ao abordar os efeitos do trabalho na vida do indivíduo, considerar a visão da própria pessoa sobre o ato que está realizando, pois se há uma motivação para a realização das tarefas, torna-se claro que as consequências serão sentidas de modo diferente aos que não possuem tal motivação. No entanto, cabe ressaltar que o trabalho não é somente uma máquina de distribuir dor e sofrimento, na verdade, o trabalho em si não possui essência, pois os aspectos desta atividade serão dispensados a partir da singularidade de quem o exerce. 0 ofício não pode ser tido como bom ou ruim por sua natureza, é pelo oficiante que o trabalho adquire caráter criativo e realizador ou doloroso e desesperador.

Salienta-se também que o estudo e a aplicação das teorias do trabalho no campo da psicologia, não podem estar voltadas somente à produtividade e ao mercado, contudo, ao produtor e o modo como ele se relaciona com sua atividade diária. É a partir disso que consegue-se compreender que antes da mercadoria e organização, há uma pessoa que executa seu trabalho e necessita de uma atenção própria. 0 entendimento da psicodinâmica do trabalho permite ao profissional analisar cada fator e atuar de forma mais eficaz nos campos de gestão de pessoas, saúde ocupacional, ergonomia e antropologia.

De modo mais particular, a execução deste trabalho possibilitou uma compreensão mais ampla acerca do assunto, contribuindo para o amadurecimento intelectual deste. A busca por materiais foi relativamente 
fácil, visto que o tema possui uma gama de trabalhos já desenvolvidos, embora sempre com específicidades distintas.

\section{REFERÊNCIAS}

[1] ARAÚJO, José Newton Garcia de; BARROS, Vanessa Andrade de. Psychology and the work clinics in Brazil. Laboreal, Porto, v. 15, n. 2, p. 1-13, dez. 2019.

[2] ARAUJO, Luciana Danielli de et al. Pesquisa bibliográfica, estratégias de buscas e fontes de informação, conceitos e abordagens. Apresentação de PowerPoint. 2020.

[3] ARENDT, Hannah. Trabalho, obra e ação. Cadernos de Ética e Filosofia Política 7, p. 175-201. 2005.

[4] AQUINO, Felipe Rinaldo Queiroz de. Uma história que não é contada. 5a ed. Lorena: Cléofas, 2009.

[5] BACKES, Airton Luiz. Trabalho e subjetividade: sofrimento psíquico em contexto de mudanças organizacionais. Gestão e Sociedade, v. 6 , n. 14, p.117-138. 2012.

[6] BENDASSOLLI, Pedro F. Mal-estar no trabalho: do sofrimento ao poder de agir. Revista Mal-estar e Subjetividade - Fortaleza, v. 11, n. 1, p.65 - 99. mar. 2011.

[7] BITTENCOURT, Renato Nunes. 0 valor sagrado do trabalho em Hesíodo. Revista espaço acadêmico. n. 109. Jun. 2010.

[8] CODO, Wanderley. Um diagnóstico do trabalho (em busca do prazer). Trabalho, organizações e cultura, c. 3. p.41. 1997.

[9] CORREIA, Adriano. Quem é o animal laborans de Hannah Arendt?. Rev. Filos., Aurora, Curitiba, v. 25, n. 37, p. 199-222, jul./dez. 2013.

[10] DALL'BELLO, Camila. Vida e sentidos na perspectiva de Viktor Frankl: um estudo sobre o sentido da vida e do trabalho na atualidade. Universidade de Passo Fundo. Passo Fundo, 2019.

[11] DE BARROS, Regina Benevides; DE BARROS, Maria Elizabeth Barros. Da dor ao prazer no trabalho. Trabalhador da saúde: muito prazer, p. 61-71, 2007.

[12] DE MARCO, Patrícia Furuta et al. O impacto do trabalho em saúde mental: transtornos psiquiátricos menores, qualidade de vida e satisfação profissional. Jornal Brasileiro de Psiquiatria., Rio de Janeiro , v. 57, p. 178-183, 2008.

[13] DEMO, Pedro. Trabalho: sentido da vida!. B. Tec. Senac, Rio de Janeiro, v. 32 , n.1, Jan/Abr., 2006.

[14] DIAS, Geraldo J. A. Coelho, OSB. Ora e Labora: a procura da origem da divisa Beneditina. Universidade do Porto. Hvumanitas - v. 50, 1998.

[15] ELIAS, Marisa Aparecida; NAVARRO, Vera Lúcia. A relação entre o trabalho, a saúde e as condições de vida: negatividade e positividade no trabalho das profissionais de enfermagem de um hospital escola. Rev. Latino-Am. Enfermagem, Ribeirão Preto, v. 14, n. 4, p. 517-525. Ago. 2006.

[16] ENRIQUEZ, Eugene. 0 trabalho, essência do homem? 0 que é trabalho?. Cadernos de Psicologia Social do trabalho, v. 17, p. 163-176, São Paulo, 2014.

[17] FIORATTI, Jete Jane. Os direitos do homem e a condição humana no pensamento de Hannah Arendt. Revista de Informação Legislativa., Brasília a. 36 n. 142, p.53-63, abr./jun. 1999.

[18] FLACH, Leonardo et al. Sofrimento psíquico no trabalho contemporâneo: analisando uma revista de negócios. Psicologia e Sociedade, Florianópolis , v. 21, n. 2, p.193-202. 2009.

[19] FRANÇA, Ana Cristina Limongi; RODRIGUES, Avelino Luiz. Stress e trabalho; uma abordagem psicossomática. 4 ed. São Paulo: Atlas, 2009.

[20] FRANKL, Viktor E. Em busca de sentido: um psicólogo no campo de concentração. Tradução de Walter O. Schlupp e Carlos C. Aveline. Porto Alegre, Sinodal, 1987.

[21] FRANKL, Viktor E. Psicoterapia para todos. Tradução: Antônio Estevâo. Allgayer. 3. ed. Petrópolis: Vozes, 2018.

[22] GIANNINI, Susana Pimentel Pinto et al. Distúrbio de voz e estresse no trabalho docente: um estudo caso-controle. Cad. Saúde Pública, Rio de Janeiro, v. 28, n. 11, p. 2115-2124, nov, 2012. 
[23] GIL, Suelen Tavares. O trabalho e a pandemia: um futuro a partir da dignidade humana, do valor social do trabalho e do trabalho decente. Revista do Tribunal Regional do Trabalho da 10a Região, v. 24, n. 1 , p. $118-132,2020$.

[24] GLINA, Debota Miriam Raab; ROCHA, Lys Esther. Saúde Mental no trabalho: da teoria à pratica. Ramadam ZBA / Rev Bras Med Trab. v. 10, n.1, p.132-133. 2012.

[25] GODOY, Arilda Schmidt. Pesquisa qualitativa: tipos fundamentais. Revista de administração de empresas, 1995.

[26] GONÇALVES, Jonas Rodrigo. Como fazer um projeto de pesquisa de um artigo de revisão de literatura. Revista JRG de estudos acadêmicos - Ano ll, volume ll, n. 5, 2019.

[27] HELOANI, José Roberto; CAPITÃo, Cláudio Garcia. Saúde mental e psicologia do trabalho. São paulo em perspectiva, v. 17, n. 2, p.102-108, 2003.

[28] HONORATO, Cecília Mirelle Almeida; MACHADO, Flávia Christiane de Azevedo. Fatores desencadeantes do estresse laboral na emergência médica: uma revisão integrativa. Revista ciência plural, v. 5, n. 1, p. 52-70, 2019.

[29] KONRATH, Ângela Maria. O trabalho como condição humana: do moderno Prometeu ao animal laborans e o homo faber: o trabalho intensificado e as garantias do direito ao trabalho. Recurso eletrônico. Santa Cruz do Sul: Essere nel Mondo, 2014.

[30] KROEFF, Paulo. Logoterapia: uma visão da psicoterapia. Revista da Abordagem Gestáltica, v. 17, n. 1, p. 68-74, jan-jun, 2011.

[31] MELEK, Tangriane Hainiski Ramos. Condições de trabalho e saúde: um olhar para os trabalhadores de mineração. Tese de doutorado. Universidade tuiuti do paraná. Curitiba, 2017.

[32] MIGUEZ, Eloisa Marques. Educação em Viktor Frankl: entre o vazio existencial e o sentido da vida. São Paulo, 2015.

[33] MONTALI, Lilia. Relação família-trabalho: reestruturação produtiva e desemprego. São Paulo Perspec., São Paulo , v. 17 , n. 2, p. 123-125, 2003.

[34] NEVES, José Luis. Pesquisa qualitativa: características, usos e possibilidades. Caderno de pesquisas em administração, São Paulo, 1996.

[35] NORONHA, Ana Paula Porto; FERNANDES, Dario Cecilio. Estresse laboral: análise da produção científica brasileira na SciELO e BVS-Psi. Fractal, Rev. Psicol., Rio de Janeiro , v. 20, n. 2, p. 491-501, Dec. 2008.

[36] PEDROZO, Paulo Ricardo Vijande. A pessoa humana e a busca da máxima efetivade do valor social do trabalho nas relações laborais: limites à flexibilização trabalhista. Unicesumar - Centro Universitário Cesumar. 2016.

[37] PETERSON, Jordan B. 12 regras para a vida: um antídoto para o caos. Rio de Janeiro: Alta books. 2018.

[38] PINHEIRO, Letícia Ribeiro Solto; MONTEIRO, Janine Kieling. Refletindo sobre desemprego e agravos à saúde mental. Cadernos de Psicologia Social do Trabalho, v. 10, n. 2, p. 35-45. 2007.

[39] RIBEIRO, Carla Vaz dos Santos; LEDA, Denise Bessa. Sentidos atribuídos ao trabalho na sociedade contemporânea e as repercussões na subjetividade do trabalhador. Revista espaço acadêmico - n. 211. Dez, 2018.

[40] SALVADOR, Luiz; FILHO, Olimpio Paulo. Higidez física e mental - a efetividade das leis da infortunística como instrumento de dignificação do trabalhador: mens sana in corpore sano. In VIZZACCARO-AMARAL, André Luís; MOTA, Daniel Pestana; ALVES, Giovanni. Trabalho e saúde : a precarização do trabalho e a saúde do trabalhador no Século XXI. — São Paulo : LTr, 2011.

[41] SAMPAIO, Jader dos Reis; GALASSO, Leonilde M.R. Stress no mundo do trabalho: uma trajetória conceitual. In FRANÇA, Ana Cristina Limongi; RODRIGUES, Avelino Luiz. Stress e trabalho; uma abordagem psicossomática. 4 ed. São Paulo: Atlas, 2009.

[42] SCHIMIDT, Maria Luiza Gava. Saúde e doença no trabalho: uma perspectiva sociodramática. São Paulo: Casa do Psicólogo, 2010. 
[43] TORRES, Iraildes Caldas. A visibilidade do trabalho das mulheres ticunas da Amazônia. Rev. Estud. Fem., Florianópolis , v. 15, n. 2 , p. 469-475. Ago. 2007.

[44] TRINDADE, Jorge. Manual de Psicologia Jurídica para operadores do Direito / 6. ed. rev. atual, e ampi. - Porto Alegre: Livraria do Advogado Editora, 2012.

[45] VIEIRA, Isabela; RUSSO, Jane Araujo. Burnout e estresse: entre medicalização e psicologização. Physis: Revista de saúde coletiva, v. 29,n. 2, p. 1-22, 2019.

[46] WEIL, Pierre. Relações humanas na família e no trabalho. ilustrações de Roland Tompakow. - 53. ed. - Petrópolis, Rio de Janeiro: Vozes, 2005.

[47] ZANELLI, José Carlos. Estresse nas organizações de trabalho: compreensão e intervenção baseadas em evidências: Porto Alegre: Artmed, 2010.

[48] ZANELLI, José Carlos; BORGES-ANDRADE, Jairo Eduardo; BASTOS, Antonio Virgílio Bittencourt. Psicologia, organizações e trabalho no Brasil. 2. ed. Porto Alegre: Artmed, 2014.

[49] ZANELLI, José Carlos. O psicólogo nas organizações de trabalho. Porto Alegre: Artmed, 2002. 


\section{Capítulo 8}

O sofrimento e a superação a partir de um estudo de caso das experiências de Alexander Sozhenitsyn $e$ Viktor Frankl

\section{Matheus de Sá Moraes}

Resumo: 0 sofrimento psíquico é natural de todo ser humano; não se pode viver sem sofrer. Esse fenômeno é motivo de estudo para inúmeras fontes do saber: ciência, filosofia, teologia, mesmo o senso comum não está privado da discussão acerca do sofrimento. Tão verdadeiro quanto o fato citado acima é afirmar que há pessoas também que superam os sofrimentos, por mais difíceis que sejam. Um exemplo claro disso é a vida de Alexander Solzhenitsyn e Viktor Frankl. Para isso o trabalho teve por objetivo compreender o enfrentamento do sofrimento a partir das perspectivas de Alexander Solzhenitsyn e Viktor Frankl. Utilizou de uma pesquisa bibliográfica sistemática em livros, artigos científicos, trabalhos acadêmicos, além de pesquisas em sítios eletrônicos e registros audiovisuais. Quanto aos autores, Alexander Solzhenitsyn foi um literário russo que fora preso no campo de trabalho forçado do governo comunista da União Soviética (Gulag) e depois condenado ao exílio, e Viktor Frankl um psiquiatra que esteve preso nos campos de concentração nazista durante a Segunda Guerra Mundial. Ambos sofreram com o cerceamento de suas "liberdades", a fome, o trabalho sob condições inumanas, etc. No entanto, mostraram condutas resilientes em meio às piores situações, sempre vendo no sofrimento uma via de aprendizado, oportunidade e redenção.

Palavras-chave: Sofrimento; superação; Solzhenitsyn; Frankl. 


\section{INTRODUÇÃO}

A palavra "patologia" vem do grego em que pathos significa "paixão", "sofrimento" e logos "lógica", "conhecimento" (CECCARELLI, 2005), o prefixo "psico" advém do grego psyché, referente ao que é da "alma", das funções intelectuais e morais (MANO; COSTA, 2015). Portanto, psicopatologia seria um discurso a respeito do sofrimento psíquico.

O significado de psicopatologia (sofrimento psíquico) que o trabalho propõe não é, necessariamente, patológico no sentido de transtornos psiquiátricos, tal como Campbell (1986 Apud DALGALARRONDO, 2019, p. 26) define, sendo "o ramo da ciência que trata da natureza essencial da doença ou transtorno mental - suas causas, as mudanças estruturais e funcionais associadas a ela e suas formas de manifestação". No entanto, entende-se que os conceitos e práxis que serão discutidos possam servir para o contexto clínico e demais áreas da psicologia.

A respeito da superação do sofrimento, não é necessário um vasto estudo científico para conhecer histórias de pessoas que, apesar de todo o sofrimento, seja físico ou psíquico, conseguiram de algum modo dar continuidade às suas vidas e superá-los. "Existem testemunhos que atestam: comunidades e indivíduos que cresceram com experiências difíceis e superaram os obstáculos" (SILVEIRA; MAHFOUD, 2008, p. 568). Os autores escolhidos para o estudo de caso que o trabalho apresenta são provas disso. Viktor Frankl e Alexander Solzhenitsyn ficaram presos nos campos de concentração nazista e comunista, respectivamente, e superaram todas as adversidades que lhes foram proporcionadas. Frankl entendia o sofrimento como uma oportunidade de encontrar um sentido para a existência (BRANDÃO, 2011). Solzhenitsyn também enxergava o sofrer como uma oportunidade; para ele, era uma chance de um desenvolvimento espiritual (McKAY, 1971).

Com base nisso, este trabalho teve por objetivo geral compreender o enfrentamento do sofrimento a partir das perspectivas de Alexander Solzhenitsyn e Viktor Frankl. Para este fim, buscou-se responder os seguintes objetivos específicos: a) levantar fatores precipitantes que contribuam para o enfrentamento; b) entender como a resiliência se apresenta nos momentos de sofrimento; c) identificar como a história de vida particular contribui.

A discussão a ser apresentada tendo por base os objetivos supracitados são de grande importância para a atuação psicológica. 0 sofrimento tem conquistado a atenção e é reforçado pelo meio social de um modo que não se via outrora (SILVEIRA, 2007 Apud MOREIRA; HOLANDA, 2010). Desse modo, partindo da premissa de que a academia é o ambiente propício para a promoção do saber, o trabalho apresenta discussões das experiências vivencidas pelos autores, sempre embasando em conceitos científicos. Dessa forma, enriquecendo o conhecimento e permitindo melhorias na atuação do profissional de psicologia, além de produzir mais um trabalho acadêmico, o que contribuirá no levantamento de dados em pesquisas futuras. Finalmente, se este é um tema em que não só o meio acadêmico-científico toma para si, vide que tornou-se um assunto recorrente até mesmo no senso comum, os frutos desta pesquisa dar-se-ão também à sociedade, permitindo esclarecimentos acerca do tema, o que possibilitará o conhecimento do sofrimento e como cada um, com sua história particular e de outras formas, poderá ser motor para o enfrentamento de seu sofrimento psíquico.

\section{REFERENCIAL TEÓRICO}

\section{Considerações terminológicas}

Reconhece-se que há uma distinção entre dor e sofrimento;

quando falamos de sofrimento, estamos sempre nos referindo a um tipo de dor, ou seja: "sofrer quer dizer ter dor". Há uma distinção entre a dor física, que ocorre quando o corpo é lesionado no seu exterior ou no interior, e dor na alma, está ligada à uma dimensão emocional do ser humano (SANTOS; PEDROSA-PÁDUA, 2018, p. 21)

Lavelle (2014 Apud SANTOS; PEDROSA-PÁDUA, 2018) afirma que a primeira [dor física] refere-se à dor ligada ao corpo, com isso, ao instante; por sua vez, a segunda [dor moral], "que configura o sofrimento" é sempre ligada ao presente. "Assim, podemos dizer 'que a dor só diz respeito a um aparte de mim mesmo; já no sofrimento, o eu está envolvido por inteiro (LAVELLE, 2014, p. 67-68 Apud SANTOS; PEDROSAPÁDUA, 2018, p. 21). Frankl (1987), metaforiza quanto ao sofrimento comparando-o a um estado gasoso, em que por mais que seja "pequeno" ocupa todo o espaço vazio na alma. A metáfora de Frankl faz jus à afirmação de que no sofrimento moral não há uma extensão, por não haver localização, mas há intensidade (DOS SANTOS, 1956). 
No entanto, é importante salientar que só a partir do século XVI que a psicopatologia concentrou sobre si maior interesse; "até então não se conhece uma psiquiatria distinta da área médica" (ROSAS, 2010, p. 51). Com isso, é raro encontrar termos como "sofrimento psíquico" em civilizações que viveram antes do século XVI - até mesmo depois do século XVI tal termo ainda demorou a ser usado. Portanto, termos como "dor”, “doença”, “doença mental”, "sofrimento”, "melancolia”, "desânimo”, “angústia”, etc. serão comuns e designarão a mesma coisa;

Ademais, entende-se que mesmo que uma dor física esteja acomentendo alguém, esta será entendida, em última análise, como que influenciadora do sofrimento psíquico; ora, uma pessoa acometida por uma doença certamente mudará a forma "como se alimenta, se movimenta, interage consigo e com os outros (OLIVEIRA, 2016, p. 228). A nível alusivo, permita-se o exemplo que Veras (2007) faz ao citar a situação de pessoas com HIV, que além das condições orgânicas fragilizadas por conta do vírus, ainda se veem em situação de humilhação e preconceito por serem consideradas sujas, promíscuas e demais estigmas.

O que ocasiona a compreensão de que não há fatos psicológicos que não reflitam fisiologicamente, assim como não há fatos fisiológicos que não interfiram psicologicamente (DOS SANTOS, 1956).

\section{Considerações históricas}

É certo que o sofrimento como é visto hoje se difere, e muito, de como era visto outrora. Assim, considerase importante apresentar uma revisão histórica acerca do tema, pois "a percepção e o significado da dor enquanto experiência do ser humano também é modulada pela cultura” (GUSMAN, 1997, p. 15). Ademais, a compreensão dos processos históricos e culturais será extremamente útil para entender como a experiência do sofrimento, bem como as atitudes tomadas para que pudessem superar as adversidades, se apresentam no estudo de caso que será desenvolvido mais a frente.

\section{As sociedades gregas}

Ceccarelli (2005 Apud PESSOTTI, 1995) traz uma análise cronológica do sofrimento desde as sociedades gregas com a era pré-socrática em que o sofrimento era visto muitas vezes como castigo dos deuses, ou mesmo como forma de expiação dos crimes cometidos.

Anteriormente à concepção de Hipócrates sobre a 'doença mental', todo mal que afetava o homem: a perda da razão ou o adoecimento físico, era obra da punição ou vingança dos deuses. Aquele que se econtrava doente, enlouquecido, abatido, sem vida, pagava por um erro que ele mesmo havia cometido ou seus antepassados. Sobre uma base mitológica se constituía a explicação para o sofrimento na doença (SANTA CLARA, 2009, p. 3)

Para Hipócrates (460-377 a.C), ambas ideias estavam equivocadas (ROSAS, 2010). Para o pai da medicina, as doenças seriam desequilíbiros dos temperamentos - sanguíneo, melancólico, colérico e fleumático assim, deixando de ter causas sobrenaturais (SANTA CLARA, 2009). É interessante ressaltar que Aristóteles (384-322 a.C) não nega a proposição de Hipócrates; no entanto, afirma que o desequilíbrio dos fluidos humorais é necessário para o Homem. Os gênios, filósofos, poetas e artistas teriam a "melan" (negro) e "choles" (bíle) em excesso. Doença e normalidade passam a caminhar lado a lado (SANTA CLARA, 2009).

\section{A filosofia oriental}

Apesar da distância, não só geográfica, das civilizações orientais, é notável sua influência no Ocidente, sobretudo na filosofia de Nietzche, nas psicoterapias cognitivo-comportamentais de terceira onda - como é o caso do mindfulness ${ }^{1}$-, e também na fenomenologia existencial de Heidgger. Com isso, optou-se por explanar o Budismo, visto que ele certamente exerce mais influência.

\footnotetext{
1 “Mindfulness é uma tradução para o inglês da palavra 'sati' em pali. 0 pali era a língua da psicologia budista 2,5 mil anos atrás, e o mindulfuness é o ensinamento central dessa tradição (GERMER, 2015, p. 26).

0 mindfulness é a atenção plena; atenção focada na tarefa do momento (GERMER, 2015).
} 


\section{O budismo}

De modo geral, pode-se afirmar que no budismo viver, por si só, é sofrer. Esta é a primeira "nobre verdade"; dhukka, a vida difícil, imperfeita, dolorida (SEBOLD, 2013); "Eis, ó monges a nobre verdade sobre o sofrimento (a dor): o nascimento é sofrimento; a velhice é sofrimento; a doença é sofrimento; a morte é sofrimento [...]" (GIRA, 1992, p.51 Apud SEBOLD, 2013, p. 21).

No budismo, a principal causa do sofrimento é a crença de que o ser humano é um ser imutável (SEBOLD, 2013).

De forma geral, no modo oriental, os organismos vivos são compreendidos como possuindo vários, um deles físicos e, os demais - variando em número segundo cada cultura - conformando um todo indissociável não apenas em relação a si mesmo, mas também em relação ao ambiente e ao universo (GUSMAN, 1997, p. 15).

Deste modo, a ideia de um "eu permanente" é ilusória, pois, para o budismo nossa natureza é da impermanência (SEBOLD, 2013).

Nesta filosofia o sofrimento também possui suas origens - cinco agregados (cinco skandhas) - podendo ter origem na corporeidade, sentimentos e sensações, percepções, intenção e vontade, e consciência. Essas origens se relacionam com a segunda "nobre verdade"; "tanha"; a "sede insaciável". 0 apelo, desejo, busca, de forma exacerbada aos bens terrenos causaria malefícios ao homem (SEBOLD, 2013), tendo ele que se desprender de tais desejos. Neste ponto, a volição estaria estritamente ligada ao sofrimento.

\section{O cristianismo e a idade média}

"Quando viverei em perfeita liberdade, sem nenhum impedimento, sem aflição da alma e do corpo? (KEMPIS, 2015, p. 215)." Este é um excerto da "Imitação de Cristo" escrita pelo frei agostiniano Tomás de Kempis, e revela uma indagação do homem; "quando viverei sem aflição da alma e do corpo?"

Primeiro, cabe entender o contexto cultural da época. Na Idade Média todas as ações dos homens tinham um fim último, não as coisas terrenas, mas as "coisas do alto". "Tudo era 'por Deus' e 'para Deus': a música; a arte; a escultura; a luta; a catedral; a universidade... tudo (AQUINO, 2009, p. 82)". 0 homem não se separava de Deus pois era de seu conhecimento que isto lhe causaria desequilíbrio (AQUINO, 2009).

Outrossim, o sofrimento não era diferente. Não que fora mandado por Deus aos homens; mas os homens usufruindo de sua própria liberdade o trouxeram ao mundo; "apareceu o sofrimento, a doença e a morte porque o ser humano pecou" (KAMATI, 2014 Apud JOÃO PAULO II, 1984). Dessa forma, "o homem sofre por causa do mau, que é uma certa falta, limitação ou distorção do bem (KAMATI, 2014, p. 32)”.

Kamati (2014) continua e afirma que o homem sofre por não participar de um bem; sofre por não ter o que deseja - segundo a reta ordem.

É certo também que o ser humano não age passivamente com este sofrimento e nada pode fazer, ou que não sirva de algo. 0 sofrimento é visto como uma maneira de assemelhar-se a Cristo, é participar do sofrimento de Cristo, e que mediante a fé reveste-se de um novo significado (JOÃO PAULO II, 1984); assim, "com a paixão de Cristo todo sofrimento humano veio a encontrar-se numa nova situação (JOÃO PAULO II, 1984, p. 16)."

Bom é passarmos algumas vezes por aflições e contrariedades, porque frequentemente fazem o homem refletir, lembrando-lhe que vive no desterro e, portanto, não deve pôr sua esperança em coisa alguma do mundo (KEMPIS, 2015, p. 39).

Este extrato de Kempis recorda aos cristãos que no mundo terreno nenhuma felicidade é suficiente, que é vã a procura da plena felicidade nesta terra. Portanto, a alegria plena, sem qualquer sofrimento, só é possível em algo que seja pleno, não corruptível: "justo é que eu, mísero pecador, me sofra a mim com paciência, conforme quereis e suporte por minha salvação o fardo desta vida corruptível" (KEMPIS, 2015, p. 152). Desta forma, apenas a vida plena em Deus; a visão beatífica, aplacaria todo sofrimento. 


\section{A era moderna}

Certo é que cada tempo tem suas preocupações; a peste da Idade Média, as revoluções pós iluminismo, as guerras, o desemprego, a fome, etc. Dessa forma, todos estes eventos produzem consequências no homem; a mudança de vida, de pensamento, de anseios, angústias e sofrimentos:

As grandes revoluções representam papéis cruciais na odisséia humana. A Revolução Industrial ocorrida na Inglaterra integra o conjunto das Revoluções Burguesas do século XVIII, responsáveis pela crise do Antigo Regime, na passagem do capitalismo comercial para o industrial (OLIVEIRA, 2006, p. 22).

"A passagem da modernidade para a contemporaneidade ocasionou a mudança de um modelo de vida, resultado das transformações nas instituições fundantes da sociedade (OLIVEIRA, 2006, p. 86)." A sociedade moderna não crê mais que o sofrimento possa ser consequência do pecado original, de seus crimes, ou da condição deste plano, seus olhos se voltam para a imanência; resultado dos filósofos iluministas e positivistas, além da ascenção da sociologia, bem como das ideologias ${ }^{2}$; assim sendo, não só os anseios: a ascenção do proletariado, os direitos trabalhistas, a luta de classes, as guerras, etc., mas também as angústias e sofrimentos são englobadas na ordem social. Santos (2017) faz uma relação entre o sofrimento e a cultura de consumo: "a perspectiva do sofrimento psíquico aborda as tensões causadas pela individualidade na modernidade e enfatiza o consumo sob a ótica da disputa por status (p. 318)." Roudinesco (2000, p. 17 Apud OLIVEIRA, 2006), citando a depressão como grande mal do século, faz a seguinte afirmativa.

Forma atenuada da antiga melancolia, a depressão domina a subjetividade contemporânea, tal como a histeria do fim do século XIX imperava em Viena através de Anna 0., a famosa paciente de Joseph Breuer, ou em Paris com Augustine, a célebre louca de Charcot na Salpetrière. Às vésperas do terceiro milênio, a depressão tornou-se a epidemia psíquica das sociedades democráticas, ao mesmo tempo em que se multiplicam os tratamentos para oferecer a cada consumidor uma solução honrosa.

Oliveira (2006) argumenta que essa "sociedade democrática" citada pela autora, nada mais é do que a sociedade de controle. Corroborando com a ideia de Santos (2017) supracitada, a individualidade, advinda com essa "sociedade democrática", acabou por tornar o homem como único responsável por seus próprios êxitos e fracassos. Com isso,

Ehrenberg (2000) aponta que, se não conseguimos conduzir nossa charrete no caminho almejado e reconhecido (material, profissional, social, etc.), o sentimento de insuficiência torna-se implacável, trazendo apatia, desânimo e fadiga, esgotando o sujeito e tornando-o incapaz de agir. (OLIVEIRA, 2006, p. 71)

Também é possível traçar a relação entre o sofrimento e a fome, a guerra, a luta pela liberdade, pelos direitos. Pois como os olhares dos homens modernos voltam-se para a imanência, então a felicidade é presente, é imediata, não mais um futuro ou referente à escatologia. Essa imagem distorcida da felicidade acaba por gerar frustrações e alimentar a violência. Bauman (2003, p. 77 Apud SANTOS; PEDROSAPÁDUA, 2018, p. 24) afirma: "os obstáculos responsabilizados ou suspeitos de bloquear essa busca passaram a constituir o sistema de injustiça e uma causa legítima de rebelião". Ora, não é equívoco falar que o último século foi um dos mais sangrentos, com várias revoluções, guerras civis e duas grandes guerras mundiais.

\section{Biografia}

A priori, pode-se inferir que as vidas de ambos autores não têm nada em comum; eles não são do mesmo país, da mesma cultura, da mesma religião, nem sequer se conheceram. Entretanto, é possível enxergar semelhanças entre os autores. Solzhenitsyn foi um grande escritor e pensador russo que tinha a alma humana como um tema explícito em suas obras (MAHONEY, 2019). Para Townley (1998), Alexander é mais que um escritor, uma vítima do comunismo soviético; ele é uma proeminente figura de um século

\footnotetext{
2 "O cerne das ideologias é a imanentização do schaton, a redução dos fins a si mesma, o que normalmente desemboca em utopias. A felicidade do homem, ou qualquer outro fim, devem estar sempre englobados pelos ditames do sitema (MATIAS, 2018)."
} 
conturbado. Se tais palavras são aplicadas a Solzhenitsyn, não seria exagero aplicá-las também a Frankl. Fossati (2010, p. 91) afirma que

a história de vida de Frankl pode ser considerada um protótipo de uma história que articula as dimensões de uma vida pautada pela busca e a construção do sentido de existir com o desenvolvimento de um referencial teórico suscitado pelas reflexões no decorrer desta existência.

Essa parte do trabalho dedica-se a uma breve explanação a respeito da vida dos autores escolhidos para o estudo de caso. Pois, se mais a frente tratar-se-á de suas vivências de sofrimento e superação, faz-se necessário compreender previamente o contexto em que ambos os sujeitos estavam inseridos

\section{Alexander Solzhenitsyn}

\section{Figura 1}

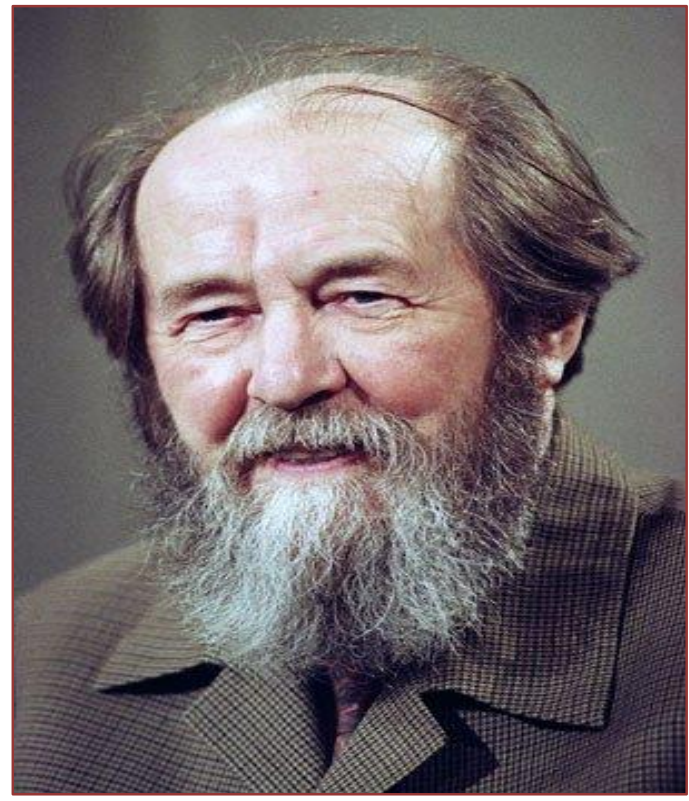

Fonte: Britannica ${ }^{3}$

Alexander Issaievih Solzhenitsyn nasceu no dia 11 de dezembro de 1918, em Kislodov, Rússia. Sua mãe era datilógrafa em Rostov do Don e seu pai foi um estudante do Departamento de Filologia da Universidade de Moscou, mas que não chegou a terminar o curso por conta da Primeira Guerra Mundial, onde atuou no fronte alemão e morreu no verão de 1918, seis meses após o nascimento de Alexander (NOBEL PRIZE, 2020).

Desde a infância apresentava inclinação para a leitura e a escrita e anos mais tarde chegou a tentar publicar, no entanto seus escritos não foram aceitos (SOLZHENITSYN, 20-).

Começou a cursar matemática e física na Universidade de Rostov, apesar de achar que não era sua vocação. No entanto, reconhece o valor do curso, pois se não fosse por ele não teria trabalhado no "sharashka" - laboratórios científicos em que os prisioneiros trabalhavam -, nem lecionado física e matemática no durante o exílio (SOLZHENITSYN, 20-).

Em 1940 casa-se com Natalya Reshetovskaya e em 1941 é graduado no curso de física e matemática pela Universidade de Rostov (SOLZHENITSYN, 20-).

Chegou a lutar na Segunda Guerra Mundial, tornando-se captão da artilharia, até ser capturado em 1945 pelo Governo Soviético. 0 Governo interceptou uma correspondência, de Solzhenitsyn para um amigo da escola, que continha comentários considerados desrespeitosos sobre Joseph Stalin, ditador da URSS, e

\footnotetext{
${ }^{3}$ www.britannica.com/biography/Aleksandr-Solzhenitsyn
} 
Solzhenitsyn foi condenado a oito anos de prisão no campo de trabalho soviético, além de três anos de exílio (BRITANNICA, 2020).

Figura 2 Solzhenitsyn (à extrema direita) e amigos da faculdade

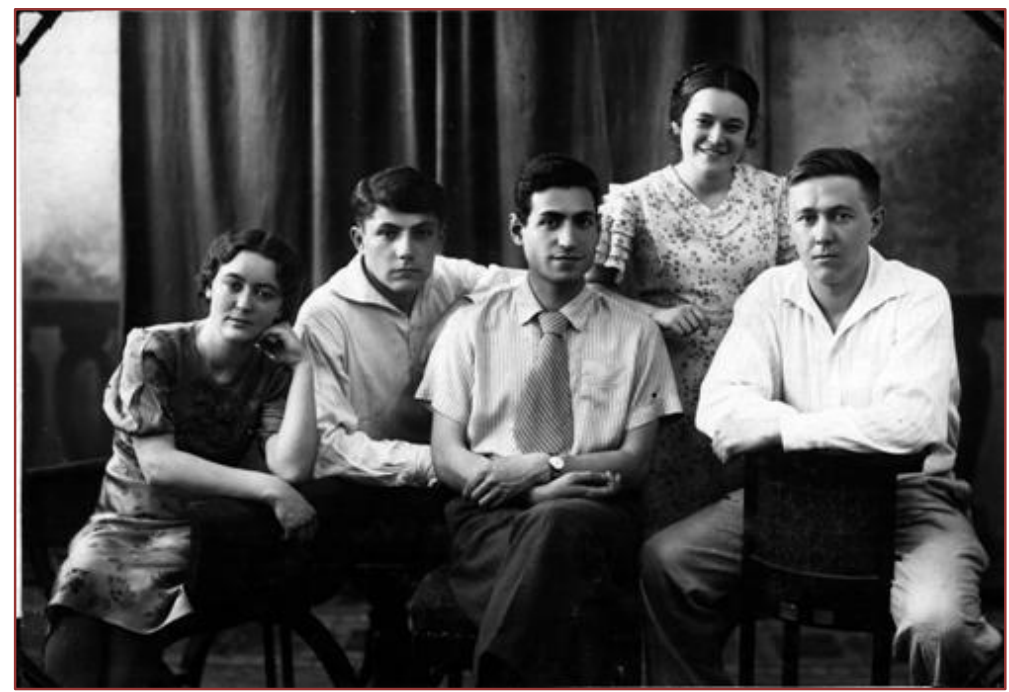

Fonte: Cultural and educational portal "Alexander Solzhenitsyn"4

Figura 3 Alexander Solzhenitsyn (sentado à extrema esquerda) durante a Segunda Grande Guerra

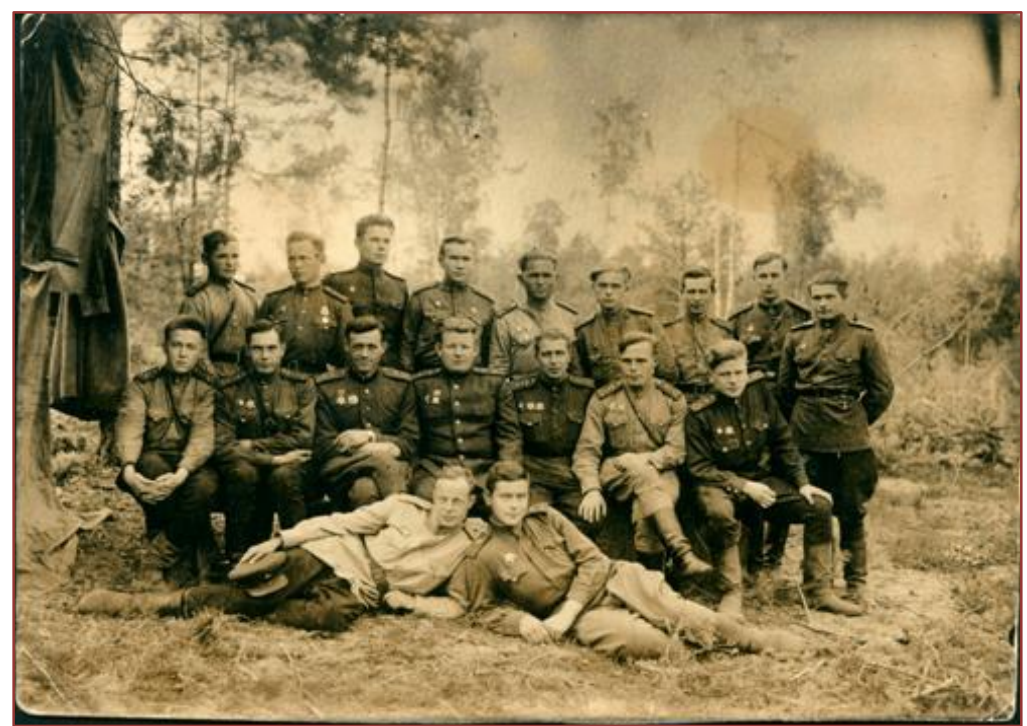

Fonte: Cultural and educational portal "Alexander Solzhenitsyn ${ }^{5}$

A seguir algumas datas importantes da vida de Alexander Solzhenitsyn (SOLZHENITSYN, 20-):

- 1953 - Foi exilado e mandado para a vila de Kok-Terek no Cazaquistão;

- 1956 - A pena ao exílio sob o artigo 58 foi absolvida;

- 1959 - Escreveu "Um dia na vida de Ivan Denisovich";

- 1965 - Iniciou os escritos de "Arquipélago Gulag”;

\footnotetext{
4 Disponível em: www.solzhenitsyn.ru/mediateka/photoalbums/detstvo_yunost_molodost/

5 Disponível em: www.solzhenitsyn.ru/mediateka/photoalbums/voyna/
} 
- 1966 - Completou o romance "Pavilhão de cancerosos";

- 1968 - Lançada a edição final de "O primeiro círculo";

- 1970 - Ganhou o Prêmio Nobel de Literatura;

- 1973 - No final de agosto o manuscrito "Arquipélago Gulag" foi apreendido pela KGB, e em dezembro o primeiro volume foi lançado em Paris;

- 1974 - Privado da cidadania soviética e expulso da URSS;

- 1989 - Início da publicação de "Arquipélago Gulag";

- 1994 - Volta para a terra natal;

- 2008 - No dia 3 de agosto, em Troitse-Lykovo, faleceu e está enterrado no cemitério do Mosteiro de Donskoy.

\section{Viktor Frankl}

Figura 4 Viktor Frankl

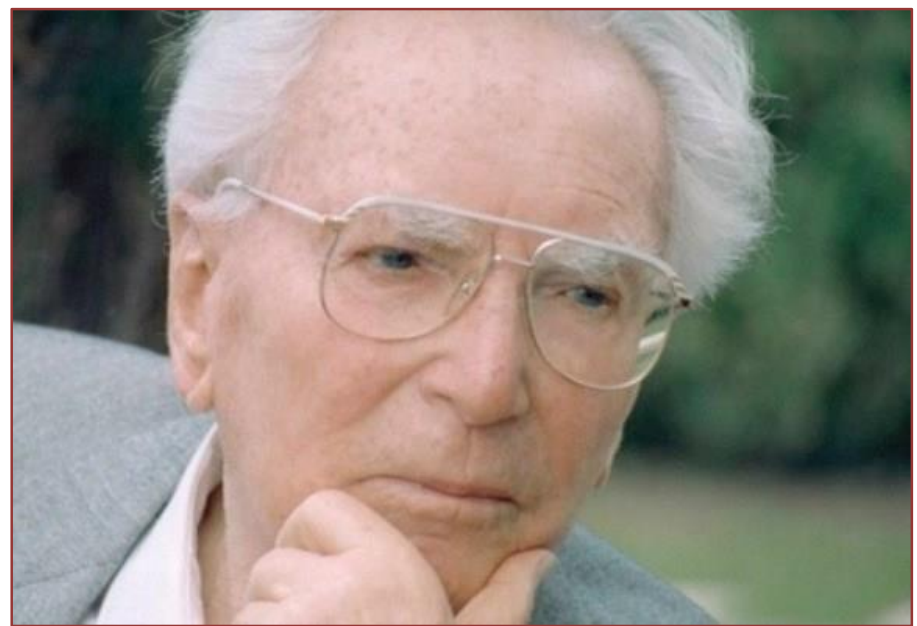

Fonte: Instituto Viktor Frankl ${ }^{6}$

Viktor Emil Frankl nasceu no dia 26 de março de 1905 em Viena, Áustria. Era o caçula dos três filhos do casal Gabriel e Elsa. Seu pai foi diretor do Ministério da Educação e teve grande destaque pelo seu trabalho em relação aos problemas da juventude. Sua mãe pertencia à família do rabino Leow (RODRIGUES; BARROS, 2009).

Foi o criador da Logoterapia, a terceira escola vienense de psicoterapia - escola onde o terapeuta auxilia o paciente a empenhar-se na procura do sentido de sua existência (RODRIGUES; BARROS, 2009).

Apesar da criação da Logoterapia só acontecer anos mais tarde. Desde criança Frankl já demonstrava interesse no assunto do sentido da vida. Aquino (2020) conta que quando Frankl tinha apenas 13 anos de idade, na escola, interrogou seu professor de ciências que afirmava que a vida não passava de um processo de oxidação e combustão. "Quando tinha apenas 15 ou 16 anos pronunciou uma conferência sobre o sentido da vida na Universidade Popular no Grupo de Trabalho liderado por Edgar Zilsel, filósofo pioneiro da sociologia da ciência" (AQUINO, 2020, p. 233).

Frankl inicia em 1924 o curso de medicina na Universidade de Viena e se forma em 1930. "Durante esse período, publicou vários artigos, especialmente e, em sua maioria, dedicados à juventude, fase na qual o autor percebia os sofrimentos, conflitos e a falta de sentido e significado na vida" (RODRIGUES; BARROS, 2009, p. 16). 
Figura 5 Frankl como médico do Hospital Neurológico em Viena

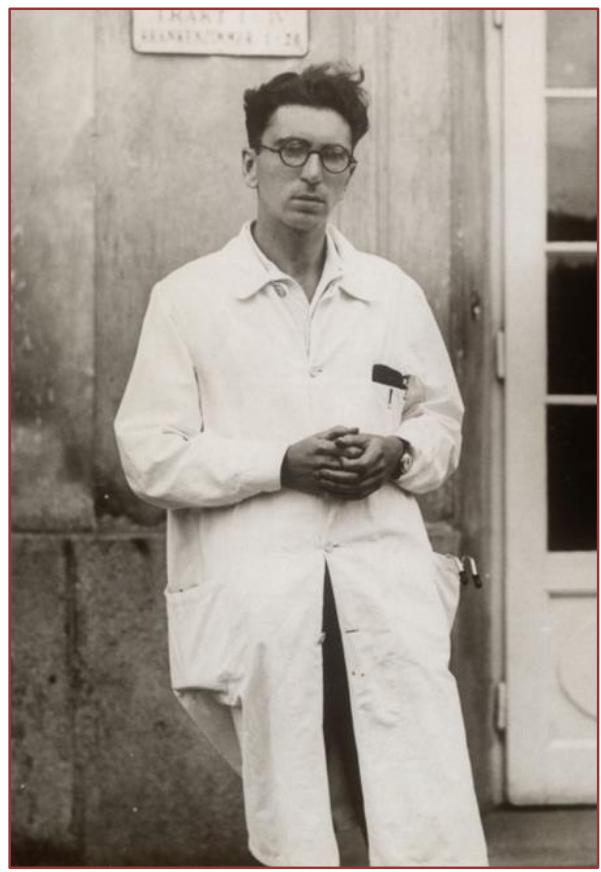

Fonte: Viktor Frankl Institut ${ }^{7}$

Durante esse tempo de faculdade, Frankl manteve contato com Freud e posteriormente com Adler. No entanto, após um tempo em que teve atração pela Psicologia Individual de Adler, Frankl começa a desvincular-se desta teoria e passa a elaborar sua própria teoria, o que seria mais tarde conhecida como Logoterapia.

Em 1938 Hitler invade a Áustria e em 1942 Frankl é capturado pelos nazistas. Ali, no campo de concentração, Frankl começa a pôr em prática os conceitos que anos mais tarde seriam tão aprofundados pela Logoterapia.

\section{A vivência de sofrimento nos campos de concentração e de trabalho forçado}

0 não iniciado que olha de fora, sem nunca ter estado num campo de concentração, geralmente tem uma ideia errada da situação num campo destes. [...] não tem a menor ideia da feroz luta pela existência [...] (FRANKL, 1987, p. 9).

Por tais palavras pode-se conjeturar as maiores dificuldades que foram vivenciadas pelos prisioneiros, e que não eram exclusivas do campo nazista. Nos campos soviéticos, Scamell (2008) afirma que Solzhenitsyn, nos primeiros meses, quase morreu pela fome e pela sobrecarga de trabalho. Por sinal, essa era a vida nos gulags: "trabalho, trabalho, trabalho; fome, frio [...]" (SOLZHENITSYN, 1975 p. 198). Cada dia uma luta pela existência. Solzhenitsyn enfrentou transportes desumanos, leis severas que regulavam a comida e o trabalho (ALEXOPOULOS, 2015).

A iminência da morte era algo totalmente presente nessas condições. Ademais, apesar de no campo soviético a intenção não ter sido de extermínio, tal como no campo nazista, era extraído o máximo de energia possível dos prisioneiros (ALEXOPOULOS, 2015), o que muitas vezes acabava por levar a morte. Ademais, havia também as mortes resultantes de falta de saneamento, violência por parte dos guardas e dos outros prisioneiros (ALEXOPOULOS, 2015).

No campo nazista,

o apito estridente da locomotiva causa arrepios [...]. De repente, do amontoado de gente esperando ansiosamente no vagão, surge um grito: 'Olha a tabulta: Auschiwitz!' Naquele momento nao houve coração que não se abalasse. Todos

\footnotetext{
${ }^{7}$ Disponível em: www.viktorfrankl.org//biography.html
} 
sabiam o que significava Auschiwitz. Esse nome suscitava imagens confusas, nas horripilantes câmaras de gás, fornos crematórios e execuções em massa (FRANKL, 1987, p. 13);

Também havia a violência, a comida regrada e insuficiente, pois como Frankl (1987, p. 26) afirma: "alimentação diária consistia numa sopa bastante aguada distribuída uma vez durante o dia, e na minúscula ração de pão".

Quem não passou por isto ainda, dificilmente poderá imaginar o desgaste interior causado pelos conflitos íntimos que se desenrolam na pessoa do faminto. Não é fácil imaginar o que significa estar no valo, empunhando a picareta, e ficar sempre atento, à espera da sirene indicar nove e meia ou dez horas, ou da pausa de meia hora, ao meio-dia, com a distribuição da "merenda perguntando repetidamente as horas ao capataz, ou mesmo a passantes civis, caso não fossem pessoas intratáveis. Apalpávamos carinhosamente um pequeno pedaço de pão no bolso da capa, com os dedos desprovidos de luvas e entorpecidos de frio, quebrávamos um pedacinho que levávamos à boca para então, num último esforço da vontade, fazê-lo voltar ao bolso. É que nesta manhã havíamos jurado agüentar até ao meio-dia (FRANKL, 1987, p. 27).

Há conflitos internos entre os prisioneiros, as condições externas muitas vezes levavam a isso. Diate da situação desesperadora, ao perigo de morte, não havia quem não tivesse pensado em suicídio, mesmo que por um instante (FRANKL, 1987, p. 18-19). Solzhenitsyn, e os prisioneiros do campo soviético, não estava privados desse pensamento. Embora o escritor nunca tivesse considerado a hipótese, este chegou a ser tomado por pensamentos sombrios, em que para ele toda sua vida havia perecido (SOLZHENITSYN, 1975).

Figura 6 Prisioneiros nos Gulags

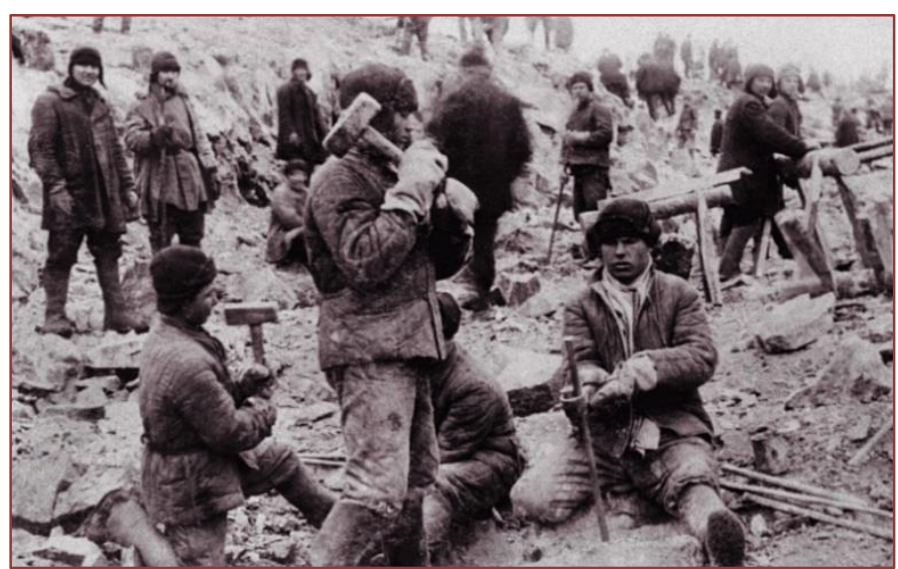

Fonte: The Telegraph ${ }^{8}$

As experiências de ambos autores, apesar da distância geográfica dos gulags para os campos de concentração, são próximas. Os dois ex-prisioneiros vivenciaram situações semelhantes, como a fome, o trabalho forçado sob condições desumanas, a humilhação. No entanto, apesar de todas as condições adversas, ambos demonstraram uma atitude de superação, como será visto mais adiante.

8 Disponível em: www.telegraph.co.uk/news/2018/09/11/soviet-labour-camps-compassionate-educationalinstitutions-say/amp/ 
Figura 7 Prisioneiros de Auschiwitz

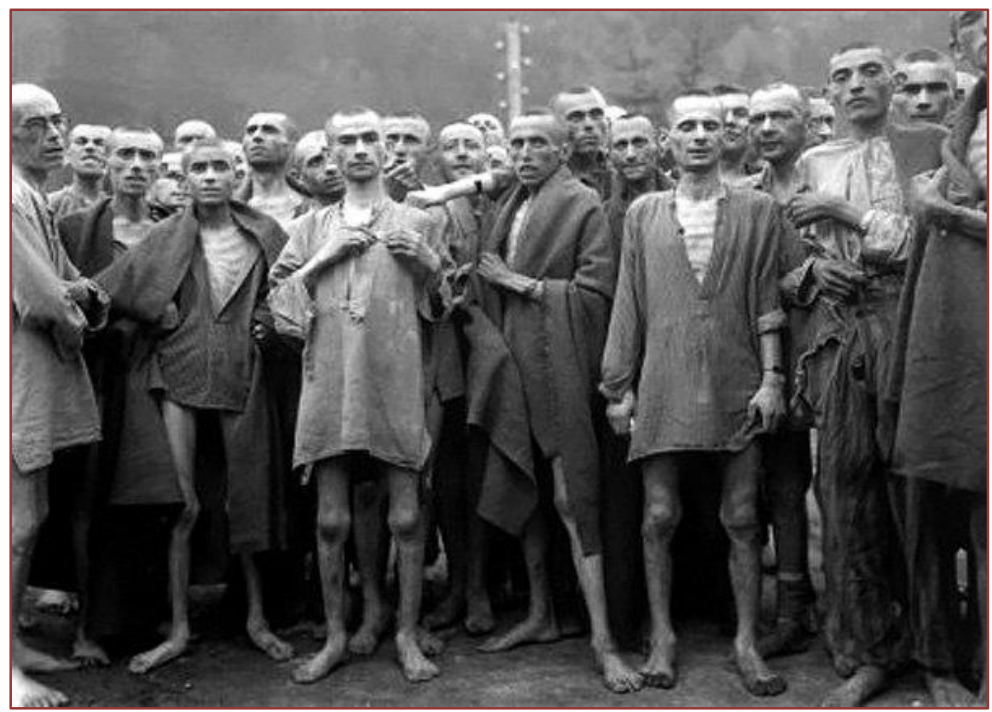

Fonte: Obvious ${ }^{9}$

\section{0 homem que ousa sofrer}

Com o que fora dito no capítulo anterior, mostra-se que o sofrimento faz parte da humanidade, ao passo que tentar extirpá-lo seria impossível. Há séculos as sociedades vêm buscando formas de "domínio da contingência"; maneiras de acabar com a dor, e acaba por ser algo inútil, pois o sofrimento sempre volta revestido de outros aspectos (MELICH, 2008). Mostra-se que "os atores humanos tecem complexos arranjos socioculturais e práticos seja para ocultar as aparições dessa caveira [a morte], seja para aplacar o impacto existencial dos momentos em que ela se mostra (PETERS, 2014, p. 103)." No entanto, a modernidade e pós-modernidade tentaram fazer isso e falharam de forma grotesca.

Frankl critica os últimos três séculos em que o homem buscou idolatrar a figura do Homo faber: o homem criador, com a tentativa de conter e negar o sofrimento

se enganaram e enganaram aos outros tentando acreditar que com o auxílio da actio [ação] e da ratio [razão] conseguiriam acabar com a dor, a miséria e a morte. A actio impediu que viesse a passio; esqueceu-se de que a vida é paixão. A ratio, a razão, a ciência, supostamente o conseguiriam. Não foi, pois, sem motivo que se procurou glorificá-las e fazer apoteose do homem racional, do Homo sapiens, ao qual caberia ensinar como se esquivar da realidade, da necessidade do sofrimento e da possibilidade de lhe dar um sentido (FRANKL, 1978, p. 243 Apud PEREIRA, 2017, p. 87).

Llompart (2012) adota a mesma posição de Frankl; para ele, a novidade do século passado é justamente a tentativa de extirpar as doenças, o sofrimento, qualquer vulnerabilidade, e até mesmo a morte, por meio da técnica.

Paradoxalmente, essa sociedade que deseja incansavelmente o bem-estar e conta com esse Homo sapiens e a ciência para tal realização, encontra-se totalmente "adoecida", não conseguindo frear o crescente número de pessoas com depressão e ansiedade (LIPOVETSKY; SERROY, 2011 Apud PEREIRA, 2017). Ao bem-estar, Solzhenitsyn (2015) o rechaça totalmente, bem como qualquer ponto de vista utilitarista, ao afirmar que ele [o bem-estar] e a privação do sofrimento acabam por deixar a ala subdesenvolvida.

Em oposição à essa espécie que não ousa sofrer, mas conhecer e criar, Frankl propõe o Homo patiens: o homem que sofre, que ousa sofrer. "O lema do Homo sapiens - 'sapere aude!' - ter-nos-ia levado a absolutizar a razão, transformando-a 'literamente em deusa' (FRANKL, 2014, p. 142 Apud PEREIRA, 2017, p. 87). Em contraposição ao lema do Homo sapiens há o lema: pati aude, ousa sofrer (FRANKL, 2014, p. 142 apud PEREIRA, 2017). Este lema preconizado por Frankl é totalmete corroborado por Solzhenitsyn (2015)

${ }^{9}$ Disponível em: obviousmag.org/archives/2011/05/viktor_frankl_um_psicologo_no_campo_de_concentraçao.html. 
quando este afirma que "é preciso ter coragem para aceitá-lo [o sofrimento] e entender que ele é enviado por algum motivo".

O Homo patiens é aquele que sabe sofrer, que se volta para o sentido, ainda que em meio a fracassos e sucessos (PEREIRA, 2017). Pois este Homo não se move horizontalmente entre o eixo fracasso-sucesso, mas de forma perpendicular entre os polos realização-desespero (FRANKL, 2005 Apud PEREIRA, 2017). (Figura 1).

Figura 1

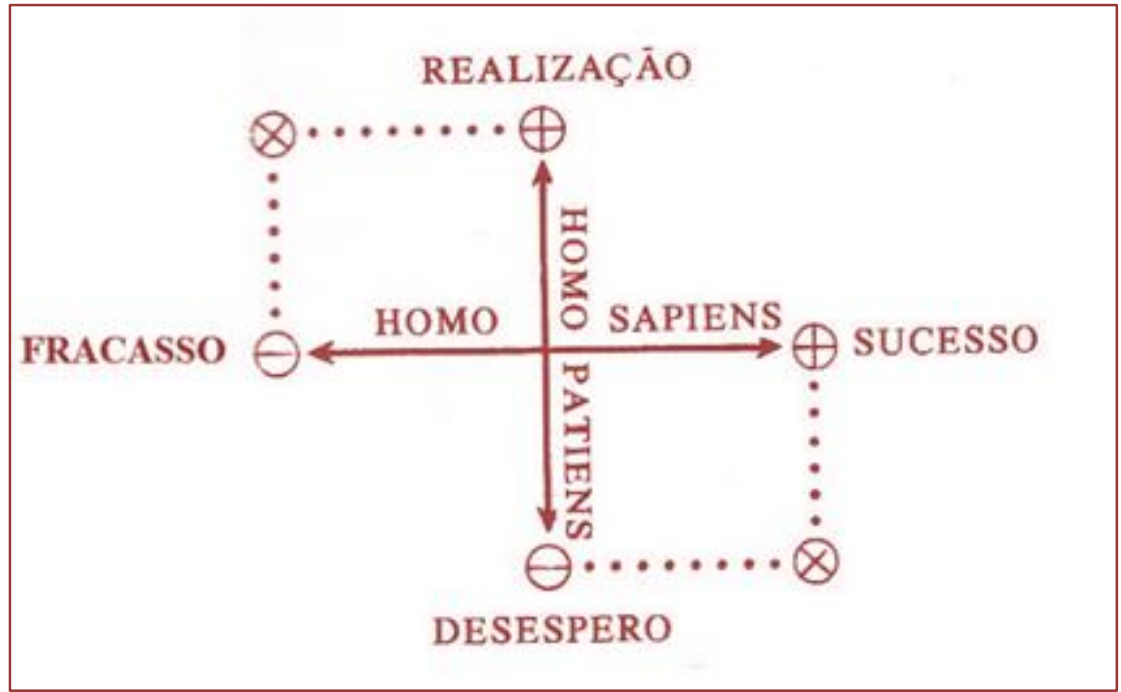

Adaptado de FRANKL, 2005, p. 35 Apud PEREIRA, 2017, p. 84

0 que se vê nessa negação de homem que sofre é uma tentativa de tirar algo que lhe é inerente; algo que não o incapacita, mas é uma possibilidade de superar-se. Pois, "o ser feliz não é aquele que não experimenta a dor ou que não participa da mesma, mas sim aquele que, apesar da dor, na dor e pela dor, constrói seu estado" (NOVELLI, 2012, p. 206).

\section{PROCEDIMENTOS METODOLÓGICOS}

O trabalho utilizou de uma pesquisa bibliográfica e qualitativa, que permitiu "uma mistura de procedimentos de cunho racional e intuitivo capazes de contribuir para a melhor compreensão dos fenômenos (NEVES, 1996)", consequentemente descritiva, já que procura a descrição dos fenômenos estudados (GIL, 2002).

Para isso foi utilizada a pesquisa bibliográfica sistematica, tendo como base o estudo de cao, em livros, artigos e plataformas digitais, como Scielo, Bvs, BvsPsi, para a coleta de dados, por se tratar de "um tipo de investigação focada em questão bem definida, que visa identificar, selecionar, avaliar e sintetizar as evidências relevantes disponíveis (GALVÃO; PEREIRA, 2014). Os sítios eletrônicos de revistas científicas digitais foram usados, principalmente para a descrição dos conceitos abordados. Para o levantamento de dados das biografias dos autores escolhidos, a maioria das informações foram retiradas de sites dedicados à memoria de Alexander Solzhenitsyn e Viktor Frankl, mas também recorreu-se aos livros e artigos. Desses materiais, 22 foram artigos, 11 livros, 10 trabalhos acadêmicos, 9 foram coletados em sites e 1 documento audiovisual.

Ao primeiro, é mister salientar, que precisou-se de uma mudança de paradigma para a realização da pesquisa devido a linguagem que o autor utiliza. Em seu mais famoso livro, "Arquipélago Gulag: Um experimento de investigação literária" - em tradução literal - que serviu como fonte primária para a descrição da vivência do autor, precisou-se entender o que o autor quer dizer com "investigação literária". Embora nenhum ocidental ouse atribuir valor de verdade à literatura, os eventos históricos não contradizem os documentos e o grande número de arquivos que foram utilizados por Solzhenitsyn (MORSON, 2019). 
Os descritores utilizados foram "sofrimento", "sofrimento psíquico", "superação", "resiliência". A revisão literária levantou trabalhos em sua maioria, em português, 34, seguido por muitos trabalhos em língua inglesa, 15, além dessas, 1 artigo em espanhol e 1 em russo.

Como qualquer outro trabalho, este também procurou respeitar a ética, por isso ao se utilizar de referências e citações, sempre deu-se crédito ao autor.

Para a inclusão do material, foram aceitos trabalhos publicados, em média, há 15 anos, para que assim os conceitos trabalhados e discutidos pudessem ser atuais e não obsoletos. No entanto, alguns poucos trabalhos que estavam fora desse parâmetro, tiveram espaço pela necessidade de informações a respeito dos autores que serviram como estudo de caso.

\section{RESULTADOS E DISCUSSÃO}

\section{Fatores precipitantes para o enfrentamento}

Ao analisar as experiências de sofrimento de Viktor Frankl e Alexander Solzhenitsyn, pode-se chegar a conclusão de que a primeira atitude que possibilitou o enfrentamento foi a de auto-reflexão. A partir dessa reflexão interior, ambos viram que o ser humano é um ser limitado, um ser que "acha-se alojado num corpo...que...é um invólucro de carne [...] [que] sente dor, sangra e um dia irá definhar e morrer (BECKER, 2010, p. 48 Apud PETERS, 2014, p. 102). Não apenas em matéria biológica, mas "suas faculdades de conhecimento reflexivo e conceitual” (PETERS, 2014, p. 102) acabam por torná-lo frágil e vulnerável frente, até mesmo a possibilidade do sofrimento (MELICH, 2008).

O que se pode ver nas experiências dos autores é que não há um momento em que se faça uma crítica ao sofrimento, em que se queira extirpá-lo, pois ambos reconhecem que isso acabaria por gerar mais sofrimento. Ambos tomam a dor como algo que não necessariamente traz sofrimento, mas que carrega consigo uma conquista e uma experiência de apredizado (FRANKL, 1987; PARNEL, 1980).

Desse modo, a única possibilidade é a de posicionar-se frente a situação adversa. Esta atitude implica outro ponto que possibilta o enfrentamento. A este homem que se reconhece como ser limitado e passível de sofrimento, cabe também afirmar que ele é livre. Ainda que Skinner (1998/1953 Apud CAVALCANTI, 2014) afirme que tratando-se de sobrevivência deve-se abandonar alguns princípios, dentre eles a liberdade, as atitudes tomadas por Frankl e Solzhenitsyn foram de sujeitos que, apesar das circunstâncias, ousaram se posicionar; de sujeitos livres. Frankl (1987) afirma que no campo de concentração, quando tudo fora tirado dos prisioneiros, a única coisa que restava era "última liberdade humana", assim, cabendo ao homem escolher a atitude em meio às mais adversas circunstâncias.

Em Solzhenitsyn também é possível enxergar a liberdade quando o autor diz que a "alma humana nunca é simplesmente reduzida às circunstâncias externas, mesmo as piores" (MAHONEY, 201910). Ademais, Solzhenitsyn (1975) afirma que no campo de trabalho há uma bifurcação, onde o sujeito deve fazer uma escolha: ou perder a consciência ou perder a vida. A primeira é a via onde o sujeito "perde-se" e não toma uma atitude resiliente frente a condição, procura "sobreviver a qualquer preço" como afirmava o literário russo; a outra via é onde o indivíduo aceita sua condição, de modo que ela não o determine, aceitando-a com coragem, pois sempre "há a possibilidade de todo ser humano assumir uma atitude diante dos condicionamentos" (SILVEIRA; MAHFOUD, 2008, p. 570).

\section{"Sobreviver a qualquer preço"}

Alexander Solzhenitsyn rechaça a ideia de "sobreviver a qualquer preço", para ele, isto sempre significa "o preço de outro" (SOLZHENITSYN, 1975, p. 603). Por isso o autor afirma que tomando essa escolha - de não sobreviver a qualquer custo - perde-se a vida. Ora, em um campo de concentração não se é estimado que alguém viva por muito tempo.

É interessante traçar um paralelo entre a posição assumida pelo escritor e sua oposição. Freud (1930/2010, p. 21) afirma que "é simplesmente o princípio do prazer que estabelece a finalidade da vida", no entanto, quando Solzhenitsyn descarta totalmente a ideia de sobreviver a qualquer preço, isto implica que esse princípio e a auto-preservação, proveniente dele, não determinam as atitudes do ser humano e tampouco podem ser o fim na vida humana. O vencedor do Prêmio Nobel, citando o exemplo seu compatriota Varlam Shalamov - que também esteve preso nos campos de trabalho forçado - que afirmava

10 The human soul is never simply reducible to external circumstances even of the worst kind. 
que os campos revelam a verdadeira humanidade, e que por isso o homem colocava a auto-preservação acima do amor (CUASAY, 2018), discorda dessa posição por afirmar com veemência que nem mesmo os campos podem causar uma corrupção moral (MAHONEY, 2019).

A posição adotada por Freud caminha junto com a filosofia utilitarista. Sendo esta última uma teoria criada nos séculos XVIII e XIX que afirma que a "coisa certa e justa a fazer é maximizar o prazer sobre a dor, pois nós, seres humanos, não suportamos o sofrimento (BERNARDINO; LIMA; PALMIERI, 2020, p. 159). No entanto, Alexander Solzhenitsyn vai na contramão desta teoria. Nele o sofrimento é aceitável e visto como um caminho de crescimento espiritual (CUASAY, 2018).

\section{"Sim à vida apesar de tudo"}

"Esse período de sua vida [campo de concentração], Frankl enfrentou com sabedoria e adotou uma postura de um otimismo trágico dizendo 'sim à vida apesar de tudo'" (AQUINO, 2020, p. 233). É mister destacar que "apesar de tudo" contrapõe-se à proposição "à qualquer custo". Na primeira, Frankl reitera sua posição de não desistência, ainda que isso lhe cause enorme sofrimento; tomando uma atitude resiliente; enquanto na segunda, a atitude a ser tomada seria de rejeitar qualquer dor, sofrimento ou desprazer que pudesse pôr em xeque sua existência.

Essa atitude também se opõe severamente a qualquer visão utilitarista, bem como a asserção cunhada por Freud de que o fim da vida é o princípio do prazer.

\section{O problema do suicídio}

Para entender como as visões de ambos ex-prisioneiros - de homens passíveis de dor, mas livres para se posicionarem frente a ele - os ajudaram a lidar com todo o sofrimento ao qual estavam submetidos, de modo que não tentassem eliminá-lo, mas que pudessem atingir uma posição resiliente perante eles, parece oportuno pontuar acerca da problemática do suicídio.

Não seria absurdo pensar que os prisioneiros dos campos de concentração cogitaram a ideia do suicidio, ainda que por um momento; ou que chegaram a cometer, mesmo que um número não tao elevado (FRANKL, 1987; SOLZHENITSYN, 1975). No entanto, Viktor Frankl e Alexander Solzhenitsyn nunca tomaram essa ideia como opção; Frankl (1987) fez uma promessa a si mesmo de não cometer suicidio, o que poderia significar que havia algo vivo e forte dentro de cada um (SOLZHENITSYN, 1975). Se ambos tivessem em mente que os seres humanos buscam a felicidade, querem se tornar e permanecer felizes. Essa busca tem dois lados, uma meta positiva e uma negativa; quer a ausência de dor e desprazer e, por outro lado, a vivência de fortes prazeres (FREUD, 1930/2010, p. 20-21), assim, procurando "agir sempre de forma a produzir a maior quantidade de bem-estar (princípio do bem-estar máximo)" (NEVES, 2010, p. 348), certamente aceitariam a asserção de que o princípio do prazer é a finalidade da vida humana (FREUD, 1930/2010). No entanto, Solzhenitsyn (2015) afirma que o completo bem-estar é a ruína da alma.

A partir da aceitação dessa concepção seria lícito que Viktor Frankl e Alexander Solzhenitsyn tirassem suas próprias vidas? Ora, não estariam eles exercendo o princípio do bem-estar máximo rechaçando qualquer desprazer? Estes são problemas morais que o trabalho não se propõe a tratar, no entanto, tornase visível que as posições de ambos autores contrapõe este ponto de vista. 0 que se vê é que Frankl e Solzhenitsyn assumem posições semelhantes de aceitarem com coragem suas condições, e reconhecem que "humano é, também, o 'ser que decide' (FRANKL, 1948/1993, p. 26 Apud SILVEIRA; MAHFOUD, 2008, p. 570), e este foi o primeiro passo para tomarem para si uma atitude de resiliência diante daquelas terríveis condições.

\section{As atitudes de resiliência de Alexander Solzhenitsyn e Viktor Frankl}

Como bem se sabe, a resiliência é a "capacidade elástica de um material para recobrar sua forma original depois de ter sido submetido a uma pressão deformadora" (ROCCA, 2007, p. 10). Assim sendo, no campo psicológico, pode-se dizer que a resiliência é a "capacidade humana universal de lidar e de superá-la [a adversidade], aprender ou mesmo ser transformado com a adversidade inevitável da vida" (ROCCA, 2007, p. 10). 
Frente uma limitação clara de possibilidades existenciais; diante de uma restrição muitas vezes impiedosa das condições para realizar valores de criação e vivência; perante uma situação adversa imodificável - física ou psicológica, social, econômica ou política -; ainda assim, o ser humano se vê perante o desafio da mais autêntica transcendência: encontrar sentido por meio de um modo digno de sofrer (MIGUEZ, 2015, p. 138).

Há na resiliência uma relação própria com os valores de atitude preconizados por Frankl (MIGUEZ, 2015). Entretanto, entende-se que "no momento em que o homem realiza um ato livre - fruto da intuição ou de análise, de discernimento ou deliberação - há concomitantemente a realização de um valor" (MIGUEZ, 2015, p. 128), percebe-se que a resiliência, apesar de estar mais atrelada aos valores atitudinais, não lhe é exclusiva. Pois os valores de vivência também podem ser atitiudes de resiliência.

Assim sendo, toma-se primeiro o valor de vivência para a explicação das aitudes que permitiram a superação do sofrimento, e posteriormente os valores atitudinais.

\section{Uma via de contemplação}

Frankl (1987) afirmara que no campo surgia uma profunda saudade de seus familiares, e que diante desta situação, só-lhe restava uma sensação: a de se consumir. Destaca-se nesse ponto a contemplação de Frankl à sua esposa, ou melhor, à imagem de sua esposa, já que os dois estavam em campos separados.

Enquanto avançamos aos tropeços, quilômetros a fio, vadeando pela neve ou resvalando no gelo, constantemente nos apoiamos um no outro, erguendo-nos e arrastando-nos mutuamente. Nenhum de nós pronuncia uma palavra mais, mas sabemos neste momento que cada um ainda só pensa em sua mulher. [...] agora meu espírito está tomado daquela figura à qual ele se agarra com uma fantasia incrivelmente viva, que eu jamais conhecera antes na vida normal. Converso com minha esposa. Ouço-a responder, vejo-a sorrindo, vejo seu olhar como que a exigir e a animar ao mesmo tempo e - tanto faz se é real ou não a sua presença - seu olhar agora brilha com mais intensidade que o sol que está nascendo (FRANKL, 1987, p. 31)

Essa via de contemplação se dá pelos valores de vivência: quando alguém toma algo do mundo, fazendo uma vivência da bondade, verdade, e, principalmente, das relações interpessoais (MIGUEZ, 2015). E segundo Miguez (2015, p. 128) "o fato de poder acessar valores que se referem a siuações típicas e repetitivas da existência alivia o homem”.

\section{O humor}

Outra atitude que se pode descrever como atitude resiliente é o humor. Mesmo nos campos de concentração, este não estava ausente. O senso de humor é considerado como um dos pilares da resiliência; trata-se de encontrar algo absurdo, engraçado, mesmo na tragicidade (ROCCA, 2007). Esse senso de humor permitiu que Solzhenitsyn, privado de toda liberdade - externa, ao menos - pudesse exclamar que: na prisão "ninguém pode privá-lo de sua família e de sua propriedade - pois você já foi privado delas" (SOLZHENITSYN, 1975, p. 607). Frankl (1987) tem arraigado em si um otimismo que sempre lhe acomete "nas piores situações", e com essa atitude chegou a pactuar com um amigo que ambos deveriam contar ao outro, pelo menos, uma piada por dia (FRANKL, 1987).

Desse modo, entende-se que o humor

constitui uma arma da alma na luta pela auto-preservação. Afinal é sabido que dificilmente haverá algo na existência humana tão apto como o humor para criar distância e permitir que a pessoa passe por cima da situação, mesmo que somente por alguns segundos (FRANKL, 2018, p. 35).

A proposição acima é corroborada por Silveira e Mahfoud (2008) ao afirmarem que, pelo humor, quando o sujeito ri de si mesmo ou de uma situação adversa, é criada uma distância entre seu eu e o problema.

Esse otimismo também pode ser visto no escritor russo. "Ele nunca perdeu seu senso de esperança, sua percepção de mundo como bom originariamente” (TOWNLEY, 1998, p. 79), mesmo quando tudo parecia perdido. 


\section{O papel da espiritualidade}

É notório nos escritos biográficos a respeito de Alexander Solzhenitsyn, e seus próprios escritos, o papel que a espiritualidade desenvolve. Não é possível entender as experiências do escritor russo sem sua espiritualidade.

Alexander entra na prisão como um descrente e sai de lá um cristão ortodoxo. No final do capítulo "The Ascent" de Arquipélago Gulag, ele narra um poema que escrevera durante seu tempo de prisioneiro, com destaque para as últimas palavras: "Deus do Universo! Eu creio novamente! Embora eu tenha Vos renunciado, Vós estivestes comigo!"11 (SOLZHENITSYN, 1975, p. 615). A confissão de Alexander permite que se faça uma relação com suas atitudes; para ele, a "fé é o fundamento e suporte da vida" (SOLZHENITSYN, 2007), desse modo entende-se a espiritualidade permite o enfrentamento das adversidades (FLECK et al., 2003 Apud CALVETTI; MULLER; NUNES, 2007). Pois de acordo com Shantall (1996) a dimensão espiritual da natureza humana emerge no sofrimento; além disso - continua Shantall há maior profundidade no entendimento das coisas, o sofrimento acaba por mudar a vida do ser humano.

Frankl vê a religiosidade como inerente ao ser humano e como uma necessidade da psyché de ir ao encontro do Outro e encontrar sentido (BRENCIO, 2015). Esse posicionamento de Frankl é contrário ao de Sartre que acredita que ao ser humano cabe encontrar coragem para encarar a falta de sentido de sua vida (BRENCIO, 2015); o que parece coadunar-se - de modo um pouco diferente - com a ideia de Heidegger de que "o engajamento nas condutas sociais cotidianas encobre a consciência da própria morte" (PETERS, 2014). Rocca (2007) caminha ao lado de Frankl ao afirmar que a resiliência e o sentido da vida estão vinculados, também, à vida espiritual.

Em Solzhenitsyn, a espiritualidade o permitiu enxergar o sofrimento que estava vivendo como uma oportunidade de crescimento espiritual (McKAY, 1971). Pois ele tinha a convicção de que fora salvo por um propósito, e que a vida dele tinha um sentido superior às trivialidades cotidianas (TOWNLEY, 1998). Dessa forma, fazendo do sofrimento uma experiência de vida que tenha um caráter redentor (PARNELL, 1980), de modo que "a graça de Deus pudesse brilhar em uma alma madura" (MAHONEY, 2019).

\section{CONSIDERAÇõES FINAIS}

Faz-se necessário dizer que encontrou-se dificuldade em levantar dados em língua portuguesa acerca da vida de Alexander Solzhenitsyn; eram praticamente inexistentes. E mesmo os materiais encontrados em língua inglesa encontrou-se dificuldade, pois, em sua maioria referiam-se à literatura de Solzhenitsyn e não à sua vida. Houve, então, a tentativa de mitigar essa dificuldade e encontrar um meio de aproveitar os escritos em língua inglesa.

Para isso, tomou-se os próprios livros de Solzhenitsyn, que embora possuam um conteúdo ficcional ainda que em parte -, e que por isso não foram tomados como referências para a discussão de suas experiências, permitiram ao pesquisador compreender o contexto do em que o escritor escrevera a obra e o contexto em que os personagens estavam inseridos. Pois as impressões pessoais do literário russo estão arraigadas em vários de seus escritos (SPIVAKOVSKY, 2003). A isso, Solzhenitsyn denomina "polifonia", que permite a convergência de percepções individuais com o ponto de vista do personagem da obra (SPIVAKOVSKY, 2003).

Em contrapartida, há uma vasta literatura acerca de Viktor Frankl, tanto as escritas por eles - muitas encontradas no idioma português - e de outros autores que tratam dos conceitos preconizados por Frankl, e que, além disso, dão um relato biográfico do autor.

Apesar das dificuldades encontradas, a realização do trabalho se mostrou proveitosa. A leitura das obras destes dois autores e a relação com suas vivências permitiu ao pesquisador, e permite ao leitor também, uma expansão na comprensão desses fenômenos [sofrimento e superação]. Ademais, a finalização deste trabalho permite que haja uma literatura no idioma português e que certamente beneficiará outros pesquisadores, permitindo que futuras pesquisas não incorram nas mesmas dificuldades das quais esta esteve sujeita.

Além disso é desejável que novos trabalhos a respeito deste tema tão importante sejam realizados, talvez de uma forma mais direta ao público por meio de pesquisas de campo e com outros instrumentos. Pois, apesar do intento desta monografia ter sido discutir a problemática do sofrimento psíquico e da superação

\footnotetext{
${ }^{11}$ God of the Universe! I believe again! Though I renounced You, You were with me!
} 
a partir das experiências de Alexander Solzhenitsyn e Viktor Frankl, toda a explanação aqui presente pode ser como um exórdio para futuras pesquisas, já que os conceitos não se limitam à esta ou àquela pessoa, mas podem ser aplicados em uma população geral. No entanto, cabe dizer que fazer uma asserção como esta não implica supôr que esta pesquisa tenha falhado em responder seus objetivos. 0 que se vê, pelo contrário, é que este trabalhou logrou aquilo a que se propunha.

\section{REFERÊNCIAS}

[1] ALEXOPOUlOS, G. Destructive-Labor Camps: Re-thinking Solzhenitsyn's Play on Words. Kritika: Explorations in Russia and Eurasian History, v. 16, n. 3, p. 497-524, 2015.

[2] AQUINO, F. Uma história que não é contada. 5. ed. Lorena: Cléofas, 2009.

[3] AQUINO, Thiago A. A.. Viktor Frankl: para além de suas memórias. Phenomenological Studies Revista da Abordagem Gestáltica, Goiânia, v. 26, n. 2, p. 232-240, 2020. DOI: 10.18065/2020v26n2.10.

[4] BRANDÃO, S. R. O sentido do sofrimento como doação de si. CEMrOC-Feuso/IJI-Universidade do Porto, São Paulo, n. 26, p. 7-14, 2011.

[5] BERNARDINO, A. L. F.; LIMA, C. C.; PALMIEIRI, G. F. 0 utilitarismo: a questão moral acerca da felicidade. Jornal Eletrônica: Faculdades Integradas Vianna Júnior, v. 12, n. 2, jul-dez, 2020.

[6] BRENCIO, F. Sufferance, Freedom and Meaning: Viktor Frankl and Martin Heidegger. Studia Paedagogica Ignatiana, v. 18, n. 1, p. 217-246, 2015.

[7] BRITANNICA. Aleksandr Isayevich Solzhenitsyn: russian author, 2020. Disponível em: https://www.britannica.com/biography/Aleksandr-Solzhenitsyn. Acesso em 03 ago 2020.

[8] CAlvetTI, P. U.; MUller, M. C.; NUNES, M. L. T. Psicologia da Saúde e Psicologia Positiva: Perspectivas e Desafios. Psicologia, Ciência e Profissão, Brasília, v. 27, n. 4, p. 706-717, 2007.

[9] CAVALCANTI, S. R. A sobrevivência da cultura: uma análise na obra de B. F. Skinner. Dissertação (Mestrado). Programa de Estudos de Pós-Graduandos em Psicologia Experimental: Análise do Comportamento, PUC-SP, 2014.

[10] CUASAY, B. Our souls can grow under suffering. The Irish Rover, out 2018. Disponível em: https://irishrover.net/2018/10/our-souls-can-grow-under-suffering/. Acesso em: 29 jul 2020.

[11] DIÁLOGOS com Solzhenitsyn (Legendado) - Aleksandr Sokurov - Parte 4. Aleksandr Sokurov. [S.l.: s. n.], 2015. 1 vídeo (50mi06s). Publicado pelo canal Logos Filmico. Disponível em: http://youtu.be/3DAKkEtmxAM. Acesso em: 28 jul 2020.

[12] DOS SANTOS, Mário Ferreira. Psicologias. 2. ed. São Paulo: Livraria Editora Logos Ltda, 1956.

[13] FRANKL, Viktor E. Em busca de sentido: um psicólogo no campo de concentração. Tradução de Walter O. Schlupp e Carlos C. Aveline. Porto Alegre, 1987.

[14] FRANKL, Viktor E. Psicoterapia para todos: Uma psicoterapia coletiva para contrapôr-se à neurose coletiva. Tradução de Antônio Estêvão Allgayer, Petrópolis, Vozes, 2018.

[15] FREUD, S. O mal-estar na civilização. 1930. In: FREUD, S. 0 mal-estar na civilização e outros textos (1930-1936). Obras completas de Sigmund Freud Vol XVIII. Tradução de Paulo César de Souza, 2010.

[16] FOSSATI, P. Por uma logobiografia: possíveis contribuições de Viktor E. Frankl para uma história de vida com sentido, p. 89-108, In: ABRAHÃO, M. H. M. B. (Auto) Biografia e formação humana. Porto Alegre: EDPUCRS, 2010.

[17] GALVÃO, Taís Freire; PEREIRA, Maurício Gomes. Revisões sistemáticas da literatura: passos para sua elaboração. Epidemiol. Serv. Saúde, Brasília, v. 23, n. 1, p. 183-184, 2014.

[18] GIL, Antônio Carlos. Como classificar as pesquisas. Como elaborar projetos de pesquisa. v. 4, p. 4445, 2002.

[19] GERMER, C. K. Mindfulness: O que é? Qual sua importância. In. GERMER, C. K.; SIEGEL, R. D.; FULTON, P. R. Mindfulness e psicoterapia. Porto Alegre: Artmed, 2015.

[20] GUSMAN, A. C, et al. A dor e o controle do sofrimento. Revista de psicofisiologia. v. 1, n. 1, 1997.

[21] JOÃO PAULO II. Carta Apostólica Salvifici Doloris. 1984. 
[22] KAMATI, A. T. O sentido do sofrimento humano à luz da Carta Apostólica "Salvifici Doloris". 2014. Tese (Mestrado em Teologia) - Faculdade de Teologia, Universidade Católica Portuguesa, Braga, 2014.

[23] KEMPIS, T. Imitação de Cristo. Petrópolis: Vozes, 2015.

[24] MAHONEY, D. J. Solzhenitsyn: politics and the ascent of the soul. Intercollegiate studies institute. Maio 2019. Disponível em: https://modern-age/solzhenitsyn-politics-and-the-ascent-of-the-soul/. Acesso em: 29 jul 2020.

[25] MANO, R.; COSTA, I. "Deus não morreu e o diabo existe": reflexões fenomenológicas sobre a experiência espiritual e o sofrimento psíquico grave. Revista da Abordagem Gestáltica - Phenomenological Studies, v. 21, n. 2, p. 162-176, jul-dez, 2015.

[26] MATIAS, V. Da ideologia. Disponível em: http://contraosacademicos.com.br/da-ideologia/. Acesso em: 01 maio 2020.

[27] McKAY, J. N. Alexander Solzhenitsyn's novel The First Circle. 1965. Tese (Mestrado em Artes) Department of Slavonic Studies, University of British Columbia, Vancouver, 1971.

[28] MELICH, J. C. Homo patiens: ensayo para una antropología de sufrimiento. Ars Brevis, p. 166-188, 2008.

[29] MORSON, G. S. How the great truth dawned: on the Soviet virtue of cruelty. The New Criterion. Set 2019. Disponível em: https://newcriterion.com/issues/2019/9/how-the-great-truth-dawned. Acesso em: 30 jul 2020.

[30] MIGUEZ, E. M. Educação em Viktor Frankl: entre o vazio existencial e o sentido da vida. 2015. Tese (Doutorado) - Faculdade de Educação, Universidade de São Paulo, São Paulo, 2015.

[31] MOREIRA, N.; HOLANDA, A. Logoterapia e o sentido do sofrimento: convergências nas dimensões espiritual e religiosa. Psico-USF, Itatiba, v. 15, n. 3, p. 345-356, set./dez. 2010.

[32] NEVES, D. A. O critério utilitarista será adequado para situação de risco? Rev. Bras. Saúde Mater. Infantil, v. 10, suple. 2, p. 347-353, dez. 2010.

[33] NEVES, José Luis. Pesquisa qualitativa: características, usos e possibilidades. Caderno de pesquisas em administração. v.1, n. 3, 1996

[34] NOVELli, P. G. A. A dor e o sofrimento em Hegel: os não-verbetes da Enciclopédia. Ágora Filosófica, ano 12, n. 1, p. 199-233, jan/jun. 2012.

[35] OLIVEIRA, A. V. Pós-Modernidade e sofrimento psíquico: análise feita a partir de depoimentos de psicólogos clínicos. 2006. Dissertação (Mestrado em Psicologia) - Faculdade de Psicologia, Pontifícia Universidade Católica de Minas Gerais, Belo Horizonte, 2006.

[36] OLIVEIRA, C. C. Para compreender o sofrimento humano. Revista bioética, Brasília, v. 24, n. 2, p. 225-234, 2016.

[37] PARnElL, I. L. Political and moral themes in the works of Alexander Solzhenitysn. 1980. Tese (Master of Arts) - Faculty of the Department of Government, College of Willia, and Mary, Virginia, 1980. DOI: https://dx.doi.org/doi:10.21220/s2-sqe1-6046. Disponível em: https://scholarworks.wm.edu/etd/1539625102/. Acesso em: 3 ago 2020.

[38] PETERS, G. Do existencialismo sociológico à epistemologia insana: a ordem social como problema psíquico. 2014. Tese (Doutorado em Sociologia) - Instituto de Estudos Sociais e Políticos, Universidade do Estado do Rio de Janeiro, Rio de Janeiro, 2014.

[39] ROCCA, S. M. Resiliência: uma perspectiva de esperança na superação das adversidades. In: HOCH, L. C.; ROCCA, S. M. Sofrimento, Resiliência e Fé - Implicações para as relações de cuidado. Editora Sinodal, 2007.

[40] RODRIGUES, L. A.; BARROS, L. A. Sobre o fundador da Logoterapia: Viktor Frankl e sua contribuição à psicologia. Revista EVS-Revista de Ciências Ambientais e Saúde, v, 36, n. 1, p. 11-31, 2009.

[41] ROSAS, P. S. O dilema da Psicologia contemporânea. Psicologia: ciência e profissão, Brasília, v. 30, p. 42-49, 2010.

[42] SANTA CLARA, C. J. S. Melancolia: da Antiguidade à Modernidade. Uma breve análise histórica histórica. Revista de saúde mental e subjetividade UNIPAC, v. 7, n. 13, 2009. 
[43] SANTOS, B. B. Cultura do consumo: da promessa de felicidade aoo sofrimento psíquico. Latitude. v. 11, n. 1, p. 295-333, 2017.

[44] SANTOS, J. A. dos; PEDROSA-PÁDUA, LÚCIA. Sofrimento e sentido no mundo contemporâneo: um diálogo entre o Homo Patiens de Viktor Frankl e a Carta Apostólica Salvifici Doloris, de João Paulo II. 2018. Dissertação (Mestrado em Teologia) - Pontifícia Universidade Católica do Rio de Janeiro, 2018.

[45] SCAMELL, M. Russia's literary light who illuminated dark world of Soviet regime. The Guardian. $2008 . \quad$ Disponível em: https://amp-theguardiancom.cdn.ampproject.org/v/s/amp.theguardian.com/books/2008/aug/04/nobelprize/russia2?amp_js_v=a 2\&amp_gsa=18usqp=mq331AQFKAGwASA\%3D\#aoh=16008070354572\&referrer=https\%3A\%2F\%2Fw ww.google.com\&amp_tf=Fonte $\% 3 \mathrm{~A} \% 20 \% 251 \% 24$ s\&ampshare=https\%3A\%2F\%2Fwww.theguardian.co m\%2Fbooks\%2F2008\%2F04\%2Fnobelprize.russia2. Acesso em: 27 set 2020.

[46] SEBOLD, R. L. Reflexões sobre felicidade e sofrimento: Alguns litorais. Trabalho de Conclusão de Curso (Bacharel em Psicologia), Universidade Federal do Rio Grande do Sul, 2013.

[47] SHANTALL, H. M. A heuristic study of the meaning of suffering among holocaust survivors. 1996. Tese (Doutorado em Literatura e Filosofia). Universidade de Joanesburgo, África do Sul, 1996.

[48] SILVEIRA, D. R.; MAHFOUD, M. Contribuições de Viktor Emil Frankl ao conceito de resiliência. Estudos de Psicologia, v. 25, n. 4, p. 567-576, 2008.

[49] SOLZHENITSYN, Alexander. I am not afraid of death. [Entrevista cedida a] Christian Neef e Matthias Schepp. Der Spiegel. [S. l.] jul 2007. Disponível em: https://www.spiegel.de/international/world/spiegel-interview-with-alexander-solzhenitsyn-i-am-notafraid-of-death-a-496211-amp.html. Acesso em: 28 jul 2020.

[50] SOLZHENITSYN, Alexander. The Gulag Archipelago: An Experiment in Literary Investigation III-IV. 6 ed. New York, Harper \& Row, 1975.

[51] SOLZHENITSYN, Alexander. The main dates of life and work. Disponível em: https://www.solzhenitsyn.ru/zhizn_soljzenizina/biografii/711/. Acesso em: 28 jul 2020.

[52] SPIVAKOVSKY, P. Acadêmico Alexander Isayevich Solzhenitsyn. Sulf, literatura e linguagem, v. 62, n. 6, p.62-67, 2003.

[53] THE NOBEL PRIZE. Alexandr Solzhenitsyn: Biographical, 2020. Disponível em: https://www.nobelprize.org/prizes/literature/1970/solzhenitsyn/biographical/. Acesso em: 28 jul 2020.

[54] TOWNLEY, D. A. Aleksandr Solzhenitsyn in American historiography: A Christian critic and his secular audience. Eletronic Theses and Dissertations. University of Windsor, Russia, 1998.

[55] VERAS, J. F. Adoecimento psíquico em mulheres portadoras do vírus HIV: um desafio para a clínica contemporânea. Psicologia: ciência e profissão. v. 27, n. 2, Brasília, 2007. 


\section{Capítulo 9}

\section{Análise psicológica da saúde mental de professores da rede pública de ensino}

\section{Paulo Melo Bernardes}

Resumo: A atmosfera emocional em um ambiente de sala de aula é importante para as experiências de todos os alunos. Essa atmosfera é afetada pela estabilidade emocional do professor. 0 professor com problemas pessoais de saúde mental pode ter um efeito prejudicial sobre todos os alunos que estão associados a ele. Há uma variedade de cursos e fatores que contribuem para problemas de saúde mental. É importante que sejam identificadas medidas para ajudar os professores com problemas emocionais. 0 objetivo geral do presente trabalho é discutir o sofrimento psíquico em professores da rede pública de ensino. Este trabalho foi realizado através de uma pesquisa bibliográfica qualitativa, método que fornece uma apreciação de estudos científicos de forma sistemática e ampliada. Foram utilizados 28 artigos, sendo 19 em língua portuguesa e 3 em língua espanhola. Também recorreu-se à 3 trabalhos de conclusão, 3 dissertações e duas teses. Os resultados mostram que o fantasma da doença mental assombra as salas de aula de milhares de professores. Nos estudos coletados, verifica-se um desconforto psicossocial que ninguém está tratando. A saúde mental não é mencionada em nenhum Ministério da Educação, nem nos discursos dos sucessivos ministros do ramo. Os estudos ora apresentados mostraram que muitos professores sofrem de ansiedade, medo, angústia, entre outros problemas, que não se enquadram na lógica dos tratamentos, que se recusam a desabilitar por problemas psicológico e que retarda a possibilidade de encaminhar para um especialista a quem consulta por estes motivos.

Palavras-chave: Professores; Saúde Mental; Sofrimento psíquico. 


\section{INTRODUÇÃO}

A doença mental no Brasil tem um impacto significativo na sociedade individualmente, social e economicamente. Um estudo de Dejours (2012) revelou que aproximadamente um em cada cinco adultos brasileiros com idades entre 16 e 85 anos experimentará pelo menos uma das formas comuns de doença mental em qualquer ano e $45 \%$ sofrerão de transtornos mentais ou de uso de substâncias em sua vida. Uma pesquisa com mais de 5.000 trabalhadores indicou que $25 \%$ dos trabalhadores tiravam folga a cada ano por razões relacionadas ao estresse. Esses números resultam em um drástico dreno na economia, com custos elevados devido a despesas de saúde, redução da participação da força de trabalho e diminuição da produtividade no local de trabalho.

A saúde mental e o bem-estar de professores pode influenciar a saúde mental e o bem-estar de seus alunos, bem como resultados na área educacional. No entanto, a profissão docente é comumente relatada como uma das ocupações mais estressantes. No Brasil, pessoas que trabalham no setor de educação relatam níveis estatisticamente mais altos de estresse relacionado ao trabalho e bem-estar inferior à média em todos os setores (RAMOS et al., 2020).

Os professores regularmente precisam lidar com muitas demandas concorrentes. Como resultado, eles podem facilmente colocar as necessidades de saúde mental e bem-estar de outras pessoas acima das suas próprias. No entanto, é importante que os professores tenham tempo para priorizar sua própria saúde mental e bem-estar, para seu benefício e de toda a comunidade escolar (GOUVÊA, 2016).

De acordo com Souza e Leite (2011), as atividades de saúde mental e bem-estar para professores devem ser contínuas e holísticas. Incorporar atividades de autocuidado, como atividade física, conversar com os amigos e estabelecer limites no trabalho pode ajudar os professores a melhorar e manter seu bem-estar pessoal.

Para os autores supracitados, essas atividades devem ser combinadas com o conhecimento e o acesso a redes formais de apoio, como programas de assistência ao funcionário. Culturas de trabalho de apoio e confiança também terão um impacto positivo na saúde mental e no bem-estar de professores e outros funcionários da escola.

Nem sempre é uma tarefa fácil, mas é necessária para que o ambiente de ensino-aprendizagem seja positivo. Administradores escolares, programas de preparação de professores, colegas de ensino e autoanálise, todos devem desempenhar um papel na identificação do ensino, essa é uma tarefa que nenhuma pessoa ou agência pode realizar sozinha, embora, muitas vezes seja considerada uma questão desconfortável com a qual lidar, todos os educadores devem se tornar cada vez mais conscientes do problema e estar dispostos a trabalhar em prol da saúde emocional de todos os professores (GOUVÊA, 2016; RAMOS et al., 2020).

Esta pesquisa tem grande relevância para a sociedade, uma vez que visa mostrar a realidade dos professores, tanto em sala de aula como extra sala, visando salientar para a sociedade em geral que o professor tem um valor importantíssimo na formação de uma sociedade e precisa ter condições adequadas de trabalho, assim como reconhecimento.

No que se refere às contribuições para a comunidade científica, este trabalho visa acrescentar conhecimento sobre as pesquisas no que diz respeito ao adoecimento psíquico de professionais professores, para que posteriormente este trabalho sirva de material de apoio para novas pesquisas científicas visando contribuir para o acervo de materiais referentes a este tema.

No que tange às contribuições para a comunidade universitária, este trabalho visa nortear as principais formas de sofrimentos psíquicos em professores da rede pública de ensino, diante disso os professores e coordenadores desta instituição terão conhecimento a respeito da qualidade de vida no trabalho e manutenção da saúde mental.

Para tanto, esta pesquisa estabeleceu como objetivo geral discutir o sofrimento psíquico em professores da rede pública de ensino. Definiu-se como metas os seguintes objetivos específicos: a) Investigar a situação da saúde mental de professores da rede pública de ensino; b) Levantar técnicas de intervenção psicológicas para a diminuição dos índices de afetação da saúde mental dos professores da rede pública. 


\section{REFERENCIAL TEÓRICO}

\section{Saúde mental e gestão}

A saúde mental é a resiliência emocional que permite desfrutar vida, e sobreviver a dor, decepção e tristeza. Saúde mental pode incluir uma série de experiências ou condições que afetam a saúde e bemestar de todos. A saúde mental é muito importante para o bem-estar geral. 0 bem-estar mental descreve a maneira como as pessoas pensam e sentem sobre elas mesmas e os outros, sua confiança, e sua capacidade de controlar as coisas na vida. Vai além de ter problemas de saúde mental, e não é sobre se ter ou não um diagnóstico de doença mental. Os problemas de saúde mental podem variar das preocupações que se experimentam como parte da vida cotidiana para condições sérias de longo prazo. A maioria das pessoas que experimentam problemas de saúde mental recuperam ou aprendem a gerenciá-los, especialmente quando eles recebem ajuda cedo (SCHAUFELI, 2014).

Liderança e gestão são fundamentais para promover a boa saúde mental no trabalho. A proteção e o aprimoramento da saúde mental não apenas atendem ao dever legal de cuidar do empregador e mostram que a organização é ética e responsável, como também reduz os possíveis custos de ausência de saúde mental e presenteísmo (SATO et al, 2006).

Liderança e gestão fortes são um fator-chave para garantir boa saúde mental e bem-estar aos funcionários. Para muitas pessoas, a forma como são tratadas pelo gestor e o comportamento de todos os líderes da organização faz uma enorme diferença na maneira como se sentem sobre si mesmos e sobre seu trabalho. Em um extremo, um gestor abusivo, negativo, inconsistente ou até mesmo desorganizado pode fazer com que aqueles que trabalham para eles sofram de problemas de saúde relacionados ao estresse (na verdade, pesquisas mostram que a falta de apoio gerencial é um dos fatores mais citados no estresse, ansiedade e depressão). No outro extremo da escala, sentir-se valorizado e apoiado por um gestor pode ajudar os indivíduos a lidar com todos os tipos de dificuldades, incluindo problemas de saúde mental que, de outra forma, prejudicariam seu desempenho (TORRES et al., 2013).

Além de seu comportamento ter um impacto direto na saúde mental dos funcionários, os gestores e líderes podem atuar como "guardiões" da presença (ou ausência) de condições de trabalho que apresentam riscos ao bem-estar mental dos funcionários. Isso pode ser feito evitando que uma carga de trabalho injusta seja imposta a um indivíduo, por exemplo, ou garantindo que a mudança organizacional seja bem comunicada. Os gestores também podem ajudar a garantir que os problemas de saúde mental sejam identificados precocemente se surgirem em sua equipe; e, se um indivíduo sofre de um problema de saúde mental, é mais provável que esse problema seja resolvido se o gerente estiver envolvido na solução (RAMOS; TITANNI; NARDI, 2008).

Evidências de pesquisas ligando administração e liderança à saúde mental e ao bem-estar dos funcionários cresceram dramaticamente ao longo da última década, ao ponto de serem tão bem apoiadas que quase parece evidente. No entanto, pode ser menos óbvio como alcançar uma boa liderança e gestão centrada nas pessoas (TORRES et al., 2013).

\section{Saúde mental dos professores}

A Organização Mundial da Saúde (OMS) entende por saúde não apenas a ausência de doenças ou condições, mas também o estado de completo bem-estar físico, mental e social. Além disso, observa-se que a saúde mental é um estado em que o indivíduo conhece e valoriza suas habilidades, é capaz de lidar com o estresse normal da vida e ter um desempenho produtivo e frutífero, gerando uma contribuição para sua comunidade. É por isso que deve ser considerada "saúde como um conceito integral que depende de um equilíbrio social, psicológico, fisiológico e biológico que influencia fortemente a maneira como os professores trabalham" (FERLA, et al., 2008).

A escola é o ambiente em que os mais novos aprendem a conviver, inevitavelmente neste local os alunos aprendem a interagir com outras pessoas e a ter um desenvolvimento psicossocial no qual os professores têm uma influência importante. Mesmo que não seja responsabilidade dos professores, faz parte da relação que ocorre em sala de aula.

Às vezes, os alunos passam por experiências difíceis ou vivem em ambientes muito complexos, o que torna a tarefa do professor um importante desafio. Para que os alunos tenham uma verdadeira rede de apoio, é necessário que os professores estejam em equilíbrio, que a sua saúde física e mental sejam as melhores, enquanto as suas necessidades são atendidas, só assim podem garantir que o desenvolvimento dos seus alunos seja o melhor (TOSTES et al., 2018). 
Portanto, considerando que por algumas décadas vem se destacando o impacto sobre alunos e professores e a importância das condições de trabalho na qualidade da educação e, especificamente, a influência das condições de trabalho no estado de saúde mental dos professores, é importante analisar em profundidade a influência do ambiente de trabalho no desempenho dos professores.

Tradicionalmente, considera-se que as boas condições de trabalho, adicionado à quantia recebida em troca do benefício de serviços, basta para que as pessoas realizem de forma adequada em seu campo de trabalho. No entanto, essa visão é insuficiente, pois minimiza o impacto que o ser humano tem em qualquer ambiente, "deixando além de uma área ampla e importante que influencia a qualidade de vida do corpo docente e sua capacidade de desenvolver respostas afetivas, emocionais e humanos que contribuem para um bom desempenho profissional "(PENTEADO, 2019).

Dito isso, pode-se dizer que o ambiente de trabalho é um conglomerado de situações, internas e externas, que definem e desencadeiam uma série de sentimentos de satisfação ou frustração no professor. Muitos professores se sentem sobre as condições em que devem realizar o seu trabalho, com muitas deficiências que não foram sanadas, embora eles se manifestam há décadas; isso faz com que os professores também questionam-se como profissionais e sentem pouca satisfação com o seu trabalho (SOUZA, 2017).

Apesar da sua importância, o trabalho do professor é desgastante mental e emocionalmente, enfim a convivência constante com tantas pessoas, a responsabilidade e o convívio diário em contextos, por vezes muito complicados, atingem qualquer pessoa. Muito mais para aqueles que têm responsabilidades da magnitude de professores. Este, porém, é um dos fatores menos considerados na educação, por isso é importante que cada um cuide da melhor forma possível sua saúde (TOSTES et al., 2018).

Nas diferentes condições que afligem os professores, em termos de sua saúde mental, vários autores referem-se a este conjunto como "Desconforto do Professor". É assim que alguns autores usam a palavra desconforto como termo inclusivo que reuniria os sentimentos dos professores antes de uma série de situações imprevistas no desenvolvimento de seu trabalho (SILVA; SIMONETTO, 2016). Como indica os autores citados anteriormente, desconforto profissional, e principalmente do professor, está se tornando cada vez mais importante, aludindo a fenômenos e experiências de trabalhadores que, embora não constituam uma doença evidente, e portanto, não são motivo de afastamento médico, alteram profundamente o bem-estar dos trabalhadores e da qualidade do seu trabalho que, no caso dos professores, influencia diretamente os alunos e sua aprendizagem.

Educadores, segundo Diehl (2016), podem sentir frustração e ansiedade ao enfrentar um aluno com problemas comportamentais de aprendizagem ou deficiência de atenção porque, além da situação em si, sentiriam a pressão de gestores e colegas. Também indica que seria possível encontrar um aumento da tensão e ansiedade nos professores quando devem confrontar um aluno com distúrbios de comportamento, uma vez que o professor sabe que o aluno estará restringindo suas tarefas de ensino habituais, o que acarretaria uma sobrecarga no seu trabalho.

\section{A saúde mental dos profissionais docentes: principais riscos ocupacionais}

Os profissionais docentes estão expostos a diversos riscos ocupacionais, porém, segundo diferentes investigações, o estresse no trabalho e a saúde mental são os aspectos que mais afetam sua saúde.

Além da própria carga de trabalho, os professores enfrentam inúmeras situações estressantes no dia a dia. $\mathrm{O}$ aumento das demandas das famílias aos professores, as críticas sociais a que estão continuamente expostos, culpando-os em muitos casos pelo fracasso escolar, tendo que enfrentar e resolver conflitos entre alunos, ter que trabalhar com alunos muitas vezes desmotivados e a falta de apoio e/ou recursos na realização de seu trabalho são alguns dos principais aspectos que levam muitos profissionais da área docente a uma situação conhecida como "Síndrome de Burnout".

Entre os primeiros 10 fatores de risco ocupacionais identificados nos professores, 8 são de natureza psicossocial e têm impacto direto na saúde mental, conforme destacam Silva e Simonetto (2016) e Petroni; Souza (2017) e estão elencados abaixo: Complexidade da atenção aos alunos com déficits ou ritmos de aprendizagem muito diferentes (falta de suporte para esses problemas); exigência e delegação de problemas e conflitos que correspondem às famílias ou outros setores da sociedade e não à escola; excesso de horas letivas com falta de tempo para atender os alunos, familiares, tarefas administrativas; problemas disciplinares; falta de reconhecimento social; esforço vocal; falta de colaboração / cooperação entre colegas; excessiva demanda burocrática; posturas de trabalho inadequadas e/ou forçadas; questionamento e desconfiança de todos em relação ao trabalho do corpo docente. 
Assim, não é de surpreender que o estresse, a ansiedade e a depressão ocupem um lugar de destaque na lista de doenças que causam afastamento dos professores.

O desgaste profissional e o desconforto do professor de e para a tarefa tem sido um problema que aumenta ao longo dos anos, uma vez que o estresse dos professores tem reagido às mudanças ao longo da história e aos processos de globalização. 0 que tem levado o professor a assumir papéis que antes eram de responsabilidade de terceiros, como a participação ativa dos pais no processo escolar. Hoje, as famílias são constituídas por membros externos ao núcleo, de forma que, em muitos casos, a responsabilidade educacional recai apenas sobre a escola, pois falta comunicação assertiva em casa, o que expõe os alunos a riscos iminentes como dependência de drogas, gangues e violência entre pares. Nesta fase, é o professor que deve identificar os problemas, monitorá-los, ensinar valores e ser subjetivo entre a objetividade do processo educacional, como aponta Esteve (2017).

O professor deve manter um equilíbrio mental em todas as suas dimensões pessoais para dar um desempenho completo de qualidade em sala de aula, o que implica que seu lar, sua projeção profissional, sua vida material, sua autoestima e sua espiritualidade devem produzir um grande desempenho para não se afogar na sala de aula. Infelizmente, hoje os professores assumem os episódios de estresse como algo natural e, segundo diversos pesquisadores (VIVES, 2015; ANDRADE; SOUZA, 2018), os professores correm o risco constante de sofrer de doença mental, e o mais preocupante é que existe um desconhecimento dos regulamentos e fiscalização das doenças ocupacionais e uma clara falta de prevenção por parte dos empregadores dos professores. Gasparini (2016) concordam que "Os professores estão enlouquecendo porque as demandas são tantas e tão desproporcionais que os professores não conseguem mais atender a tantas demandas".

\section{Bem-estar versus saúde organizacional escolar}

A literatura sobre o tema da saúde e do bem-estar nas organizações abrange diferentes perspectivas sobre esta questão: física, psicológica e mental. 0 amplo espectro que varia a partir dessas perspectivas gerou uma variedade de definições para o bem-estar e a saúde organizacional.

0 trabalho é o local onde despendemos cerca de um terço do nosso tempo, sendo um dos ambientes que mais afeta a saúde física e mental das pessoas, influenciando significativamente não só na vida profissional, mas também em múltiplos aspectos da vida pessoal, como a relação com o parceiro ou o desempenho escolar dos filhos (TOSTES et al., 2018)

Embora em algumas ocasiões o trabalho possa ser considerado uma fonte de satisfação e realização pessoal, ao contrário de demissão ou desemprego, em outras, o local de trabalho pode ter um efeito negativo marcante sobre o bem-estar, o emprego e a saúde mental dos trabalhadores.

A este respeito, de acordo com a Organização Internacional do Trabalho - OIT-, as interações entre o ambiente de trabalho, o conteúdo do trabalho, as condições da organização e as capacidades, necessidades, cultura do trabalhador, bem como aspectos pessoais externos para o trabalho, constituem fatores de risco psicossocial que, dependendo das percepções e da experiência pessoal de trabalho, podem influenciar a saúde, o desempenho e a satisfação no trabalho.

Tostes et al. (2018) classificam os fatores de risco psicossocial em dois grupos: a) aqueles relacionados à organização, conteúdo e desempenho do trabalho (sobrecarga quantitativa ou qualitativa da tarefa, distribuição do tempo de trabalho e períodos de pausas e descanso, horário de trabalho e turnos, funções e tarefas, ritmo de trabalho, monotonia, autonomia, carga mental, treinamento, responsabilidade, desempenho de função, comunicação no trabalho, estilo de comando, participação na tomada de decisões, condições de trabalho, possibilidade de progressão na carreira); e b) aqueles relacionados às interações humanas (relações interpessoais no trabalho, com superiores, subordinados, colegas e/ou com usuários ou clientes e situações de assédio no local de trabalho).

Estes riscos de origem psicossocial são atualmente considerados um dos principais problemas de saúde ocupacional enfrentados pela população ativa do Brasil (RAMOS et al., 2020), e a sua falta de prevenção pode acarretar significativos custos humanos e econômicos, tanto para o trabalhador afetado, cuja qualidade de vida está diminuída, bem como para a organização e a sociedade como um todo.

Especificamente, um dos maiores desafios de saúde e segurança enfrentados pelas organizações no Brasil hoje é o estresse relacionado ao trabalho. Este grave problema, que no país atinge 59\% dos trabalhadores, surge quando existe uma incompatibilidade entre as exigências do posto de trabalho ou do ambiente de trabalho e as capacidades, recursos e necessidades do trabalhador. Seu impacto pode variar dependendo 
da resposta individual, embora a exposição prolongada afete negativamente o bem-estar e possa contribuir para o desenvolvimento de uma série de consequências prejudiciais à saúde, incluindo problemas físicos (por exemplo, doenças cardiovasculares e distúrbios musculoesqueléticos), comportamentos de risco à saúde - como uso e abuso de álcool, tabagismo e distúrbios do sono - bem como distúrbios mentais e comportamentais, principalmente burnout, ansiedade e depressão. A gravidade desta última já foi destacada pela Organização Mundial da Saúde (OMS), que coloca a ansiedade e a depressão como a segunda causa de doenças relacionadas ao trabalho, atrás das doenças musculares, prevendo que, em 2020, eles serão o principal motivo de afastamentos em todo o mundo (TOSTES et al., 2018).

No nível organizacional, o estresse, em conjunto com os problemas mencionados, se traduz em dificuldades no desempenho do trabalho que acarretam custos significativos: menor produtividade, maior taxa de absenteísmo e presenteísmo, aumento do número de dias de folga no curto e longo prazo, entre outros. O impacto destes fatores tem um custo anual para as empresas de cerca de 1.220 reais por trabalhador (RAMOS et al., 2020).

0 alcance das consequências do estresse também se reflete no ambiente familiar: alguns estudos têm apontado o impacto que ele pode ter no relacionamento do casal, bem como na atitude dos pais em relação aos filhos e problemas de seu comportamento na escola.

Todos esses indicadores mostram que a situação quanto ao desenvolvimento de organizações saudáveis e a promoção da saúde no trabalho não é tão positiva quanto deveria e, portanto, é importante que as políticas e legislações dos governos, bem como iniciativas públicas e privadas contribuem para a promoção de empresas saudáveis. Este último, por meio do desenvolvimento de políticas e práticas de saúde e segurança, e da promoção de melhorias nos sistemas e condições de trabalho (HERCULANO, 2017).

França e Rodrigues (2012) definem o bem-estar como a forma de criar um ambiente para promover um estado de satisfação que permita que os funcionários floresçam e obtenham todo seu potencial em benefício de si mesmos e de sua organização. 0 bem-estar dos funcionários tem aspectos físicos, mentais e emocionais da saúde dos funcionários em interações complexas que atuam para afetar as pessoas.

O bem-estar é uma construção biopsicossocial mais ampla que inclui: saúde física, mental e social. Essa dimensão na organização é benéfica para as pessoas dentro da organização, bem como para aqueles que estão fora dela; isso torna a organização mais produtiva, atraente e responsável pela condição dos funcionários.

Mais e mais organizações em todo o mundo estão trabalhando para criar um equilíbrio entre a maximização da produtividade e o risco de burnout para os funcionários que podem cometer erros que envolvam custos ou demissões. 0 entendimento de uma abordagem holística que sustenta o bem-estar e o desenvolvimento de iniciativas relacionadas a esta questão e a sua integração com outras políticas de RH podem fornecer uma abordagem para apoiar esse equilíbrio (TELLES; PIMENTA, 2009).

Para França e Rodrigues (2012), a diferença entre saúde e bem-estar reside na área que abrange cada um dos dois conceitos, em contexto organizacional. 0 termo saúde refere-se a sintomas físicos e fisiológicos em um contexto médico (como o diagnóstico de doenças). Aplicando-o no contexto organizacional, a ênfase é nos indicadores fisiológicos e psicológicos que são usados para avaliar a saúde dos funcionários. O bem-estar é um conceito mais amplo, referente à pessoa como um todo. Além da saúde, o bem-estar inclui experiências de vida (satisfação de vida, alegria, felicidade, dentre outros) e, no contexto organizacional, inclui experiências gerais relacionadas ao trabalho (satisfação no trabalho, apego e outros.) e dimensões específicas (satisfação com colegas ou remuneração).

França e Rodrigues (2012), salientam que o tema da saúde e do bem-estar é muito importante para a prática organizacional, por várias razões. Primeiro, as experiências dos indivíduos no trabalho (física, emocional, mental, social) têm consequências diretas para ele. Além disso, essas experiências geram efeitos sobre o indivíduo além do local de trabalho. A interferência entre o trabalho e a vida privada é um tema muito estudado hoje em psicologia organizacional e de trabalho. Em segundo lugar, aumentou o interesse e a importância de outros fatores relacionados ao trabalho e que afetam a saúde e o bem-estar do trabalhador. Estes incluem agressão e violência no local de trabalho, assédio sexual, comportamentos disfuncionais no local de trabalho. Em terceiro lugar, a saúde e o bem-estar são uma questão importante que tem consequências para o indivíduo. Os pesquisadores e organizações reconhecem que a saúde e o bem-estar podem prejudicar os trabalhadores e a organização. Por exemplo, os trabalhadores com baixa 
saúde têm resultados significativamente mais baixos, podem tomar decisões erradas, são mais sujeitos ao absentismo. Para o indivíduo, tal situação induz custos fisiológicos, psicológicos e/ou emocionais.

Ao longo desse processo, Herculano (2017) considera fundamental o papel do psicólogo do Trabalho e Organização, cujo treinamento os capacita a contribuir efetivamente para programas destinados a melhorar o bem-estar psicológico no trabalho. Entre as suas funções, destaca-se a concepção e desenvolvimento de intervenções, a concepção de ambientes de trabalho psicologicamente saudáveis, produtivos e gratificantes (medir os níveis de bem-estar psicológico e avaliar os fatores que influenciam o local de trabalho; aconselhar sobre questões relacionadas com a Psicologia da gestão da mudança no local de trabalho, para que a mudança possa ocorrer de forma eficaz; projetar e treinar para ajudar a fortalecer a resiliência e a capacidade das pessoas para lidar com o trabalho exigente; ajudar as organizações a alcançar um bom ajuste entre pessoa e trabalho por meio de avaliação, seleção e desenvolvimento eficazes), apoio à gestão e liderança (ajudando os líderes a desenvolver estilos de gestão que equilibram o foco no desempenho de desempenho eficaz e bem-estar psicológico para garantir níveis sustentáveis de alto desempenho; fornecendo-lhes apoio e aconselhamento quando uma pessoa está ausente do trabalho devido a problemas de saúde ou foi diagnosticado com uma deficiência ou condição de saúde e está retornando ao trabalho; auxiliando os líderes de forma eficaz e sensata na abordagem de questões como absenteísmo, presenteísmo e problemas relacionados estresse; resolução de conflitos e apoio a pessoas e organizações sob pressão, por meio da construção de equipes ou suporte de gestão), apoiando as pessoas (ensinando os indivíduos a lidar com as dificuldades, e oferecendo aconselhamento e apoio para reabilitação e retorno ao trabalho).

\section{A psicologia como estratégia à saúde ocupacional}

Há um movimento crescente entre pesquisadores e profissionais da psicologia da saúde ocupacional para uma abordagem mais integrada e abrangente da saúde no local de trabalho. Esta abordagem abrangente visa encontrar um equilíbrio entre: por um lado, prevenir e gerenciar riscos e doenças e doenças ocupacionais no local de trabalho, enquanto, por outro lado, promover as características positivas do ambiente de trabalho que aumentam a vitalidade humana, pontos fortes e ótimos funcionando. A psicologia positiva da saúde ocupacional é um movimento que visa preencher essa lacuna no conhecimento e na prática (FRANÇA; RODRIGUES, 2012).

De acordo com Ferla et al. (2008), o campo da Psicologia da Saúde Ocupacional tem se concentrado tradicionalmente no exame e compreensão dos fatores de risco no local de trabalho (por exemplo, demandas de trabalho) e as doenças relacionadas ao estresse resultantes, como Burnout, doença mental, doenças cardiovasculares, para citar alguns. Consequentemente, a grande maioria das intervenções baseadas no trabalho principalmente na identificação e melhoria de problemas de saúde ocupacional e seus fatores de risco associados, em vez de ou complementada pela medição e reforço dos aspectos positivos do trabalho.

Os autores supracitados destacam ainda que há um consenso crescente entre os especialistas na área de que a promoção e cultivo de um local de trabalho saudável deve ser sustentado pela prevenção de riscos e doenças ocupacionais por meio da avaliação e gestão de riscos, mas esta abordagem pode ser (e deve ser) complementada por uma abordagem concentrada foco na promoção e cultivo de trabalhadores e locais de trabalho saudáveis. A psicologia da saúde ocupacional é um movimento que visa preencher essa lacuna no conhecimento e na prática.

A psicologia organizacional e do trabalho é um ramo da psicologia que estuda a relação entre estresse no local de trabalho e saúde e bem-estar mental e físico dos funcionários. 0 objetivo final da psicologia da saúde ocupacional é criar ou melhorar o ambiente de trabalho para que os funcionários desejem trabalhar cada dia. Ela também garante que os funcionários tenham a oportunidade de participar de um equilíbrio trabalho/vida saudável. Este ramo da psicologia combina as ciências da saúde ocupacional com a psicologia humana, em um esforço para criar um ambiente de trabalho seguro que promova a saúde e o bem-estar emocional, físico e mental (HELOANI; CAPITÃO, 2003).

Um psicólogo em saúde ocupacional projeta os cursos e atividades envolvidos com a relação entre o empregado e a organização, além de cuidar das condições de saúde mental dos funcionários. Esta é uma das maneiras mais simples de permitir que a administração saiba quais atribuições devem ser atribuídas aos empregados. Eles também são responsáveis pelo monitoramento do desempenho dos funcionários e suas condições mentais. Eles precisam estar familiarizados com as normas da cultura dentro das premissas organizacionais. Eles também devem estar familiarizados com a forma de lidar com as questões 
de agressão no local de trabalho, estresse e "bullying", para que eles possam cuidar dos problemas de saúde dos funcionários (FERLA et al., 2008).

Ramos et al. (2020) mencionam que dentre os aspectos particulares constituintes da satisfação com a vida, que era previamente definida como a avaliação positiva que a pessoa faz de sua vida em geral ou de aspectos particulares dela, está a satisfação com o trabalho, existindo evidências de que a felicidade leva a comportamentos que produzem sucesso no trabalho, nas relações sociais e na saúde. Assim, essa variável é entendida como um estado emocional positivo que resulta da percepção subjetiva da experiência de trabalho.

Pesquisa sobre comportamento organizacional e sua avaliação referem que a ideia de que melhorar a satisfação profissional dos seus colaboradores não é apenas um meio para atingir os objetivos organizacionais, mas também a possibilidade de as pessoas gozarem de melhor saúde está cada vez mais difundida nas organizações bem-estar mental e emocional. 0 exposto faz da satisfação no trabalho uma questão prioritária para avaliação e aperfeiçoamento em qualquer campo organizacional, com maior razão será no campo educacional, onde o trabalho realizado por educadores tem como matéria-prima pessoas em formação e o objetivo de orientar efetivamente seu desenvolvimento até que estejam completa e totalmente formados. Na verdade, há um interesse crescente no estudo da satisfação profissional dos professores na medida em que uma sociedade avançada deve assegurar que seus educadores sejam pessoas satisfeitas com o trabalho, uma vez que os benefícios que isso acarreta, tanto para os indivíduos quanto para as organizações, resultam na qualidade da educação oferecida e na reputação dos instituições educacionais (GOUVÊA, 2016; RAMOS et al., 2020).

Em suma, a satisfação no trabalho tem sido definida como o resultado de várias atitudes que um trabalhador tem em relação ao seu trabalho e à vida em geral. Se o trabalhador dispõe de recursos suficientes, tanto pessoais quanto profissionais, para fazer frente às demandas, seu estado psicológico será positivo com resultados como a satisfação no trabalho. Assim, a relação entre a Psicologia Positiva e a satisfação no trabalho é determinada pelas atitudes do indivíduo em relação a algo específico, podendo ser positivas ou negativas conforme facilitam ou dificultam a forma como a pessoa tem de enfrentar sua realidade a cada momento de sua vida. tempo de vida. Vale ressaltar que bons resultados não são alcançados apenas com boas atitudes, também há conhecimento, habilidade e experiência. Entre outros fatores, e é aí que surge a necessidade de treinar certas habilidades, mas isso não será suficiente se a atitude for inadequada, pois, dessa forma, fica difícil para as pessoas realizarem um trabalho satisfatório e menos desfrutar dos sucessos alcançados.

\section{PROCEDIMENTOS METODOLÓGICOS}

No presente estudo, optou-se por apresentá-lo em formato bibliográfico qualitativo, conforme poderá ser analisado no capítulo seguinte do presente trabalho. De acordo com a descrição dos autores Lima e Mioto (2007), na construção de um processo de pesquisa, os procedimentos utilizados devem ser rigorosamente definidos e esclarecidos. Sendo necessários três etapas:

Exposição dos métodos, é quando busca-se apresentar a questão norteadora escolhida para o encaminhamento da pesquisa, a construção do desenho metodológico e a escolha dos procedimentos em pesquisas bibliográficas os estudos exploratórios ou descritivos possibilita o amplo alcance de informações, a leitura apresenta-se como principal técnica para alcançar os objetivos da pesquisa, a apresentação do percurso da pesquisa obedecem aos critérios estabelecidos inicialmente, o caminho percorrido pelo pesquisador na coleta de dados. A análise da síntese, consiste na reflexão baseada nos objetivos do material proposto.

Os artigos foram coletados nas bases de dados SciELO e LILACS sobre a saúde mental dos professores da rede pública de ensino.

Para a realização da busca utilizou-se os descritores "saúde mental", "estresse psicológico" e "professores" e "educação". Os critérios de inclusão foram as pesquisas disponíveis on-line, referentes a trabalhos em língua portuguesa, inglesa e espanhola, com acesso gratuito da publicação na íntegra, publicados nos últimos cinco anos (2015-2020), que descrevam sobre a saúde mental dos professores da rede pública de ensino. Destaca-se que os critérios de exclusão foram: artigos pagos, que estavam apenas com o resumo disponível e que tiveram sua publicação anterior ao ano de 2015. 
Um pesquisador realizou a busca nos meses de julho e agosto de 2020 de maneira independente, respeitando os critérios de inclusão e exclusão. Os artigos potencialmente elegíveis foram lidos integralmente.

Foram utilizados 28 artigos, sendo 19 em língua portuguesa e 3 em língua espanhola. Recorreu-se à 03 trabalhos de conclusão, 3 dissertações e 02 teses.

No que se refere à Lei 9.610, que regulamenta os direitos autorais, entendendo-se sob esta denominação os direitos de autor e os que lhes são conexos, será respeitada a autenticidade das ideias originais das produções que serão analisadas por esta revisão.

\section{RESULTADOS E DISCUSSÃO}

\section{Saúde mental dos professores em ambiente laboral}

Gouvêa (2016) comenta que o meio ambiente, principalmente o contexto do trabalho, influencia dimensões relacionadas à saúde mental, como o estresse, satisfação pessoal e autoestima. Segundo Polonial (2015), vários conceitos são abordados em saúde mental no ambiente de trabalho. É possível encontrar o primeiro conceito de sofrimento psíquico, depressão, burnout em muitos estudos empíricos. A distinção entre esses termos acaba sendo, na maioria dos casos, um exercício difícil, pois todos eles abrangem a descrição de um desequilíbrio alcançados no nível psíquico do indivíduo, que são visíveis através da expressão de sintomas diferentes não específicos para uma determinada patologia. A definição e medição do sofrimento psicológico têm como objetivo ser mais geral, uma vez que engloba ao mesmo tempo muitos sinais de um desequilíbrio psíquico descrito e medido pelos conceitos de depressão e burnout.

Penteado (2019) e Moreira (2015) discorrem que a saúde como um conceito integral depende de um equilíbrio social, psicológico, fisiológico e biológico que influencia fortemente a maneira como os professores trabalham. Em conformidade Martins (2019) chama a atenção, para a importância dos aspectos contextuais e habilidades de situações sociais que podem influenciar negativamente na saúde mental e a importância de desenvolver competências profissionais que permitem alcançar uma saúde mental adequada em professores.

Tostes et al. (2018) e Ramos et al. (2020) descrevem a aflição como uma síndrome inespecífica que inclui sintomas relacionados à depressão, irritabilidade e ansiedade. Conceitualmente, é difícil distinguir claramente o sofrimento psicológico; depressão ou esgotamento, porque essas noções todas exigem a descrição de desequilíbrio, de um ataque ao nível de psique da pessoa manifestada por diferentes sintomas não específicos para uma determinada patologia. Definida como um conjunto de sintomas psicossociológicos e comportamentais distribuídos ao longo de um continuum de tempo. Tostes et al. (2018) ressalta ainda que a ligação entre a tensão psicológica e o trabalho dos professores são interessantes, considera esse sofrimento psicológico em quatro síndromes: depressão, ansiedade, agressão e problemas cognitivos; todas essas síndromes com exceção da agressividade, são variáveis de tensão.

De acordo com Gouvêa (2016) o conceito de angústia psicológica é apresentado como mais geral em sua definição e medição, porque compreende ao mesmo tempo os vários sinais de um desequilíbrio psíquico descrito e medido por noções de depressão e irritabilidade. A noção de sofrimento psicológico, portanto, se sobrepõe em muitas das perturbações da psique, refletidas pelas noções de depressão e esgotamento. Ressaltando ainda que o conceito de esgotamento é específico no sentido de que se refere a estados de fadiga e de exaustão ligada à situação de trabalho. No respectivo estudo de Martins (2019), o sofrimento psíquico demonstra que um aspecto do trabalhador não está trabalhando em todo o seu potencial e, portanto, para remediar este problema, a fim de reduzir o absenteísmo recorrente ou declínios nas habilidades intelectuais. É relevante mencionar que o termo "recorrência de sofrimento psicológico" usado para referir-se a um segundo episódio ou vários episódios subsequentes de sofrimento psíquico.

Nos respectivos estudos de Schmidt, et al. (2019) e Martins (2019), depressão, distúrbios nervosos e de concentração, dores de cabeça e irritabilidade representam os problemas diários sofridos pela maioria dos professores e que $86 \%$ das mulheres e $82 \%$ dos homens relataram sofrer de estresse. Setenta e cinco por cento dos professores protestam contra a opinião frequente de que os que estão nesta profissão levam uma vida fácil porque trabalham apenas a tempo parcial. Ao contrário, tendem a continuar trabalhando em casa entre 20 e 30 horas semanais para preparar as aulas, além de despender muito tempo no aperfeiçoamento profissional e cultural. A profissão docente deixou de ser atraente, a principal razão para 
isso é o esforço psíquico a que os professores são submetidos em função do clima prevalecente nas escolas.

Para Penteado (2019) o estresse não se deve, apenas à intensidade do trabalho docente, mas é consequência, sobre tudo, dos transtornos mentais e comportamentais dos alunos como ressaltaram, 85\% dos professores, outros $70 \%$ dos professores reclamam que os pais culpam a escola quando os filhos lhes dão problemas. À essa carga psíquica somam-se as enfermidades físicas como cardiopatias, problemas de circulação e tensões musculares no pescoço e nas costas, seguidas de alta tensão, além de distúrbios digestivos. Para Gasparini (2016) comentam os estudos referentes a uma ampla gama de doenças. Achados Distúrbios neuropsiquiátricos em primeiro lugar na extensão de licenças e quinto em novas licenças. Machargo (2015) descreve que inúmeros professores recorrem aos serviços de psicoterapia do Departamento de Educação. Días (2016) outrora investigou professores do ensino fundamental, médio e superior, e constatou que os professores são mais desalinhados do que a população em geral. Mais da metade manifesta sofrimento psicológico. Professores de ensino médio e superior se destacam pelo maior percentual de desajustes. Nos níveis de depressão, mais de um quinto dos professores universitários estão gravemente deprimidos, e em menor grau e intensidade o corpo docente dos outros demais níveis.

\section{Sofrimento psicológico e saúde física}

De acordo com Schmidt et al. (2020), o sofrimento psicológico, entendido como a experiência de sentimentos ou emoções desagradáveis que afetam o funcionamento do dia-a-dia, afeta uma parcela considerável da população em diversos países e é conhecido por levar para transtornos mentais mais graves e problemas de saúde física. Sofrimento psicológico ou afeto negativo é um dos fatores mediadores que mais claramente vinculam o estresse psicossocial ao problema de saúde física, especialmente afeto negativo, foi associada a uma redução na competência imunológica, bem como um elevado número de doenças infecciosas. Lourenço et al. (2020) ressalta que o efeito negativo influencia na saúde física e nas noções de controle sobre emoções básicas, indicam que estados específicos, como raiva, tristeza ou angústia ou medo, são respostas do indivíduo a eventos que o impedem de alcançar os objetivos e para o qual tem poucos mecanismos eficazes de enfrentamento ou controle. Viapiana et al. (2018), mencionam que o sofrimento psicológico (sintomas depressivos e nível de ansiedade) fez uma contribuição independente significativa para a previsão da percepção negativa simultânea e futura da saúde de alguém, além da saúde objetiva. À medida que os componentes ansiosos e depressivos do sofrimento psicológico se intensificam, uma visão negativa da vida inclui uma visão cada vez mais negativa da saúde. Por outro lado, a saúde subjetiva negativa previu independentemente tanto os sintomas depressivos quanto o nível de ansiedade, simultaneamente e ao longo do tempo, além da saúde objetiva. Assim, parece que a avaliação negativa da saúde anuncia sofrimento psicológico, manifesta-se como sintomas depressivos e ansiedade. Juntas, desenham o quadro de um círculo vicioso de avaliação negativa da saúde que leva à depressão e à ansiedade, que por sua vez levam a uma percepção negativa da saúde.

Ainda de acordo com Schmidt et al. (2020) e Lourenço et al (2020) é relevante obter um entendimento mais profundo dos fatores que influenciam os níveis de sofrimento dos indivíduos e dos diferimentos individuais na percepção de aspectos psicossociais, bem como nas reações dos indivíduos a esses aspectos para o desenvolvimento de políticas públicas de saúde eficientes e a formulação de intervenções paliativas eficazes.

\section{As intervenções psicológicas para a saúde mental dos professores}

De acordo com França e Rodrigues (2012) o crescente movimento de profissionais da psicologia da saúde ocupacional, visa encontrar um equilíbrio entre: prevenir, gerenciar riscos e doenças ocupacionais no local de trabalho, enquanto, por outro lado, promover as características positivas do ambiente de trabalho que aumentam a vitalidade humana, pontos fortes e ótimos funcionando. A psicologia positiva da saúde ocupacional é um movimento que visa preencher essa lacuna no conhecimento e na prática. Conforme Novaes (2019), a psicologia na educação inclui o conhecimento da avaliação e diagnóstico psicoeducacional, intervenção, prevenção, promoção da saúde e desenvolvimento de programas com foco no desenvolvimento de profissionais no contexto escolar. 


\section{O psicólogo escolar e a saúde mental de professores}

Moreira (2015) em seus estudos revela que ao longo dos anos, o papel do psicólogo educacional progrediu junto com as mudanças sociais e comunitárias. Já não se parece com avaliações padronizadas independentes e ser o 'especialista' em barreiras à aprendizagem. 0 afastamento do modelo médico promoveu uma abordagem holística mais arredondada no apoio a crianças, famílias e escolas. 0 envolvimento com as partes interessadas de uma forma mais contextual e significativa fez a educação avançar em várias direções. Segundo Lima (2015) e Rocha (2015) os psicólogos escolares são treinados exclusivamente para fornecer serviços de saúde mental e comportamental de alta qualidade no ambiente escolar para garantir que todos tenham o apoio de que precisam para ter sucesso na escola, em casa e ao longo da vida. Encontrados na ajuda a alunos com dificuldades de aprendizagem e apoiando os alunos em seu bem-estar emocional e social. Embora, muitos não estejam familiarizados com a ajuda e apoio deles para funcionários nas escolas. Problemas com alunos mal-comportados e pais complicados (fatores que têm um impacto negativo no bem-estar dos professores) são duas áreas nas quais eles podem oferecer apoio.

Lima (2015) defende que o papel do psicólogo educacional deve passar de uma perspectiva epistemológica baseada no modelo de simplicidade para uma perspectiva baseada na complexidade. Isso está mudando de uma visão filosófica que assume premissas, como a existência de uma realidade observável, gerenciável e individualista, ordenado e parcelado (simplicidade) a outro que concebe a educação de uma perspectiva socializada, valorizada, integrada, centrada nas complexas redes construídas por seus atores. Ou seja, um olhar compreensivo-prático e/ou crítico da realidade emergente (complexidade), que se traduz na busca pelo desenvolvimento e crescimento da instituição para e com seus atores. A posição metateórica do trabalho do psicólogo não é uma questão inócua em que se refere a definição do papel e do desempenho.

Este ponto não apenas permite ao psicólogo educacional esclarecer sua posição no sistema, mas que, além disso, tem efeitos diretos na forma como a comunidade a vê e nos resultados que são gerados a partir de seu desempenho. Análogo a isso, Rocha (2015), comenta a mudança gradual do ato instrumental do psicólogo, de perito e executor de políticas do sistema educacional, que tem o poder de avaliar, ajudar e resolver problemas de outros (alunos e professores) de relacionamento com os indivíduos fragmentados e descontextualizados, para uma ação que reflete o surgimento de fenômeno educacional e sua ocorrência, com foco no compartilhamento de visões e experiências para avaliar, ajudar e resolver problemas contando com a rede de interações vital com os demais sujeitos da comunidade educacional.

\section{Acompanhamento psicológico de professores}

Lourenço et al. (2020) comenta que a atenção à doença mental deve ser uma abordagem biopsicossocial, ou seja, levando em consideração os aspectos biológicos, psicológicos e sociais. Essa visão é essencial, pois permite descobrir as áreas que afetam a doença mental, especialmente as doenças graves. Na hora de decidir o tipo de tratamento a ser realizado, se estabelece uma estratégia prévia, um plano de tratamento, que inclua as diferentes necessidades do paciente, as condutas a serem realizadas e as prioridades. Às vezes, principalmente em problemas menos graves, pode ser realizado um único tipo de tratamento, que pode ser suficiente para desdobrar os próprios recursos do paciente e fazer ceder o que o incomodava. Outras vezes, é necessário recorrer a mais de uma modalidade de tratamento e, às vezes, a mais de um local. Essa abordagem por diferentes profissionais, de diferentes disciplinas e, às vezes, utilizando diferentes recursos é chamada de atendimento multiprofissional com continuidade do cuidado. Assim como, ressaltado por Ramos et al. (2020) que em doenças graves, é imprescindível que a equipe multiprofissional trabalhe corretamente e que haja articulação entre todos os profissionais envolvidos, inclusive com as famílias e recursos da comunidade que permitam ao doente não perder o vínculo com seu ambiente habitual, caso já o tenha feito, perdido ou nunca teve, as bases devem ser criadas para que ele exista.

Silva e Simonetto (2016) descrevem que o comprometimento da saúde mental do professor vem se elevando ao longo dos tempos, no entanto as estratégias de tratamentos para os professores que apresentam sua saúde mental comprometida não são suficientes para a demanda, deixando o professor à mercê de um sistema que, na sua maioria, os afasta de suas atividades ou os remanejam, mas não garante um tratamento de qualidade visando o restabelecimento de seu comprometimento mental. 


\section{Psicoterapias e a importância do psicólogo escolar}

Para entender os aspectos mais específicos do psicólogo escolar, é útil começar definindo a função. De acordo com Petroni e Souza (2017), os psicólogos escolares são profissionais treinados que trabalham para identificar, atender e superar as necessidades de aprendizagem e comportamentais de crianças em idade escolar. Segundo Abrapee (2020) a Psicologia Escolar é um importante campo de atuação da psicologia aplicada, visto que psicólogos escolares e educacionais são profissionais que atuam em instituições escolares e educativas, bem como dedicam-se ao ensino e à pesquisa na interface Psicologia e Educação.

No respectivo estudo de Ferreira (2015) comenta que psicologia escolar, prática geral da psicologia dos serviços de saúde, preocupa-se com as crianças, os jovens, as famílias, o processo de escolarização e todo corpo técnico da escola. Estes profissionais estão preparados para intervir a nível individual e do sistema e desenvolver, implementar e avaliar programas para promover ambientes de aprendizagem positivos para crianças e jovens de diversas origens e para garantir acesso igual a serviços educacionais e psicológicos eficazes que promovam o desenvolvimento da saúde. Para Andrada et al. (2019), os psicólogos escolares fornecem uma contribuição para o sistema educacional. Eles são duplamente treinados nas áreas de psicologia e educação, capazes de fornecer informações para funcionários da escola e pais em relação ao aspecto social / emocional e desafios de aprendizagem que as crianças enfrentam, como fornecer conhecimentos na área de mudança de sistemas. Frequentemente os psicólogos são relegados à área de educação especial, gastando muito de seu tempo avaliando os alunos para determinar a elegibilidade. Isso é em parte devido a modelos de financiamento utilizados por muitos distritos. No entanto, esses modelos falham fazer pleno uso da riqueza de informações e conhecimentos que o psicólogo escolar pode oferecer, especialmente no que diz respeito à saúde mental dos professores.

No conceito do Conselho Federal de Psicologia cabe ao profissional da psicologia dentro da escola, entre outras possibilidades

Envolver, em sua análise e intervenção, todos os segmentos do sistema educacional que participam do processo de ensino-aprendizagem.... Em conjunto com a equipe, colabora com o corpo docente e técnico na elaboração, implantação, avaliação e reformulação de currículos, de projetos pedagógicos, de políticas educacionais e no desenvolvimento de novos procedimentos educacionais. Analisa as características do indivíduo portador de necessidades especiais para orientar a aplicação de programas especiais de ensino. Realiza seu trabalho em equipe interdisciplinar, integrando seus conhecimentos àqueles dos demais profissionais da educação. (CFP, 2001, p. 9)

Como descrito por Ferreira (2015, p. 60) “(...) unir saberes torna-nos mais sábios e produtivos. É preciso descobrir novas perspectivas, dividindo e somando com o outro". A participação de um profissional da psicologia dentro da escola é uma ferramenta valiosa quando se pensa em trabalhar situações constantes na escola, quer seja para auxiliar ao aluno, quer seja para o professor. A psicóloga(o) escolar cabe integrar a teia de relação e fazer parte da equipe multiprofissional, que envolve o processo ensino/aprendizagem levando em conta o desenvolvimento global do estudante e da comunidade escolar.

De acordo com o levantamento realizado por Souza (2015), a composição do quadro de funcionários das respectivas Secretarias de Educação municipais, contabilizando 220 profissionais atuando no campo da Psicologia Escolar. O modo como esses serviços de Psicologia se organizam nesses municípios compreende a formação de equipes de psicólogos que atendem às demandas da rede ou por um único psicólogo que responde por todas as demandas encaminhadas pelas escolas, sendo as funções desenvolvidas categorizadas como: psicólogo, psicólogo escolar, psicólogo educacional e psicólogo da educação. As redes públicas de educação básica deverão contar com serviços de psicologia e de serviço social para atender as necessidades e prioridades definidas pelas políticas de educação, por meio de equipes multiprofissionais.

A determinação está prevista na Lei 13.935/2019, promulgada pelo governo federal e publicada no Diário Oficial da União (DOU), as equipes multiprofissionais deverão desenvolver ações para a melhoria da qualidade do processo de ensino-aprendizagem, com a participação da comunidade escolar, atuando na mediação das relações sociais e institucionais. 0 trabalho deverá considerar o projeto político-pedagógico das redes públicas de educação básica e dos seus estabelecimentos de ensino. Embora exista a Lei, Petroni e Souza (2017) salientam que apesar de haver psicólogos atuando nas redes de ensino, ainda há prejuízos no que diz respeito às suas ações, pois o número de profissionais inseridos nesse campo não atende às demandas que emergem desses contextos. Porém, ao mesmo tempo, essas atribuições revelam avanços, na 
medida em que oferecem margem para se propor ações que transponham essa delimitação, sobretudo junto aos professores e, ainda, na ideia de parceria com os profissionais e na menção a atuar "nas relações".

Para Souza et al. (2019) destacam que a Psicologia Escolar e Educacional não desiste de ampliar sua presença, tão necessária para aqueles que constroem o dia-a-dia escolar, as práticas formativas, que defendem valores humanos, que buscam garantir direitos sociais e que se propõem a diminuir as desigualdades e a discriminação na sociedade e na escola. Continuamos na luta: por uma sociedade mais justa, por uma escola de qualidade social, por um desenvolvimento humano enraizado em valores que promovam a ética, a participação e o engajamento social.

Ramos et al. (2020) menciona que em doenças não graves, a psicoterapia é o tratamento adequado, visto que o componente psicológico é prioritário. Às vezes, o uso de um ansiolítico ou antidepressivo pode promover a serenidade necessária para poder fazer uma psicoterapia eficaz ou para que a própria pessoa possa empregar seus recursos pessoais e sair da situação de conflito. Mesmo assim, a psicoterapia é a forma de tomar consciência da origem do seu desconforto. Mas nem sempre a atenção pública à saúde mental consegue oferecer um serviço de psicoterapia à disposição de todos, por isso o uso de medicamentos é mais caro. Nas doenças mais graves, a concomitância de tratamentos psicoterapêuticos e medicamentosos com uma abordagem social é essencial para o alcance de resultados terapêuticos satisfatórios. Segundo Telles e Pimenta (2009) a psicoterapia pode ser grupal quando o tratamento é realizado a um grupo de pacientes. As psicoterapias podem ter objetivos e métodos diferentes, mas em todos os casos o instrumento de trabalho é a palavra. A maioria dos profissionais de saúde mental pratica um dos seis tipos de psicoterapia, terapia comportamental, terapia cognitiva, terapia interpessoal, psicoterapia psicodinâmica, psicoterapia de apoio

Ainda de acordo com os autores Telles e Pimenta (2009) a terapia comportamental envolve uma série de intervenções que visam ajudar o sujeito a desaprender comportamentos desadaptativos enquanto aprende outros que são adaptados. A terapia de exposição, frequentemente usada para tratar fobias, é um exemplo de terapia comportamental. Na terapia de exposição, a pessoa é exposta a objetos, atividades ou situações temidas em um ambiente seguro. 0 objetivo é reduzir o medo e ajudar as pessoas afetadas a parar de evitar o que temem. A terapia comportamental está relacionada à terapia cognitiva. Em alguns casos, uma combinação de ambos é usada, conhecida como terapia cognitivo-comportamental. A base teórica da terapia comportamental é a teoria do aprendizado, segundo a qual os distúrbios comportamentais são consequência do aprendizado incorreto.

A terapia cognitiva ajuda a pessoa a identificar possíveis distorções nos pensamentos e a entender como essas distorções criam problemas em sua vida. Por exemplo, a pessoa pode pensar de uma maneira "tudo ou nada" ("se eu não for totalmente bem-sucedido, sou um fracasso total"). Salientado por Telles e Pimenta (2009), onde a premissa do trabalho utilizado estabelece que a maneira como uma pessoa se sente e se comporta é determinada pela maneira como ela interpreta suas experiências anteriores. Por meio da identificação de suas crenças e pressupostos fundamentais, a pessoa pode aprender outras formas de analisar suas experiências, conseguindo uma diminuição na intensidade dos sintomas e uma melhora no comportamento e na percepção de seus sentimentos.

A terapia interpessoal foi inicialmente concebida como um tratamento psicológico breve para a depressão e foi projetada para melhorar a qualidade das relações interpessoais no sujeito deprimido. A psicoterapia psicodinâmica, semelhante à psicanálise, concentra-se na identificação de padrões inconscientes nos pensamentos, sentimentos e padrões de comportamento do sujeito. Nessa modalidade terapêutica, entretanto, a frequência das sessões varia de 1 a 3 vezes por semana, geralmente o sujeito permanecendo sentado e não deitado no divã. Além disso, menos ênfase é colocada na relação entre o sujeito e o terapeuta (TELLES; PIMENTA, 2009).

Conforme os autores Telles e Pimenta (2009) a psicoterapia de apoio, a mais frequentemente utilizada, baseia-se no estabelecimento de uma relação empática e de apoio entre o sujeito e o terapeuta. Esse tipo de relacionamento estimula a expressão de sentimentos por parte do sujeito para que o terapeuta possa auxiliar na resolução de seus problemas. A psicoterapia focada no problema, uma forma de terapia de apoio, pode ser realizada com eficácia por médicos de atenção primária. 


\section{Atividades de prevenção}

Nos estudos de Polonial (2015) comenta que os avanços científicos em questões relacionadas à saúde abriram as portas para a gestão, prevenção e tratamento de várias doenças; dando a cura para patologias físicas que ainda não se conhecia. Este conhecimento abriu as portas para um modelo de gestão da saúde física, onde primariamente não curar a doença, mas sim preveni-la, para a promoção da saúde integral. Em desconformidade Rocha (2015) ressalta que o manejo dos transtornos e suas respectivas consequências é um processo longo e complexo, pois em muitos países, a saúde mental não é considerada uma prioridade, especialmente no que concerne aos professores que, como dito anteriormente, ficam à mercê de um sistema público de saúde. Ao contrário, em alguns deles, o atendimento a um psicólogo ou psiquiatra pode ser estigmatizado. Embora implantado esse modelo de prevenção e promoção da saúde mental o caminho é longo e apresenta muitas dificuldades para uma execução correta.

Moreira (2015) descreve a implementação da promoção da saúde integral à criação de condições sociais, individuais e ambientais que permitem o desenvolvimento psicofisiológico para melhorar a vida das pessoas. Por outro lado, a prevenção em saúde mental visa minimizar os fatores de risco e consolidar fatores protetores úteis ao longo da vida dos professores. Com isso, processos que contribuem para o desenvolvimento ou agravamento da doença mental podem ser modificados. Salientado por Diehl (2016) que a utilização desse modelo, pode-se auxiliar no funcionamento adequado nas atividades da vida diária. Além disso, serve de suporte para que as pessoas sejam treinadas para resolver e se manterem livres de problemas cognitivos, comportamentais e emocionais que podem afetar seu funcionamento geral.

Tostes et al. (2018) aponta que o aspecto que pode ter mais impacto na melhoria da saúde mental dos professores é a promoção de um bom ambiente de trabalho em que os profissionais da educação se sintam "ouvidos e apoiados". Desta forma, o trabalho em grupo, a criação de grupos de mútua ajuda entre colegas e a promoção de atividades recreativas são elementos que não requerem grandes recursos, mas que podem afetar diretamente uma melhor saúde mental de quem se dedica à docência. Enfatizado por Moreira (2015) que a prevenção passa necessariamente por uma avaliação constante dos riscos, constante porque é um elemento dinâmico que deve ser revisto e atualizado e, portanto, requer revisões periódicas.

\section{CONSIDERAÇÕES FINAIS}

O sistema educacional parece ter uma falha que poucos estão dispostos a aceitar. Se acrescentarmos a isso o fato de os professores terem sido chamados a serem os depositários do que se passou a chamar de "pedagogia da paz", o quadro não parece animador. Os fatores de risco psíquico associados ao trabalho docente são muitos.

O fantasma da doença mental assombra as salas de aula de milhares de professores. Os estudos ora apresentados mostraram que muitos professores sofrem de ansiedade, medo, angústia, entre outros problemas, que não se enquadram na lógica dos tratamentos, que se recusam a desabilitar por problemas psicológico e que retarda a possibilidade de encaminhar para um especialista a quem consulta por estes motivos.

Embora muitos queiram ignorar, hoje se trava uma batalha nas escolas públicas do país com a ideia de sofrer de transtornos classificados como "personalidade". Os professores, encarregados de orientar milhões de crianças e jovens, estão exaustos e sentem que a responsabilidade não pode ser exclusiva deles. Eles se perguntam por que o Estado e a família não assumem sua cota em uma situação que já foi objeto de denúncias e investigações, como mostram os estudos.

Os fatores de risco psicológicos associados ao trabalho docente são muitos. Embora esse trabalho seja considerado uma atividade sem risco aparente, as repetidas consultas para pescoço, costas, gastrite, hipertensão e dores nas costas por estresse são muito frequentes.

Nos estudos coletados, verifica-se um desconforto psicossocial que ninguém está tratando. A saúde mental não é mencionada em nenhum Ministério da Educação, nem nos discursos dos sucessivos ministros do ramo. Parece que em um país violento, com profundas desigualdades sociais, com polarizações brutais, entre tantas outras, evitamos reconhecer que não temos sido capazes de atender a necessidades intangíveis que já estão cobrando seu preço.

O estado psicofísico de quase metade dos professores analisados nos estudos da revisão e sua insatisfação com o trabalho são variáveis que afetam a motivação e, portanto, também a capacidade e eficácia educacional dos professores. Esses são dois fatores que merecem uma abordagem mais sistemática, 
levando em consideração os problemas de qualidade educacional que o Brasil apresenta. Até o momento, as políticas educacionais não mostraram sensibilidade para enfrentar esse problema.

O estado patológico próprio do meio social se transforma, simbolicamente, em uma patologia interna, que abre uma perspectiva de ação para os indivíduos afetados: quando eles não conseguem transformar o meio ambiente, pelo menos podem lidar com sua doença. É uma reação sócio politicamente ineficaz, mas que gera sentido subjetivo. No entanto, os transtornos psicofísicos agravam ainda mais os problemas que os professores enfrentam em todos os níveis de suas vidas profissionais.

Constatou-se que os psicólogos podem fornecer orientações e encaminhar os professores para as devidas intervenções, no entanto, este ainda é uma questão ainda pouco debatida nos Estados, uma vez que apesar da existência de lei, há poucos profissionais atuando nas escolas e, quando existem, fazem o trabalho apenas com os alunos. Assim, é relevante estimular a conscientização na identificação de manifestações da saúde mental dos professores e, acima de tudo, para preveni-las. Eles também podem contribuir para a expansão de serviços de aconselhamento confidenciais e de livre acesso. Além desses enfoques nas políticas públicas, a profissão também tem uma dimensão pedagógica, na medida em que se trabalha numa perspectiva de transformação da consciência dos sujeitos, com vistas à sua emancipação. Junto aos professores que sofrem sequelas em sua saúde mental, devemos empreender um trabalho incansável na perspectiva do resgate desses profissionais como sujeitos de direitos, como seres sociais e como cidadãos.

Importante se faz apontar que a pesquisa bibliográfica sobre a saúde mental dos professores em Manaus é difícil. Aos poucos estudos realizados, soma-se a variável qualidade metodológica dos mesmos e a escassa publicação em periódicos científicos. Sendo assim, sugere-se que mais estudos sejam realizados com a temática ora apresentada, servindo este estudo como ponto de partida.

\section{REFERÊNCIAS}

[1] ABRAPEE. Associação Brasileira de Psicologia Educacional e Escolar. Disponível em: https://abrapee.wordpress.com/. Acesso em: 01. out. 2020.

[2] ANDRADA, P. C. et al. Atuação de Psicólogas(os) na Escola: Enfrentando Desafios na Proposição de Práticas Críticas. Psicologia: Ciência e Profissão v. 39, n. 3, p. 1-16, 2019.

[3] CFP - Conselho Federal de Psicologia - Resolução no 02/01. ANEXO I -Definição das especialidades a serem concedidas pelo conselho federal de psicologia, para efeito de concessão e registro do título profissional de especialista em psicologia. 2001. Disponível em http://site.cfp.org.br/resolucoes/resolucao-n-2-2001/ Acesso em: 30 set. 2020.

[4] DIEHL, Liciane; MARIN, Angela Helena. Adoecimento mental em professores brasileiros: revisão sistemática da literatura. Est. Inter. Psicol., Londrina, v. 7, n. 2, p. 64-85, dez. 2016.

[5] ESTEVE, J. La salud mental de los profesores y sus relaciones con las condiciones de trabajo. Málaga: Paidós, 2017.

[6] FERREIRA, A. S. Intervenção psicopedagógica numa perspectiva multidisciplinar. Brasília: Conselho Federal de Psicologia, 2015.

[7] FERLA, Alcindo Antônio et. al. Pesquisando no cotidiano do trabalho na saúde: aspectos metodológicos e de formatação para elaboração de projetos de informação científica e tecnológica em saúde. Porto Alegre: Grupo Hospitalar Conceição, 2008.

[8] FRANÇA, Ana Cristina Limongi, RODRIGUES, Avelino Luiz. Stress e Trabalho. 12.ed. São Paulo, Atlas, 2012.

[9] GASPARINI, Sandra Maria; BARRETO, Sandhi Maria; ASSUNCAO, Ada Ávila. Prevalência de transtornos mentais comuns em professores da rede municipal de Belo Horizonte, Minas Gerais, Brasil. Cad. Saúde Pública, Rio de Janeiro, v. 22, n. 12, p. 2679-2691, Dec. 2016.

[10] GOUVÊA, L. As condições de trabalho e o adoecimento de professores na agenda de uma entidade syndical. Saúde Debate, v. 40, n. 111, p. 206-219, 2016.

[11] HELOANI, José Roberto; CAPITAO, Cláudio Garcia. Saúde mental e psicologia do trabalho. São Paulo Perspec., São Paulo, v. 17, n. 2, p. 102-108, June, 2003.

[12] HERCULANO, R. C. (Org.). Formação em Psicologia Escolar: realidades e perspectivas. Campinas, SP: Editora Alínea, 2017. 
[13] LIMA, P. F. DE S. Atuação do psicólogo escolar/educacional em um programa de orientação profissional de um cursinho pré-vestibular gratuito. In: Resumos da XI Reunião Anual da Sociedade de Psicologia do Triângulo Mineiro. Uberlândia: SPTM, 2015.

[14] LIMA, T. C. S; MIOTO, R. C. T. Procedimentos metodológicos na construção do conhecimento científico: a pesquisa bibliográfica. Rev. Katál Florianópolis, v.10, 2007.

[15] LOURENÇO, V. R. et al. A docência e o cotidiano da escola pública: influências na saúde mental do professor. Research, Society and Development, v. 9, n. 8, 2020.

[16] MARTINS, A. B., A. O psicólogo na construção da proposta pedagógica da escola: áreas de atuação e desafios para a formação. In: ALMEIDA, S. F. C. de (Org.). Psicologia Escolar: ética e competências na formação e atuação profissional. Campinas: Editora Alínea, 3.ed 2019.

[17] MOREIRA, A. S. G. Qualidade de Vida dos professores do Ensino Fundamental de uma escola da rede pública. TCC (Graduação)- Departamento de Fisioterapia, Centro de Ciências Biológicas e da Saúde, Universidade Estadual da Paraíba, Campina Grande, 2015.

[18] NOVAES, M. H. Psicologia escolar. Rio de Janeiro: Vozes, 2019.

[19] PETRONI, A. P.; SOUZA, V. L. Psicologia Escolar: análise sobre dificuldades e superações no Brasil e Portugal. Psicologia Escolar e Educacional, SP. v. 21, n. 1, J, p. 13-20, 2017.

[20] PENTEADO RZ, NETO SS. Mal-estar, sofrimento e adoecimento do professor: de narrativas do trabalho e da cultura docente à docência como profissão. Saúde e Sociedade, v. 11, n. 1, p. 1-14, 2019.

[21] POLONIAL, J. A saúde do professor no contexto das transformações recentes no mundo do trabalho.. Tese (Doutorado)- Programa de Pós-Graduação em Sociologia, Faculdade de Ciências Sociais, Universidade de Goiás, Goiânia, 2015.

[22] RAMOS, L. S. et al. O ambiente escolar incapaz de assegurar a saúde mental do professor: uma revisão literária. REAS/EJCH. vol.Sup.n.49, 2020.

[23] RAMOS, M.Z.; TITTONI J, NARDI HC. A experiência de afastamento do trabalho por adoecimento vivenciada como processo de ruptura ou continuidade nos modos de viver. Cadernos de Psicologia Social e do Trabalho. v. 11, n. 2, p. 209-221, 2008.

[24] ROCHA, M. L. da (Orgs.). Psicologia e Educação: desafios teórico-práticos. São Paulo: Casa do Psicólogo, 2015.

[25] SATO, Leny; LACAZ, Francisco Antonio de Castro; BERNARDO, Márcia Hespanhol. Psicologia e saúde do trabalhador: práticas e investigações na Saúde Pública de São Paulo. Estud. psicol. (Natal), Natal, v. 11, n. 3, p. 281-288, 2006.

[26] SCHAUFELI, WB 0 futuro da psicologia da saúde no trabalho. Psicologia aplicada: uma revisão internacional, v. 53, n. 4, p. 502-517, 2014.

[27] SCHMIDT, B. et al. Saúde mental e intervenções psicológicas diante da pandemia do novo coronavírus (COVID-19). Estud. psicol. (Campinas), Campinas, v. 37, n. 3, p. 28-35, 2020.

[28] SILVA, F. C.; SIMONETTO, K. Análise de produções científicas sobre a saúde mental do professor na educação. Pedagog. Foco, Iturama (MG), v. 11, n. 5, p. 95-108, jan./jun. 2016.

[29] SOUZA, A.N; LEITE, M.P. Condições de trabalho e suas repercussões na saúde dos professores da educação básica no Brasil. Educação \& Sociedade, v. 117, n. 32, p. 1105-1121, 2011.

[30] SOUZA, M. P. R. A atuação do psicólogo na rede pública de educação: concepções, práticas e desafios. Tese de Livre Docência, Departamento de Psicologia da Aprendizagem, do Desenvolvimento e da Personalidade, Instituto de Psicologia, Universidade de São Paulo. São Paulo, SP, 2015.

[31] SOUZA, M. P. R. et al. O compromisso Ético-Político da Psicologia Escolar e Educacional. Psicol. Esc. Educ., Maringá, v. 23, n. 3, p. 12-19, 2019.

[32] TELLES, S. H.; PIMENTA, A. M. C. Síndrome de burnout em ACS e estratégias de enfrentamento. Saúde e Sociedade, São Paulo, v. 18, n. 3, p. 467-478, 2009.

[33] TORRES, A.R. et al. 0 adoecimento no trabalho: repercussões na vida do trabalhador e de sua família. SANARE-Rev. Políticas Públicas. v. 10, n. 1, p. 10-23, 2013. 
[34] TOSTES, M. V. et al. Sofrimento mental de professores do ensino público. Saúde debate, Rio de Janeiro, v. 42, n. 116, p. 87-99, Jan. 2018.

[35] VIAPIANA, V. et al. Adoecimento psíquico na sociedade contemporânea: notas conceituais da teoria da determinação social do processo saúde-doença. SAÚDE DEBATE. v. 42, n. 4, p. 175-186, 2018.

[36] VIVES, V. El movimiento pedagógico del colegio de profesores como uma recuperación del rol docente y de la autoestima professional. Dissertação. (Ciências da Educação) - Facultad de Ciencias Sociales, Santiago de Chile, 2015. 


\section{Capítulo 10}

\section{Arteterapia na esquizofrenia um estudo de caso}

\section{Daynara Souza Aparício}

Resumo: 0 presente trabalho apresenta a arteterapia como alternativa para tratamento de uma paciente com esquizofrenia, que recentemente aderiu a esse tipo de tratamento em conjunto com a terapia medicamentosa e o anseio da família em ajudar a paciente em casa. A arte como terapia dentro do contexto da esquizofrenia tem como objetivo o expressar da subjetividade de seu usuário, bem como por meio de reflexão em torno da singularidade que a arte possibilita. Toda sua terapia artística foi direcionada para seu bem-estar psíquico e a diminuição da alucinação auditiva segundo dados coletados durante a observação participante. 0 objetivo da pesquisa é compreender o uso, da arteterapia no tratamento de esquizofrenia, bem como identificar as atividades arterapeuticas desenvolvidas em pacientes esquizofrênicos, identificar a percepção do paciente em relação às atividades de arteterapia e levantar a percepção do psicólogo em relação às atividades de arteterapia no tratamento da esquizofrenia. Para a coleta de dados foi utilizado à pesquisa tipo estudo de caso com uma abordagem qualitativa, com a técnica de observação participante que consiste em forma direta ou indiretamente a participação do pesquisador. Os resultados obtidos foram atestar que a intervenção arte terapêuticas favoreceu no controle das emoções e de alguns sintomas como alucinação auditiva e convívio social a terapêutica demonstra-se uma alternativa no tratamento da esquizofrenia. A arteterapia aqui descrito discute como sua utilização é essencial no tratamento da pessoa com esquizofrenia, no âmbito social, individual e terapêutico. Por fim apresenta-se o desenvolvimento da paciente no transcorrer de 3 meses.

Palavras-chave: Arteterapia; esquizofrenia; qualidade de vida. 


\section{INTRODUÇÃO}

O estudo em questão é desenvolvido, a partir da reunião de informações encontradas, descritas e analisadas do caso de uma paciente esquizofrênica que está sendo submetida a sessões de arteterapia. Buscou-se evidenciar a arte como terapia como uma alternativa para o tratamento de uma das condições psiquiátricas mais graves da atualidade e que se constitui como um problema de saúde pública, bem como fazer uma reflexão sobre a arte como instrumento terapêutico no campo específico da Psicologia.

A definição de arteterapia é controversa, visto que é ainda uma nova área do conhecimento. A terapia envolve duas palavras que se completam e se inter-relacionam muito bem que é Arte e Terapia. A partir destas duas palavras, podemos definir arteterapia como sendo o uso da arte dentro de um processo terapêutico. Por meio da expressão verbal e não verbal, estaremos trabalhando com diferentes formas de autoconhecimento, e, portanto, crescimento pessoal.

Hoje a arteterapia não está mais restrita aos consultórios, revelando-se um valioso instrumento para intervenções também nas áreas da Psicologia social, escolar, organizacional, da saúde e hospitalar. 0 que se quer mostrar aqui é que a arte é um poderoso canal de expressão da subjetividade humana, que permite ao psicólogo e a seu cliente, seja individual ou grupo, acessar conteúdos emocionais e reconstruílos por meio da própria atividade artística.

Para discutir de forma sistemática o assunto, elaborou-se como objetivo primário do trabalho, compreender o uso da arte no tratamento de esquizofrenia. Os objetivos específicos deste trabalho foram: a. identificar as atividades de arteterapia desenvolvidas em pacientes esquizofrênicos; b. identificar a percepção dos pacientes em relação às atividades de arteterapia; c. levantar a percepção do psicólogo em relação às atividades de arteterapia no tratamento de esquizofrenia.

A relevância social deste trabalho pode ser expressa pela influência na criação de mudanças e quebra de paradigmas socioculturais, pois favorece a reflexão sobre as formas como a sociedade tem lidado com as pessoas esquizofrênicas, propiciando um "repensar" de atitudes, ideias, preconceitos, mitos construídos.

\section{RERENCIAL TEÓRICO}

\section{A patologização da esquizofrenia}

Devido a necessidade de se classificar as psicopatologias, buscou-se formas e comparativos a fim de se estabelecer o normal e o patológico. Silva (2009) comenta que estabeleceu-se uma classificação de transtornos mentais pautada pelo modelo médico, com o intuito de apresentar a existência de doenças com etiologia, sintomologia, curso e resultados comuns. Entre essas classificações surgiu uma denominada demência precoce, visto que passava a se manifestar no início da vida e quase invariavelmente levava a problemas de ordem psíquica. Nessa patologia, dentre os principais sintomas observados pelo psiquiatra alemã estavam "alucinações, perturbações em atenção, compreensão e fluxo de pensamento, esvaziamento afetivo e sintomas catatônicos" (SILVA, 2009, p. 263). A etiologia da patologia era endógena, devido ao fato de que o transtorno surgia devido a causas internas.

A demência precoce só passou a ser empregada com o termo esquizofrenia pelo psiquiatra suíço Eugen Bleuer, o qual observou a "fragmentação do pensamento e das emoções durante os surtos agudos da demência precoce. Essa observação fez com que Bleuler substituísse o nome dessa condição por esquizofrenia, de "esquizo" cisão e "frenia" mente" (ALVES; SILVA, 2001, p. 13). Esquizofrenia em significado de etimologia contempla de tal forma, a cisão da mente.

Elkis (2000) apontou que foi somente em 1948 que Schneider abordou de modo inteiramente clínico a necessidade de identificar os sintomas característicos (Sintomas de Primeira Ordem - SPO) da esquizofrenia, os caracterizando na:

Sonorização dos próprios pensamentos, quando o indivíduo ouve os seus próprios pensamentos `soando alto; escutar vozes sob a forma de argumento e contra - argumento; Escutar comentários e vozes que acompanham a realização das próprias atividades; Vivenciar experiências de influência corporal; Experimentar roubo do pensamento e formas diversas de influência do pensamento; Sentir que tudo está sendo influenciado pelos outros no campo dos sentimentos, pulsões e vontade; Apresentar uma percepção delirante (ELKIS, 2000, p. 18). 
O DSM-5 (APA, 2014) elenca as características essenciais e os sintomas da esquizofrenia entendidos como: Delírios; Alucinações; Fala desorganizada (ex., descarrilamento frequente ou incoerência); Comportamento totalmente desorganizado ou catatônico; e Sintomas negativos, ou seja, embotamento afetivo, alogia ou avolição. Bleuer (1960, Apud AMARAL, 2014), também havia trabalhado os sintomas fundamentais, que muito ampliou os conhecimentos trazendo à luz algumas características importantes como: a. Presença de transtornos de associação extravagantes, demasiados ou em obstrução; b. Transtornos de afetividade, caracterizados pela indiferença; c, Predileção por fantasia; d. Ambivalência de vontade, afeto e intelectual; e e. Tendência a se distanciar da realidade.

Houve, no entanto, diferentes perspectivas e percepções dos pesquisadores quanto às concepções iniciais da esquizofrenia. De acordo com Oliveira (2010), essas foram apenas às abordagens iniciais envolvendo a descoberta da esquizofrenia, visto que a mesma sempre esteve presente na humanidade.

A esquizofrenia, uma das perturbações psiquiátricas mais graves, é reconhecida desde a antiguidade. As primeiras referências na literatura que descrevem as perturbações mentais semelhantes à esquizofrenia remontam ao tempo de Hipócrates (460-370 AC), permanecendo um conceito estagnado até os séculos XIX e XX quando os psiquiatras franceses e alemães poliram as suas impurezas. De facto, até o século XIX, a psicose era considerada uma mera forma de loucura e os psiquiatras, então referidos como alienistas, pouco respeitados na comunidade médica (OLIVEIRA, 2010, p. 7).

Alves e Silva (2001) caracterizam o transtorno esquizofrênico pela apresentação de distorções funcionais em graus variados e de modo simultâneo, com alterações no nível de motivação, estados afetivos e processos cognitivos. 0 conteúdo do pensamento dos indivíduos de esquizofrenia se apresenta de modo fragmentado, com perda de associações lógicas, expressões de modo incoerente, vago, circunstancial e repetitivo. Assim, para as autoras, a percepção também se encontra alterada, sendo o principal distúrbio perceptivo as alucinações auditivas, com a escuta das vozes quando o paciente está sozinho e quando não há ninguém perto. Alucinações visuais, olfativas ou táteis podem ocorrer, porém essas alterações são consideradas menos comuns.

Os indivíduos esquizofrênicos também podem ter ilusões (percepção de objetos reais de modo distorcido) ou despersonalização (sensação de que o seu corpo está sofrendo modificações). Também são observados distúrbios motores, tais como catatonia (alterações intensas da motricidade caracterizadas por imobilidade e comportamento indiferente ao ambiente), movimentos estereotipados (repetitivos e sem propósito), atividades motoras incontroláveis e agitação, sendo as duas últimas as mais frequentes. Em consequência dessas alterações, o indivíduo perde o senso de identidade pessoal, e tem extrema dificuldade de estabelecer contato social, ficando isolado em seus pensamentos e fantasias, ou ouvindo alucinações (ALVES; SILVA: 2001, p. 13).

Matos et al. (2014) apontam que os sintomas da esquizofrenia afetam toda a vida do paciente, nos aspectos afetivo, social, familiar e financeiro, dentre outros, além de mudar permanentemente o estilo de vida dos que estão mais próximos, por se tratar de uma doença crônica ainda sem cura. Para os autores, a esquizofrenia afeta diretamente a personalidade e o modo de agir do indivíduo. A patologia é considerada devastadora causando problemas relacionais e laborais para o indivíduo. Além disso, ainda existe o preconceito da sociedade.

\section{Arteterapia}

Para Philipinni (2008) existem inúmeras possibilidades de conceituar arteterapia, uma delas é considerála como um processo terapêutico decorrente da utilização de modalidades expressivas diversas, que servem a materialização de símbolos. A arteterapia é definida pela Sociedade Portuguesa de Arteterapia (SPAT) como um método de tratamento terapêutico para o desenvolvimento pessoal, que faz uso e integra diferentes mediadores artísticos (MARTINS, 2012).

Reis (2014) fala que entre os anos 20 e 30, as teorias de Freud e Jung trouxeram as bases para o desenvolvimento inicial da arteterapia como campo especifico de atuação. 0 mesmo autor afirma que

A ideia freudiana de que o inconsciente se expressa por imagens, tais como as originadas no sonho, levou à compreensão das imagens criadas na arte como 
uma via de acesso privilegiada ao inconsciente, pois elas escapariam mais facilmente da censura do que as palavras. Apesar desse grande achado, o próprio Freud não chegou a utilizar a arte como parte do processo psicoterapêutico (REIS, 2014 p.4).

Jung foi quem começou a utilizar a linguagem artística associada à psicoterapia (REIS, 2014). Diferentemente de Freud, que considerava a arte uma forma de sublimação das pulsões, Jung considerava a criatividade artística uma função psíquica natural e estruturante, cuja capacidade de cura estava em dar forma, em transformar conteúdos inconscientes em imagens simbólicas (SILVEIRA, 2001 Apud REIS, 2014).

Jung utilizava o desenho livre para facilitar a interação verbal com o paciente e porque acreditava "na possibilidade de o homem organizar seu caos interior utilizando-se da arte" (ANDRADE, 2000 Apud REIS, 2014).

A partir dessas duas vertentes, a arte como instrumento terapêutico ganha progressivamente espaço. Vale citar que, Margareth Naumburg ${ }^{1}$, foi fundadora da arteterapia, pois foi a primeira a sistematiza-la no de 1941. Com o trabalho denominado Arteterapia de Orientação Dinâmica tendo como base de desenvolvimento a teoria psicanalítica.

Reis (2014) considera que no Brasil, a história da arteterapia nasce na primeira metade do século passado entrelaçada com a psiquiatria e influenciada tanto pela vertente psicanalítica quanto pela junguiana. Com seus percursores Osório Cesar e Nise da Silveira, ambos com trabalhos com arte em instituições de saúde mental.

Embora os psiquiatras Osório César e Nise da Silveira sejam pioneiros no trabalho com terapias expressivas no Brasil, o desenvolvimento da arteterapia e sua sistematização no campo específico da Psicologia se deram posteriormente (REIS, 2014).

Assim descreve,

Na construção desse campo, destaca-se Maria Margarida M. J. de Carvalho, que, em 1980, implantou o primeiro Curso de Arteterapia no Instituto Sedes Sapientae, em São Paulo. Ela é psicóloga clínica, foi professora do Instituto de Psicologia da USP e coordenadora, em 1995, do livro A Arte Cura? Recursos Artísticos em Psicoterapia. Outro marco destacado por Andrade foi à criação, em 1982, da Clínica Pomar, no Rio de Janeiro, coordenada por Angela Philippini, onde se oferece curso de formação em arteterapia de orientação junguiana. Já em 121990, outra abordagem entra no cenário da arteterapia brasileira, ao ser implantada uma especialização em arteterapia gestáltica por Selma Ciornai, nas Sedes Sapientae. Desde então, a arteterapia vem crescendo cada vez mais, ganhando outros espaços além da clínica e também outras molduras teóricas, como a rogeriana, a antroposófica e a transpessoal, entre outras. (ANDRADE, 2000 Apud REIS 2014 p.14)

De acordo com Martins (2012), o fazer artístico é visto como uma experiência que oferece a oportunidade de expressa com imaginação, autenticamente e espontaneamente. Um processo que, ao longo do tempo, leva a realização pessoal, reparação emocional e transformação a nível psíquico.

\section{0 uso da arteterapia no tratamento da esquizofrenia}

Ruddy e Milnes (2005) ressaltam que ao longo das últimas décadas foram produzidos muitos estudos em âmbito internacional que buscaram quantificar e representar o efeito das abordagens em arteterapia para as pessoas com esquizofrenia, entretanto, os autores verificaram que, de modo geral, tais estudos são pouco abrangentes, não contemplando especificamente nas possibilidades de uso da arteterapia como um dispositivo terapêutico no âmbito da esquizofrenia.

Patterson et al. (2011) apontaram em seu estudo que as recomendações primordiais no âmbito do tratamento das pessoas com esquizofrenia apontam para a necessidade de consideração de terapias

12 . Na perspectiva de Naumburg, as técnicas de arteterapia visam a facilitar a projeção de conflitos inconscientes em representações pictóricas, sendo esse material submetido à interpretação seguindo o modelo teórico proposto por Freud. 
artísticas como a arteterapia. Os autores defendem que, embora a arteterapia esteja intrinsecamente ligada à "psicose" e tenha aporte clínico, os responsáveis pela implantação de sua orientação, desenvolvimento e acompanhamento precisam saber mais sobre a terapia, especificamente no que muda na condição da pessoa com esquizofrenia e com quais objetivos a arteterapia deve ser articulada.

Na obra de Nise da Silveira intitulada 'Imagens do Inconsciente` estabeleceu que a imaginação material a partir do estudo de argila, da tinta, da madeira e de outras texturas e densidades proporcionariam efeito na criatividade das pessoas, assim como outras substâncias como o fogo e a água também podem estimular a criatividade e imaginação dos indivíduos (SILVEIRA, 1981). Nesse sentido, os indivíduos submetidos aos trabalhos realizados com a arteterapia poderiam ser amplamente beneficiados por sua prática no âmbito do tratamento da esquizofrenia.

Vasconcelos (2000) alegam que no âmbito da saúde mental, a arte pode ser utilizada como terapia dando mais liberdade e iniciativa para os pacientes psicóticos. Nesse sentido, o empoderamento (empowerment) é uma das prerrogativas do trabalho de arteterapia com os pacientes com esquizofrenia, sobretudo devido ao fato de que tais pacientes são conferidos ao poder de manipular e desenvolver suas criações.

Segundo Rotelli et al. (2001), a arteterapia desponta como uma possibilidade de aprofundar a reforma psiquiátrica no sentido da desinstitucionalização, possibilitando diversos modos de expressão, de modo que a arte não deve ser concebida como uma ocupação de tempo, mas sim como um dispositivo terapêutico e com o reconhecimento de um direito do paciente. Nesse sentido, os autores apontam que as abordagens arteterapêuticas devem ser contempladas no âmbito da autonomia do paciente, visto que a instituição e o profissional não devem a compreender tão somente como uma técnica de tratamento, mas como uma prática capaz de produzir amplos benefícios para os pacientes.

Sob outra perspectiva, estão às afirmações de Vasconcelos (2000) e de Rotelli et al. (2001), verifica-se um ponto de encontro entre tais assertivas, contemplando a arteterapia como uma prática que detém finalidades que vão além do tratamento da esquizofrenia, mas que são amplamente viabilizadas nesse sentido. Com isso, os profissionais envolvidos nesse processo devem propiciar o empoderamento dos pacientes, realizando o acompanhamento dos mesmos, mas sem dar ordens, tornando a arteterapia uma prática flexível e dinâmica.

Mella et al. (2011) também aprofundaram as questões envolvendo o insight e o autoconhecimento como um todo no âmbito da esquizofrenia, considerando que do ponto de vista conceitual, tais elementos envolvem a interação dos seus componentes com diferentes domínios sintomatológicos da esquizofrenia e as condições relacionadas com os aspectos subjetivos e culturais do paciente. $\mathrm{O}$ autoconhecimento, assim, se revela como uma tarefa complexa, porém possível e necessária no âmbito do tratamento da esquizofrenia.

Estima-se que a arteterapia possa se configurar como um instrumento importante na expressão da subjetividade dos usuários e, com isso, auxiliar no tratamento da esquizofrenia; por meio da reflexão em torno da singularidade que a arte possibilita. Esta reflexão pode auxiliar no traquejo com a realidade e a expressão das frustrações antes canalizadas nos delírios, agora exploradas nos trabalhos. (FONSECA et al., 2014, p. 3).

A utilização da arteterapia como um dispositivo terapêutico abrange o ideário que contempla a arte como uma possibilidade de libertar o paciente com esquizofrenia não tão somente da exclusão, mas também da alienação provocada pela psicose. A partir da percepção criativa, o paciente sente que a vida é digna de ser vivida, sem provocar o relacionamento de submissão do indivíduo com a realidade externa, de modo a assumir "um sentido de profilático na criação de estratégias para uma melhoria na qualidade de vida dos pacientes" (FONSECA et al., 2014 p.3).

\section{PROCEDIMENTOS METODOLÓGICOS}

A pesquisa realizada foi um estudo de caso. 0 estudo de caso possui uma metodologia de pesquisa classificada como aplicada, na qual se utiliza a prática de conhecimentos para a solução de problemas sociais (BOAVENTURA, 2004). Gil (2008) complementa que, as pesquisas com esse tipo de natureza estão voltadas mais para a aplicação imediata de conhecimentos em uma realidade circunstancial, relevando o desenvolvimento de teorias.

Para Prodanov e Freitas (2013) o estudo de caso consiste em coletar e analisar informações sobre determinado indivíduo, uma família, um grupo ou uma comunidade, a fim de estudar aspectos variados de 
sua vida, de acordo com o assunto da pesquisa. É um tipo de pesquisa qualitativa, entendido como uma categoria de investigação que tem como objeto o estudo de uma unidade de forma aprofundada, podendo tratar-se de um sujeito, de um grupo de pessoas, de uma comunidade etc. São necessários alguns requisitos básicos para sua realização, entre os quais, severidade, objetivação, originalidade e coerência. .

Como método, escolheu-se o estudo de caso, o qual se refere a um trabalho minucioso e profundo de um ou mais objetos (YIN, 2001). Pode permitir novas descobertas de aspectos que não foram previstos inicialmente. De acordo com Yin (2001), a essência do estudo de caso é tentar esclarecer uma decisão, ou um conjunto de decisões, seus motivos, implementações e resultados.

Para alcançar os objetivos propostos, o instrumento de pesquisa utilizada foi observação participante que assim define Minayo (2001) como um processo pelo qual se mantém a presença do observador numa situação social, com a finalidade de realizar uma investigação cientifica. Desse modo, o observador estará em convivência com os observados ao participar de suas vidas, de seu cenário cultural e assim colhe os dados que necessita. 0 observador é a parte do contexto sob observação ao mesmo tempo modificado e sendo modificado por este contexto.

Também foram realizados os registros das observações coletadas em forma de relatórios, após a coleta de dados houve organização dos mesmos para posterior análise e interpretação culminadas nos resultados.

Prodanov e Freitas (2013) salientam que observação participante consiste na participação real do conhecimento na vida da comunidade, do grupo ou de uma situação determinada.

A análise utilizada nesta pesquisa foi à análise de conteúdo, conforme evidenciado por Minayo (2013). De acordo com a autora, a análise de conteúdo trata-se de um conjunto de técnicas de análise das comunicações, cujo objetivo é a obtenção de indicadores que possibilitem no conteúdo a ser analisado, a inferência de conhecimentos referentes às condições de produção e recepção do referido conteúdo, fazendo uso de procedimentos sistemáticos e objetivos de descrição do conteúdo.

Quanto às etapas inerentes à Análise de Conteúdo, Minayo (2013) classifica em três etapas, a primeira préanálise, que consiste na escolha de documentos que formarão o núcleo a ser analisado e é decomposta de leitura flutuante, constituição de corpus, formulação e reformulação de hipótese e objetivos. Para realizar, pode-se mencionar as observações livres, as entrevistas, os questionários; a segunda etapa constitui-se na exploração do material, que engloba os processos de codificação e categorização, formando categorias temáticas adequadas ao tipo de análise que irá realizar; e a terceira etapa corresponde ao tratamento dos resultados, inferência e interpretação, ou seja, é a fase da reflexão, da intuição através de embasamento nos matérias empíricos, onde o conhecimento acumulado é debatido com o conhecimento adquirido.

A pesquisa seguiu os princípios fundamentais de respeito à dignidade humana e pela proteção primordial aos participantes das pesquisas científicas, envolvendo seres humanos, considerando o desenvolvimento e o engajamento ético, que é inerente ao progresso científico e tecnológico. Para esta pesquisa o participante terá um nome fictício de Luiza, preservando sua identidade e garantindo o anonimato das pessoas envolvidas e do participante.

Esta pesquisa contou com a participação de um (1) psicólogo (a) que utiliza arteterapia como técnica em pacientes esquizofrênicos e um (1) paciente que realiza essas atividades, as observações ocorreram num período de 3 meses (julho, agosto e setembro de 2020) na casa da paciente e fora no parque público.

Somente participaram da pesquisa um profissional graduado em Psicologia e que utiliza arteterapia como técnica e um paciente esquizofrênico que realiza as atividades. Após a assinatura do Termo de Consentimento Livre Esclarecido (TCLE) pela participante.

\section{RESULTADOS E DISCUSSÃO}

\section{Apresentação do caso}

Luiza tem diagnóstico de Esquizofrenia paranóide (CID F20. 0) desde seus 29 anos de idade, o primeiro surto aconteceu dois anos após o nascimento de seu segundo filho, desde então faz tratamento há 22 anos. Em 2008 teve uma internação no centro Psiquiátrico Eduardo Ribeiro, onde desde está internação começou seu tratamento no Centro de Atenção Psicossocial (CAPS), de 2011 até o momento não teve crise, porém ainda tem alucinações auditivas todos os dias. 
As vozes que ela escuta, define ser do bem e do mal, no entanto, as vozes do mal, são mais frequentes. Segundo ela as alucinações auditivas do mal a insulta, fala mal, fala palavrões e manda matar sua família e a si mesmo, porém consegue ter controle dessas alucinações quando faz uma oração.

Atualmente a paciente faz uso do fármaco Clozapina para remissão parcial dos sintomas, para auxiliar a medicação fez a procura por atividades artísticas e para que a ajude a ter mais o controle das vozes e que também ocupe seu cotidiano para que não fique somente em casa. Entre suas atividades a que se destaca é a arteterapia, que segundo ela tem lhe ajudado bastante em lidar com as alucinações auditivas e no bemestar emocional.

As sessões ocorrem semanalmente com auxílio de uma psicóloga, que intervém de forma indireta, através da atividade e dos materiais sugeridos, ou colocados à disposição. No processo arteterapêutico a psicóloga parte da premissa de que todos os indivíduos possuem preservada a sua capacidade criativa mesmo que uns achem mais fácil acessá-la do que outros e esta capacidade é parte do núcleo saudável de que tanto falamos.

A possibilidade de construir formas aos conteúdos inconscientes é parte fundamental do tratamento psicótico, pois desta forma ele tem a oportunidade de tornar as imagens arquetípicas que costumam dominar a sua consciência mais leves e de, assim, fazer contato com a realidade, saindo ainda que temporariamente do estado permanente de imersão no seu inconsciente.

Sendo desta maneira que Luiza consegue ter mais domínio de suas alucinações auditivas, conseguindo assim ter uma qualidade de vida, convivendo em harmonia com sua família e o meio social em que convive. Aprendendo também quais suas limitações.

\section{Descrição das sessões}

Para realização da pesquisa foram realizadas 16 sessões de intervenção arteterapêuticas com as modalidades de desenho, pintura com lápis de cor, colagem com mosaico e modelagem. As atividades foram realizadas 3 (três) vezes na semana com um paciente esquizofrênico sob a supervisão do psicólogo. Aqui a paciente usará o nome fictício de Luiza para preservação de sua identidade.

\section{Desenho livre}

As atividades iniciais foram com os desenhos e teve duração de 3 sessões. Para os desenhos livres era oferecido folha branca, lápis e lápis de cor. Inicialmente Luiza escuta as orientações que é passada sobre a atividade e demora alguns segundos para pegar o lápis e a folha de papel.

A paciente começa a desenhar uma casa, apresenta alguns sorrisos e parecia estar concentrada desenhando (como estivesse em outro lugar). Mal respondia a algumas indagações do terapeuta. Não gostava do lápis de cor, preferia lápis preto. Durante as sessões sempre demonstrava um leve sorriso, olhava para os lados e voltava a desenhar, tinha dias que estava um pouco agitada. Mas quando via os papéis e o lápis dirigia-se para mesa e se tranquilizava, nesses dias costumava-se rabiscar silhuetas de pessoas. Os desenhos preferidos eram casa, paisagem, árvores, carro e às vezes pássaros.

\section{Pintura com lápis de cor}

As pinturas com lápis de cor também tiveram duração de 3 sessões, foram colocadas diversas folhas impressas com diferentes tipos de desenhos e os lápis foram colocados em uma bandeja. Luiza sempre ouve as orientações com bastante atenção. Sempre escolhe desenhos que representam ambiente familiar, como casa, quarto, jardim, garagem. Foi observado que gosta muito de usar as cores vermelho, verde e azul. Raramente usa cores claras como o amarelas. A paciente se mantém bem concentrada e tranquila durante a pintura, mas apresenta dificuldade em fazer pintura livre o que a deixa muito agitada. Nesses momentos acaba fazendo rabiscos (traços), com as cores vermelho, azul e verde.

\section{Modelagem}

As atividades de modelagem aconteceram em 5 sessões. 0 material utilizado foi à massa de modelar com diferentes cores, e um pouco de água. A modelagem foi com imaginação livre, o terapeuta sempre começa as sessões demonstrando como é o trabalho com a massa de modelar fazendo bonecos, imitações de vasos, 
flor etc. Luiza apresenta certo medo (como se fosse um nojo), em tocar nas massas de modelar. Demora muito tempo para conseguir tocá-las, precisa que o terapeuta faça repetidas vezes a modelagem com as massas, tanto as massas secas, quanto com massas molhadas.

Depois de algum tempo, Luiza começa aos pouquinhos a tocar nas massas. Em uma de suas atividades começou a trabalhar com massa da cor azul, inicia fazendo uma bolinha, em seguida, aperta no meio como se quisesse fazer uma tigela bem fina, depois a solta. Demora um pouco para escolher outra massinha, dessa vez escolhe a cor branca, tenta fazer alguns bonecos bem pequenos sem olhos e sem nariz e quando ficam prontos ela olha e sorri satisfeita com seu trabalho. Em três dessas sessões Luiza imitou os moldes que o terapeuta fez e deixou sob a mesa.

Como principal característica, Luiza se recusa a trabalhar com massas de modelar molhadas, trabalhando somente com as secas.

\section{Mosaico com espuma vinílica acetinada (E.V.A)}

Para as atividades de mosaico, foram utilizados desenhos impressos de diferentes formas e tamanhos em E.V.A. É uma atividade que Luiza gosta bastante, fica sempre muito alegre quando vê o pote de E.V.A. Sempre escolhe figuras relacionadas ao mar, como concha, peixe, caranguejo, Algas, caracol e água viva.

Nas atividades, Luiza fica bastante concentrada, não gosta que ninguém interfira ou chame sua atenção e quando isso acontece fica muito irritada. Durante a atividade demonstra muita tranquilidade e está comumente com um leve sorriso. Luiza tem dificuldade em passar a cola no E.V.A, parece sentir um pouco de nojo por isso sempre pede ajuda do terapeuta. Apesar de ser 5 sessões para variar os tipos de desenhos, a paciente sempre escolhe os mesmos. Quando a psicóloga propõe trocar a figura, a paciente fica irritada.

As sessões foram bem tranquilas, pois a paciente já estava trabalhando há um mês com a arteterapia, conhecia um pouco os instrumentos utilizados. A terapeuta sempre respeitava o tempo da paciente para começar as atividades, assim como seus medos.

\section{Interpretação dos resultados obtidos nas sessões}

Após a apresentação dos trabalhos realizados durante as sessões, será apresentada, a seguir, a interpretação dada aos resultados, por meio da confrontação dos testes e atividades desenvolvidas.

\section{Atividades realizadas com pacientes esquizofrênicos}

Quadro 1: Modalidades arte terapêuticas que podem ser trabalhadas com pacientes esquizofrênicos.

\begin{tabular}{|l|l|}
\hline Desenho Livre & Modelagem \\
\hline Pintura com Lápis de Cor & Mosaico com E.V.A \\
\hline
\end{tabular}

\section{As atividades de desenho livre}

Por meio dos resultados verificou-se que essas atividades deixa a paciente a vontade. Ela demonstra interesse e concentração na realização dos trabalhos, na maior parte do tempo. De acordo com Vasques (2009) no desenho, desenvolve a percepção espacial, a capacidade de observação, a relação entre luz e sombra, coordenação psicomotora e, através da definição da forma delimita, delineia, designa e configura.

Essas atividades contribuem para a melhoria do seu interior da paciente que, conforme Philippini (2009) o desenho faz com que o indivíduo entre em contato com a realidade interna, onde acaba deixando fluir conteúdos que estejam no inconsciente. Nos desenhos dirigidos são feitos a partir de um tema que o Arteterapeuta escolhe, o cliente entra em contato com a realidade, o que desperta emoções. 0 desenho monocromático trabalha as emoções superficiais e o colorido, com as emoções mais profundas.

Sendo dessa forma o desenho traz as mais profundas angústias que o paciente esquizofrênico está sentindo naquele momento, sendo o desenho livre ou dirigido, colorido ou não, a pessoa se projeta no desenho inconscientemente, de certa forma ela está sinalizando para o arteterapeuta o que está acontecendo no seu interno e isso faz-se sentir à vontade para verbalizar. 


\section{As atividades de pintura com lápis de cor}

Na modalidade pintura Christo e Silva (2009) evidenciam que, é uma técnica que permite exercitar novas maneiras de olhar a nós mesmos e a tudo o que nos rodeia. Esse exercício é um dos caminhos, e é um dos mais interessantes, para organizar e transformar sentimentos.

Conforme Coutinho (2008), cada cor do lápis desperta uma sensação, exigindo maior controle de movimentos e coordenação fina, liberando emoções e incentivando a imaginação.

Nessa modalidade, o olhar no que é produzido livremente sobre o suporte oferecido é, muitas vezes, a possibilidade do paciente de olhar para dentro de si mesmo, para algo que até então estava difuso ou oculto de sua consciência ativa. A possibilidade de um fluxo criativo, libera conteúdos inconscientes, promove diversas experimentações emocionais e sensoriais.

\section{Atividade de modelagem}

Na modalidade de modelagem verificou-se que a paciente consegue desenvolver habilidades motoras. Vasques (2009) destaca que por ser tridimensional, é indicado para etapas mais adiantadas do processo arteterapêutico. Relaxa, desenvolve a coordenação motora, a percepção de volume, peso e temperatura e ativa elementos arquetípicos. Após a modelagem, muitas obras têm a possibilidade de ainda serem pintadas e/ou adornadas.

Segundo Urrutigaray (2008), os trabalhos realizados com estes materiais proporcionam uma inesgotável fonte de experimentações e descobertas, desde que estejam associados aos seguintes valores: ordem, paciência e persistência na imaginação e criação.

Dessa forma, o efeito da modelagem atua nas sensações físicas e viscerais, como também no sentimento e cognição do paciente esquizofrênico. Pode ser livre ou dirigida é uma técnica que exige uma canalização de energia adequada, pois parte do nada para a criação de algo concreto através das permissões catarses.

\section{Atividades de mosaico}

Segundo Philipini (2009), o mosaico tem o poder reestruturador dos processos arteterapêuticos e com sua técnica trabalhada de acordo ao público, independentemente das patologias, é possível a promoção de saúde e melhora na convivência social do indivíduo.

A técnica do mosaico para a paciente simbolicamente representa as passagens, como a construção, desconstrução e reconstrução, a busca do que será, do que se há de se formar representa a libertação do indivíduo de acordo com a sua própria capacidade expressiva de ser, se perceber e apropriar-se si mesmo.

A reorganização dos pensamentos de como elaborar-se, organizar-se passa a ser um recomeço seguro e firme de como seguir em frente sem esmorecer-se diante de coisa inteiramente solúveis. Utilizar-se da técnica do mosaico, passa a ter conhecimento da significação das ações manuais realizados: quebrar, rasgar, romper, desestruturar, colar, reorganizar.

0 processo orientado pelos autores, das produções em mosaico, é repleto de significados, uma das características do mosaico é seu caráter irreversível já que, os fragmentos serão colados, fixados e organizados, juntos ou separados sobre um lugar.

\section{Percepções diante do trabalho arteterapêutico}

Morrow (1985) defende que a arteterapia suporta as informações fornecidas juntamente às outras abordagens da terapia primária, desenvolvendo trabalhos de arte terapêutica com o intuito de elucidar conflitos, defesas e para melhorar a comunicação e o relacionamento com o paciente.

As atividades de arteterapia: percepção da pesquisadora

A arte possibilita o autoconhecimento dos pacientes com esquizofrenia e tal autoconhecimento seria empoderado e encorajado pelos profissionais envolvidos nessa abordagem terapêutica.

0 autoconhecimento no âmbito da psiquiatria acontece pelo termo chamado insight, no qual os pacientes se expressam, não tão somente sobre o distúrbio que os afeta, mas também em relação como o distúrbio afeta sua interação com o mundo. 
A terapia, dentro desse contexto, não deve ignorar a existência de distúrbios como a esquizofrenia, mas sim propiciar o aceitamento de tais distúrbios, fomentando a expressividade e a criatividade dos pacientes e o autoconhecimento destes em relação a si próprios, à esquizofrenia e aos efeitos de sua condição no mundo concreto.

A utilização da arteterapia como um dispositivo terapêutico abrange o ideário que contempla a arte como uma possibilidade de libertar o paciente com esquizofrenia não tão somente da exclusão, mas também da alienação provocada pela psicose. A partir da percepção criativa, o paciente sente que a vida é digna de ser vivida, sem provocar o relacionamento de submissão do indivíduo com a realidade externa, de modo a assumir "um sentido profilático na criação de estratégias para uma melhoria na qualidade de vida dos pacientes". (FONSECA et al., 2014, p. 1).

Entende-se que utilização da arte como um dispositivo terapêutico pode produzir benefícios significativos para o tratamento de tais pacientes, sendo sua aplicabilidade promissora no campo da saúde mental, valorizando o autoconhecimento e o relacionamento com os outro, bem como com o mundo que os cerca.

Por isso, é válido explicitar que, a arteterapia deve ser voltada para a promoção da inclusão social dos pacientes com esquizofrenia deve ser pautada na valorização dos pensamentos, sentimentos e emoções, assim, se confirma como um dispositivo terapêutico utilizado com enfoque em tais pacientes, proporcionando-lhes uma melhor qualidade de vida.

\section{As principais atividades e atribuições do psicólogo arteterapeuta}

De acordo com a União Brasileira das Associações de Arteterapia (2017), os Arteterapeutas são profissionais com treinamento tanto em arte como em terapia. Têm conhecimento sobre o desenvolvimento humano e criatividade, teorias psicológicas, práticas clínicas, e sobre o potencial curativo da arte. Utilizam a arte em tratamentos, avaliações e pesquisas, oferecendo consultoria aos profissionais de áreas afins.

Portanto a Arteterapia, facilitada por um arteterapeuta, apoia de maneira eficaz os aspectos pessoais e relacionais. A arteterapia é usada para melhorar a cognição e funções sensoriais e motoras, estimulando a autoestima e a autoconsciência, cultivam a resiliência emocional, promovem insights, melhora as habilidades sociais, reduz ou resolve conflitos e angústias.

Segundo Urrutigaray (2008), o profissional em arteterapia destina-se, assim, como agente facilitador do processo de busca pela "totalidade psicológica", ou realização do Self, ao exercício de estimulação da criação e ao de observar e acompanhar o processo de criação. De maneira que seu "atentar" deve dirigir-se para o que vê e ouve durante a dita execução da obra.

Nesse sentido a Arteterapia é uma profissão integradora de saúde mental e serviços humanos que enriquece a vida dos indivíduos, famílias e comunidades através da criação ativa de arte, processo criativo, teoria psicológica e experiência humana dentro de um relacionamento psicoterapêutico.

Dentro dessa prática terapêutica com Arte, segundo Carvalho (2007) é necessário que esteja o seguinte triângulo que é composto pelo processo expressivo ou pela produção, pelo indivíduo que participa do processo e pelo arteterapeuta.

Figura 1 - Tríade da Arteterapia

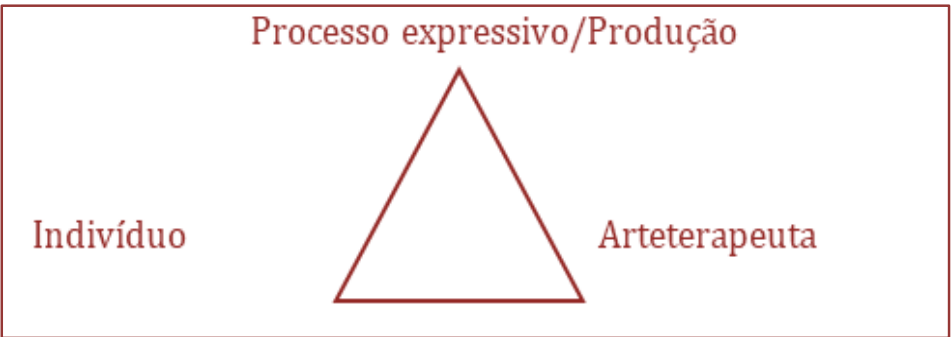

Fonte: Adaptado de Phillipini (2008) 
Sendo para Rodrigues (2010) o papel do arteterapeuta é acompanhar esse processo ajudando o cliente a superar os obstáculos encontrados, construindo, preservando e ampliando possibilidades e oportunidades criativas para que a arte passe a exercer seu efeito terapêutico.

Sem a tríade esse processo não pode ser considerado terapêutico, pois o arteterapeuta deve ajudar e coordenar o cliente em sua aventura de descobrimento de si mesmo, sua atuação é de um mediador entre o processo criativo e o conteúdo que se manifesta na obra de arte.

Barreto e Cunha (2009) consideram a arteterapia uma prática terapêutica que se utiliza de diferentes recursos expressivos, presentes nas diversas linguagens da arte, facilitando aos participantes, um contato com seu próprio universo imaginário e simbólico, possibilitando, dessa forma, novas descobertas e o autoconhecimento.

Trindade (2010) ressalta que para realizar um trabalho em arteterapia, deve-se buscar, nos diferentes recursos artísticos, como: pinturas, colagens e esculturas, etc. no processo criativo do indivíduo as respostas para seus conflitos, angustias e incertezas.

Nesse sentido, o fazer artístico é estimulado em sua totalidade com a criatividade no manuseio dos materiais, expressando seu emocional, e por meio de experiências concretas, deve permitir ao sujeito participante entrar em contato com seu universo imaginário e, a partir desse contato, permitir-lhe elaborar e expressar o seu "acervo" interno de emoções.

\section{CONSIDERAÇÕES FINAIS}

A arteterapia é uma modalidade terapêutica eclética que é utilizada em vários contextos, quer por profissionais de saúde, quer por profissionais da área da educação como forma de compreender os conteúdos emocionais. A arte pode propiciar a percepção do que não foi vivido, o reencontro do que não foi propiciado, e possibilitar está vivência, e mais ainda, de suscitar nas pessoas novas perspectivas com o clareamento e conscientização desses acontecimentos.

Foi possível verificar que a Arteterapia pode ser utilizada no campo da prevenção, recuperação e manutenção da saúde do paciente esquizofrênico. Entretanto esse método pode ser utilizado em campanhas educativas, na recuperação da inserção social, atuando na vida do ser humano desde a sua concepção até a sua morte, respeitando-o na sua totalidade. Pode ser realizada individualmente ou em grupo, em terapias breves e de longa duração, e também no campo da educação.

A utilização da linguagem artística é uma forma de documentar a emoção, tornando o processo mais orgânico, concretizando os dados armazenados internamente, de forma a torná-los visíveis, muitas vezes, a si mesmo e aos outros. A arteterapia e um recurso que proporciona ao sujeito a lidar, ao mesmo tempo, com as emoções e trabalho do fazer, com os significados e os sentimentos resultantes do fazer, e a alegria de se sentir capaz, de ousar, hábil e, conscientemente, as possibilidades, as limitações próprias de cada ser humano.

Ao longo da pesquisa, percebe-se o quanto os materiais podem auxiliar no processo arteterapêutico, cada um remonta a uma sensação, um sentimento, dando a possibilidade do encontro com nosso verdadeiro eu. No reconhecimento e contato com o corpo são relevantes dentro do processo terapêutico, visto que ajudam os pacientes a entrarem em contato com a sua realidade interior.

O paciente quando está em modo criativo, produz imagens que simbolizam uma comunicação catártica, o que se assemelha à ideia da psicologia analítica, que é eleita por muitas instituições para ser a norteadora da especialização em arteterapia.

A arte nas suas diferentes formas de expressão auxilia o ser humano a se comunicar de maneira a ajudá-lo a reorganizar ideias, pensamentos e sentimentos. No processo artístico entramos sutilmente e profundamente no nosso interior, explorando os nossos sentidos e criando uma conexão com o corpo e a mente.

Dentro desse processo, nota-se o trabalho que é feito para acessar as memórias do corpo, bem como o resgate do contato consigo mesmo. Para além do corpo, a arte proporciona o contato com o interior, expandindo a consciência sobre si mesmo ao longo do processo arteterapêutico, e também através da fala o sujeito reesignifica conteúdos conscientes e inconscientes. Assim, a arteterapia pode ser considerada como psicoterapia, uma vez que oferece efetivos resultados quanto ao tratamento do sofrimento psíquico. 


\section{REFERÊNCIAS}

[1] ALMEIDA, Marcos Antonio Bettine de; GUTIERREZ, Gustavo Luis; MARQUES, Renato. Qualidade de vida: definição, conceitos e interfaces com outras áreas. Godoi Trigo. - São Paulo: Escola de Artes, Ciências e Humanidades, 2012.

[2] ALVES, C. R. R; SILVA, M.T.A. A Esquizofrenia e Seu Tratamento Farmacológico. Rev. Estudos de Psicologia, PUC-Campinas, v. 18, p. 12-22, janeiro/abril. 2001. Disponível em: http://www.scielo.br/pdf/estpsi/v18n1/02.pdf. Acesso em: 11 nov. 2019.

[3] AMARAL, V. F. do. Esquizofrenia: da dementia praecox às considerações contemporâneas. Vínculo, São Paulo, v. 11, n. 2, p. 19-30, dez. 2014. Disponível em:

http://pepsic.bvsalud.org/scielo.php?script=sci_arttext\&pid=S1806-

24902014000200004\&lng=pt\&nrm=iso. Acesso em: 11 nov. 2019.

[4] BARRETO, Eliane; CUNHA, Grisa Magda Fátima. Criatividade não tem idade, arteterapia reinventando o envelhecimento no NATIEX. Revista IGT na Rede, v.6, n. 10, 2009, p.24- 28. Disponível em: https://www.igt.psc.br/ojs/include/getdoc.php?id=1316\&article=229\&mode=pdf. Acesso em 25 de abril de 2020

[5] BOAVENTURA, E. Metodologia da pesquisa: monografia, dissertação e tese. São Paulo: Atlas, 2004

[6] BREAKWELL, Glynis M. et al. Métodos de pesquisa em psicologia. Porto Alegre: Artmed, 2010.

[7] CARVALHO, R. L. G. O polimorfismo da arte de sonhar ser. Revista Científica de Arteterapia Cores da Vida, v. 3, n. 3, p. 5-17, 2007.

[8] CHRISTO, Edna Chagas e SILVA, Graça Maria Dias da. Criatividade em Arteterapia. Rio de Janeiro WAK, 2009.

[9] COUTINHO, Vanessa. Arteterapia com idosos: ensaios e relatos. Rio de Janeiro: Wak Ed., 2008

[10] ELKIS, H. A evolução do conceito de esquizofrenia neste século. Rev. Bras.

[11] Psiquiatr., São Paulo, v. 22, supl. 1, p. 23-26, May 2000. Disponível em: http://www.scielo.br/scielo.php?script=sci_arttext\&pid=S1516-44462000000500009\&lng=en\&nrm=iso. Acesso em: 12 nov. 2019.

[12] FONSECA, A. N. et al. Aplicação da Arteterapia com Usuários Esquizofrênicos de um CAPS a Partir da Visão Winnicottiana. VIII EPCC - Encontro Internacional de Produção Científica - Editora Cesumar, Maringá, $22-25 \quad$ out. $2014 . \quad$ Disponível http://www.cesumar.br/prppge/pesquisa/epcc2013/oit_mostra/Cicero_Marcelo_Felix_Junior.pdf Acesso em 13 nov. 2019.

[13] GIL, Antônio Carlos. Como elaborar projetos de pesquisa. 5. ed. São Paulo: Atlas, 2010.

[14] ACOSSIAÇÃO AMERICANA DE PSIQUIATRIA. Manual diagnóstico e estatístico de transtornos mentais: DSM-5/. Trad. Maria Inês Corrêa Nascimento... et al. revisão técnica: Aristides Volpato Cordioli ... [et al.]. 5. ed. Porto Alegre: Artmed, 2014.

[15] MARCONI, Marina de Andrade; LAKATOS, Eva Maria. Metodologia científica. 6 ed. revista e ampliada. São Paulo: Atlas, 2011.

[16] MARTINS, Daniela de Carvalho e Souza. Arte-Terapia e as Potencialidades Simbólicas e Criativas dos Mediadores Artísticos. Dissertação de Mestrado. 2012. Disponível em: http://repositorio.ul.pt/bitstream/10451/10008/2/ULFBA_TES665.pdf. Acessado em 10 de Novembro de 2020

[17] MATOS, A. L. S. D. et al. Revisão Teórica da Esquizofrenia e Implicações Causadas Pela Doença na Vida do Portador e dos Familiares. III Congresso Nacional de Pesquisa em Ciências Sociais Aplicadas - III CONAPE Francisco Beltrão/PR, 01, 02 e 03 de outubro de 2014. Disponível em: https://pt.scribd.com/presentation/385955713/Slide-Adriana. Acesso em: 17 nov. 2019.

[18] MELLA, L. F. B. Insight na psicose: uma análise conceitual. J Bras Psiquiatr. 2011. Disponível em: http://www.scielo.br/pdf/jbpsiq/v60n2/09.pdf. Acesso em: 17 nov. 2019. 
[19] MINAYO, M. C. S. O desafio do conhecimento: Pesquisa qualitativa em saúde. São Paulo: Hucitec, 2013.

[20] MORROW, R. O Uso da Arteterapia em um Paciente com Esquizofrenia Crônica. Jefferson Journal of Psychiatry: vl. 3, n..10, 1985. Disponível em:

[21] https://jdc.jefferson.edu/jeffjpsychiatry/vol3/iss1/10/ Acesso em: 20 jul. 2020.

[22] OLIVEIRA, A. S. R. S. F. Conceitualização Histórica da Esquizofrenia. Mestrado em Medicina apresentado à Universidade do Porto. Porto, 2010. Disponível em: https://repositorioaberto.up.pt/bitstream/10216/50150/2/Conceptualizao\%20Histrica\%20da\%20Esqu izofrenia.pdf. Acesso em: 17 nov. 2019.

[23] PATTERSON, S et al. Arteterapia para pessoas com diagnóstico de esquizofrenia: a visão dos terapeutas sobre o que muda, como e para quem. International Journal of Art Therapy Formerly Inscape v. 16, 2011. Disponível em: https://www.tandfonline.com/doi/abs/10.1080/17454832.2011.604038. Acesso em: 17 nov. 2019.

[24] PHILIPPINI. Ângela (2008). Mas o que é mesmo arteterapia? Disponível em: http://arteterapia.org.br/pdfs/masoque.pdf. Acessado em 18 de novembro de 2019

[25] PRODANOV, Cleber Cristiano; Freitas, Ernani Cesar de. Metodologia do trabalho científico: métodos e técnicas da pesquisa e do trabalho acadêmico. 2. ed. Novo Hamburgo: Feevale, 2013.

[26] REIS, Alice Casanova. Arteterapia: a Arte como Instrumento no Trabalho do Psicólogo. 2014. Disponível em: http://www.scielo.br/pdf/pcp/v34n1/v34n1a11.pdf. Acesso em: 18 de nov. 2019.

[27] RODRIGUES, Carolina Carvalho. Materiais e técnicas sua história e seus valores terapêuticos. Disponível em: http://www.avm.edu.br/docpdf/monografias_publicadas/t206105.pdf. Acessado em 03 de maio de 2020.

[28] ROTELLI, F et al. Desinstitucionalização. São Paulo: Hucitec; 2001. Disponível em: http://www.scielo.br/pdf/pcp/v16n1/02.pdf. Acesso em: 18 nov. 2019.

[29] RUDDY, R.; MILNES, D. Arteterapia para esquizofrenia ou doenças semelhantes à esquizofrenia (Review). Banco de dados Cochrane de revisões sistemáticas 2005. Disponível em: https://www.ncbi.nlm.nih.gov/pubmed/16235338. Acesso em: 18 nov. 2019.

[30] SILVA, T. C. B.; MOYA, C.I.S. Dependência Química e Arteterapia: Revisão Bibliográfica. XVI Encontro Latino Americano de Iniciação Científica e XII Encontro Latino Americano de Pós-Graduação Universidade do Vale do Paraíba, São José dos Campos, 2009. Disponível em: http://www.inicepg.univap.br/cd/INIC_2012/anais/arquivos/0058_0842_01.pdf. Acesso em: 18 nov. 2019.

[31] SILVEIRA, N. Imagens do inconsciente. Rio de Janeiro: Alhambra, 1981.

[32] TRINDADE, Nancy Rabello de Barros. A arteterapia como uma das possibilidades no processo de crescimento $\quad$ pessoal. $2010 . \quad$ Disponível em: http://www.fatea.br/seer/index.php/angulo/article/viewArticle/226. Acessado em 10 de abril de 2020.

[33] UNIÃO BRASILEIRA DAS ASSOCIAÇÕES DE ARTETERAPIA. A arteterapia. 2017. Disponível em: www.ubaat.com.br. Acesso em: 22 abril 2020

[34] URRUTIGARAY, M. C. Arteterapia - A transformação pessoal pelas imagens. Rio de Janeiro: Waak Editora, 2008.

[35] VASCONCELOS, E. A; GIGLIO, J. S. Estudos de Psicologia. Introdução da arte na psicoterapia: enfoque clínico e hospitalar. (2000) Disponível em:

http://repositorio.unicamp.br/bitstream/REPOSIP/40264/1/S0103-166X2007000300009.pdf. Acesso em: 18 de nov. 2019.

[36] VASQUES, Márcia Camargo Penteado Corrêa Fernandes. A arteterapia como instrumento de promoção humana na saúde mental. 2009. 87 f. Dissertação (mestrado) - Universidade Estadual Paulista, Faculdade de Medicina de Botucatu, 2009. Disponível em: http://hdl.handle.net/11449/98472. Acesso em: 10 de nov. 2020.

[37] YIN, R. K. Estudo de caso: planejamento e métodos. 2. ed. Porto Alegre: Bookman, 2001. 
